Historic, Archive Document

Do not assume content reflects current scientific knowledge, policies, or practices. 


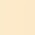




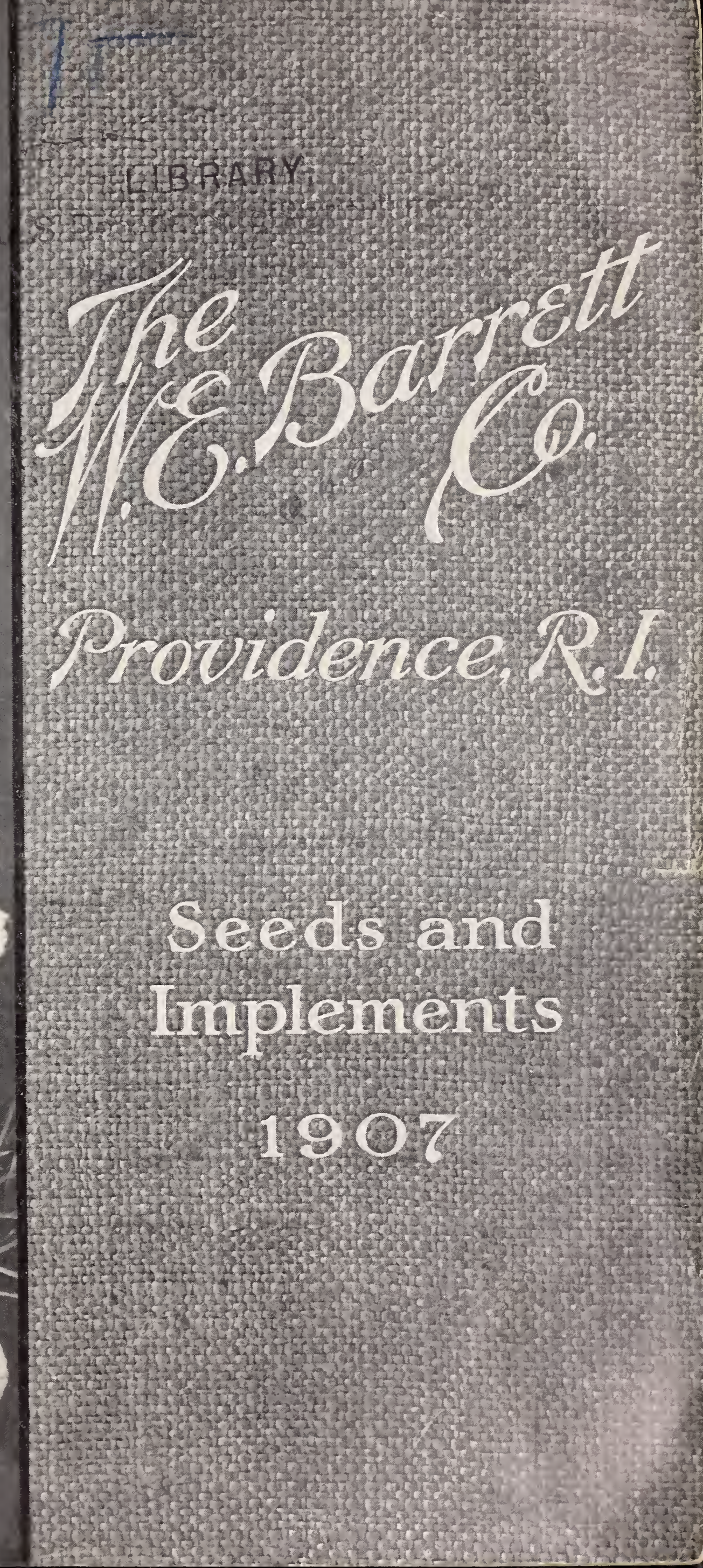




\section{THIS TABLE WILL BE FOUND CONVENIENT FOR REFERENCE "KEEP IT HANDY" \\ QUANTITY OF SEED USUALLY SOWN TO THE ACRE}

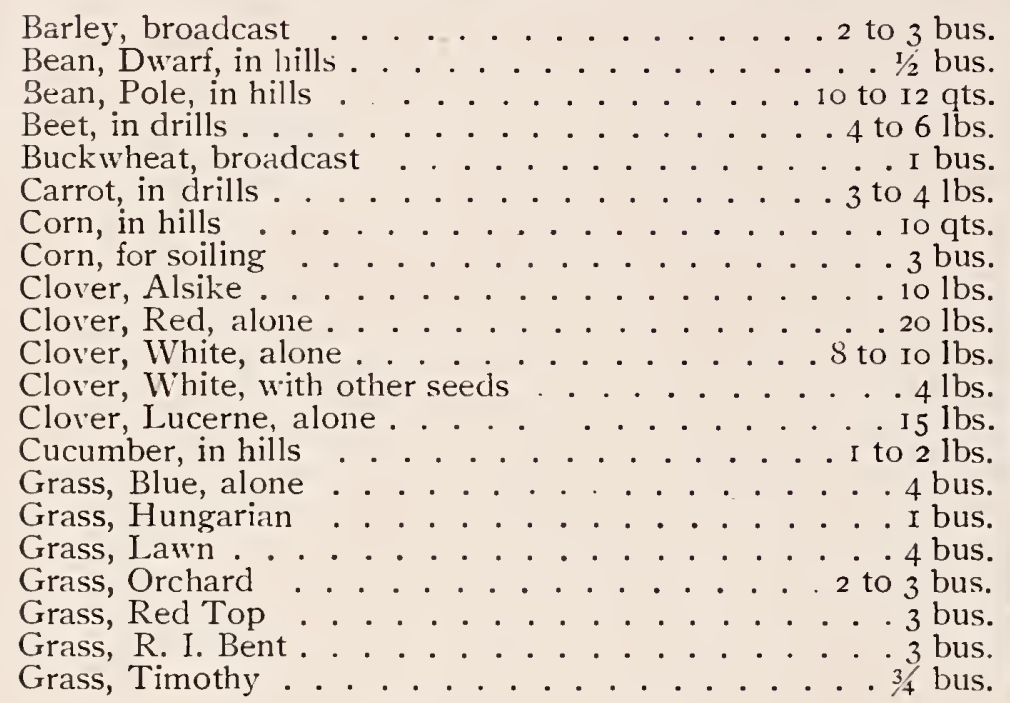

Millet. $1 / 2$ to I bus. Mustard ................ 10 to I6 qts.

Oats, broadiast . . . . 2 to 3 bus.

Onion, in drills . . . . . . . 4 to 6 lbs.

Parsnip, in drills $\ldots . .4 .4$ to 5 lbs.

Pea, Early, in drils . . . . . . . I I $1 / 2$ bus.

Pea, Narrowfat, in drills . . . . . . $1 / 2$ bus.

Pea, broadcast . . . . . . .

Radish, in drills . . . . . . . . 6 to 8 lbs.

Radish, broadcast . . . . . . . Io lbs.

Rye, broadcast . . . . . . . i to $\mathrm{I}^{1 / 2}$ bus.

Salsify . . . . . . . . . 6 to 8 lbs.

Spinach, in drills . . . . . $25 \mathrm{lbs}$

Turnip, in drills $\ldots \ldots \ldots \ldots \ldots \ldots 1 / 2 \mathrm{lb}$.

Turnip, broadcast $\ldots \ldots \ldots$ I lb.

Vetch, broadcast . . . . . . . 2 to 3 bus.

Wheat, in drills . . . . . . . 3 bus.

Wheat, broadcast $\ldots \ldots \ldots$ I $1 \frac{1}{2}$ to 2 bus.

Clover, Timothy, Red Top together, for one acre: Io lbs. Clover, $1 / 2$ bus. Timothy, I bus. Red Top (chaff), or 8 lbs. clean seed.

\section{BUG DEATH}

This insecticide and Plant-Food combined has been on the market for eight years, and its s.iles hive shown a large increase each year. We can say to our customers that we give Bug Death our fullest endorsement. W'hile the first cost to kill the bugs

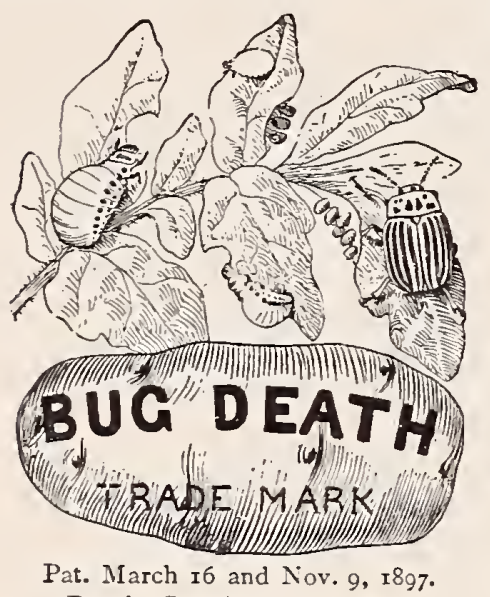

Pat, in Canada Nov, 2, I8g7. on an acre of potatoes is rather more than that of the arsenical insecticides, the results at harresting time are entirely satisfactory, and where practical tests liave been made the extra yield of marketable potatoes has more than paid the entire expense. It is non-poisonous, which makes it perfectly safe to use on all plants and vines.

Very beneficial results are obtained by using Bordeaux Mixture in connection with Bug Death, and they can be mixed and sprayed on the rines at the same time, with any of the spraying machines on the market for that purpose. Bug Death prevents blight.

\section{FOR SPRAYING FRUIT TREES}

Bug Death is perfectly harmless to use and apply, and Bug Death will protect your fruit trees. It has been thoroughly tested by the large peach-and apple-growers of Naine, Nova Scotia and Massachusetts.

Use Bug Death for your fruit trees It kill : the insect pests, protects the 1rees, promotes their vigorous growth, gives freedom to the bees, and insures quality and quantity of fruit. No other agent can do this. Bug Death must be the reliance of the fruit-grower, who, by spraving, seeks after perfect fruit.

\section{PRICE-LIST}

One-pound package. .

. So i5 Twelve and one-lialf pound package... . sr m

Three pound package
Five-pound package

\begin{tabular}{l|l}
35 & One hundred pound package. \\
50 & Dickey Duster, for applying dry
\end{tabular}

\section{Directions for Spraying One Acre of Potatoes with Bug Death}

Thoroughly mix $121 / 2$ to 25 pounds of Bug Death with sufficient water; the amount of water to use is governed by the kind of sprayer it is applied with, also by size and condition of the vine. Be particular to spray the entire vine thoroughly, using any of the sprayers that are on the market. Better results are obtained when the machine used has a first-class agitating device, as it is of paramount importance that the solution used be uniform in strength when it is applied to the foliage.

If desired, Bordeaux mixture may be used in connection with Bug Death.

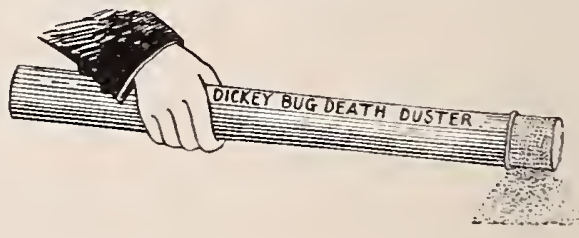

VEGETABLE PLANTS AND ROOTS

\section{CABBAGE PLANTS \\ CELERY PLANTS}

Early Jersey Wakefield . \$O IO \$O 60

Henderson's Summer

Drumhead Savoy

Stone-Mason

$\begin{array}{ll}\text { I0 } & 60 \\ \text { I0 } & 60 \\ \text { I0 } & 60\end{array}$

\section{CAULIFLOWER PLANTS}

Henderson's Snowball . $\$ 020 \quad \$ 125$

STRAWBERRY PLANTS

All Standard Varieties . . \$ \$100 $\$ 500$
Paris Golden ...... \$o I5

White Plume

Giant Pascal

I 5 cts. per bunch, $\$$ I. 50 per doz.

\section{EGGPLANT}

New York Improved . . Do $\$ 50 \$ 300$

\section{CHIVES}

LETTUCE PLANTS

All varieties ...... \$0 15 \$0 75

PEPPER PLANTS

Doz. $\quad 100$

Bullnose ........ \$o 20 \$I 25

Ruby King . . . . . 20 I 25

Squash ......... 20 I 25

TOMATO PLANTS

Acme . . . . . . . \$o $20 \$ 125$

Dwarf Champion .... 20 I 25

Stone ....... 20 I 25 


\section{FIFTY-NINTH ANNUAL CATALOGUE}

\section{Seeds and Implements}

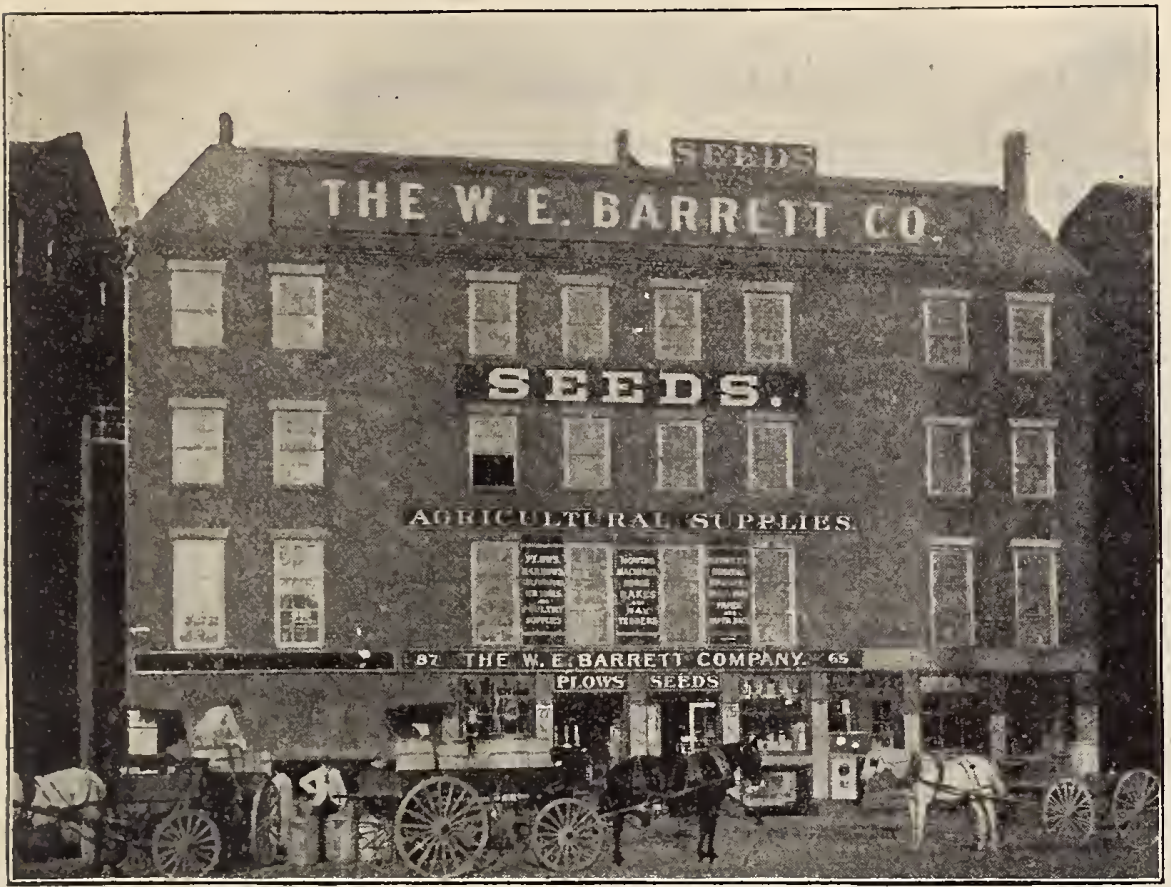

N presenting this, our Annual Cata-
logue, we extend greeting to our cus-
tomers and our thanks for their patronage the past year. Never were we in a position to supply better stocks of seeds than in this coming season. The past season produced, with some exceptions, a fair crop of seeds of good quality, the shortages being confined to Peas, Beets, Radishes and Onions. In some sections the Onion seed crop was an entire failure.

As to Prices, you will find quite a reduction from last year. We shall make no advance over these prices as long as our present stock lasts, but if we have to replenish at higher rates, we claim the right to advance without notice.

Important.-Order early; in so doing you will avoid the delay that is liable to occur in the spring rush.

For Testing.- To those desiring for their own satisfaction to test any of our stock as to germination, we shall be pleased to furnish samples free.

Special Market-Gardeners' List.-For Market-Gardeners and others using a large quantity of seed-free upon application.

Seeds by Mail. - We send all seeds ordered at packet, ounce and quarter-pound rates free by mail, postage paid. To the prices of seeds quoted by the pound, and to those of Beans,. Peas, Corn, etc., add for postage at the rate of 8 cents per pound, or i 5 cents per quart.

Remittances may be made at our risk by Draft, Post Office Money Order, Express Company's Money Order, or Registered Letter.

All Vegetable Seeds sold at the uniform price of 5 cents per packet.

Remember we make no charge for cartage.-Cloth bags for packing are charged only at cost, and are returnable at same rates if sound and in good condition.

WARRANTIES.-While we exercise great care to have all seeds pure, reliable and true to name, our seeds are sold without any warranty, expressed or implied, and without any responsibility in respect to crop. If our seeds are not accepted on these terms, they must be returned at once.

Seeds of the best quality will often fail through improper treatment. More failures result from disregard of the conditions necessary to germination than from the quality of the seeds used.

A proper temperature, sufficient moisture, and the soil in good condition, are all of great inportance. Seeds also differ as to temperature required for germination. Peas, Beets and Radishes start rapidly at a temperature of $45^{\circ}$, Tine seeds, Beans and other seeds of the same class require at least $60^{\circ}$; for this reason many seeds fail by too early planting. Besides, even after germination the young plants are liable to accidents; a sudden drop in the temperature or a strong drying wind may destroy them altogether. Thus the conditions are as important as the vitality of the seed.

\section{THE W. E. BARRETT CO.}

PROVIDENCE, RHODE ISLAND 


\section{Lawns and Their Management}

To insure a really fine lawn, there are several requisites : a good depth of rich soil, properly drained, and free from boulders immediately below the surface; a liberal dressing of thoroughly decayed manure (ten or twelve cords per acre); nicety of grading in the levels and slopes; a firm, smooth suriace upon which to sow the seed; and a sufficient quantity of the very best lawn grass seed, suited to the situation. The latter item is of prime importance. Boulders below the surface will, during the heat of summer, cause unsightly dry spots in an otherwise beautiful lawn; all such should be removed. A rich soil of good depth, and liberally fertilized, will maintain a fine greensward permanently, needing only an occasional top-dressing. Fresh strawy manure should never be used in making a lawn; when decaying, it is liable to allow uneven settling of the soil. Make a smooth surface with harrow and rake, and use a roller to make it firm and even, before sowing the seed. After sowing, cover the seed well by raking it in, and again use the roller to finish the work.

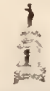

\section{The "Capitol" Lawn Seed}

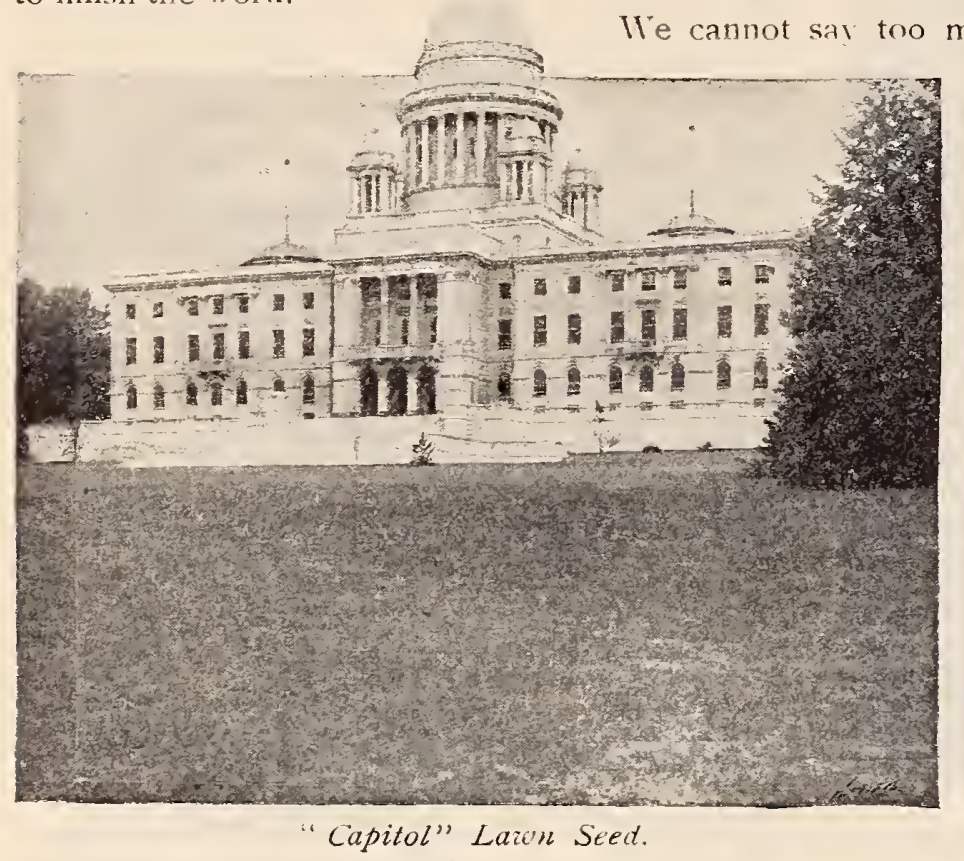

uch in regard to this mixture. The grounds around the "State House" are a forcible recommendation to its quality and reliability. Sown down late in the spring, in two months' time it showed a sward equal to the best year-old lawn in the city. This mixture contains only clean seeds of the very best quality, entirely free from weeds or any foreign matter.

For lawn-tennis courts, croquet grounds, etc., the "Capitol" mixture gives a fine, smooth, velvety sward a few weeks after sowing. Weight about 30 pounds to the bushel. Sow three bushels to the acre.

The best recommendation for the "Capitol" Lawn Seed is our sales, which increased 300 per cent over last season. Qt. 25 cts., 2 qts. 50 cts., 4 qts. 85 cts., 8 qts. $\$$ I. 5 o, bus. $\$ 5$.

\section{Park Lawn Seed}

This mixture we have prepared and sold for years, and it has given, and still gives, good results. It ranks with the average good Lawn Seed generally offered by seedsmen.

The mixture is composed of pure seeds, free from weeds. Sow four bushels to the acre. Qt. $15 \mathrm{cts}$., pk. $\$$, bus. $\$ 3.5$ o.

\section{Special Mixtures}

We have through the season quite a number of orders from landscape gardeners, contractors, cemetery managers, etc., of Special Mixtures, sometimes in Ioo bushel lots; on such orders, we will make special low prices, according to quantity wanted.

\section{For Shady Places}

In the lawn we have a special mixture, composed of grasses of habit and growth adapted for such situations. In a great many instances, where lawns are very much shaded, and not well drained, the ground becomes sour. In such cases, slaked lime will be found of much benefit, say one bushel to the thousand square feet. Qt. $25 \mathrm{cts}$., pk. $\$$ I.50, bus. $\$ 5$.

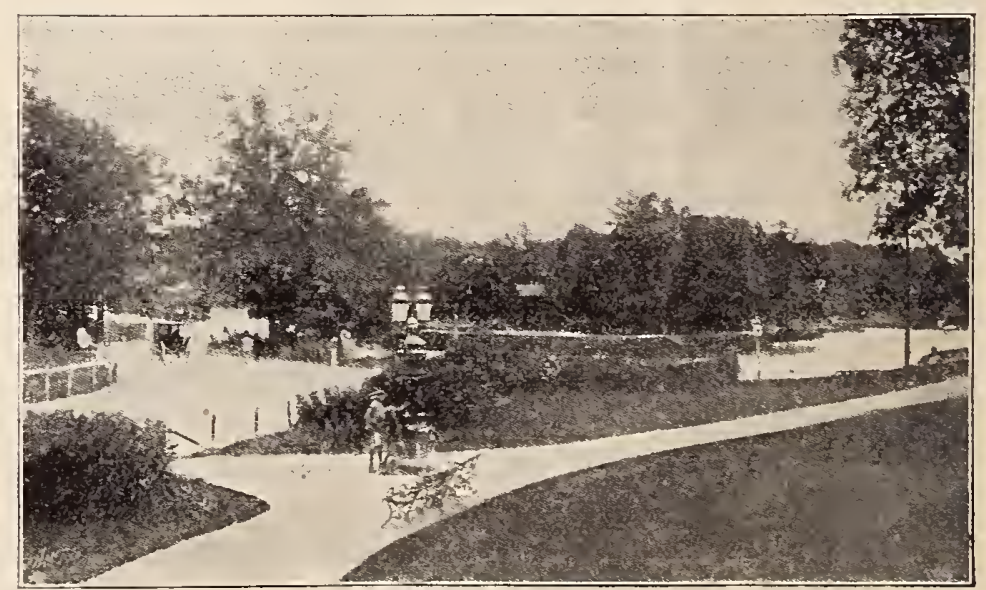

Park Law'n Seed.

\section{Seeds for Golf Links and Putting=Greens}

A specially prepared mixture for golf links. Bus. \$2.50.

A combination of grasses for sowing on putting-greens, to produce a dense, close sward. Qt. 25 cts., pk. $\$ \mathrm{I} .5 \mathrm{O}$, bus. $\$ 5$.

RE=SEEDING. To re-seed lawns that have become worn out by neglect or other causes, and where it is not desirable to renew by plowing up, they may be greatly benefited by running a light harrow over, if the surface is large, or by a sharp steel rake for smaller spots. After which Lawn Seed should be sown over the surface, raking in about half the quantity advised for a new lawn, then rolled or beaten down firmly; but if weeds and rank-growing grasses have got possession of the lawn it had better be plowed under and sown afresh. 


\section{A Fer Norelties and Specialties}

\section{SUTTON'S EXCELSIOR PEA}

Since the introduction of Nott's Excelsior, which is today probably the most popular dwarf wrinkled sort in America, we have seen no Pea that is so great an advance in this class as Sutton's Excelsior. Similar in habit of growth to Nott's Excelsior, but bearing very large broad pods filled with large peas, tender and of most delicious flavor. Its great merit lies in the fact that in this we have an early dwarf wrinkled Pea in the front rank for earliness, with much larger and handsomer pods than any dwarf early wrinkled Pea yet introduced. It takes the place in this class so acceptably filled by Stratagem and Telephone in later sorts, and by Gradus in the extra-early class, and is bound to be in great demand when fully known; of first-class merit, and we most confidently recommend it. Pod long, broad, straight, pale green, wrinkled. Height $\mathbf{2} 2$ inches. Qt. 35 cts., $\mathrm{I} / 2 \mathrm{pk}$. $\$ \mathrm{I} .25$, bus. $\$ 7$.

\section{NEW DWARF STONE TOMATO}

Another splendid new variety from Livingston, This is what he says of it: "The same sort of Tomato as Dwarf Champion, but the vine is of stronger growth, and the fruit is double the size. It is equally early; is equally prolific, and, averaging double the size, will bear double the crop. The shape of the fruit is perfect ; it is very solid, ripens very evenly and is of excellent quality. The vines admit of planting half as near again as the common sorts." Oz. $30 \mathrm{cts}$, , 1/ lb. $\$ \mathrm{I}, \mathrm{lb}$. $\$ 3$.

\section{THE DAVIS PERFECT CUCUMBER}

A sure moner-maker for those engaged in growing Cucumbers under glass for profit, as well as for truck gardeners to grow out-of-doors. In color, a dark glossy green; shape, slim and symmetrical, with an average length of to to 12 inches. They never grow pussy, and hold their color until nearly ripe. Another strong point is its splendid shipping qualities. It is as early as the earliest strain of IThite Spine, and outyields anything yet introduced. Oz. 30 cts., I/4 lb. $\$ \mathrm{I}, \mathrm{lb} . \$ 3$.

\section{BLACK BEAUTY EGGPLANT}

This is a very handsome early and prolific variety introduced two years ago. It is a decided improvement over the New York Improved. While the fruit is as large as that variety, it matures much earlier and is of a deeper and richer color. The plants are of robust growth and are very prolific. Being earlier than the New York Improxed, much larger crops are produced before frost. We offer some very choice seed and we are sure it will be found equal, if not superior, to any seed offered. $\mathrm{O}$ \% $40 \mathrm{cts}$., $1 / 4 \mathrm{lb}$. $\$ 1.25, \mathrm{lb}$. $\$ 4.50$.

\section{PARIS GOLDEN SELF $=B L A N C H I N G$ CELERY Market-Cardeners' Stock}

This is the main-crop Celery in this vicinity, and, recognizing the fact of so much depending upon the quality of the seed, we use the utmost care in procuring our stock, which is grown for us by the most reliable grower in Europe, and thoroughly tested, before sent out, as to purity and germination, and we recommend it with every confidence. Oz. $40 \mathrm{cts}$, $1 / 4 \mathrm{lb} . \$ 1.25, \mathrm{lb} . \$ 5$.

\section{SPARKS' EARLIANA TOMATO}

The earliest smooth red Tomato grown. Shipping qualities fine; flavor excellent. Already the leading variety for first crop. Oz. 40 cts., $1 / 1 / \mathrm{lb}$. $\$$ I.25, lb. $\$ 4$.

\section{CABBAGE LETTUCE, "MAY KING"}

This choice variety has proved itself very valuable as an early outdoor Lettuce. It is not affected by cold or wet weather, grow's very quickly, producing splendid large heads earlier than any other variety, and will stand a long time before running to seed. In flaxor it is unexcelled. Oz. 20c, 1/4lb. 5oc., lb. \$I.5o.

\section{NEAPOLITAN LARGE EARLY PEPPER}

The earliest of all large, mild red Peppers, and the most productive

The strong, vigorous plants grow 2 feet higl by 18 inches across. The skin and flesh are bright red, they are thickmeated, sweet, very mild and unusually productive. A very desirable variety for the market-gardener. Oz. $30 \mathrm{cts}$, $1 / 1 / \mathrm{lb}$. $\$ \mathrm{I}$, lb. $\$ 3.50$.

\section{NEW SWEET CORN, PEEP O'DAY}

Two points of this remarkable Corn are its earliness and sweetness. It is also wonderfully productive, the stalks bearing from two to fixe ears each. It is very dwarf, which admits its being planted close together. This is a very desirable variety for the family garden. Qt. $25 \mathrm{cts}$., $1 / 2 \mathrm{pk}$. 75 cts., bus. $\$ 4.50$.

\section{GOLDEN BANTAM SWEET CORN}

Extremely hardy and very early. Stalks grow about 4 feet high. Ears from 5 to 6 inches in length; the grains when ready for use are a bright golden yellow. The flavor is rich and sugary, "the sweetest of all." Qt. 25 cts., I $/ 2 \mathrm{pk}$. $75 \mathrm{cts}$., bus. $\$ 4.50$.

\section{THE VOLGA CABBAGE}

This new Cabbage is a grand acquisition. Heads round as a ball, sometimes a foot in diameter; a splendid variety for fall and winter market. It is a first-class keeper and splits less than other Drumheads. Planted as late as the first week in July, it will give one of the finest crops of Cabbage ever seen. $\mathrm{O} z$. 30 cts., $1 / 4$ lb. $\$ 1,1 b . \$ 3$.

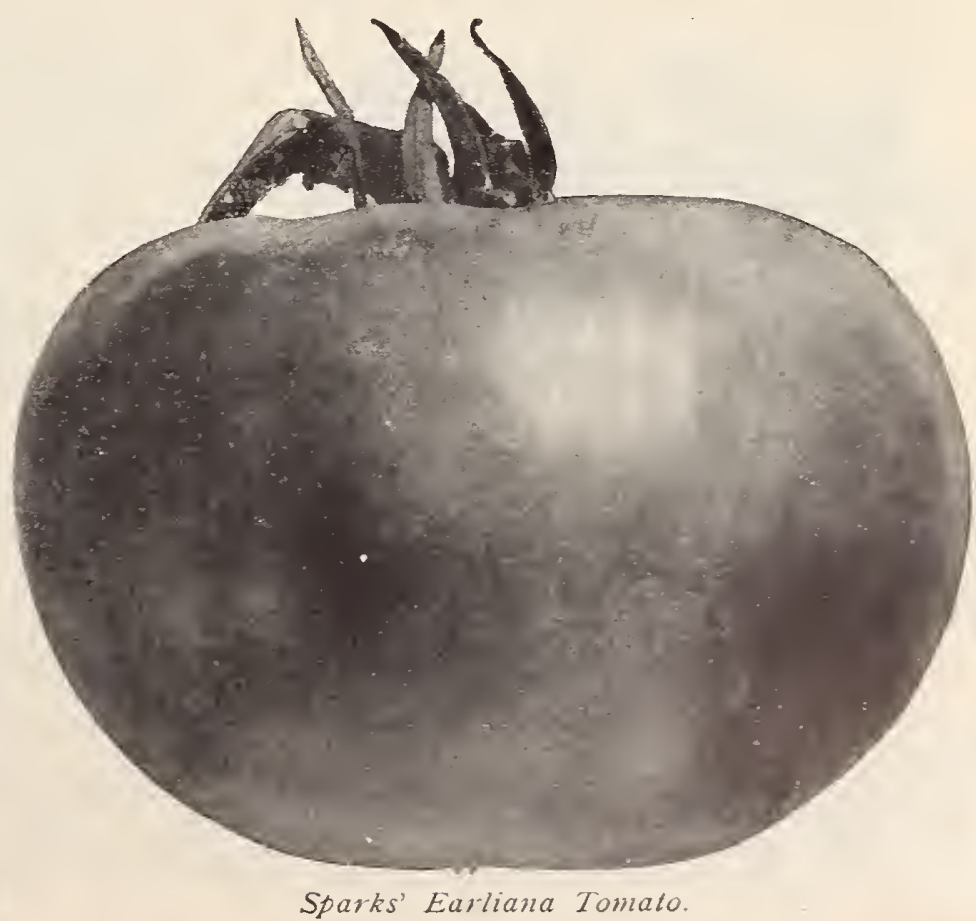




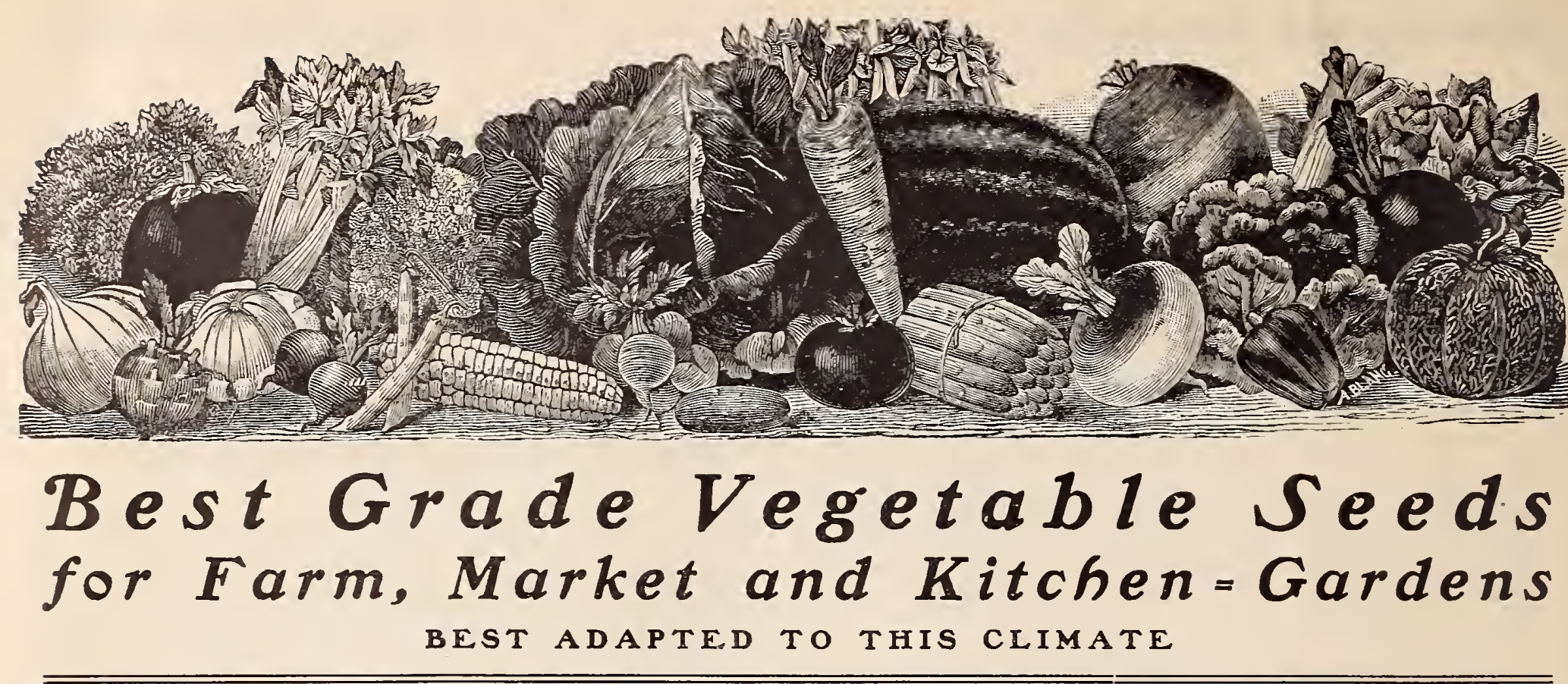

HOW SEEDS ARE SENT. POSTAGE PREPAID. We deliver free, at Catalogue prices, to any post office in the United States, all seeds

SEEDS SOLD BY MEASURE, when to be sent by mail, require, in addition to Catalogue prices, 8 cts. per pint and 15 cts. per quart for Peas and Beans, and $5 \mathrm{cts}$. per pint and $8 \mathrm{cts}$. per quart for Corn. To prices of seeds sold by the pound, add postage at the rate of $8 \mathrm{cts}$. per pound.

LIBERAL PREMIUMS. Remember that these cash discounts refer only to prices of seeds sold in packets, the order in all cases.

On 51 orders, select Seeds amounting to $\$ 1.25$. On $\$ 2$ orders, select Seeds amounting to $\$ 2.50$. On $\$ 3$ orders, select Seeds amounting to $\$ 3.75$

FOR PREMIUMS ON FLOWER SEEDS, SEE FIRST PAGE FLOWER SEEDS.

All Vegetable Seeds sold at the uniform price of $5 \mathrm{cts}$. per packet

\title{
ASPARAGUS (eparget)
}

This is one of the first and finest spring relishes which come to the table from the garden, and it really requires very little trouble in cultivation, since a bed once properly made and planted will last for years. The soil for the bed can hardly be made too rich, and the fertilizer should be well trenched-in to the depth of 2 feet or more. The roots should be planted as early in spring as the ground can be prepared, setting them a foot apart in rows 3 or 4 feet apart, with the crowns from 4 to 6 inches below the surface of the bed. Asparagus seed may be sown directly in the permanent bed and the plants thinned as they grow; or it may drill, and produce about 300 plants. Fair crops may be expected the third year.

Palmetto. Earlier than Colossal, with stalks as fine in size and quality, and more even and regular in growth. Oz. Io cts., 1/41b. 25 cts., lb. 75 cts.

Colossal. Widely cultivated; very large, deep green, tender stalks of good flavor. The roots are
vigorous and productive. Oz. IO cts., 1/41b. 20 cts.,

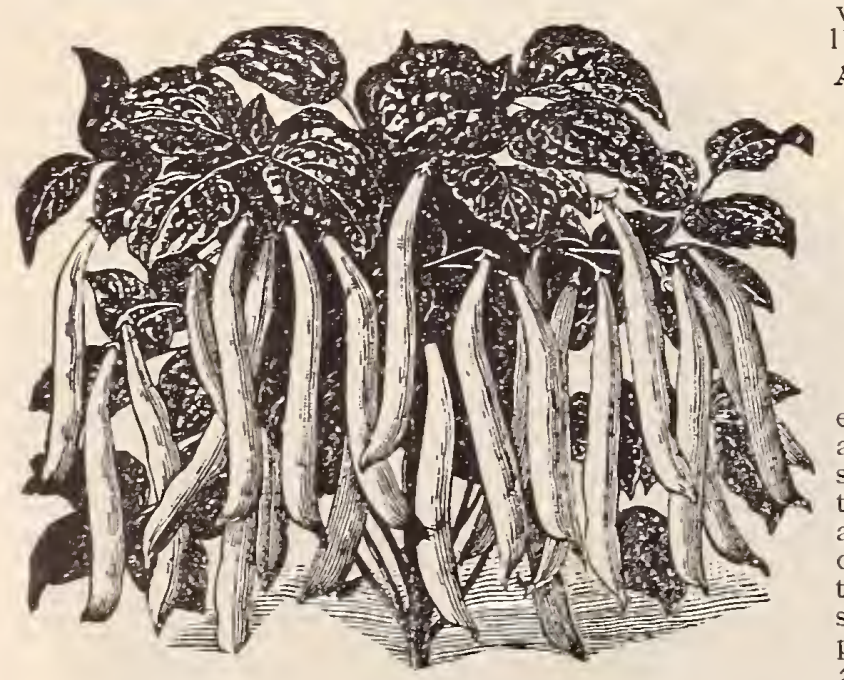
vigorous and productive. Oz. Io
lb. 50 cts.

ASPARAGUS ROOTS- ${ }_{100} 1,000$ Palmetto. 2 years old .... \$o $75 \$ 600$ Colossal. 2 years old...... 75600

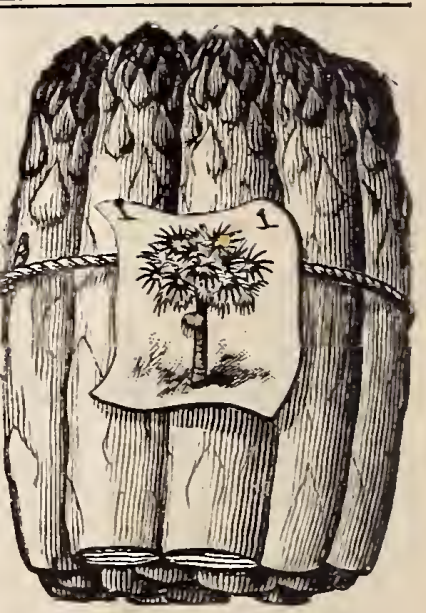

Barr's Mammoth. 2 years old... $75 \quad 600$

Palmetto Asparagus.

\section{BEANS, DWARF or BUSH}

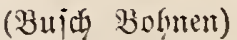

Beans are among our most valuable farinaceous foods, and form a market staple everywhere. The seeds should not be planted before the ground becomes light and warm, in favorable seasons usually about the first of May. Bush Limas should not be planted so early as other sorts, as Limas are particularly sensitive to cold and damp. The soil should be rich and mellow, and the seeds scattered about 3 inches apart in drills from 3 to $3^{1 / 2}$ feet apart, and covered about 2 inches deep. The plants will need frequent hoeing, but should never be cultivated when the leaves are wet with dew or rain, as this will cause them to rust. Successive sowings made at intervals of about two weeks until the middle of July will give a plentiful supply of beans all season. One quart of seed will sow too feet of drill ; 2 bushels will sow an acre.

Golden Wax Bean.

For Beans sent by mail, add postage at the rate of $8 \mathrm{cts}$, per pint, $15 \mathrm{cts}$. per quart

WAX, or YELLOW=PODDED BEANS

Golden Wax. (Original strain.) A very popular variety, more generally cultivated than any other sort, and in our trials it has proved itself superior in all respects to the so-called Improved Golden Wax. Finer pods, better color and more tender. The vines are with purplish red. Qt. 30 cts., $1 / 2$ pk. 85 cts., bus. $\$ 6$. 
WAX BEANS, continued

Currie's Rust-Proof Wax. A valuable Bean, from the fact that it see us to be "rust-proof," after having been tested for several years with other Beans which rusted badly. Q $: 30 \mathrm{cts}$., $1 / 2 \mathrm{pk}$. $85 \mathrm{cts}$., bus. $\$ 6$.

New Round Pod Kidney Wax. New, superior. One of the best round-podded Wax Beans in cultivation. Qt. $30 \mathrm{cts}, 1 / 2 \mathrm{pk} .85 \mathrm{cts}$, bus. $\$ 6$.

Davis Kidney Wax. Podslong, between flat and round, clear waxy in color; seeds pure white; early as Golden WVax. Flaror and eating qualities excellent. Beans pure white, and excellent for canners' use. Qt. 30 cts., I/2 pk. \$r, bus. $\$ 6.50$.

Golden-Eyed Wax. As remarkable for its beauty of pod and vine and manner of growth as for its freedom from rust and blight. The plant is rapid and vigorous in growth, yielding an early and abundant crop of beautiful golden yellow pods. Qt. 25 cts., $1 / 2$ pk. 85 cts., bus. $\$ 5.50$.

Wardwell's Kidney Wax. A most excellent early variety, widely grown and deservedly popular. Pods creamy yellow, long. broad, flat, brittle and stringless; beans kidney-shaped, white shaded with purplish brown; vines productive, strong and upright in growth. Qt. 30 cts., $1 / 2 \mathrm{pk}$. \$I, bus. $\$ 6.50$

\section{GREEN=PODDED BUSH BEANS}

Improved Red Valentine. The leading, and by far the most generally grown green-podded Bush Bean. Hardy and vigorous; uprivht in growth, pods being well held up from the ground; early and remarkably uniform in ripening, making it very desirable for market-gardeners, as a large proportion of the pods can be secured at one picking; pods round, thick and solid, tender, and of fine flavor. This strain of Valentine is earlier than any we have ever tested, and more uniform in ripening, with almost entire absence of flat pods. Qt. 25 cts., $1 / 2 \mathrm{pk} .75 \mathrm{cts}$., bus. $\$ 4$.

Long Yellow SIx Weeks. Valuable on account of its extra earliness and productiveness. The pods are long and flat, and of good quality as long as they are tender. Qt. 25 cts., $1 / 2$ pk. 65 cts., bus. $\$ 4$.

Bountiful. Pods long, flat, good quality, and entirely stringless; early and prolific. Qt. $25 \mathrm{cts}$., $1 / 2$ pk. $75 \mathrm{cts}$., bus. $\$ 4$.

Boston Favorlte, or Goddard. Large, handsome red pods, tender and fine for use as snaps; seeds very large and of delicious flavor, whether used green or dry. The bushes yield heavy crops. Qt. $25 \mathrm{c}$., $1 / 2 \mathrm{pk} .75 \mathrm{c}$., bus. $\$ 4.50$.

Burpee's Stringless Green Pod. Extremely early, hardy and productive; pods handsome and of fine quality. Ot. $30 \mathrm{Oc}, \mathrm{t} / 2 \mathrm{pk} .85 \mathrm{c}$, bus. $\$ 5.50$.

Ruby Dwarf Morticultural. Furnishes green-shelled beans of fine quality; seeds yellowish white, with red splashes; large, oval, plump, easily shelled. Qt. 25 cts., 1/2 pk. 75 cts., bus. $\$ 5$

Low's Champion. Very productive, with stringless, large, green, flat pods. Excellent either as a string or shell Bean. Qt. $25 \mathrm{cts}$., $1 / 2 \mathrm{pk}$. $75 \mathrm{cts}$, bus. $\$ 5$.

\section{BUSH LIMA BEANS}

Fine crops of delicious Limas are now grown without poles

Burpee's Bush Lima. This Bean has become immensely popular. The plants come true from seed, and the dwarf habit has become well fixed. They grow into splendid branching, circular buslies I 8 to 20 inches high and 2 or 3 feet across. The strong constitution of the plant is shown in its stout, thick stalks and large, deep green, leathery leaves, as

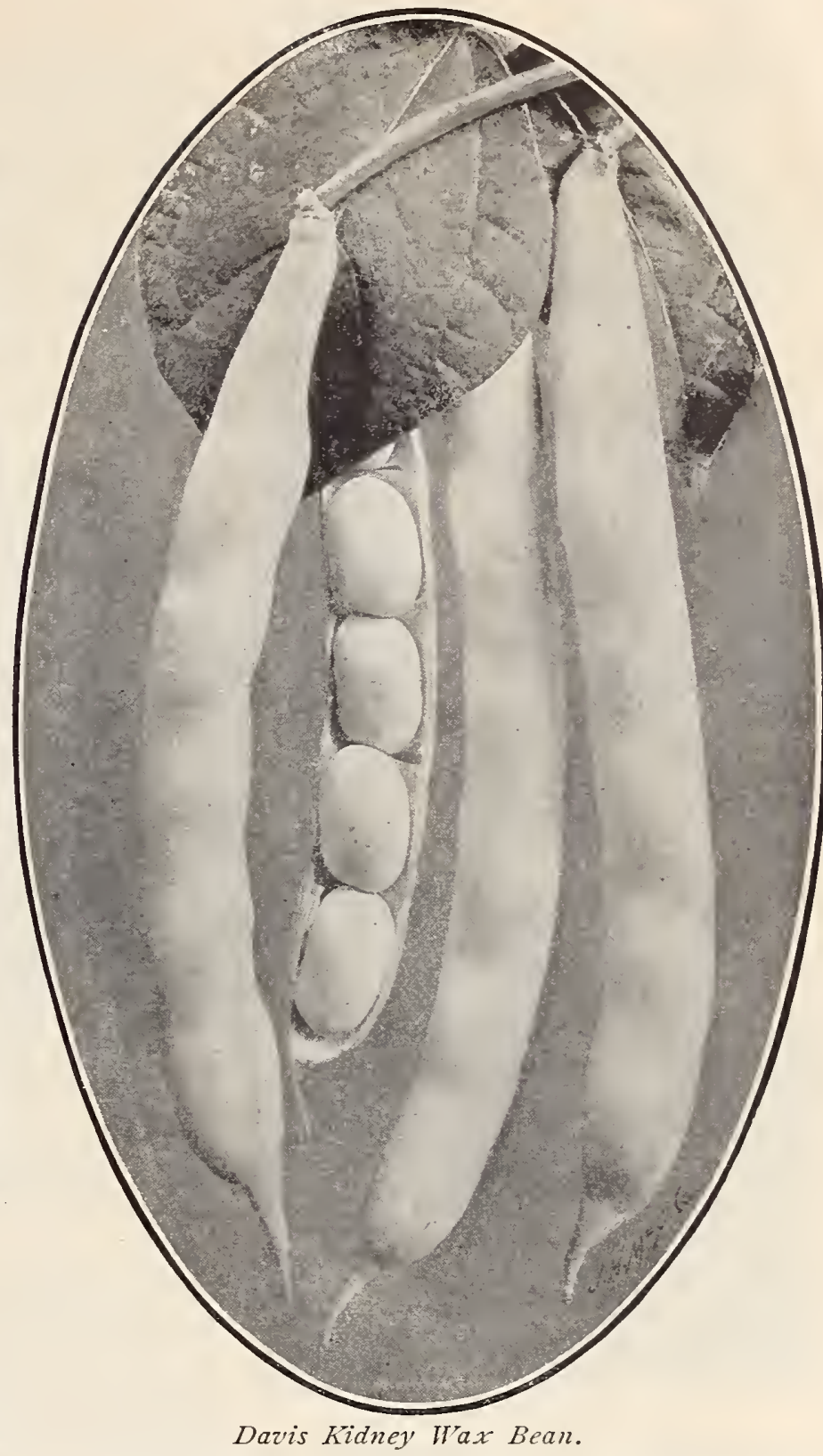

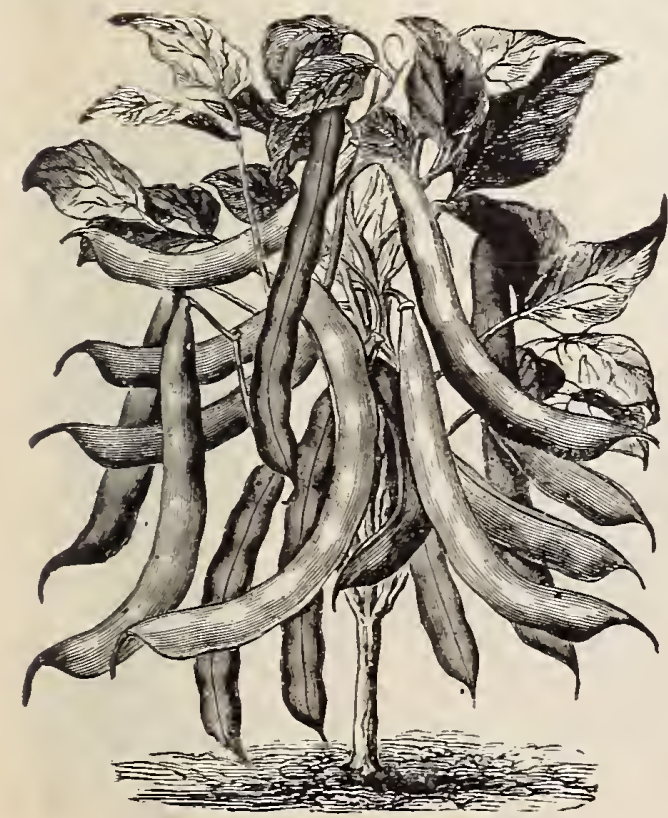

Improved Red Valentine Bean.

much as in its enormous yield of thick, broed, handsome pods, which are as large and well filled as those of the Pole Limas; as many as 200 pods have been counted on a single plant. Identical in size and flavor with the Pole Limas, having the same rich, buttery taste, and preferred by many to that variety. Qt. $30 \mathrm{cts}$., T/2 pk. \$I, bus. \$7.

Dreer's, or Kumerle's Bush LIma. This variety is of strong, bushy habit, and produces its pods in great abundance. The beans are crowded thickly in the pods, and the seeds are thick, sweet and succulent. Qt. $30 \mathrm{cts}$., 1/2pk. \$I, bus. \$7.

Honderson's Bush Lima. Two weeks earlier than the Pole Limas, and the bushes bear long and continuously; the beans are of the small Sieva type. Qt. 30c., $1 / 2 \mathrm{pk}$. $\$ \mathrm{I}$, bus. $\$ 7$.

\section{POLE, or RUNNING BEANS (Stangen $B$ ofnen)}

Pole Beans are not so hardy as the Bush sorts, and should be planted several week later, when danger from frost is over. Plant the seeds in slightly raised hills 3 to 4 feet apart, four or five seeds to the hill. The Limas are especially tender, and the rule for late outside planting with them is rigid. Painstaking cultivators, who are usually the most successful, plant them eye downward after setting stout poles for every hill. quart of Limas will plant about Ioo hills; a quart of the small sorts about 200 .

Golden Cluster. Productive, early plump, tender, yellow pods from 6 to 8 inches long, of fine flavor; remains fit for use a long time; vines bear continuously. Qt. 35 cts., 1/2pk. \$1.25.

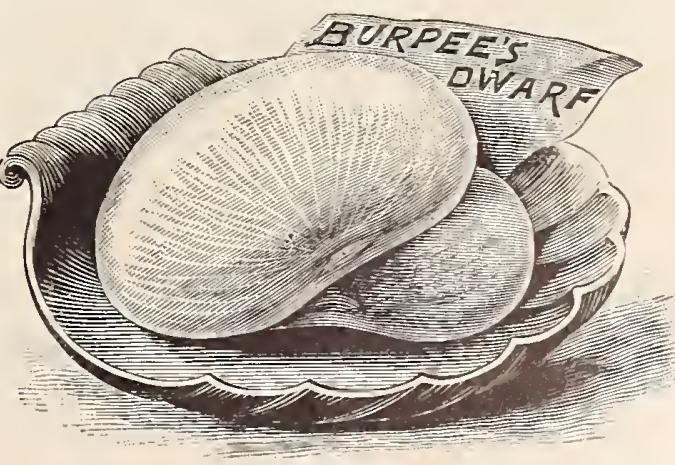




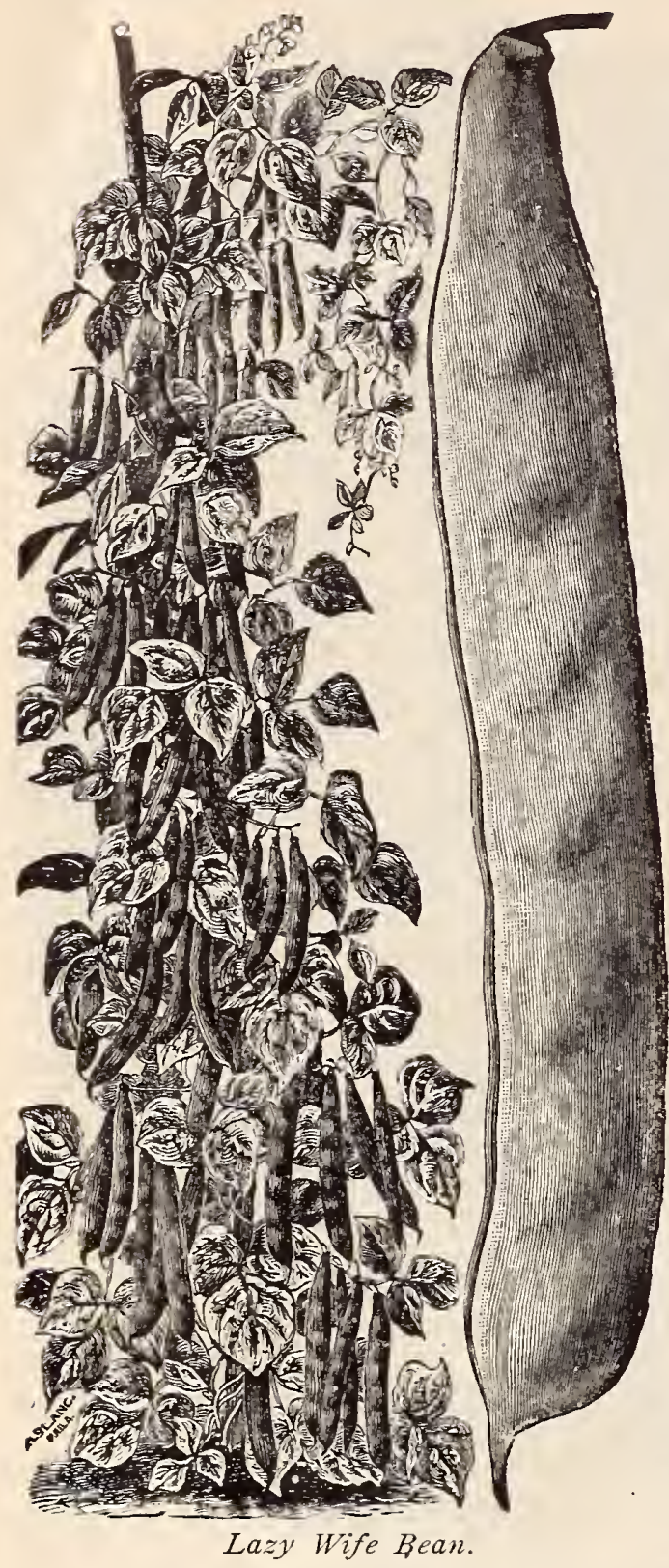

POLE, or RUNNING BEANS, continued

Lazy Wife. Popular and productive; pods green, 4 to 6 inches long, broad, thick, fleshy and entirely stringless; of rich, tender quality. Each one contains from 6 to 8 plump, round, white beans, which are excellent for winter use; late in maturing, and one of the best of this type of Beans. Qt. 30 cts., $1 / 2 \mathrm{pk} . \$ \mathrm{I}$.

Old Homestead, or Improved Kentucky Wonder. Excellent, very productive; pods a silvery green color, large, and entirely stringless. Qt. $30 \mathrm{cts}, 1 / 2 \mathrm{pk}$. \$I, bus. $\$ 6.50$.

Worcester Pole, or Mammoth CarmIne Horticultural. Beans and pods much larger than the ordinary Horticultural. Qt. $30 \mathrm{cts}$., $1 / 2$ pk. 85 cts., bus. $\$ 6$.

Hortlcultural, or Cranberry. Good as a shell Bean, either green or dry; beans large, spotted with red; of good flavor; very productive. Qt. 30 cts., 1/2 pk. 85 cts., bus. $\$ 550$.

Scarlet Runner. Very ornamentaI, free climber, with bright scariet flowers. Ot. 35 cts., $1 / 2$ pk. $\$$ I.I.

White Runner. Large, white flowers; often planted with the scarlet variety; the effect is very fine. Qt. 35 cts., $1 / 2 \mathrm{pk}$. $\$$ I.I 5 .

\title{
POLE LIMA BEANS
}

KIng of the Garden. An improvement on the Large

Lima, with large beans and pods and more productive habit.

Golden Carmine Horticultural is the Bean for Market-Gardeners.

bear continuously until frost ; only two vines should be allowed to a hill. Qt. 30 cts., 1/2pk. $\$ 1$, bus. \$7.

Extra-Early LIma. A standard variety; the beans are large and buttery in flavor. Qt. 30 cts., $1 / 2 \mathrm{pk}$. $\$ 1$, bus. $\$ 7$.

Dreer's Improved LIma. Early and productive; beans thick and rounded, tender .and good. Qt. 30 cts., $1 / 2$ pk. $\$$ I, bus. $\$ 7$.

\section{BRUSSELS SPROUTS}

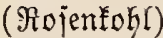

This is a very delicate-flavored species of cabbage, with small, solid, tender heads clustered thickly along the main stem. When properly cooked and seasoned they are delicious, melting away in the mouth like fine cauliflower. The seed should be sown in April or May, and the plants cultivated like cabbage; they are very hardy, aind the heads are improved by frost. In some sections where good cabbage cannot be grown, these Sprouts succeed admirably. All gardeners should give them a trial; they should be a favorite vegetable. An ounce of seed will produce 3,000 plants.

Dwarf Improved. Plants of this variety are dwarf, with small, solid, tender heads, growing very close together along the stem. A standard sort of exceptional flavor when touched by frost. Oz. 25 cts., 1/41b. 65 cts., 1 b. $\$ 2$.

\section{The Best Garden Beets}

(ङalatrüben)

Sweet and juicy Beet roots, when young and tender, form very tempting salads and pickles. The soil best suited to the Beet is a deep and light, rich, sandy loam. For very parly crops, the seed of Crosby, or some similar sort, is sown in hotbeds, and the seedlings are transplanted to the open ground as soon as it is warm enough. For main crop or early Beets, the seed is sown outside, as soon as the soil is in good condition, in drills from I2 to 24 inches apart, and covered about one inch deep; the plants are thinned to stand Io inches apart in the rows. For winter crops, sow seed in July, in drills as for early Beets. An ounce of seed will sow 50 feet of drill; 5 to 6 pounds an acre.

CROSB Y IMPROVED. This strain is an improvement on the Egyptian Blood Turnip. The flesh is fine-grained, sweet and tender. the color is deep, rich red, Oz. Io cts, $\mathrm{I} / 1 \mathrm{~b}, 25 \mathrm{cts} .1 \mathrm{~b} .75 \mathrm{cts}$

Detroit Dark Red. Early maturing, and of splendid shape and color. Tops small, upright growing, so that the rows may be close together; leaf-stems and veins dark red, blade green ; roots globular or ovoid, peculiarly smooth; color of skin dark blood-red; flesh bright red, zoned with a lighter shade, very crisp, tender and sweet, and remaining so for a long time. Oz. Ioc., 1/41b. 20c., 1b. 6oc.

Crlmson Globe. This handsome variety is especially adapted for light soils; very early; its round shape and rich color make it a desirable market variety. Oz. Io cts., $1 / 41$ b. 25 cts., 1 b. 60 cts

Dewing's.Blood Turnlp. One of the best main-crop and late sorts. The roots are long. round and smooth, with blood-red flesh. Oz. Io cts., I/4lb. 27 cts., 1b. $50 \mathrm{cts}$.

Edmand's Blood Turnip. Round, smooth, and uniform in shape, and seldom growing too large; unusually sweet. Oz. Io cts., I/4lb. 20 cts., 1 b. 60 cts.

ECLIPSE. Roots are globe-shaped, deep red, with sweet, fine-grained flesh, which remains tender a long time. Oz. IOc., I/1 1b. 20c., lb. 6oc.

Arllngton Favorite. A variety closely resembling Dewing's, as originally introduced. Of medium size and dark, rich color; excellent. Oz. Ioc., $1 / 1 \mathrm{lb}$. 20c., 1b. 6oc. Long Smooth Blood. Half-long, deep red roots; flesh firm, juicy and tender Oz. Io cts., $1 / 4 \mathrm{~b}$. 20 cts., $1 \mathrm{~b}$. $60 \mathrm{cts}$.

Swiss Chard Sea-Kale Beet. Grown for its tender, succulent tops, which are pre pared for the table like spinach or asparagus. Oz. Io cts., $1 / 1 \mathrm{lb} .25 \mathrm{cts}$., $1 \mathrm{~b} .75 \mathrm{cts}$.

\section{BROCCOLI (Evrofientohi)}

Requires the same treatment as cauliflower. The heads are tender, white and delicate in flavor. An ounce of seed will produce about 3,000 plants.

White Cape. Heads creamy white, of medium size, compact ; sure to form, and delicate in flavor. Oz. 30 cts.

Purple cape. Like the above, except that the heads are larger and of a purplish

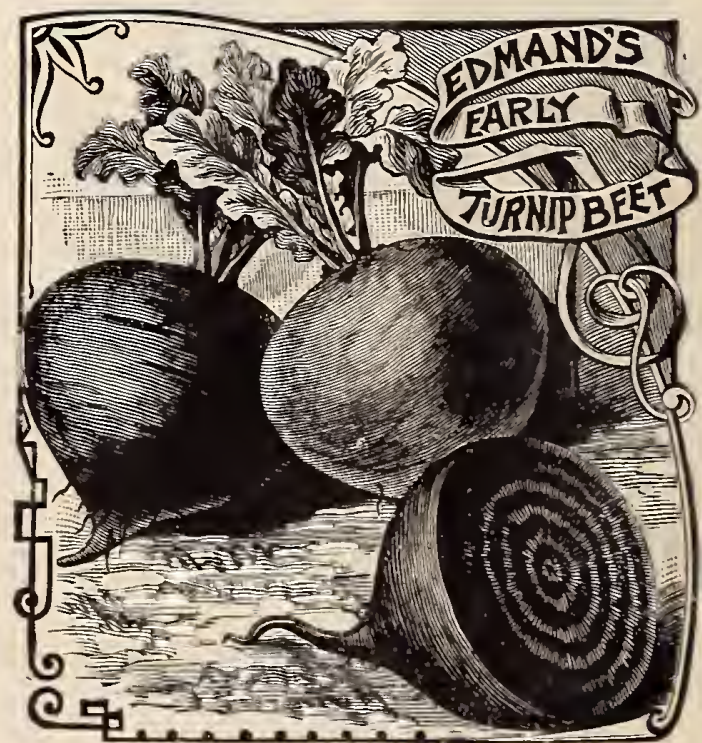
color. Oz 30 cts. 


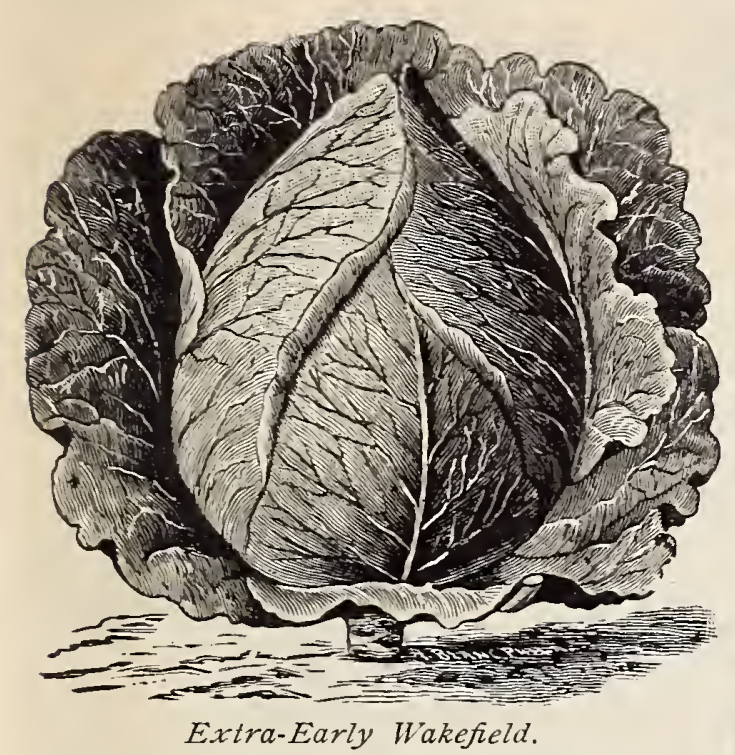

Extra-Early Jersey Wakefield. The best early variety of Cabbage. Heads of medium size, pyramidal, pointed, firm and solid, with few outside leaves; they are very uniform in shape, size and time of maturing, and are of good quality. Oz. 25 cts., $1 / 4$ lb. 65 cts., 1b. $\$ 2$.

Large Jersey Wakefield, or Charleston. A selection from the above, and ten days later, with heads rounder and twice as large. A fine variety, and worthy of general cultivation. $\mathrm{Oz}$. $25 \mathrm{cts}$., $1 / 1 \mathrm{lb} .65 \mathrm{cts}$., lb. $\$ 2$.

'Henderson's Succession. About a week later than Early Summer, with heads mucl larger. Good for early or late use. Oz. $25 \mathrm{cts}$., $1 / 4 ! \mathrm{b} .65 \mathrm{cts} ., 1 \mathrm{~b} . \$ 2$.

Henderson's Ear1y Summer. than the IVakefield, and twice its size. The beac and stand a long while after maturity without bursting. The outer leaves of the plant grow close and upright, so that they may be planted close together and thus save space. Oz. 20 cts., $1 / 41 \mathrm{~b} .65 \mathrm{cts}$., 1b. $\$ 2$.

Early Winnigstadt. Conical or "sugar loaf" heads of fair size. It is one of the best summer Cabbages, and if sown too late, good for fall. Oz. 20 cts., I/41b. 5o cts., Ib. Si.5o.

All-Seasons, or Vandergaw. Noted for its superior quality and delicacy of flavor. Almost as early as Henderson's Early Summer; heads larger and quite thick through; good for early and late crops. Oz. $25 \mathrm{cts}$, T/4 lb. $75 \mathrm{cts}$., lb. $\$ 2$.

Select Large Late Flat Dutch. An excellent keeping variety; the old standby for main crops and still more extensively grown for main crops than any other sort. Heads large, broad, roundish, flat, solid and of good quality. A fine sort. Oz. 20 cts., $1 / 41 \mathrm{~b} .65$ cts., $1 \mathrm{~b}$. $\$ 1.75$.'

\section{Extra Select Cabbage Seed}

Cabbage is one of the gardener's most important crops, the value of which depends 作 and late crops. In the mild climate of the southern states, where the plants can endure the winter, they may be set out in rows in fall. Seed sown in hotbed or greenhouse Io. Set them 3 or 4 inches apart each way, and as soon as they become well established, remove the glass for part of the day, to harden them for final transplanting into the open grasing the exposure daily until April Io or 20, when the final transplanting may be made. Plants for this early crop need stand no farther apart than $1 / 2 \times 2$ feet. (n)

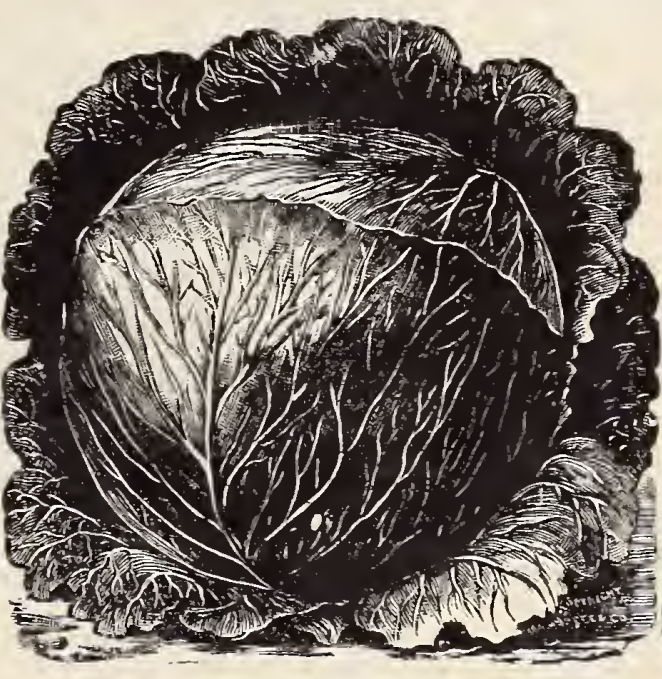
planting must be done on a dry, hot day the roots should be "puddled"-kept in buckets of soil and water beside each planter - until they are placed in the ground; this will prevent drying out.

To insure large, solid heads of Cabbage, the soil must be plowed deep and made very rich. The plants need thorough cultivation, and the insects which molest them should be kept in check with remedies which seem most efficacious in the locality. Crops of Cabbage should not be grown for a number of years in the same ground, on account of club-root.

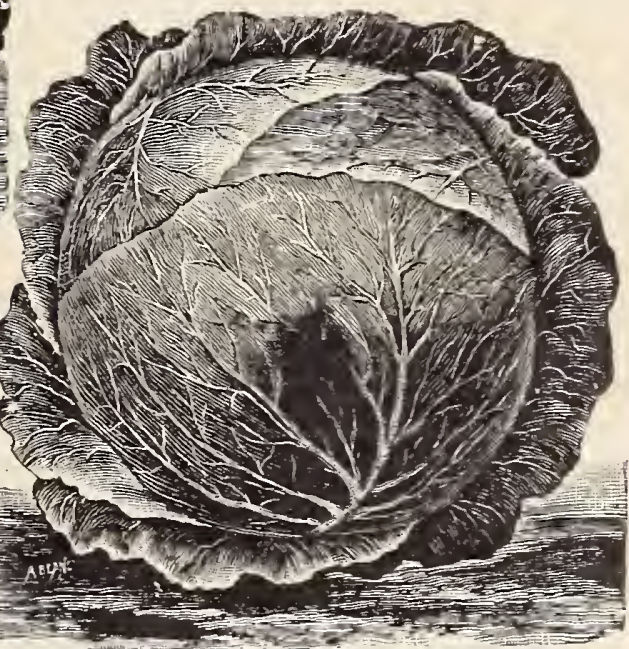

Henderson's Early Summer.

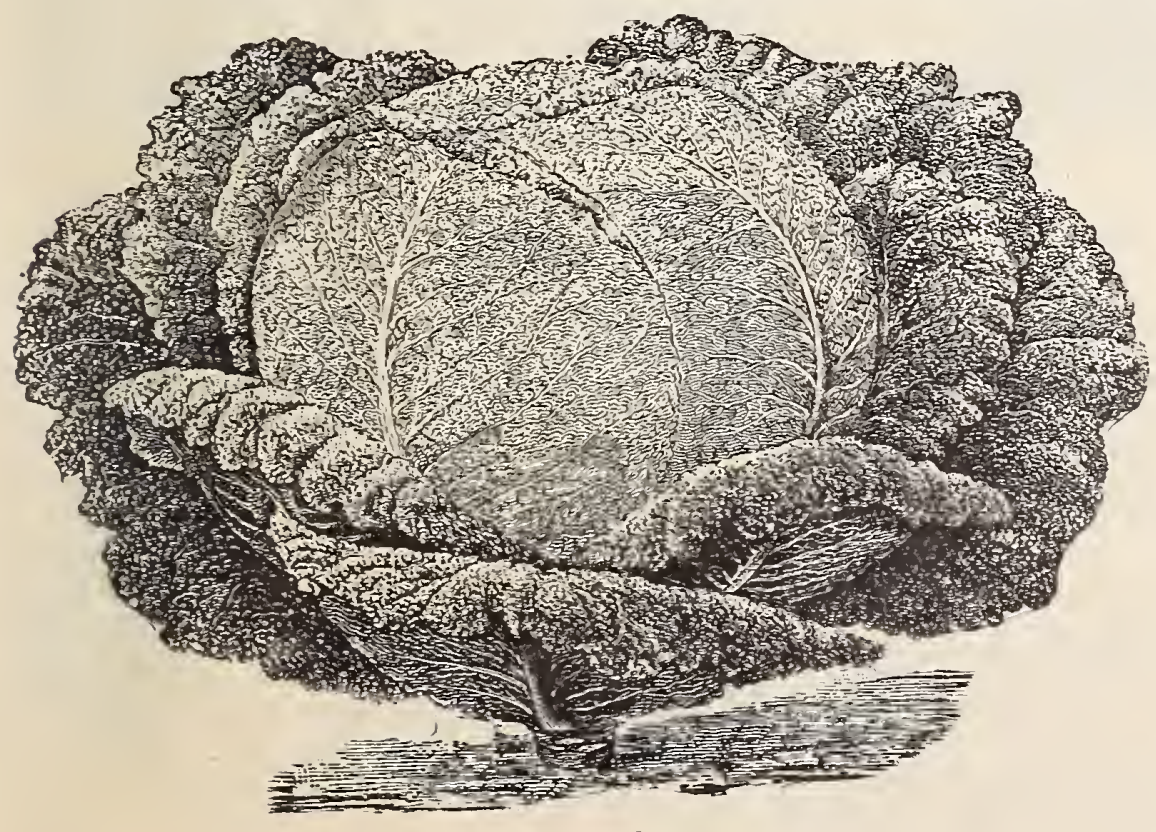

Drumhead Savoy.

Danish Ballhead. Heads are thick, round, of medium size and about as hard as a rock. The stump averages longer than with our native sorts. For best results for late marketing, plant about ten days earlie: than the common Drumhead on land liberally manured. Oz. 25 cts, $1 / 4 \mathrm{lb}, 75 \mathrm{cts}, \mathrm{lb}, \$ 2.50$

Improved American Drumhead Saroy. The best Cabbage of this fine class. Heads large, solid, with finely curled, close wrinkled leaves, of cauliflower flayor; a good-keeping, fine winter Cabbage. Oz. 25 cts., $1 / 4 \mathrm{lb} .65$ cts., $1 \mathrm{~b} . \$ 2$.

Red Dutch. This variety is widely grown fot pickling. $\mathrm{Oz} 25 \mathrm{cts} ., 1 / 4 \mathrm{lb} .65 \mathrm{cts} ., 1 \mathrm{~b} . \$ 2$.

Warren's Stone-Mason. A greatly improved type of Stone-MIason, being earlier, rounder and mere solid. $\mathrm{Oz}$ $25 \mathrm{cts}$., $1 / 4 \mathrm{lb} .55 \mathrm{cts}$., $1 \mathrm{~b}$. $\$ 2$

OUR CABBAGE SEED IS ALL

NEW ENGLAND GROWN

\section{CHICORY}

\section{(Etctorie)}

The seed should be sown in early spring, in good, mellow soil, and in drills half an inch deep.

Large-Rooted Magdeburg, or Coffee. The roots form the Chicory of commerce; the leaves when blanched make an excellent salad. Oz. I5 cts., I/4lb. $35 \mathrm{cts}$., 1b. \$I. 


\section{Cauliflower}

(Blumenfohl)

Fine cream-white heads of Cauliflower seldom fail to bring a good price in any narket. A proper succession of varieties affords this very popular and desirable vegetable through a long period of the year.

Henderson's Early Snowball. This is the earliest and most popular variety in cultivation and is largely grown everywhere, both for forcing and early crops outside. The plants are dwarf and sure heading; of fine, delicate flavor. $1 / 4 \mathrm{oz} .65 \mathrm{cts} ., \mathrm{oz} . \$ 2$.

Extra-Early Erfurt. We believe ours to be the finest strain of Erfurt ever offered. The plants may be depended upon to form large, firm, white heads very early. The variety compares very favorably with Early Snowball. $\quad 1 / 40 z .65$ cts., oz. $\$ 2$.

Danish Giant. Finest Danish-grown seed. Al most as early as the Snowball, with larger heads. Very reliable header. A feature of it, the leares curling over the head, does away with tying to blanch, and gives it the name of Self-protecting Caulifower. $1 / 4 \mathrm{Oz}$. 75 cts., oz. \$2.50.

HOW TO GROW FINE CAULIFLOWER. The general outlines of culture for Cauliflower and cabbage are essentially the same, but to the former extra care given in the way of supplying fertilizers and moisture well repays the gardener. Sow the seeds for early and late crops as directed for cabbage but do not set the early plants in the field too soon, for if too much stunted by severe frosts they begin to form heads before they are strong enough to develop them well. Plants which have not headed before winter sets in may be stored in a cool cellar or coldframe, and will form heads there without any further attention. A deep, loamy soil, with a substratum of moisture during dry weather, is most suitable for the Cauliflower. Market-gardeners find this one of their most profitable crops, and amateurs who undertake its culture find it easy; but it is a crop in which carelessness or neglect will interfere with the best results. An ounce of seed will produce about 3,000 plants.
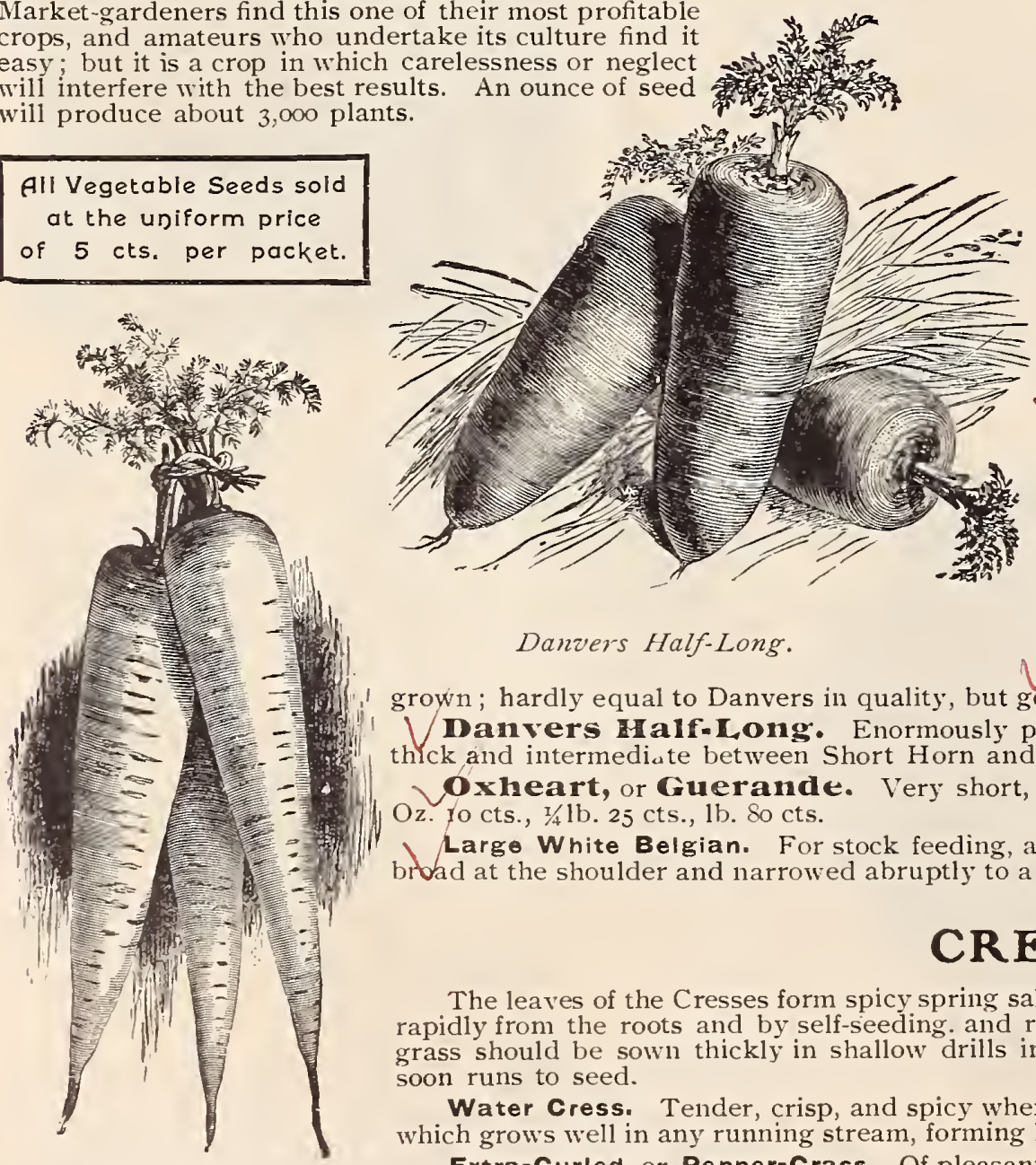

Danvers Half-Long.

Henderson's Early Snowball Cauliflower.

\section{Carrots}

\section{(Mïhren)}

Carrots succeed best on light, sandy loam, which, preferably, should have been well fertilized the previous year, as fresh manure often causes the roots to grow pronged and misshapen. Sow the seed as early in spring as the ground can be prepared, firming the soil down orer it. If sown late it should be soaked in tepid water, then mixed with plaster or sifted coal ashes, and sown on freshly prepared soil. Quick germination and rapid growth are necessary. An ounce of seed will sow Ioo feet of drill; four pounds will sow an acre.

Early Scarlet Morn. Best for forcing and early cutdoor crops; can be grown in shallow soil, and requires no thinning if sparingly sown, as the roots are used when young for cooking. They are about 3 inches long rand of very good quality. Oz. Io cts., $\mathrm{t} / \mathrm{lb}$. $25 \mathrm{cts}$., 1b. so cts.

Chantenay. Handsome roots, broad shouldered, and smooth and more uniform than in the Danrers. Of superior flavor. Oz. Io cts., $1 / 41 \mathrm{~b}$. $25 \mathrm{cts}, 1 \mathrm{~b}$. $80 \mathrm{cts}$.

Improved Long Orange. Extensively grown; hardly equal to Danvers in quality, but good, and heavy in yield. $\mathrm{Oz}$. Io cts , 1/41b. $20 \mathrm{cts}$., $1 \mathrm{~b} .60 \mathrm{cts}$ Danvers Half-Long. Enormously productive; adapted to all soils. The roots are smooth, thlck and intermediate between Short Horn and Long Orange in form. Oz $10 \mathrm{cts}$., 1/41b. $25 \mathrm{cts}, 1 \mathrm{~b}$. $80 \mathrm{cts}$.

Oxheart, or Guerande. Very short, smooth and thick, and well adapted to shallow soils. Oz. 10 cts., $1 / 4$ lb. 25 cts., lb. 80 cts.

Large White Belgian. For stock feeding, and especially suited to shallow soils. Roots white-fleshed, broad at the shoulder and narrowed abruptly to a point. Oz. 1o cts., $1 / 1 \mathrm{lb}$. $20 \mathrm{cts}$., $1 \mathrm{~b} .60 \mathrm{cts}$.

\section{CRESS (Irefie)}

The leaves of the Cresses form spicy spring salads, and are also used for garnishing. The plants increase rapidly from the roots and by self-seeding. and require little care after they become established. Peppergrass should be sown thickly in shallow drills in early spring, and at intervals for continual supply, as it soon runs to seed.

Water Cress. Tender, crisp, and spicy when young. Plant of prostrate habit. A perennial aquatic, which grows well in any running stream, forming large beds of leaves. Oz. 40 cts., $1 / 1 \mathrm{lb} . \$ 1.25,1 \mathrm{~b} . \$ 4$.

Extra-Curled, or Pepper-Grass. Of pleasant, pungent flavor; the leaves can be cut several times. The Improved Long Orange. plants grow well in almost any soil, and require little care. Oz. 10 cts., 1/4 lb. $20 \mathrm{cts}$., $1 \mathrm{~b} .50 \mathrm{cts}$. 


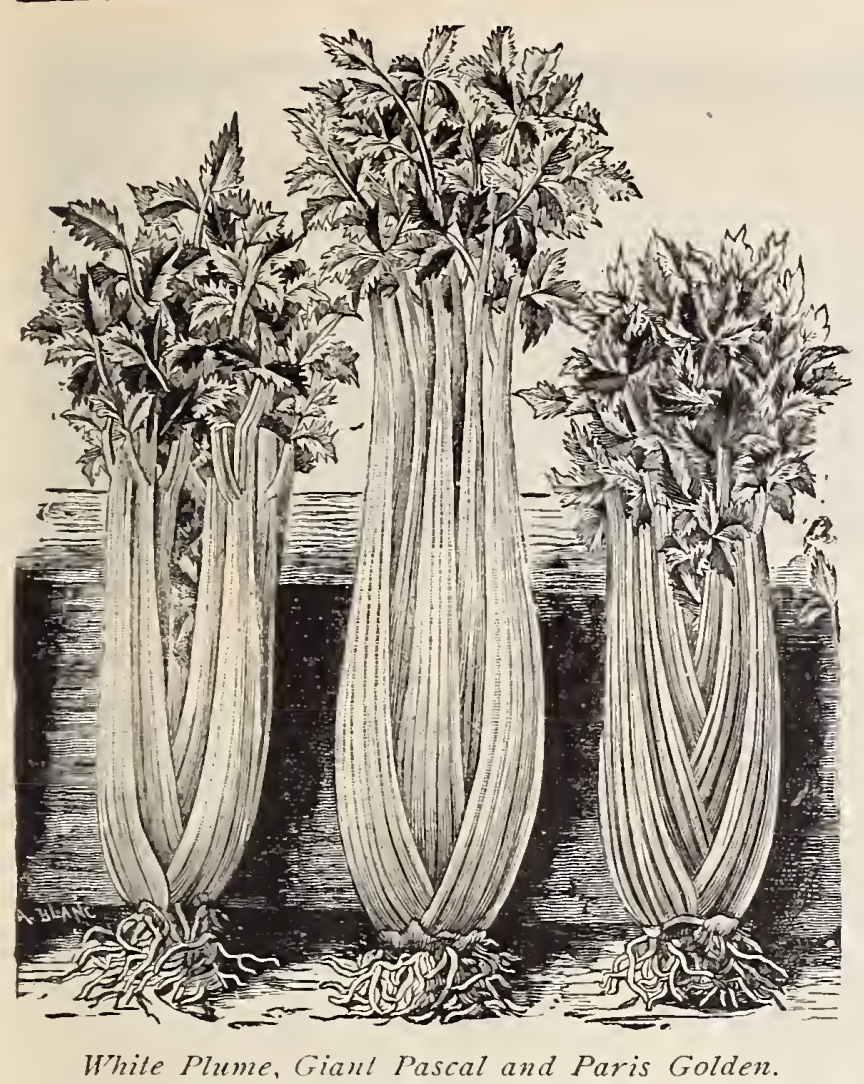

\section{Celery Seed

\author{
(Eellerie)
}

Celery can be grown in any soil, but is finest on deep, mellow bottomland. Seed for early crops should be sown in hotbeds about March I5; if sown too early, the plants are apt to run to seed after being transplanted. The plants may either be thinned to give them room to grow, or transplanted to another bed to grow until it is time to plant them in the open ground. For the main crop, seed should be sown in the open air as soon as the soil and air are warm enough. They should be covered very lightly, or merely pressed into the earth with a board, if the soil is fine and mellow. The seed-bed must be kept free from weeds and well watered in dry weather. When the plants are large enough, transplant them to shallow trenches or furrows from 4 to 6 feet apart, according to the variety grown, setting the plants 6 inches apart in the rows, and pressing the soil firmly around them. They must be well cultivated and kept free from weeds until ready for blanching, which consists in drawing earth up to the stalks at intervals of about two weeks, until all but the tops of the plants are covered. During this process no earth should be allowed to fall into the center of the plant, as this would cause them to rust or decay. Celery may be kept for winter use in pits or cellars, or in deep, narrow trenches, in a dry situation; the latter must be covered with boards, with sufficient soil and manure on top to keep out the frost, leaving openings for ventilation in mild weather at short distance. An ounce of seed will produce about 2,000 plants.

White Plume. A very popular market variety; easily blanched, and one of the handsomest sorts grown. In large plants the stalks, hearts and inner leaves become white without any blanching. Good for fall and summer crops, but does not keep well enough for winter use. Its fine appearance sells it readily in market. For early market use, however, few varieties surpass it. Oz. 25 cts., $1 / 4$ lb. 75 cts., 1b. $\$ 2$.

Pink Plume. Self-blanching; stalks are suffused with pink, and possess the crispness, rich, nutty flavor and long-keeping-characteristics for which red Celeries are noted. Oz. 25 cts., $1 / 41 \mathrm{lb} .75 \mathrm{cts}$., $1 \mathrm{~b}$. $\$ 2.50$

Giant Pascal. The stalks are remarkably broad and thick, and about 2 feet high, yet blanch quickly with but slight banking; their rich, nutty flavor is entirely free from any bitter taste, and they are tender, crisp and stringless; a valuable sort for both early and late use. Oz. 25 cts., 1/41b. 75 cts., lb. $\$ 2.50$.

Paris Golden. Self-blanching; has stalks of beautiful golden yellow, equal in quality to those of any variety grown. Plants semi-dwarf and vigorous, with large, ribbed and rounded stalks, which are quite crisp and tender. Distinguished when quite small by the distinct yellowish green of its leaves. One of the best and handsomest of Celeries. See page 3 . Oz. $40 \mathrm{cts}$., I/4 lb. $\$$ I. 25, 1b. $\$ 5$

Boston Markex. The dwarf, branching variety grown so extensively about Boston. It is unequaled by any other sort, being solid, crisp and of excellent flavor; its compact, dwarf habit allows closer planting, and requires less earthing up than taller sorts. Oz. 30 cts., $1 / 4 \mathrm{lb}$. $\$ \mathrm{I}, 1 \mathrm{~b}$. \$3.

\section{WE USE THE UT. MOST CARE TO HAVE OUR CELERY SEED PURE.}

\section{CELERIAC, or TURNIP=ROOTED CELERY (Anollen Eellerie)}

The seed should be sown in early spring, in light, rich soil, the seedlings transplanted in May, and watered freely in dry weather. They will be ready = for cooking in October, and may be preserved for use during winter in dry sand. Celeriac is said to be as fine a nerve tonic as celery, and can be grown in many sections where celery culture is practically impossible. The roots hare almost the same flavor as the crispest white celery stalks, and do not require half so much care in banking, while they keep perfectly with no more care than a crop of turnips-much longer than celery stalks can be kept in good condition. An ounce of seed will produce about 5,000 plants.

Prague Giant. The roots of this variety are very large and smooth, with no side roots, and sell better in market than those of almost any other sort offered. When young they are quite tender

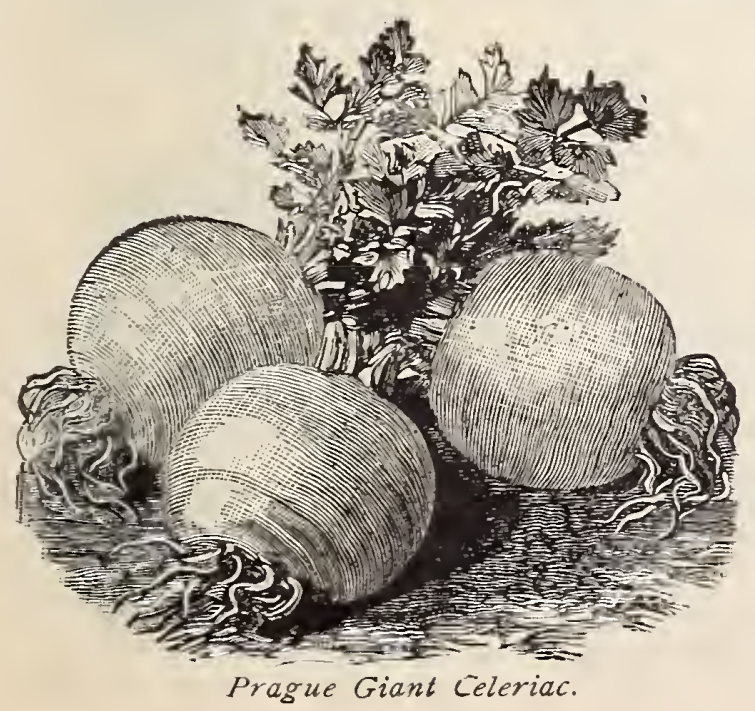
and marrow-like, having a very fine flavor, an
The leaves are used during winter and spring as a salad. Sow the seed thickly in shallow drills in September, and firm the soil well down above it, if the weather is dry. The plants will require no culture beyond keeping them free from weeds should be given a light covering of straw in winter. The richer the soil the finer the flavor of the leaves. In some sections of country this salad is highly appreciated. An ounce of seed will sow a bed 20 feet square.

Large-Seeded. The variety now most generally cultivated. Oz. 10c., 1/2lb. 25c., 1b. $75 \mathrm{c}$. in northern climates they
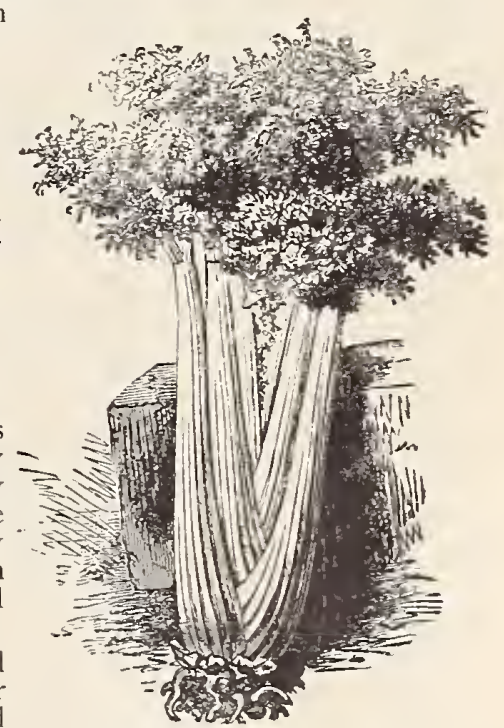

Boston Market Celery.

\section{CORN SALAD, or FETTICUS (sammer salat)}

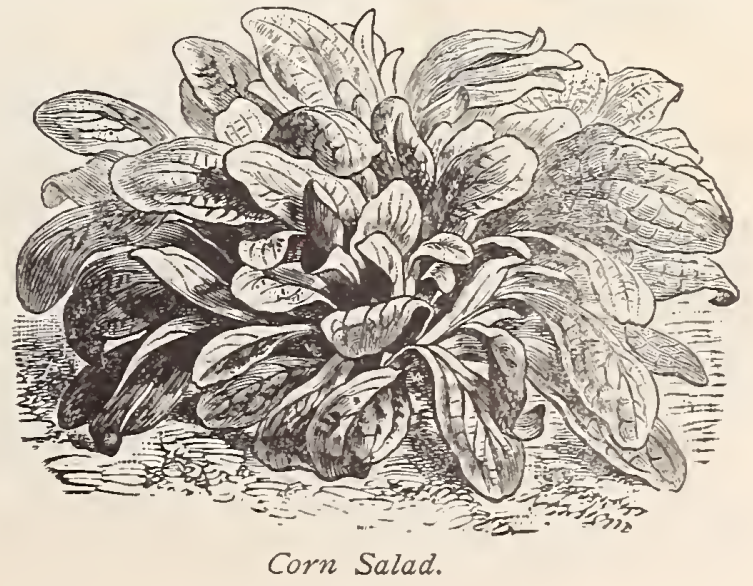




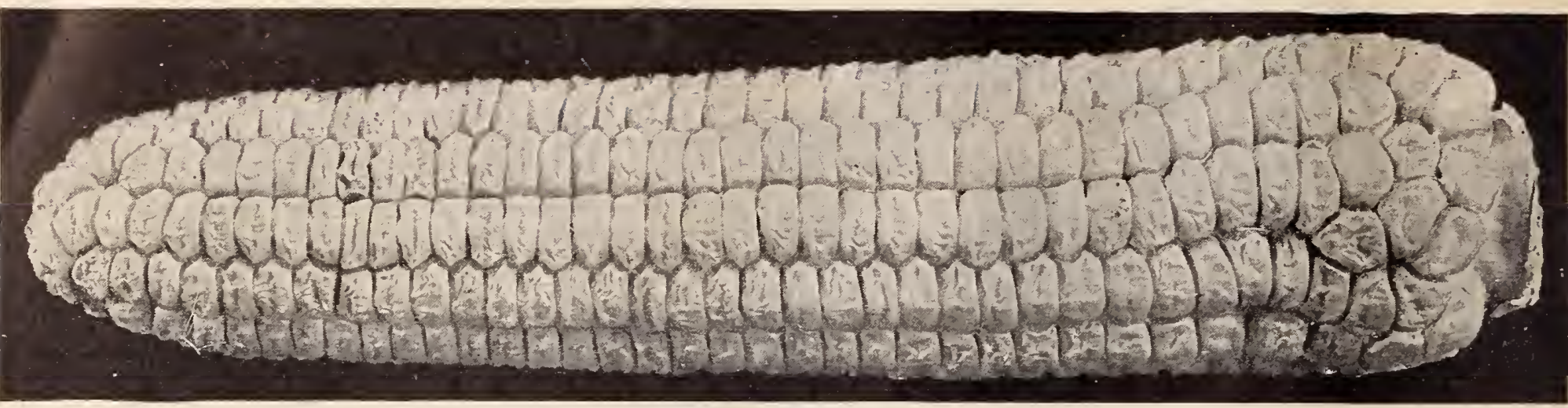

Squantum Sweet Corn

\section{Corn, Sweet or Sugar (פaiz)}

It is our opinion, after several years of testing, side by side, that eastern-grown Sweet Corn is far superior to western in sweetness, and also retains this necessary quality for much longer time. This is also the opinion of many of our local market-gardeners. Our entlre stock for this season we guarantee to be New England-grown. This delicious vegetable may be enjoyed from early summer until $f_{1}$ ost if the proper varieties are selected and planted for succession every two weeks from May until the middle of July. If the seed is planted too early, before the ground becomes warm, it is liable to decay. Plant in hills 3 or 4 feet apart each way, 5 or 6 kernels to a hill; or in rows 4 or 5 feet apart, scattering the seeds thinly in the rows. The taller-growing the variety, the rich $r$ should be the soil and the wider the space allowed for development.

Add 10 cts. per quart on Corn, if to be sent by mail.

\section{A Good Succossion for the Home Garden: CROSBY SQUANTUM EVERCREÉN.}

\section{EARLY VARIETIES}

Caswell's Early MIarlket. A Sweet Corn that will just "fill the bill" with the farmer and market-gardener who wants a large-eared, early Corn. Matures just after the Cory, but with ears averaging Io inches long. Cob and kernels white; good quality and filling out clear to the tip. Qt. 25 cts., $1 / 2 \mathrm{pk}$. 75 cts., bus. $\$ 4$.

Golden Bantam. Stalks about 4 feet high, ears about 6 inches long; grains rich creamy color, and is actually the finest flavored of all Sweet Corn; very early. Qt.25c., $1 / 2 \mathrm{pk}$. $75 \mathrm{c}$., bus. $\$ 4.50$.

Cory: The earliest variety; stalks short; ears set quite low, of fair size, and well filled with large yellowish grains. Qt. $20 \mathrm{cts}$., $1 / 2$ pk. 60 cts, bus. $\$ 350$.

Early White Cory. Identical with Cory, except in color, grains and cob being pure white in this sort, thus removing an cbjection sometimes made to Cory. Q

Motropolitan. A new ear'y sort, only a few days later than the Cory; ears are about 9 inches in length, Io- to $\mathbf{2}$-rowed, large, deep kernels; very sweet It is an excellent variety for market-gardeners. Qt. 20 cts., $1 / 2 \mathrm{pk}$. $60 \mathrm{cts}$., bus. $\$ 3.50$.

Quincy Market. This holds the same rank among early varieties as Potter's Exce'sior does among the later sorts. It comes in just after the Cory and just before the Crosby, but is larger than either. Twelve-ruwed. Qt. $20 \mathrm{cts}$., $1 / 2 \mathrm{pk} 60 \mathrm{cts}$, bus. $\$ 3.50$

\section{SECOND=EARLY AND GENERAL CROP}

Perry's Hybrid. A valuable early market variety. The ears are large and ready fir use quite early; they contain from I 2 to I 6 rows of large, pure white grains. Stalks about 5 feet high, and bear two or more fine ears each. Qt. $20 \mathrm{cts}$., $1 / 2 \mathrm{pk}$. $60 \mathrm{cts}$., bus. $\$ 3.50$.

Eariy Crosby. Ears of medium length, good size, I2-rowed; filled vith thick, sweet grains ; but little later than Perry's Hybrid. Stalks are productive, vigorous and hardy. Qt. $20 \mathrm{c}$., $1 / 2 \mathrm{pk}$. $60 \mathrm{c}$., bus. $\$ 3.50$.
Stabler's Early. One of the earliest of the second-early class, following close after the Cory. The ears are very large for so early a sort, and very sweet. Qt. $20 \mathrm{cts}$., $1 / 2$ pk. $60 \mathrm{cts}$., bus. $\$ 3.50$.

SQUANTUM SWEET. This is the very best Sweet Corn for table use. Our stock is perfectly pure, being grown by us from selected ears. Qt. $20 \mathrm{cts}$., $1 / 2$ pk. $60 \mathrm{cts}$., bus. $\$ 3.50$.

Country Gentleman. Ears of good size, and well filled to the tips with deep, tender, white grains of delicious quality cobs small; stalks productive, averaging three ears each. Superior in quality to any other variety. Qt. $20 \mathrm{cts}$., $1 / 2 \mathrm{pk} .65 \mathrm{cts}$. bus. $\$ 4$.

Stowe11's Evergreen. The standard main-crop variety, grown more generally and on a larger scale than any other sort. Ears large, with deep, tender, sugary grains, and remain fit for use longer after maturity than any other Sweet Corn. This is a very productive and hardy variety, adaptable either as an early or late sort, and fine for private gardens, market and canning. It holds its own very well beside all new sorts. Qt. 20 cts., 1/2 pk. $60 \mathrm{cts}$. bus. $\$ 3$.

Late Mammoth. Enormous size of ears, which frequently weigh from tivo to three pounds; the cobs are large, the grains flat, the quality very good. This is a very productive variety, and matures its ears a little later than Stowell's Evergreen. One of the best of the large-eared sorts. Qt. 20 cts , $1 / 2 \mathrm{pk}$. 60 cts., bus. $\$ 3$.

Bearsfoot. A late variety of extraordinary sweetness large ears; very desirable for market. Qt. 25 cts., t/2pk. 75 cts., bus. $\$ 4.25$.

Our Sweet Corn is all New England-grown.

\section{THE BEST EGGPLANT}

(Eierpflanze)

Sow the seed in hothed early in March, transplant to small pots, and plunge them in the same beds; this is to make them strong and stocky. They should not be planted out in rows until May or June, when the weather becomes warm and settled, as cool nights and wet weather will check their growth. Set the plants in rows 3 feet apart each way, and give them thorough cultivation, drawing the earth up to the stems when they are about a foot high; it is well to keep some plants in the hotbed for replanting. Repeated sowings are sometimes necessary, as the seed does not germinate freely without strong and uniform heat In cutting the fruit, be careful not to injure the plants. An ounce of seed will produce I, Ooo plants.

Black Beauty. New. (See page 3.) Oz. 40 cts., $7 / 41 \mathrm{~b} . \$ 1.25,1 \mathrm{~b} . \$ 4.50$.

New York Improved Thornless. The leading market variety, strong and productive in habit. The fruits are deep purple, large and smooth, entirely free from thorns, and the flesh is white, tender and delicate-flavored. The plant is robust and a good yielder on all rich soils. Oz. 40 cts., $1 / 4$ lb. $\$ 1.25,1$ b. $\$ 4.50$

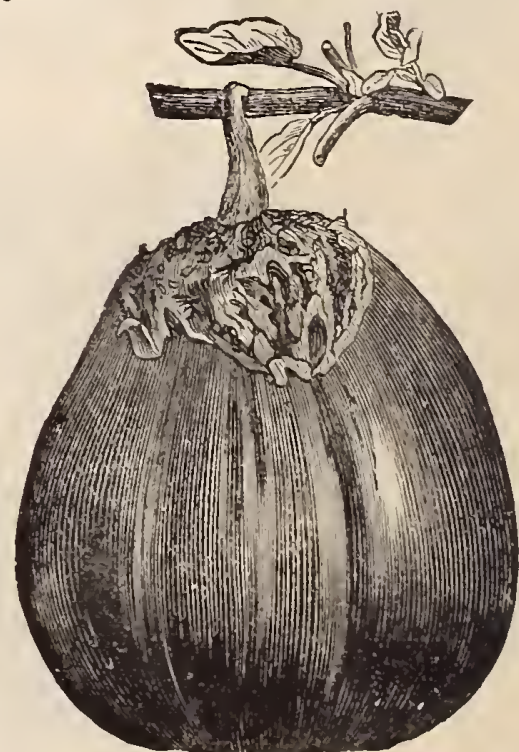

New York Improved Eggplant. 


\section{Cucumber}

(BSurfe)

\section{ALL THE BEST SORTS FOR SALADS AND PICKLING}

For general crops the seed cannot be planted in the open ground before the weather has become warm and settled and the ground mellow and light. Plant the seeds in well-enriched hills about 4 feet apart each way, and as soon as all danger from insects is over, thin the plants to leave 4 of the strongest in each hill. For succession, sow at intervals of every two weeks until midsummer. Extra early crops may be grown by planting the seeds in hotbeds in April, upon pieces of sod turned upside down, and removing these to hills in the open ground as soon as the weather is warm enough. For pickles, sow the seed from the middle of June until the middle of July The vines bear longer if the fruits are gathered as soon as they are large enough; their strength is soon exhausted by ripening fruit. An ounce of seed will plant 50 hills ; 2 pounds will plant an acre.

Rawson's White Spine. Grown by IV. W. Rawson, and sold by us under his seal. Oz. 30 cts., $1 / 1$ b. $\$ \mathrm{I}, 1 \mathrm{~b}$. $\$ 4$.

Boston Picking. Very popular for pickles ; fruit smooth and symmetrical, but slightly pointed at the ends; bright green. Oz. IOc., $1 / 4 \mathrm{~b} .25 \mathrm{c}$., $1 \mathrm{~b}$. $80 \mathrm{c}$.

Improved White Spine. Early and productive, and suitable either for forcing or outdoor crops. Fruit of medium size, good shape, light green, with a few white spines on the surface. Oz. 10c.

I/ lib. 25 cts., lb. $80 \mathrm{cts}$.

Cumberland. The best pickling sort yet introduced, being very handsome and productive, with flesh firm but very crisp and tender at all stages of growth; straight and symmetrical. Oz. 10 cts., $\pi / 41 \mathrm{lb} .25 \mathrm{cts} ., 1 \mathrm{~b} .80 \mathrm{cts}$.

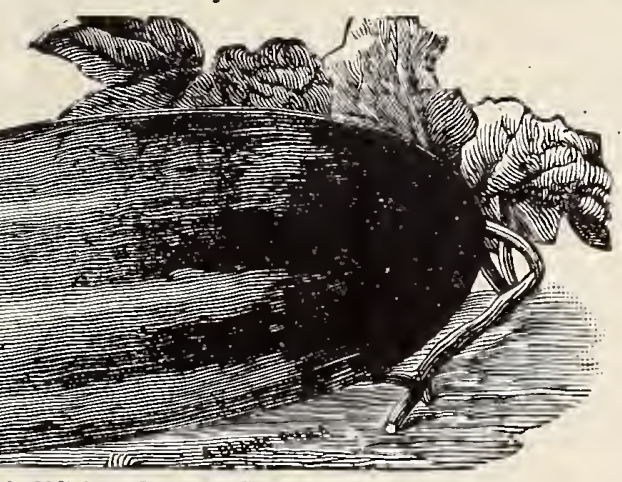

improved White Spine Cucumber

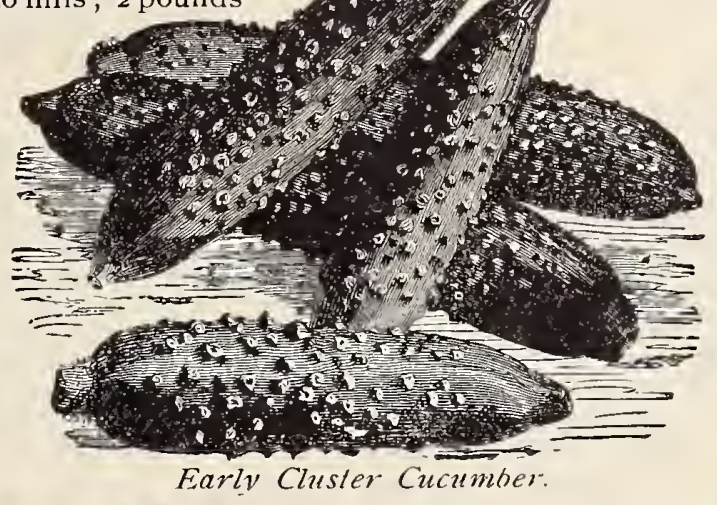
salads or pickles. Oz. Io cts., I/41b. $25 \mathrm{cts}$., $1 \mathrm{~b} .80 \mathrm{cts}$ pointed, crisp and good. Oz. Io cts., I/4lb. $25 \mathrm{cts}$., 1b. $80 \mathrm{cts}$.

Japanese Climbing. Vigorous, tall-climbing, and clings tightly to trellises. Fruits almost straight, large, and from I2 to I 6 inches long; skin dark green; flesh thick and delicately flavored. Oz. Io cts., $1 / 41 \mathrm{~b} .30 \mathrm{cts}, 1 \mathrm{~b} . \$ \mathrm{I}$.

West India Gherkin. Its small, rough, prickly fruits are used for pickling. The vines grow quite rapidly and bear heavily. $\mathrm{Oz}$. 20 cts.

English Frame, Best Varieties. Sion House, Teiegraph. $25 \mathrm{cts}$. each per packet.

\section{ENDIVE (The Winter Salad) (Endivie)}

This is an important fall and winter salad. For early the seed should be sown in April, in drills 15 inches apart, and the seedlings thinned to stand 12 inches apart in the rows. Sowing for the main crop can be made in June and July, as the vegetable is used principally in fall and winter. The inner leaves may be blanched to a beautiful yellowish white in from 3 to 5 weeks, by tying the tips of the outer ones together, or by laying boards over the plants. Ordinarily good soil and culture are all the crop requires. An ounce of seed will sow roo feet of drill.

Green Curled. The one most generally cultivated. Dark green leaves, beautifully curled, and when blanched very crisp and tender; they are ready for use a little earlier than the other sorts. Oz. $20 \mathrm{cts}$., $1 / 4 \mathrm{lb} .50 \mathrm{cts}$., $1 \mathrm{~b} . \$ \mathrm{I} .50$.

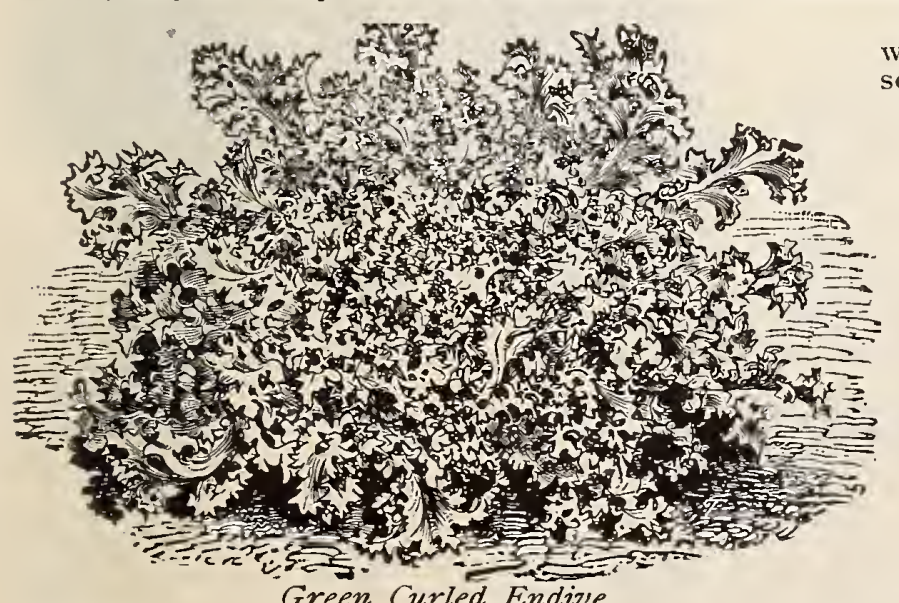

Broad-Leaved Batavian. The broad, thick leaves make excelient salads when blanched. The plant is very hardy, and yields heavier crops than other sorts, but does not blanch so easily. Oz. 20 cts., $1 / 41 \mathrm{lb} .50 \mathrm{cts}$., $1 \mathrm{~b} . \$ \mathrm{~T} .50$.

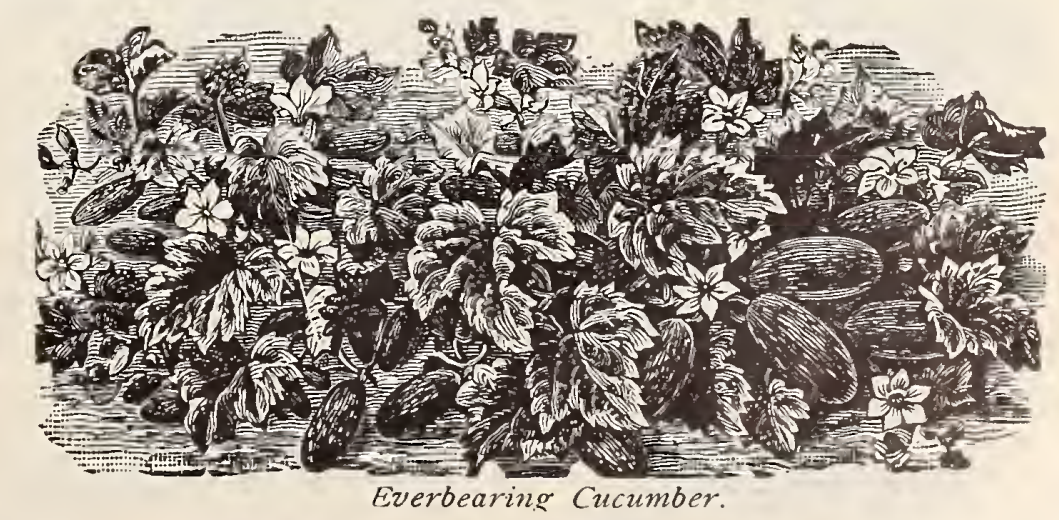

ALL VEGETABLE SEEDS SOLD AT THE UNIFORM PRICE OF 5 CENTS PER PACKET 


\title{
KALE, or BORECOLE
}

\author{
( $\mathfrak{n}$ raustohl)
}

Under this name are classed several species of the cabbage family which do not form heads. Some of them have very tender leaves of delicate flavor, and all are quite hardy, and improved rather than injured by frost. Sow the seed in beds in April or May, and transplant and cultivate the seedlings like cabbage. They will grow in almost any soil, but both the flavor of the leaves and the yield is greatly improved by a rich one. An ounce of seed will sow about 200 feet of drill.

Dwarf German Greens (Siberian Kale). A standby everywhere for winter greens. The seed is generally sown broadcast, but can be sown in drills a foot apart in September, and the plants treated like spinach; they will be ready for use early.in the spring. Oz. I5 cts., $1 / 4 \mathrm{lb} .35 \mathrm{cts}$., $1 \mathrm{~b} . \$ \mathrm{I}$.

Dwarf Curled Green Scotch. A dwarf-spreading variety, seldom exceeding I8 inches in height, but rounding out to a diameter of 3 feet under good cultivation. The leaves are bright green, tender and elegantly curled. The variety is very hardy and one of the best grown. Two weeks later than the preceding sort, but stands longer before going to seed. Oz. I5 cts., I/4 1b. $35 \mathrm{cts} ., 1 \mathrm{~b}$. \$1.
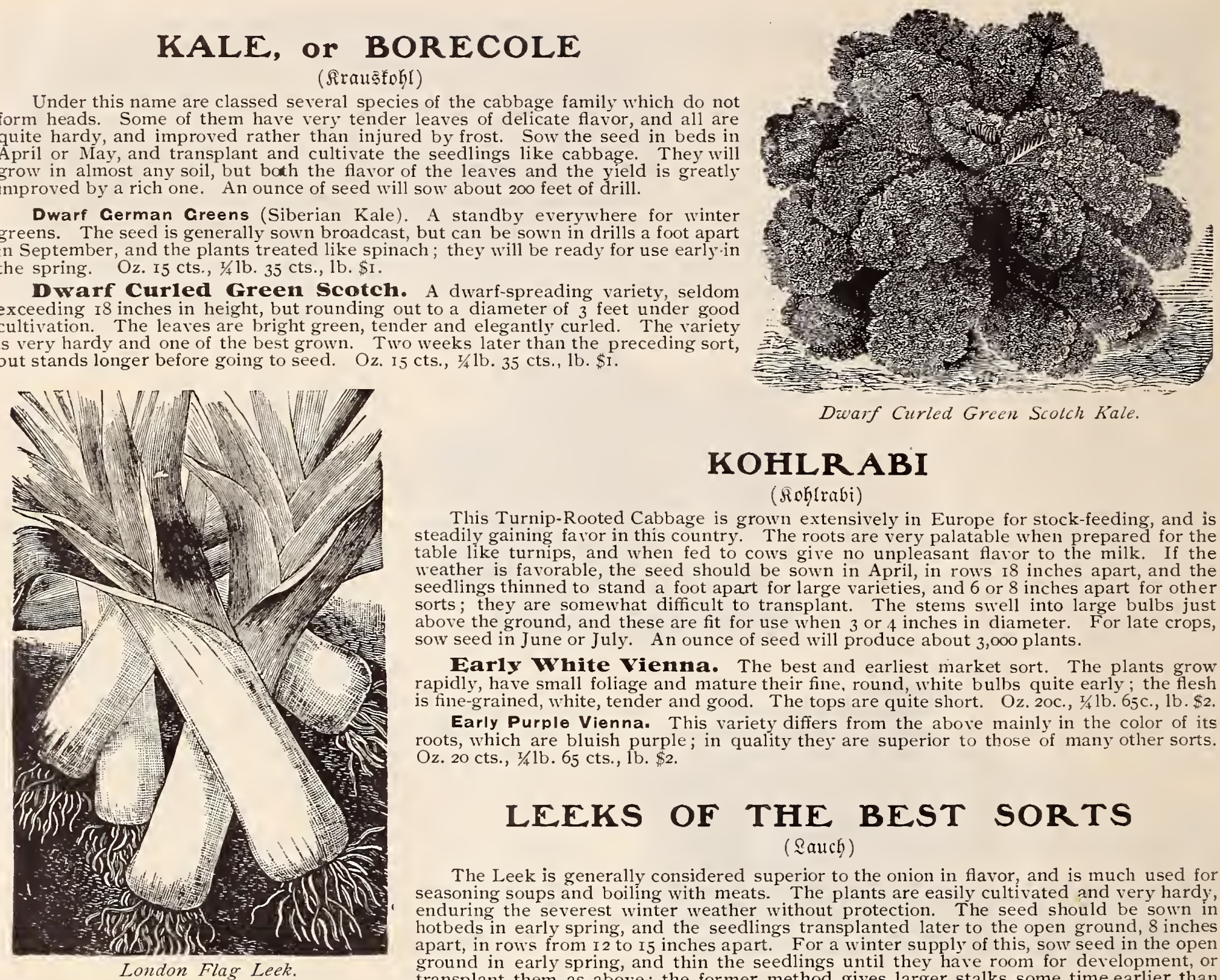

\section{KOHLRABI}

(Rofirabi)

This Turnip-Rooted Cabbage is grown extensively in Europe for stock-feeding, and is steadily gaining favor in this country. The roots are very palatable when prepared for the table like turnips, and when fed to cows give no unpleasant flavor to the milk. If the weather is favorable, the seed should be sown in April, in rows I8 inches apart, and the seedlings thinned to stand a foot apart for large varieties, and 6 or 8 inches apart for other sorts; they are somewhat difficult to transplant. The stems swell into large bulbs just above the ground, and these are fit for use when 3 or 4 inches in diameter. For late crops, sow seed in June or July. An ounce of seed will produce about 3,000 plants.

Early White Vienna. The best and earliest market sort. The plants grow rapidly, have small foliage and mature their fine round, white bulbs quite early t the flesh is fine-grained, white, tender and good. The tops are quite short. $\mathrm{Oz} .2 \mathrm{Oc}$., $1 / 4 \mathrm{~b} .65 \mathrm{c} ., 1 \mathrm{~b} . \$ 2$.

Early Purple Vienna. This variety differs from the above mainly in the color of its roots, which are bluish purple; in quality they are superior to those of many other sorts. $\mathrm{Oz}, 2 \mathrm{O}$ cts., $1 / 4 \mathrm{lb} .65 \mathrm{cts}$, , lb. $\$ 2$.

\section{LEEKS OF THE BEST SORTS ( $(\mathfrak{a u c h})$}

The Leek is generally considered superior to the onion in flavor, and is much used for seasoning soups and boiling with meats. The plants are easily cultivated and very hardy; enduring the severest winter weather without protection. The seed should be sown in hotbeds in early spring, and the seedlings transplanted later to the open ground, 8 inches apart, in rows from 12 to 15 inches apart. For a winter supply of this, sow seed in the open ground in early spring, and thin the seedlings until they have room for development, or transplant them as above; the former method gives larger stalks some time earlier than when the roots are transplanted. They should be stored like celery for winter. An ounce of seed will sow about ioo feet of drill.

Musselburg. A hardy, popular sort, with broad, spreading leaves and very large stalks.. Pkt. 5 cts., oz. 30 cts., $1 / 4 \mathrm{lb}$. $\$ \mathrm{I}, 1 \mathrm{~b} . \$ 3.5 \mathrm{O}$

London Flag. The variety most extensively cultivated. The stalks are large, and the leaves grow from their sides, as in the Flag. Oz. 20c., 1/41b. 6oc., 1b. $\$$ I.75.

\section{DANDELION (2ömenzahn)}

Furnishes our earliest and most healthful crop of spring greens. Sow the seed as

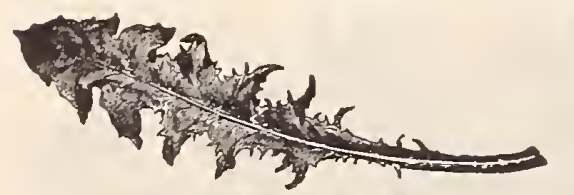
early as the weather will allow, in good, cover them only one-fourth of an inch deep, and firm the soil down above thein. The plants should be thinned to stand 2 or 3 inches apart in the rows, that the roots inay grow large and solid, thus saving much time

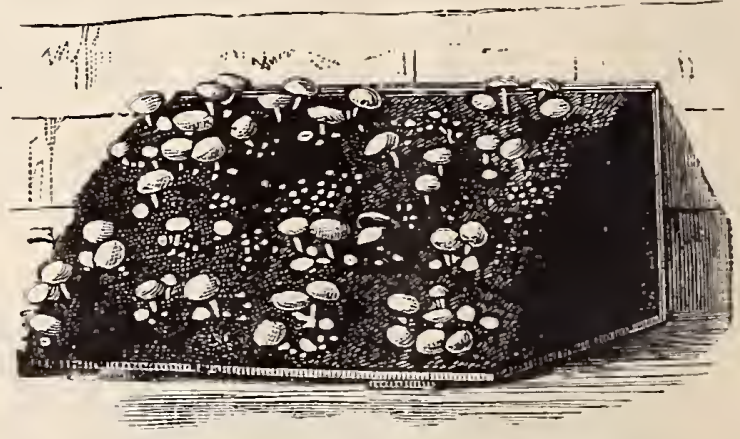

Mushroom Spawn.

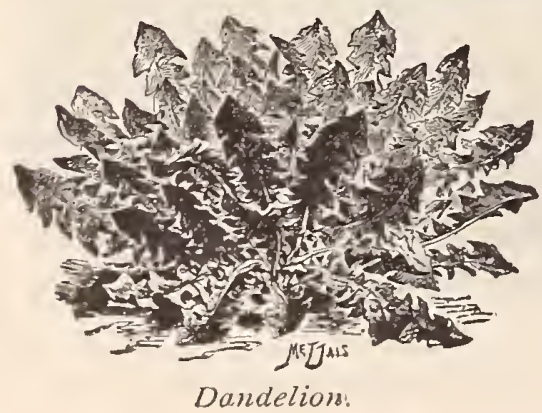

in trimming them. An ounce of seed will sow roo feet of drill; a pound will sow an acre.

Improved American, Thick-Leaved. The best variety. Oz. fo cts., $1 / 4 \mathrm{lb}$. $\$$ I. $25,1 \mathrm{~b} . \$ 4$.

\section{MUSHROOM SPAWN}

\section{( 5 Gampignonbrut)}

Provide a sufficient quantity of fresh stable manure, and throw into a heap to heat. Turn and mix several times, till the heat is evenly distributed, and then make the bed under cover, similar to a hotbed. When the heat is found to be gentle, prepare the spawn by breaking into pieces about 2 inches square, and place them 6 inches apart each way; spread over them I inch of good loam. Cover with straw, and if the loam becomes dry, water with tepid water.

Fine English, “Milltrack.” Lb. I5 cts., 8 lbs. \$I.

Best Quallty, Home-Made. Lb. I.5 cts.. 8 lbs. \$r. (Special price in quantity.) 


\section{Lettuce}

(Garten Salat)

Lettuce is a plant of most simple culture when grown in the open air. It requires ricl soil, plenty of well-rotted manure and abundant moisture. IVith these conditions, its growth is vigorous and rapid; and to be crisp and tender it should be grown quickly. Of all the sakad plants, Lettuce easily takes the lead; and no garden is worthy the name without its Lettuce beds. 1t has few, if any, insect enemies, and flourishes throughout the spring and summer months. Drought and hot weather are its worst enemies, as during such periods it inclines to run up to seed. Seed may be sown in a frame in February or Narch, not much bottom heat being required. The plants may be set out as early as the ground can be worked, as light frosts will not injure them. Set in rows about I8 inches apart, leaving 8 or Io inches space between the plants. For successive crops, sow every two weeks up to July. One ounce will produce 3,ooo plants.

Boston Market (White-seeded Tennisball). Grown extensively by marketgardeners, under glass, for winter use; very compact head and of the best quality. Oz. I5 cts., I/4lb. 50 cts., lb. $\$ I .50$.

Tomhannock. Leaves almost white, crisp and tender; edges of the outer leaves reddish bronze; very handsome. Oz. I5 cts., $1 / 4 \mathrm{lb} .50 \mathrm{cts}, 1 \mathrm{~b} . \$ 1.50$.

Salamander. A valuable outdoor Lettuce. Of large size, solid, good color: stands well during the hot summer months. Oz. I5 cts., 1/4lb. $50 \mathrm{cts}$., 1b. \$1.50.

Denver Market. Leaves wrinkled like savoy cabbage. Large heads, light green color; flavor fine and delicate; quite early. A well-known and very popular Lettuce. Oz. I5 cts., 1/4lb. 50 cts., lb. \$I.5O.

Black-seeded Simpson. A popular variety, excellent both for forcing and open ground crop. Grows very rapidly, withstanding heat and drought unusually well, and forming large, bushy, light-colored stalks. Oz. I5 cts., 1/4 lb. $50 \mathrm{cts}, 1 \mathrm{~b}$. $\$ 1.50$.

White-seeded Simpson. For sowing broadcast early in spring for yathering Lettuce. Leaves delicate light green, very curly and well flavored. Oz. I 5 cts., I/ lb. 50 cts., lb. \$I 50 .

Black-seeded Tennisball. This variety is the most popular for open-air culture it forms a handsome, compact head, with very few outside leaves, and is crisp and tender. Oz. I 5 cts., I/4lb. 50 cts., lb. \$1.50.

Big Boston. Similar to Boston Market, with heads twice as large, and a week later in maturing for use. The solidity and large size of the heads make them of great value for general crop. Oz. I5 cts., I/ 1 lb. 5o cts., 1b. $\$ 1.50$.

A11-the-Year Round. Nay be grown at any season of the year. Heads of medium size, firm, close, crisp and very good. Oz. I5 cts., 1/4lb. 50 cts., lb. \$r.5o.

Manson. Large and rigorous, and forms immense heads; leaves green, light yellow within; sweet, crisp. One of the best. Oz. I5 cts, $1 / 1 \mathrm{lb} .50 \mathrm{cts}$., $1 \mathrm{~b}$. \$1.50.

Curled Silesia. Very early and tender; a favorite in the family garden. Oz. I5 cts, $1 / 4$ lb. 50 cts., 1b. \$I.5o.

White Paris Cos. A sort with long, narrow, upright leaves; does not head, but when tied up blanches very nicely; bears close planting. $\mathrm{O} z$. I $5 \mathrm{cts}, \mathrm{I} / \mathrm{lb} .50 \mathrm{cts}$. 1b. $\$$ I.5O.

\section{MARTYNIA}

(Giemientorn)

The seed-pods are excellent for pickling if gathered when tender and about half grown. Sow the seed in May in rows 3 feet apart, and thin the plants to stand 2 feet apart in the rows.

Proboscidea. The best variety. Oz. 30 cts., $1 / 4 \mathrm{lb} . \$ \mathrm{I}, \mathrm{lb} . \$ 3$.

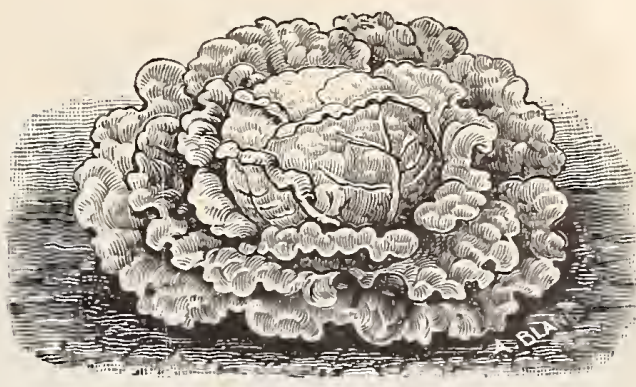

Boston Warket Lettuce.
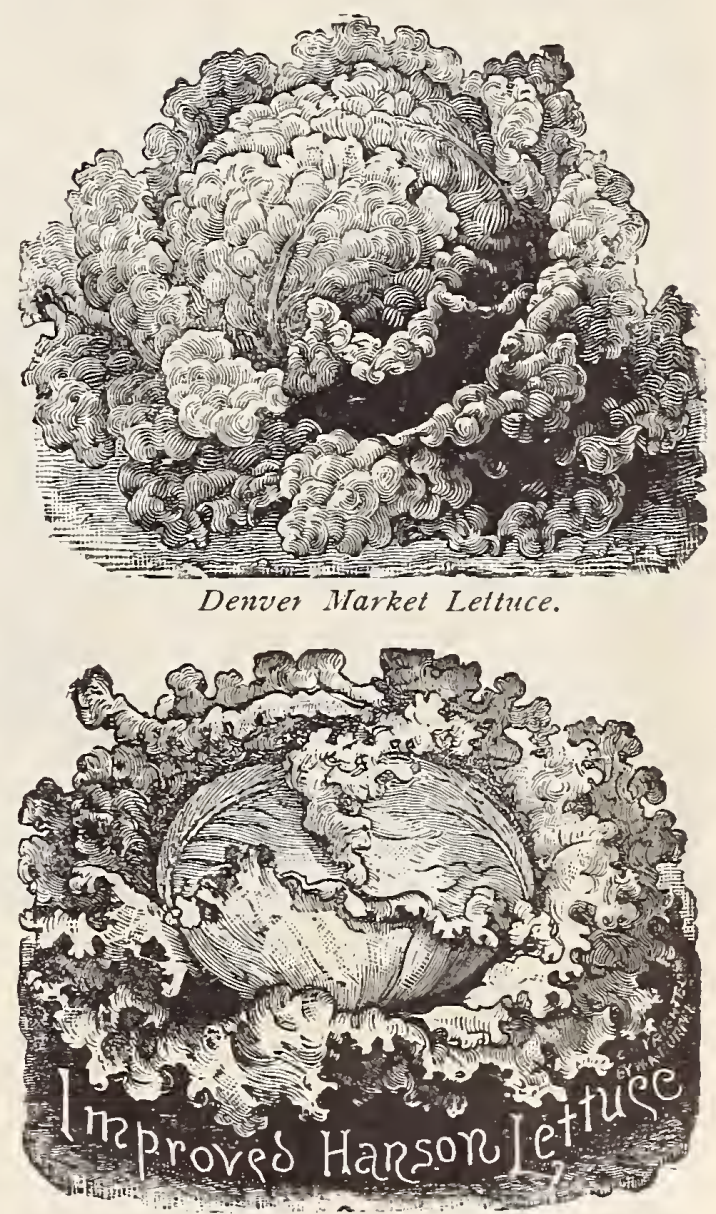

\section{MUSTARD}

\section{(ङení)}

The young and tender leares of the Mustard are greatly relished a salads, or when cooked like spinach. The seed should be sown in shallow

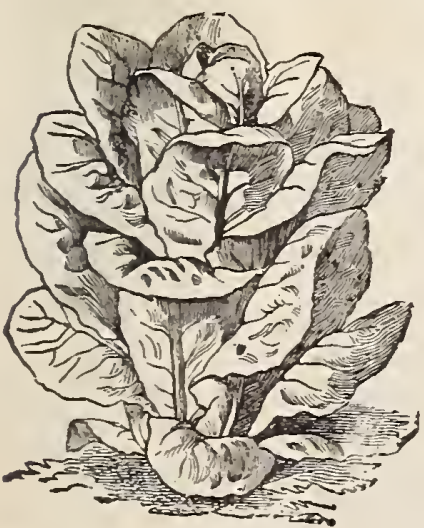

White Paris Cos Lettuce. drills as early as the oround call ke pre. pared in spring, and the leaves cut when several inches long. Oz. Io cts., $1 / 4 \mathrm{lb}$. I $5 \mathrm{cts}$. lb. $30 \mathrm{cts}$

\section{NASTURTIUM}

\section{indianiähre}

The seeds while young and tender are pickled and used as capers. The plants are highly ornamental; the tall varieties make an excellent screen for unsightly places in the garden or along fences anywhere.

Tall Mixed Colors. Oz. Io cts., $1 / 4 \mathrm{lb}$. $30 \mathrm{cts}, \mathrm{lb}$. \$I.

Dwarf Mixed Colors. Oz. Iocts, , $1 / 4 \mathrm{lb}$ 30 cts., lb. \$I.

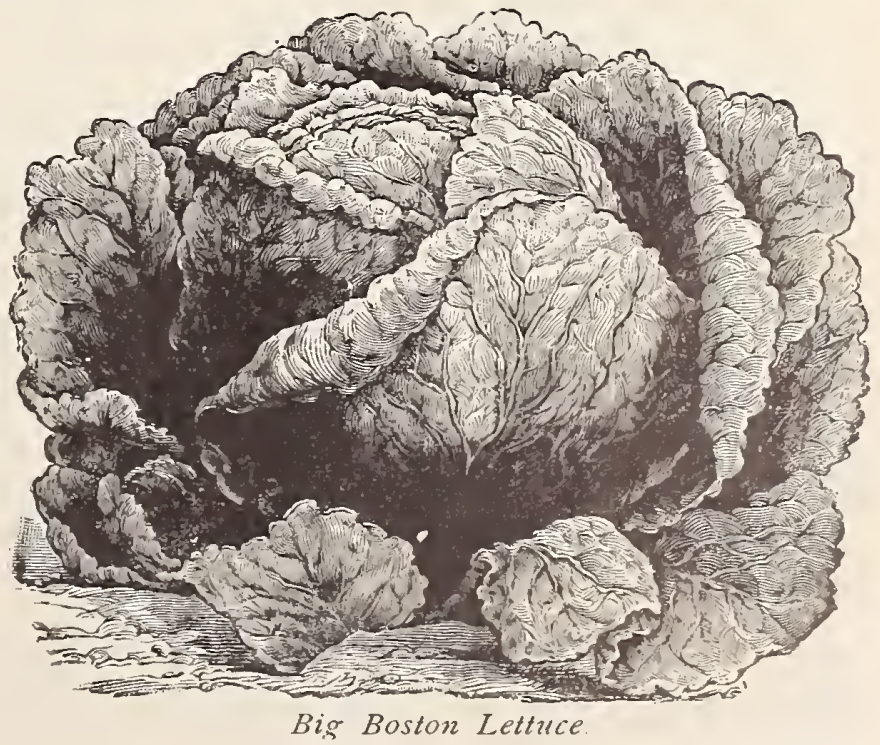

Our Lettuce is all New England=grown from Selected Stocks. 


\section{Muskmelons}

Muskmelon seed should not be planted outdoors until all danger of frost is over and the ground has become warm and dry. The hills should be about 6 feet apart, and carefully prepared. Rich earth is far better for the young plants than manure, but if the latter must be used, see that it is well rotted. Plant from six to twelve seeds in a hill, and when the young seedlings are strong enough to

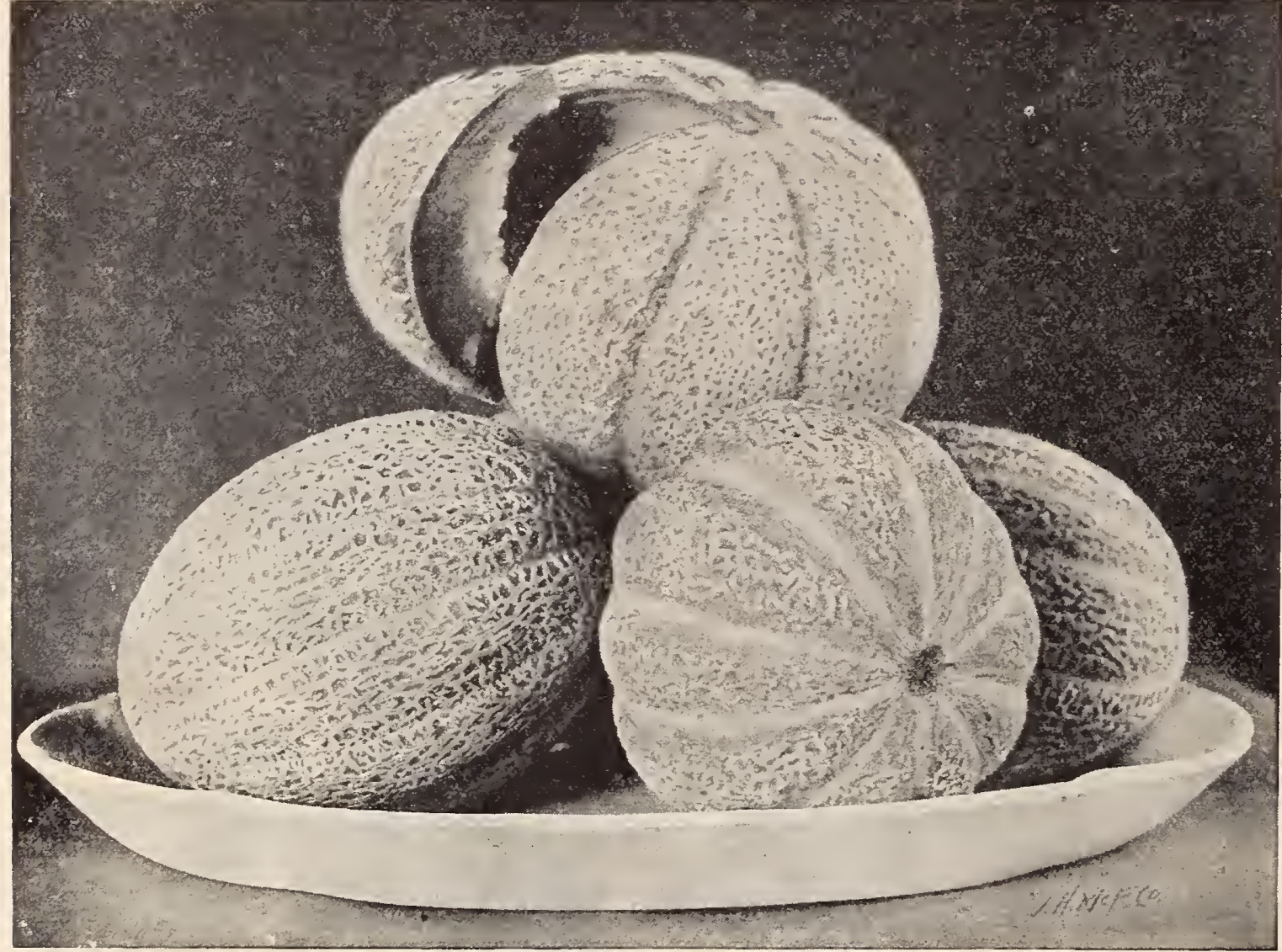

Extra-Early Hackensack and Rocky Ford resist the attacks of insects, thin them, leaving three of the strongest in each hill. The vines should have clean cultivation until they cover the ground, and if they grow too rank the tips of the shoots should be pinched off, causing them to set more fruits and develop them to finer size. An ounce of seed will plant about 80 hills.

Extra-Early Mack. ensack. A selection from the Hackensack, and with fruits much like the parent, but ready for market ten days earlier. Of good size, weighing from 5 to Io pounds each. $\mathrm{Oz}$. $10 \mathrm{cts}$., $1 / 41 \mathrm{lb} .25 \mathrm{cts}$, lb. $80 \mathrm{cts}$.

Emerald Gem. Early, with small, smooth - ribbed, dark green fruits; flesh thick and salmon-colored, granular, sweet and rich; very delicious and satisfying to the taste; the vines bear heavily. Oz. I5c., x/4lb. 40 cts., lb. \$1.25.

Princess, or Perfecfion. Notably fine, with fruits having flesh so thick and seed cavity so small that they seem almost solid. Rind thin, tough and sparingly netted: flesh rich salmon, fine-grained sugary and melting; vines strong and productive; one of the best, and also one of the most popular Muskmelons known to market-gardeners. Oz. 10 cts., $1 / 4 \mathrm{lb}$. $25 \mathrm{cts}, 1 \mathrm{~b} .8 \mathrm{oc}$.

Miller's Cream, or Osage. Fine, attractive fruits, which sell quickly in market, and, therefore, a favorite among the truckers. The fruits are large and round, with light green, netted skin and thick, sweet, salmon-colored flesh. Oz. $10 \mathrm{cts}$., 1/4 Ib. $25 \mathrm{cts}$., Ib. $80 \mathrm{cts}$.

White Japan. One of the smallest varieties, of a pale, greenish white color. It is both early and prolific, and its flavor and sweetness are unsurpassed. Oz. Io cts., I/4lb. $25 \mathrm{cts}$., lb. $80 \mathrm{cts}$

Arlington Nutmeg. A popular variety, extensively grown by market vegetable growers; good flavor; flesh yellowish green. Oz. Io cts., I/4lb. 25 cts., lb. 80 cts.

Livingston's Tiptop. A new and very distinct variety, first discovered in a large field in Lancaster county, Pennsylvania. In quality it is one of the best of the yellow-fleshed sorts. Of good size, and its appearance is very captivating. Oz. 10 cts., $\mathrm{T} / 4 \mathrm{lb}$. 25c., lb. $80 \mathrm{c}$.

Long Island Beauty. Round; one of the earliest and finest. Oz. $10 \mathrm{cts}$., $\mathrm{T} / 4 \mathrm{lb} .25 \mathrm{cts} ., 1 \mathrm{~b} .80 \mathrm{cts}$.

Surprise. One of the finest. The melons ripen early and have a thin, cream-colored rind, and thick, sweet, salmon-colored flesh. Oz. Io cts., $1 / 1 / 1$ lb. 25 cts., 1 b. 80 cts.

Paul Rose. Medium size, rather elliptical in shape, netted, salmon-fleshed, and so thick-meated as to be almost solid; quality firstclass. It is a cross between the netted Gem and the Osage, or Miller's Cream. Oz. 1o cts., 1/4 Ib. 25 cts., $1 \mathrm{~b}$. $80 \mathrm{cts}$.

Rocky Ford. This new and valuable introduction has attained a great reputation in a very short time. It is oval in shape, of a delicate flavor; flesh light green; size medium. A good shipper. Our engraving from a photograph perfectly.represents it. This is the melon which has made so much inoney for Colorado shippers. Oz. Io cts., 1/41b. 25 cts., 1b. 80 cts.

\section{Watermelons (æaafiermelonen)}

An effort should be made to secure good, strong vines early in the season, and this can be done by taking care that the hills are large, mellow and well drained, with the manure placed so that they will not dry ont quickly under hot suns. All possible protection from insects should be given the young plants, and their growth may be hastened still further by frequent applications of liquid manure. As a protection from insects, netting is frequently used, and also dry ashes or coal-dust sprinkled over the leaves when wet. Plant the seeds thickly, and thin the plants to four of the strongest in each hill. An ounce of seed will plant about 60 hills.

Cole's Early. A fine early Watermelon ; can be grown over fleshed, with light-colored seeds; quite hardy and very productive; a large latitude; flesh bright red, delicate in texture; fruit nearly round; rind thin. Oz. Io cts., $1 / 4 \mathrm{lb} .20 \mathrm{cts}, 1 \mathrm{~b}$. $60 \mathrm{cts}$.

Sweetheart. Large and nearly globular; skin bright, mottled green; flesh bright red, firm and heavy, crisp, melting and exceedingly sweet. A good shipper and keeper. Oz. Ioc., I/41b. 20c., 1b.6oc.

Kolb Gem. Unusually prolific; fruits very large, roundish oval, with rind as hard and tough as in a winter squash, and striped with light and dark green. Oz. 1o cts., $1 / 4 \mathrm{lb} .20 \mathrm{cts}$, 1b. $60 \mathrm{cts}$.

Phinney's Early. A very early variety, of medium size; redfleshed, with light-colored seeds; quite hardy and ve
quality excellent. Oz. $10 \mathrm{cts}$., $1 / 4 \mathrm{lb}$. $20 \mathrm{cts}, 1 \mathrm{~b} .60 \mathrm{cts}$.

Cuban Queen. One of the very best new varieties, of round shape and of large size; flesh bright red, very crisp, delicate and swert; an early and reliable sort. Oz. 1octs., $1 / 41 \mathrm{lb}$. 20 cts., lb.6octs. Mountain sweet. An old favorite; form rather long; color dark green; seeds dark; a very solid melon, sweet and crisp; a safe variety for northern growing. Oz. $10 \mathrm{cts}$, $\mathrm{x} / 4 \mathrm{lb} .20 \mathrm{cts}$., $1 \mathrm{~b}$. $60 \mathrm{cts}$.

Red-seeded Citron. Round, marbled with light green. Flesh white and solid, seeds red. Oz. Io cts., $1 / 4 \mathrm{lb} .20 \mathrm{cts}, 1 \mathrm{~b} .60 \mathrm{cts}$. 


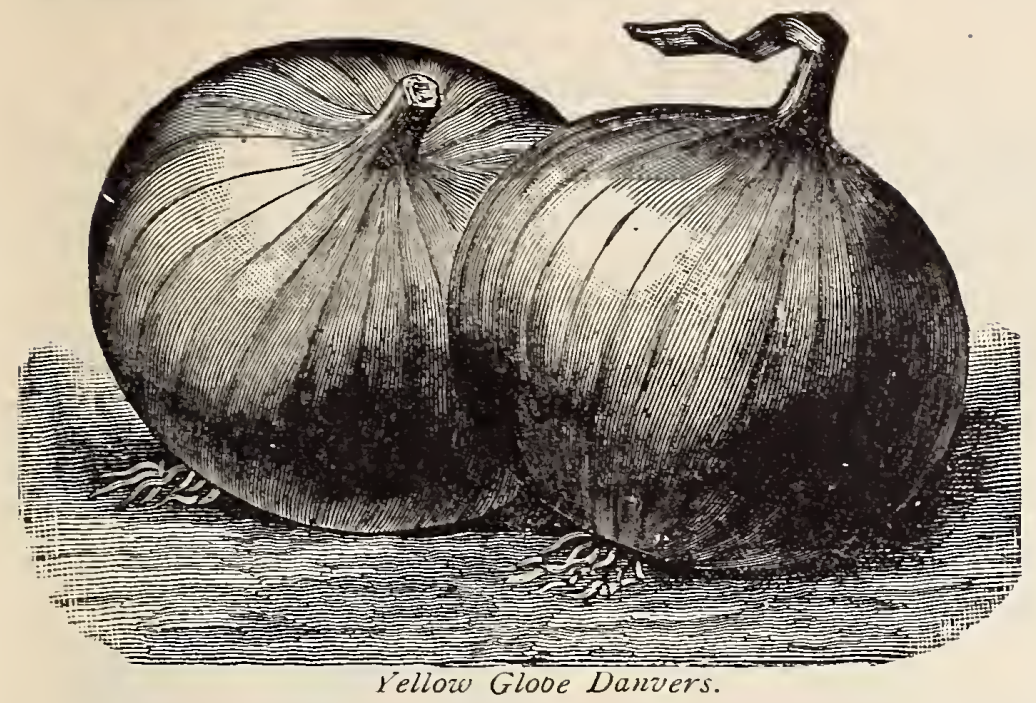

\section{Onion Seed}

(Bivieber)

All New England-grown

The Onion has been cultivated as an article of food from the earliest times, and is now perhaps more universally grown than any other vegetable. A good crop is impossible unless the soil is very rich and kept clean. Use well-rotted manure freely, and get the crop in as soon as possible in the spring, no matter if the weather is cold and unpleasant. Sow in drills I foot apart, and cover about one-third of an inch, treading or rolling after sowing, so that the hot dry atmosphere may not dry up and destroy the sprouting seed. When 3 inches high, thin to 2 inches apart. Stir the ground freely without

GOOD ONION SEED is the foundation for a

Good Crop of Onions

free from weeds. One ounce to Ioo feet of drill ; 4 to 5 pounds per acre.

Yellow Globe Danvers. Buxton type, selected, home-grown stock. Globe-shaped; early, with very small neck large size ; fine quality and good keeper; the best for general crop. Oz. $20 \mathrm{cts}$, , $/ 41 \mathrm{lb} .75 \mathrm{cts}, 1 \mathrm{lb} . \$ 2.50$.

Red Wethersfield. One of the most productive and long-keeping. Bulbs deep purplish red, large, flat, strong-flavored and grow to a large size the first year from seed. Oz. 20 cts., $1 / 41 \mathrm{lb}$. $60 \mathrm{cts}$., lb. $\$ 2$.

Extra-Early Red Globe. Of the famous Southport type, as handsome and much earlier, maturing with Early Flat Red and Danvers. Oz. $20 \mathrm{cts}, 1 / \mathrm{lb}$. $75 \mathrm{cts}, 1 \mathrm{~b} . \$ 2.50$.

Southport White Globe. A large, showy, globular white Onion, which sells quickly in market. The bulbs grow quite rapidly, and if the seed is sown early, good-sized roots, suitable for pulling and marketing in a green state, are soon formed. They are mild flavored, keep well and the yield is good. Oz. 20 cts., $1 / 41$ b. 75 cts., 1 b. $\$ 2.50$.

White Portugal, or Silverskın. Largely grown for white Onion sets. Bulbs large and fine in appearance, with silvery white skin, and sweet, tender white flesh; they do not keep well, but are nild flavored, and excellent for family use and for pickling. Oz. $20 \mathrm{cts}$, , $1 / 4$ lb. 75 cts., 1 b. $\$ 2.50$.

Spanish King, or Prizetaker. Bulbs very large, round and handsome; rich yellow skin and nild, sweet, pure white flesh; quite free from stiff necks; bottom well and yield enormously. A very desirable sort. Oz, 20 cts., $1 / 4 \mathrm{lb}$. $60 \mathrm{cts}$., $1 \mathrm{~b}$. $\$ 2$.

\section{ONION SETS}

These are small Onions grown the previous year, ripened off and taken up when mere bulblets. They produce a very early and profitable crop, and grow in any good soil. Set them in rows I foot apart and 3 inches apart in the rows.

White Sets, Yellow Sets, White Multiplier Sets, Potato Onion Sets, Shallots, Top Onlon Sets. Market price; price variable.

\section{OKRA (气afran)}

The tender young pods are used for seasoning soups and stews. Sow the seed thickly, in rich soil, about the middle of May, in drills 3 feet apart, and cover the seeds

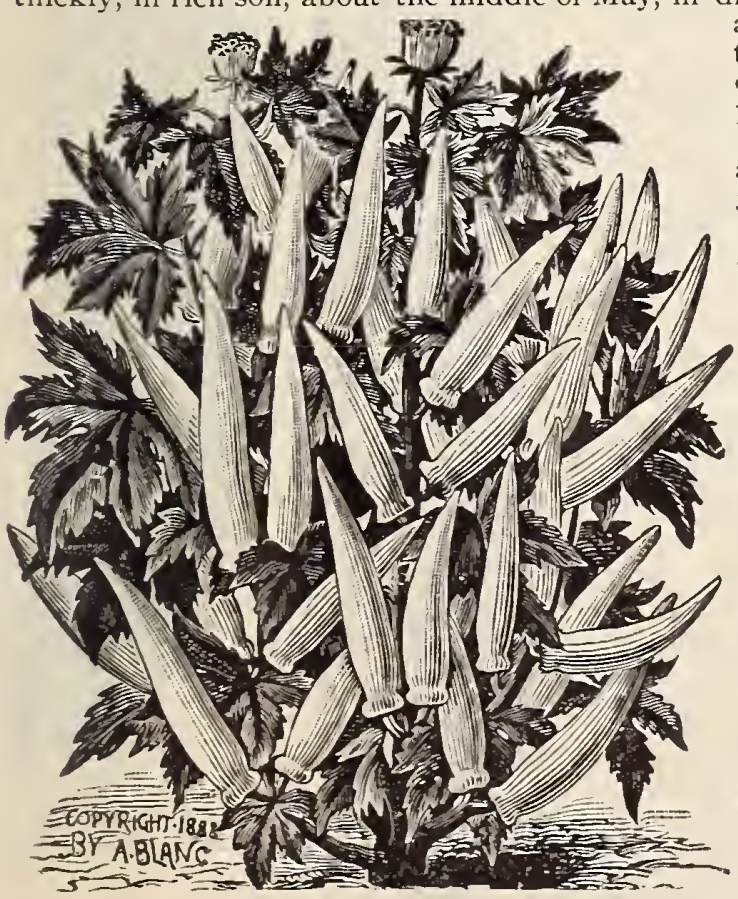

Uhite Telret Okra.

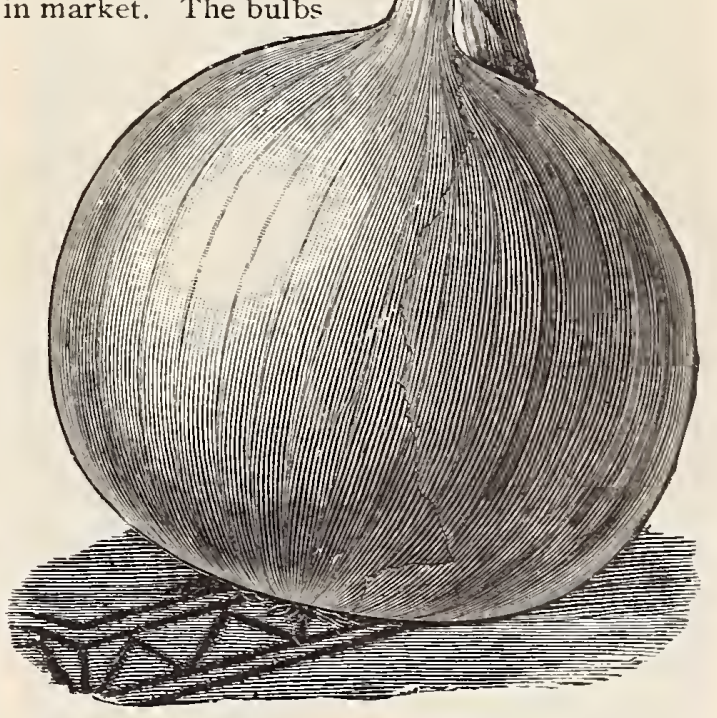

Spanish King, or Prizetaker. an inch deep. Thin the young plants
to stand Io inches apart, hoe them often, and earth up the stems a little in cultivation, for support. An ounce of seed will plant Ioo hills.

Improved Dwarf. Growing about I4 inches high, and producing twice as many pods as the taller sorts. The pods are smooth, tender and well-flavored. Oz. Io cts., $3 / 4 \mathrm{lb}$. 35 cts., lb. \$1.

White Velvet. Pods pure white, round and smooth, with no square edges or disagreeable prickles; also larger than in most sorts ; produced abundantly. Oz. Io cts., I/4 lb. 35 cts., lb. \$I.

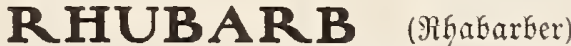

This plant is mostly propagated by division of the roots. The best time to set out the plants is early in the spring, although it is sometimes done in autumn. Make furrows of good depth, 3 or 4 feet apart, according to the variety planted; across these furrows at right angles, make others the same distance apart; at each intersection put 3 or 4 shovelfuls of good manure, and upon this set the plants. Any good soil will suit Rhubarb but to obtain heavy crops, good soil, well manured is indispensable.

Linnæus. The earliest and best for garden use; not as coarse and fibrous as the larger sorts. Oz. 25 cts., $1 / 1 \mathrm{lb} .65$ cts., $1 \mathrm{~b} . \$ 2$.

Victoria. The variety in general use for the market; yields immense crops. Oz. 25 cts., $1 / 41$ b. 65 cts., 1 b. $\$ 2$.

Roots of the above varieties, per doz. $\$ 1.50$; per $100, \$ 7$.

\section{PARSLEY (\$eteriilie)}

The leaves of most sorts of Parsley are beautifully curled, and useful for garnishing as well as flavoring. An ounce of seed will sow about I 50 feet of drill.

Dwarf Extra Curled. Dwarf, with finely curled leaves.

cts., $1 \mathrm{~b} .75 \mathrm{cts}$

Champion Moss Curled. Leaves bright green, finely cut and beautifully curled. Oz. Io cts., I/4lb. 25 cts., lb. 75 cts. 


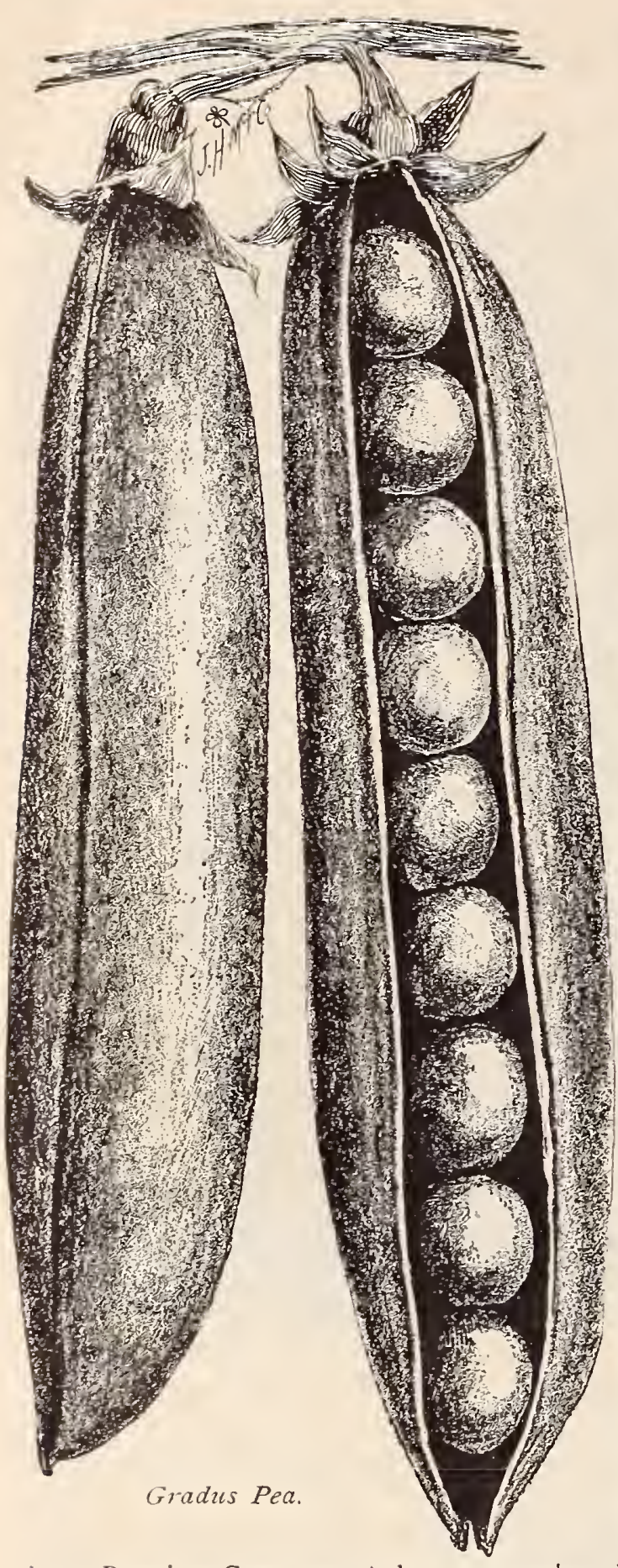

\section{Peas (ertion)}

All smooth-seeded Peas may be planted as early in spring as the soil can be prepared for them. They are very hardy, and will endure a low temperature, both befole and after sprouting. By sowing for the first crop as early as is practicable, and for succession at intervals of about two weeks until the first of June, a gond supply of this delicious vegetable may be enjoyed through the greater part of the summer. Late sowings, however, do not yield so well as early ones, because the hot and dry weather is unfavorable to the development of the plants. The seeds should be sown in drills about 3 inches deep and from 3 to 4 feet a part, according to the variety, taller sorts requiring more ruom than the dwarf ones. Dwarf Peas require a very rich soil, while tall ones thrive best in rather thin ground, which does not stimulate too luxuriant growth in the vines, to the detriment of the pods. The latter are frequently sown in double rows, with brush or support of some kind between them. Wrinkled Peas are not so haidy as the smooth sorts, and should not be sown so early, but are superior to them in quality, more delicate in flavor, and remain longer in season. One quart of seed will plant about i25 feet of drill.

For Peas to be sent by mali, add postage at the rate of 15 cts. per quart to prices given.

\section{EXTRA=EARLY PEAS Medium and Dwarf Sorts}

A $(*)$ indicates a wrinkled variety

The W. E. B. Co.'s Maud S. A favorite with the market-gardeners on account of its earliness and extreme productiveness, its vigor and vitality, often resisting a drought, and maturing a crop when ordinary sorts of earlies have failed. 2 feet. Qt. $25 \mathrm{cts}$., $1 / 2$ pk. $65 \mathrm{cts}$, bus. $\$ 3.25$

Ameer. Resembling Alaska in manner of growth, but a week to ten days later, the greatest difference being in the size of the pod, which is much larger and slightly curved. Seed green, smooth. Height $21 / 2$ feet. Qt. 25 cts, $1 / 2 \mathrm{pk} .85 \mathrm{cts}$., bus. $\$ 5.50$.

Aiaska. One of the earliest in cultivation; about 75 per cent of the pods can be gathered at the first picking. Vines 2 feet high; pods small, but well filled with plump, excellent dark green peas. Qt $25 \mathrm{cts}$., $\mathrm{t} / 2 \mathrm{pk}$. $65 \mathrm{cts}$, bus. $\$ 4$.

First and Best. Similar to Maud S. Early, prolific and uniform in ripening. Qt. 25 cts., $1 / 2$ pk. 65 cts., bus. $\$ 32 \mathrm{j}$

Sutton's Excelsior. New. (See page 3.)

Tom Laxton. A rival of the Gradus. Habits of growth identical witl Gradus. Pods are deeper, richer green, square at the end. A good yielder, where the Gradus is a little shy; quality fine. Qt. 35 cts., I/2pk. \$I.25, bus. $\$ 7$.

Gradus. New. This is undoubtedly the greatest advance ever achieved in Peas, for it is as early as the first earlies, with pods as large as the Duke of Albany and the same shape and color, each pod containing nine or ten wrinkled peas of true marrow flavor; altogether the most distinct and largest-podded early Pea ever raised. Stock this season limited. Qt. $35 \mathrm{cts}$. r/2pk. $\$ 1.25$, bus $\$ 7$.

Nott's Excelsior. The finest dwarf Pea in cultivation; robust and vigorous in growth; throws out laterals from the base of the stock, producing in profusion long, handsome pods, closely packed with large peas of fine flavor; more vigorous and prolific, with larger pods and more peas than either American WVonder or Premium Gem : sure to be very pular when generally known; seed green and wrinkled. in inches. 0 t $30 \mathrm{cts}, 1 / 2 \mathrm{pk} .85 \mathrm{cts}$, bus, $\$ 6$.

American Wonder. One of the earliest of wrinkled Peas; flavor and quality excel lent; vines dwarf and strong, io to 12 inches high; pods long and well filled; a favorite. Qt. $30 \mathrm{cts}, \mathrm{T} / 2 \mathrm{pk} .85 \mathrm{cts}$. bus. $\$ 550$.

McLean Premium Gem. Very early and superior dwarf wrinkled Peas, with vines wel hranched, and from I2 to I5 inches ligh ; pods very abundant. Peas tender, sweet and good. Qt. 25 cts., $1 / 2$ pk. 85 cts., bus. $\$ 5$

New Dwarf Champion. "Iessrs. Rogers Bros., who introduced this new variety, speak very highly of it. Qt. 25 cts., $1 / 2$ pk. 75 cts., bus. $\$ 4.50$

\section{INTERMEDIATE and LATE PEAS}

McLean's Advancer. Second early. Qt. 25 cts., ז/2 pk. 65 cts., bus. \$4.

Telephone. Pods and peas very large and showy, the latter being very sweet and rich ; very popular. Vines $3^{1 / 2}$ feet high. Qt. $30 \mathrm{cts}, 1 / 2 \mathrm{pk} .85 \mathrm{cts}$, bus. $\$ 6$.

Stratagem. Late English variety; large, showy pods. Qt. $30 \mathrm{cts}$., 1/2pk. $\$ 1$, bus. $\$ 6.50$

Shropshire Mero. Nedium early; heavy cropper. Qt. $25 \mathrm{cts}, 1 / 2 \mathrm{pk}$. $75 \mathrm{cts}$., bus. $\$ 4$.

Bliss' Everbearing. Large, well-filled pods. Qt. $25 \mathrm{cts}$, $1 / 2 \mathrm{pk}$. $75 \mathrm{cts}$., bus. $\$ 4$

Juno. A wrinkled, medium early Pea. Qt. $25 \mathrm{cts}$., 1/2 pk. 75 cts., bus. $\$ 4$

Champlon of England. A tall-growing, green, wrinkled marrow. Ot. $25 \mathrm{C}$., 1/2 pk. 65c., bus. $\$ 325$.

Black-eyed Marrow. For late crop. Qt. $15 \mathrm{cts}$., $1 / 2 \mathrm{pk}$. $40 \mathrm{cts}$., bus. $\$ 2.50$.

Mammoth Meiting Sugar. Best edible-podded Peas. Qt. $35 \mathrm{cts}$., $1 / 2 \mathrm{pk} . \$ 1.25$.

Canada Fleid. Used for fodder. Sown with oats. Bus. \$I 60

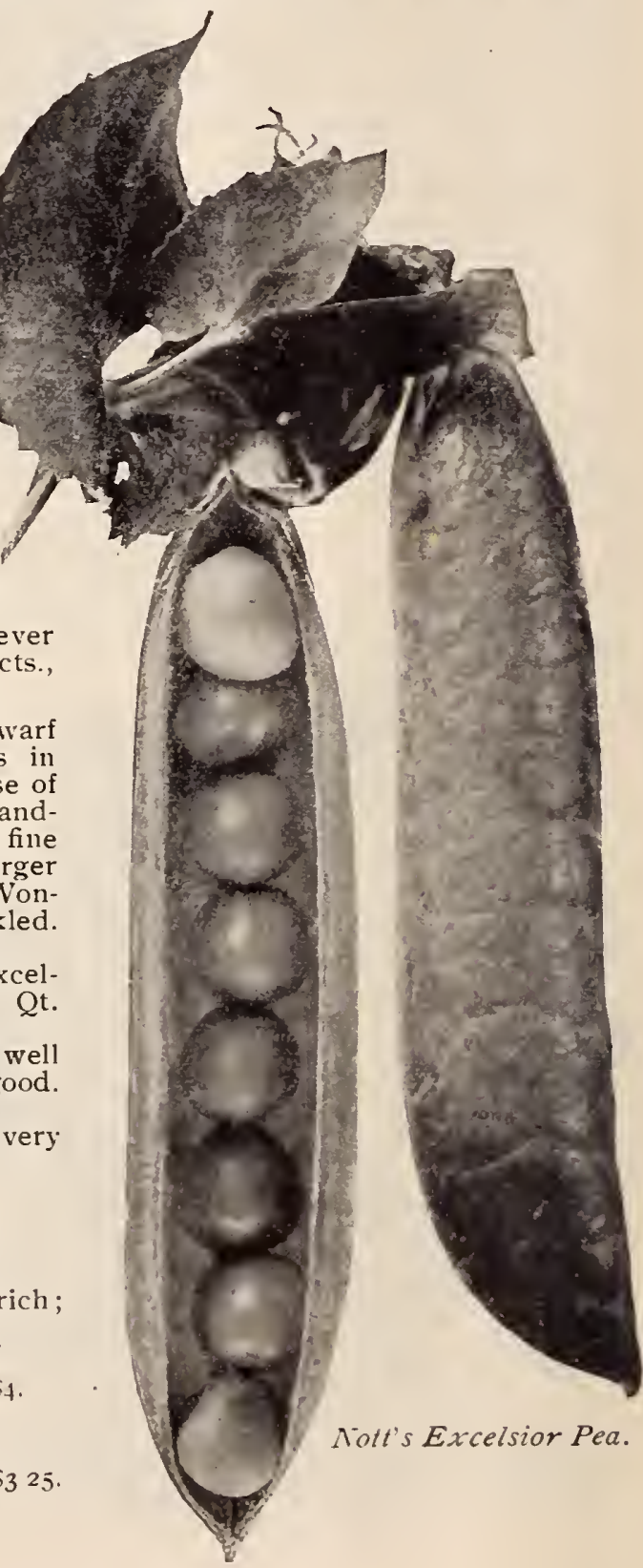




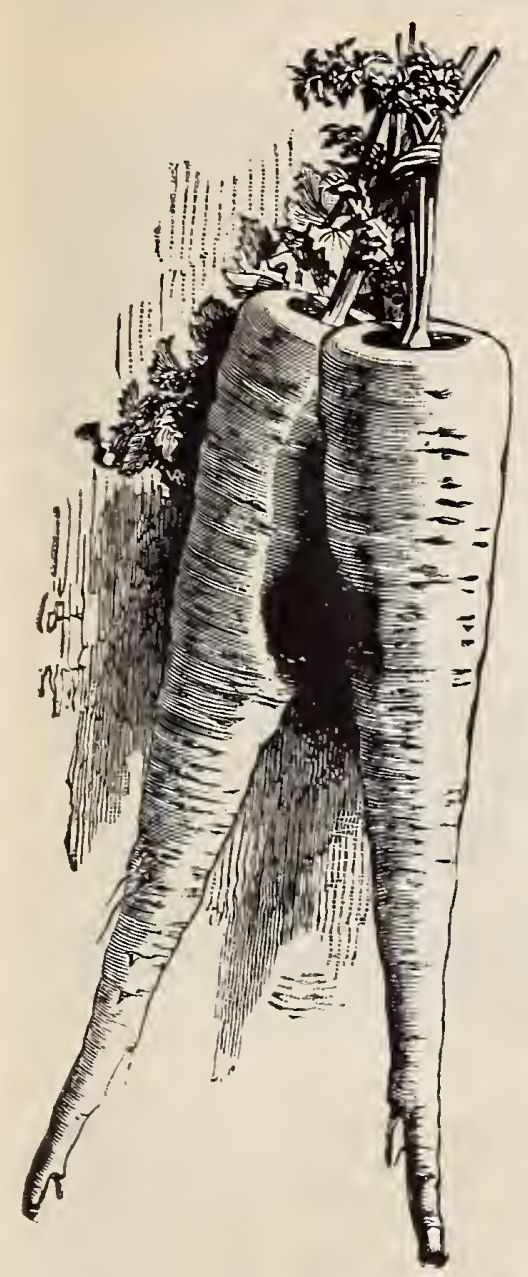

Improved Hollow Crown Parsnip.

\section{PARSNIPS}

\author{
( (a)tinafe)
}

Aside from its value as a table vegetable, the Parsnip also furnishes a healthful and nourishing food for stock, and is especially valued for this purpose by dairymen Sow the seed in drills 15 inches apart, as early as possible in spring, and thin the plants until they are 5 or 6 inches apart in the rows. The roots are improved by frost, and only enough for winter use need be taken up in the fall, leaving the rest in the ground until spring, to be dug up as required By running a plow, such as used for breaking sod, along one side of the rows, field crops of Parsnips will be thrown out so that they can be harvested easily. Deep, rich, heavy soil is best suited for the culture of Parsnips, but on any deep, rich, mellow soil the yield is good per acre, and the roots will be smootl and large if no fresh manure is used; this tends to make them coarse-grained and misshapen. An ounce of seed will sow I5o feet of drill; five pounds will sow an acre.

Improved Hollow Crown. The variety most widely cultivated. The roots are tender and sweet, and their yield per acre is heavy. Oz. Io cts., I/4 lb. $20 \mathrm{cts}$., 1b. $50 \mathrm{cts}$

Guernsey. The roots do not grow as long as those of the preceding, but are thicker and more easily gathered. A very heavy cropper; roots smooth; flesh fine-grained and of excellent quality Oz. Io cts., 1/4lb. 20 cts., 1 b. 50 cts.

\section{PEPPER}

\section{(}

Sow in hotbed as early as April, transplant to rich, warm, mellow soil as soon as the weather has become warm and settled, setting them about 2 feet apart in drills 3 feet apart Seed may be sown later, in the open ground, when all danger from frost is over, and thinned to the distance given above. The pods are used in making all sorts of pickles. An ounce of seed will produce 2,000 plants.

Chinese Giant. Grows very large and uniform, as early as Ruby King, and very mild. See p. 3. Oz. 40c., $1 / 4$ lb. $\$$ I. $25,1 b . \$ 4$

Large Be11, or Bu11 Nose. Widely grown, standard old variety, with very large, thick pods. Oz. 25c., 1/4 lb. $80 c ., 1 \mathrm{~b} . \$ 2.50$.

Ruby King. Bright red pods, about 5 inches long and 3 or 4 inches thick; mild and pleasant in flavor. Oz. 25 cts., $3 / 4$ lb. 80 cts.. lb. $\$ 2.50$.

Sweet Mountain. An early-fruiting sort; enormous mild-flavored pods, much used for mango making and mixing with salads. Oz. 25 cts., $1 / 4$ lb. 80 cts., 1 b. $\$ 2.50$.

Squash. The variety generally grown for pickling; medium size, thick skin; very productive. Oz. $30 \mathrm{cts}$., $1 / 1 \mathrm{lb}$. $80 \mathrm{cts}$., $1 \mathrm{~b} . \$ 2.50$

Golden Queen. Pods large, yellow; similar to Large Bell in shape, but milder flavored. Oz. 25 cts., 1/4lb. 80 cts., 1 b. $\$ 250$.

Long Red Cayenne. Pods long, slender, bright red, very sharp. Oz. 30 cts., $1 / 4 \mathrm{lb} . \$ \mathrm{I}, 1 \mathrm{~b} . \$ 3$.

Red Chili. Used for making Pepper-sauce. Pods small, conical, scarlet, pungent; plants very fruitful. Oz. $30 \mathrm{cts}$, , $1 / 4 \mathrm{lb}$. $\$ \mathrm{I}, \mathrm{lb}$. $\$ 3$.

Red Cherry. Pod small, round, bright red; ornamental. Oz. 30 cts., I// lb. $\$$ I, lb. $\$ 3$.

Celestial. Pretty, conical pods 2 or 3 inches long, thickly covering the plant. Creamy yellow, changing to bright scarlet, so that a plant full of fruit shows beautiful colored contrasts. $\mathrm{O} z$. $30 \mathrm{cts}$., $1 / 4 \mathrm{lb} . \$ \mathrm{I}, \mathrm{lb} . \$ 3$.

\section{RADISH ( (Rettig)}

Select a light, sandy loam, and sow as early as the ground can be worked in the spring For a successive supply sow every two or three weeks.

Vick's Early Scarlet Globe (American-grown). For forcing in the greenhouse, hotbeds or coldframes, and for sowing in open borders early in the spring, there is no other red variety so desirable. It is the earliest, its color is the handsomest, in flavor it is the mildest, most crisp, juicy and tender. It forms a small top, and will stand a great amount of heat. It is the market-gardeners' favorite forcing Radish. It will sell "three to one " compared with any round red sort. Oz. Io cts., I/41b. 25 cts., 1b. 75 cts.

French Breakfast (American-grown). Olive-shaped; red above and white below medium size; small top and of quick growth ; crisp, sweet and tender. Oz. IOc., $1 / 4 \mathrm{lb} .20 \mathrm{c}$., 1b. 6oc.

$\checkmark$ Long Scarlet Short Top (American-grown). Long, straight and smooth; tender while young; flavor delicate ; color bright red. Oz. Io cts., 1/1b. 20 cts., lb. 60 cts.

Ear1y Olive-shaped Scarlet. Olive-shaped; skin bright scarlet; flesh firm and crisp. Oz. Io cts., $1 / 4$ lb. 20 cts, 1 b. 60 cts.

Olive-shaped White. Has white, olive-shaped roots. Oz. Io cts., 1/4lb. 20 cts., 1b. 60 cts

Early Deep Scarlet Turnip. Skin deep scarlet; flesh sweet, tender, mild and crisp quick-growing, early variety; tops small. Oz. Io cts., 1/4lb. 20 cts., lb. 60 cts.

Beckert's Improved Chartier. The finest variety; as early as Long Scarlet Short-Top, but better in quality; superior to any other Radish. Oz. IOc., 1/41b. 20c., 1b. 6oc.

Wood's Early Frame. One of the best long varieties for forcing, also good for outdoor crops; tops small, flavor excellent; early. Oz. Io cts., 1/4lb. $20 \mathrm{cts}$., $1 \mathrm{~b}$. $60 \mathrm{cts}$.

Long Brightest Scarlet. Vivid scarlet, tipped with snow-white; rapid grower: qualitý fine. Oz. Io cts., $1 / 4$ lb. 20 cts., 1b. 60 cts.

Long Black Spanish. Roots black; flesh white and slightly pungent; one of the hardiest and latest. Oz. Io cts., I/4 1b. 20 cts., 1b. $60 \mathrm{cts}$

White Giant 8tuttgart. Very early, and grows to a large size. Fine quality, firm and btittle. Oz. Io cts., 1/4 lb. $20 \mathrm{cts}$., 1b. $60 \mathrm{cts}$.

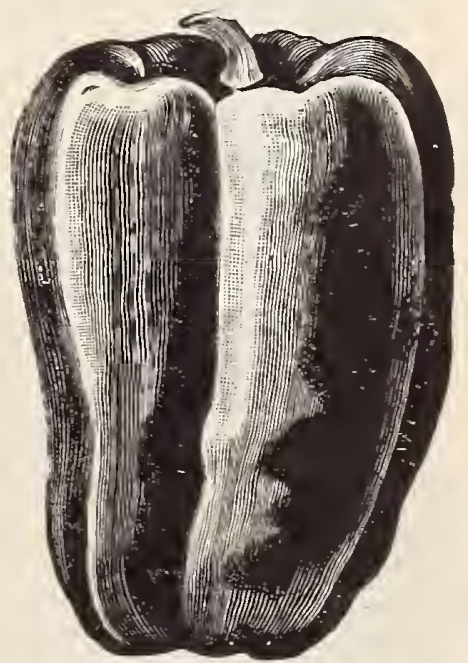

Large Bell, or Bulc Nose.

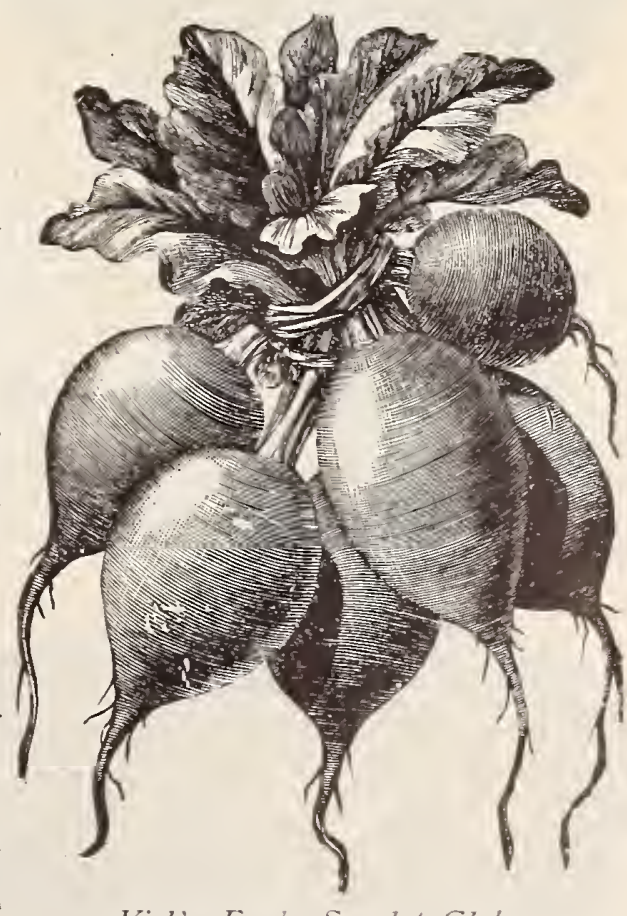

Vick's Early' Scarlet Globt. 
THE W, E, BARRETT COMPANY PROVIDENCE, RHODE ISLAND

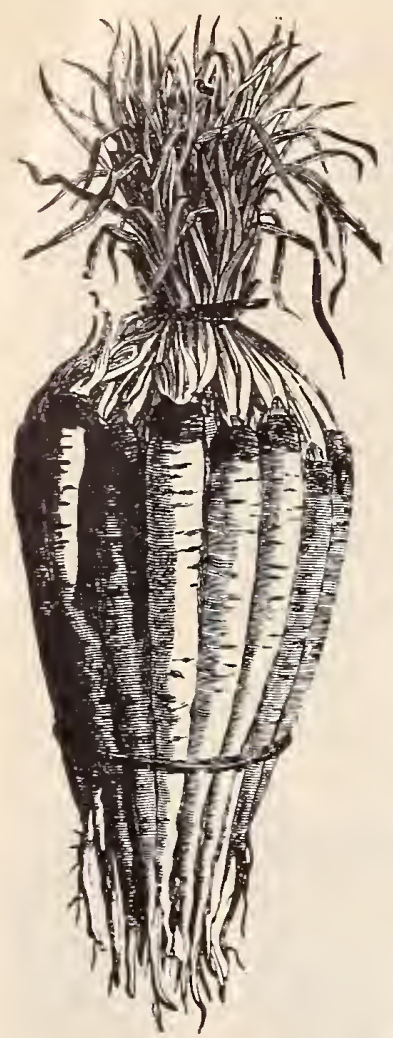

Salsify

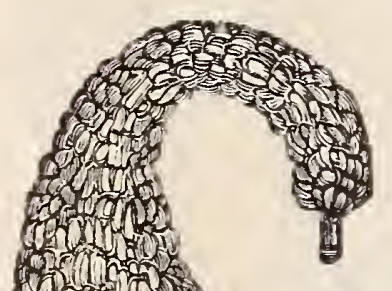

Squash seed should be planted at about the same time and in the same manner as cucumbers and melons. The hills should be 9 feet apart each way, slightly elevated and highly manured. Bush varieties.may be planted closer together. Use plenty of seed, as the bugs will destroy some plants. An ounce of seed will plant from 20 to 40 hills.

Chicago Warted Hubbard. This is a new type of the well-known Hubbard, produced by careful selection of the large, dark green, warted specimens always seen in good stocks of the Hubbard. It has been bred to this type until it is so fixed that nearly all have very hard, warty shells; are of large size and of the very est quality. This strain is popular with market men. Oz. $10 \mathrm{cts}, \mathrm{T} / 4 \mathrm{lb} .25 \mathrm{cts} ., 1 \mathrm{~b} .80 \mathrm{cts}$.

The Warren. This variety resembles Turban in shape; the shell, however, is rough and warty, and much thicker and harder than in that variety. The color is richer, the quality excellent, and it is a better keeper. Oz. Io cts., I/4lb. 25 cts., lb. 80 cts.

Dunlap Prolific IIarrow. An improved strain of Boston Marrow; fruits deeper orange, more rounded, thicker, having a smaller seed cavity and better flesh. A productive, good-keeping Squash. Oz.

Mubbard. A standard late Squash. Skin dark green; flesh fine-grained, dry, sweet, late-keeping. Oz. Io cts., 1b. 30 cts., 1b. $\$$ I

Golden Mubbard. This is a very distinct sort of the shape and general character of the Hubbard, but a little smaller, earlier to mature and of a rich orange-red color, instead of the dark olive-green of the old Hubbard. Oz. 10 cts., 1/41b. 25 cts., lb. 80 cts.

Delicious. Its color almost uniformly a green shade. For table use 110 Squash compares with it. Remarkably fine and compact grain, dry, sweet, and exceedingly rich in flavor. Oz. $15 \mathrm{cts}$., I// $1 \mathrm{lb} .40 \mathrm{cts}$., Ib. $\$ 1.25$. Faxon. The shell is unusually thin, and the flesh deep yellow, thick,
sweet and fine for pies. The Squashes vary in color from pale yellow to $\begin{array}{ccc}\text { Summer Crook- } & \text { sweet and fine for pies. The Squashes vary in color from pale yellow to } \\ \text { neck Squash. } & \text { green, mottled and striped with a lighter color. Oz. 10c., I/4lb. 25c., 1b.8oc. } \\ & \text { Bay State. Thick-shelled and thick-meated; a little smaller than }\end{array}$ $\begin{array}{ccc}\text { Summer Crook- } & \text { sweet and fine for pies. The Squashes vary in color from pale yellow to } \\ \text { neck Squash. } & \text { green, mottled and striped with a lighter color. Oz. 10c., I/4lb. 25c., 1b.8oc. } \\ & \text { Bay State. Thick-shelled and thick-meated; a little smaller than }\end{array}$ Essex Hybrid; flesh dry, fine-grained and good; a good yielder. Oz. Ioc., I/41b. 25c., 1b. 8oc.
Mammoth Chlli. Very large and nutritious, orange-colored fruits, which keep well all winter. The most profitable sort for stock feeding. Oz. I5 cts, I/4 1b. 50 cts., 1b. \$1.50.

Giant Summer Crookneck. The largest of the early Crooknecks, and as early as any; flesh tender and good, cooking quickly. Oz. Io cts., I/4 lb. 20 cts., lb. 60 cts.

Golden Summer Crookneck. Early and productive; fruits yellow, covered with watery excrescences, as in all this race; flesh fine-grained and rich. All the Summer Crooknecks are noted for their great size and fine quality. This one is also handsome in appearance. Oz. Io cts, I// lb. 20 cts., 1b. $60 \mathrm{cts}$

Winter Crookneck. A favorite late-keeping winter Squash, with yellow skin and sweet

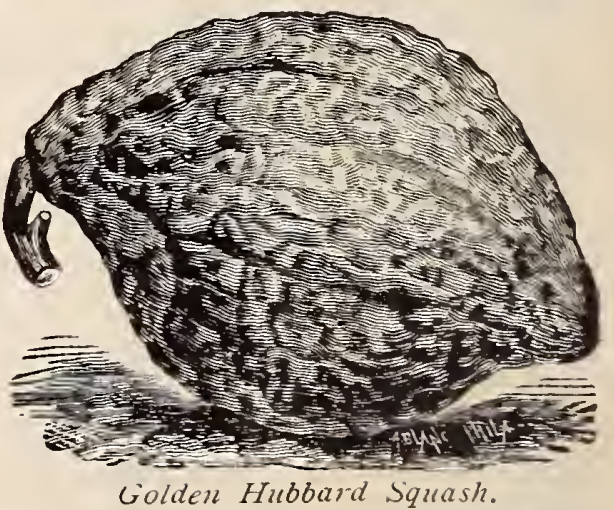
fine grained flesh. Oz. Io cts., $1 / 4 \mathrm{lb} .20 \mathrm{cts}, 1 \mathrm{~b}$. $60 \mathrm{cts}$

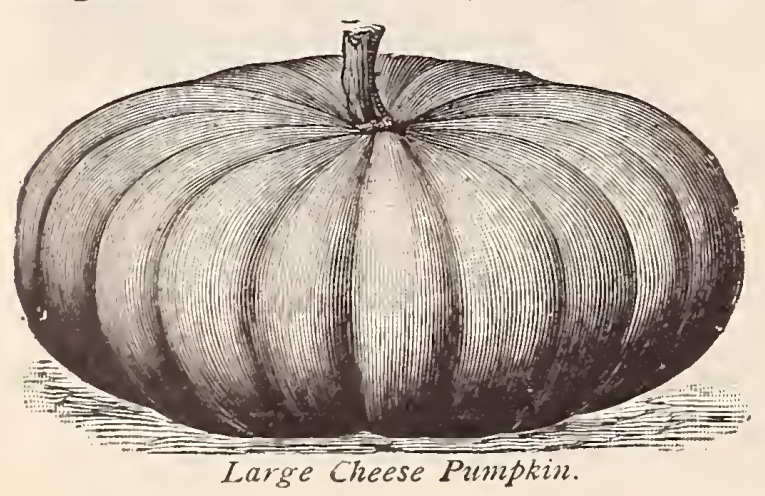

White Bush Scalloped. The earliest; skin crean-colored; flesh sweet and rich; very productive. Oz. 10 cts., $1 / 41 \mathrm{lb}$. $20 \mathrm{cts}$., $1 \mathrm{~b} .60 \mathrm{cts}$

Yellow Bush Scalloped. Differs from the above in color only. Oz. Io cts., $1 / 4 \mathrm{lb}$. $20 \mathrm{cts} ., 1 \mathrm{~b} .60 \mathrm{cts}$.

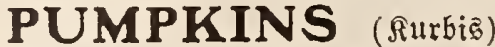

The Pumpkin is now little used except for agricultural purposes, the squashes being so much sweeter and drier and finer grained for the kitchen. The farmer, however, finds the Pumpkin a serviceable addition to his feed. The most common method of cultivation is to plant them with corn, two or three seeds to each hill.

Sugar. Round, not large, but very sweet, and an excellent table variety. Oz. Io cts., $1 / 4 \mathrm{lb} .20 \mathrm{cts}$, lb. $50 \mathrm{cts}$.

Mammoth. Grows to an immense size, oftell weighing over 100 pounds. Oz. 5 cts. $1 / 1 \mathrm{~b}, 50 \mathrm{cts}, \mathrm{lb} . \mathrm{t}, 50$

Connectlcut Fleld. Very productive; largely grown for feeding stock. (Per bushel, \$5.) Oz. Io cts., 1/4 lb. 15 cts., 1b. $30 \mathrm{cts}$. 


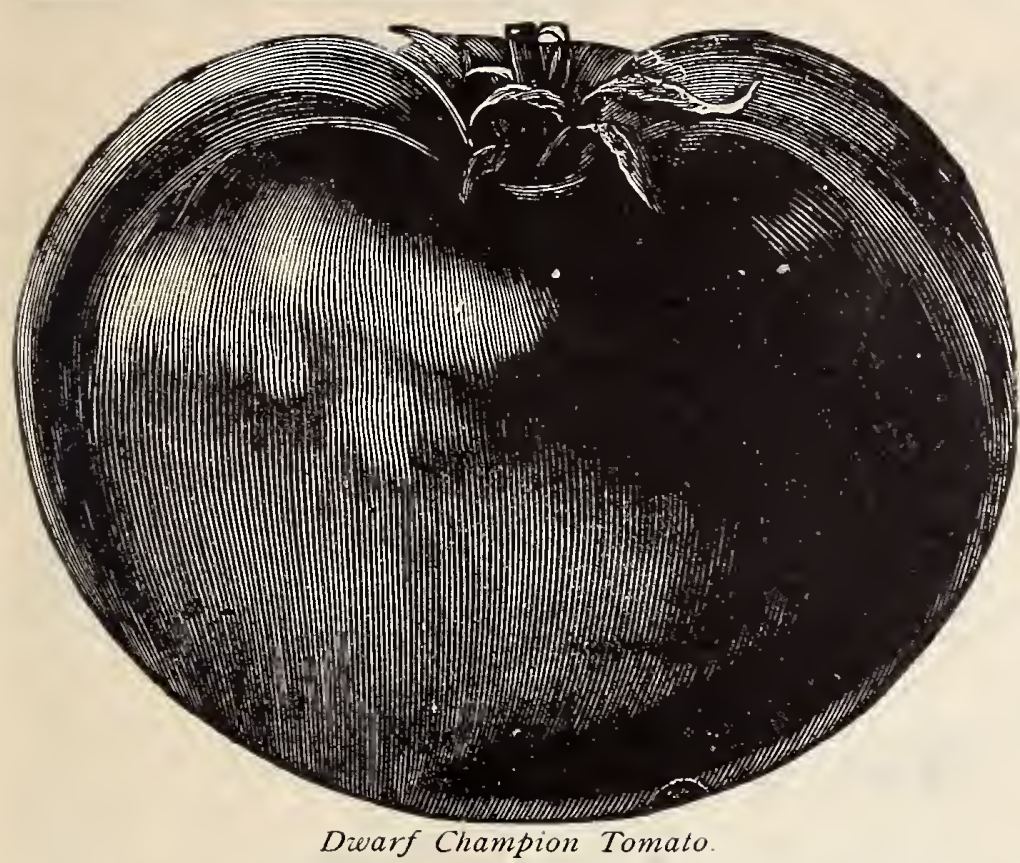

\title{
Tomatoes
}

\author{
(Eiebesäpjel)
}

For early use sow in February or March in hotbed or in boxes and pots set in the warm window, and hasten the germination and wrowth of the plants by good care and frequent watering. When the seedlings are about 3 inches high, transplant them to pots or in rows 4 or 5 inches apart, keeping the temperature at about 60 de grees. Subsequent transplantings will make them branching and stocky, but do not set them in the open ground until all danger from frost is past, then plant them in a warm, sunny place, and water them freely until they are well established. Some support which will keep the fruit above the ground and free from dirt should be given the plants. An ounce of seed will produce about 2,000 plants.

Earliana. This is considered the earliest red Tomato grown. Fair size, good shape, good quality. Oz. $40 \mathrm{cts}, 1 / 4 \mathrm{lb}$. $\$ 1.25,1 \mathrm{~b}, \$ 4$

New Dwarf Stone. A splendid new variety put out by Livingston, sure to come to the front as a general crop Tomato. See page 3. Oz 40 cts., $1 / 41 \mathrm{lb} . \$ \mathrm{I} .25, \mathrm{lb} . \$ 4$.

Lorillard. A splendid sort for forcing under glass, as well as for outdoor culture; bright, glossy red, smooth; of fine flavor and very early. Oz. $25 \mathrm{cts}$., $1 / 7 \mathrm{lb}$. $75 \mathrm{cts}$., $1 \mathrm{~b} . \$ 2.50$.

Atlantic Prize. The earliest; smooth, bright red and solid Oz. 25 cts., $1 / 41$ b. 75 cts., 1 b. $\$ 2.50$.

Dwarf Champion. This Tomato has grown rapidly in popularity since its first introduction several years ago, and is now one of the most valued early market sorts. It is quite distinct in foliage and habit of growth, the plants being compact, stocky and upright, and requiring no support. Although the fruits begin to ripen very early and the plants yield enormously, they do not flag before frost; many begin to ripen their crops July $\mathrm{r}$, hold half a bushel of fine Tomatoes when at their best, and still a peck or more of fruit can be gathered from such a plant when frost comes. The fruit is always smooth and handsome, ripening close to the core and never cracking; in shape and color it resembles Acme. Oz. 30 cts., $1 / 4$ lb. 85 cts., 1 b. $\$ 2.50$.

Beauty. One of the best. Fruit glossy crimson, large, smooth, solid, never cracking, and holding its size until late in autumn. Oz, $25 \mathrm{cts}$., $1 / 1 \mathrm{lb}$. $75 \mathrm{cts}$, $1 \mathrm{~b}$. $\$ 2$.

The Stone. This new variety bears very large, perfectly smooth fruits of bright scarlet; they are solid and meaty, with few seeds, and ship and keep well. One of the best sorts of recent introduction. Oz. $25 \mathrm{cts}$., $1 / 1 \mathrm{lb} 75 \mathrm{cts}$., $1 \mathrm{~b}$. $\$ 2$.

Chalk's Early Jewell. An extremely early variety of brightest scarlet color, deepfruited, very hardy and solid, with few seeds, and of excellent flavor. The popular early variety. Oz. 30 cts., $1 / 41 \mathrm{~b} .85 \mathrm{cts}$., $1 \mathrm{~b} . \$ 2.50$.

Acme. Fruit crimson, large, smooth, solid, never cracking, and holding its size well. Oz. 25 cts., $1 / 4$ lb. 75 cts., lb. $\$ 2$.

Magnus. Thicker and more solid than the Acme, ripens evenly, does not crack; a heavy cropper. Oz. 25 cts., $1 / 4$ Ib. 75 cts., 1b. $\$ 2$. Ib. \$3.

Yellow Plum. Fruits are yellow; used for preserves. Oz. $30 \mathrm{cts}$., 1/4b. \$I,

Grape, or Chorry Currant. Half an inch in diameter; desirable for pickles, etc. Oz. $30 \mathrm{cts}$.

Strawberry (Winter, or Ground Cherry). Small fruits enclosed in a husk: they have the flavor of strawberries, and may be preserved like plums. The vines are always heavily loaded with fruits. Oz. $30 \mathrm{cts}$.

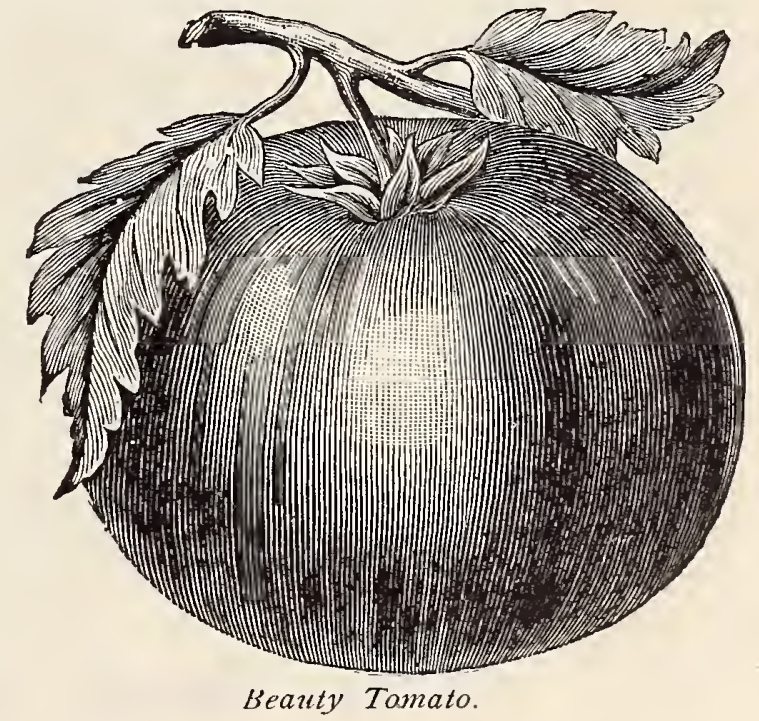

\section{The Best Turnip Seed}

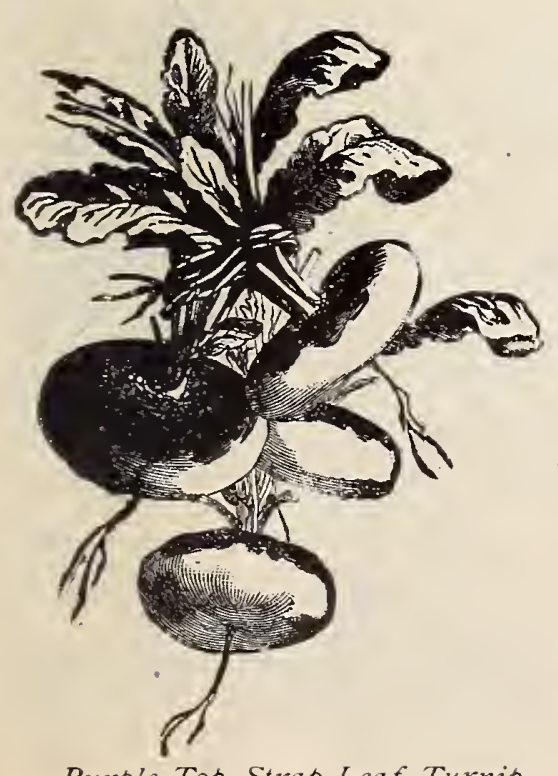

Purple-Tep Strap-Leaf Turnip.

For early, sow as soon as the ground can be prepared, in drills 15 inches apart, and thin the plants to stand 8 inches apart. Sow for succession at intervals of a fortnight until the last week in July, and from that time onward until the last of August sow for main crop. The sowings should always be made just before a rain, if possible, as the success of the crop depends in a great measure upon quick germination and rapid growth in the young plants. An ounce of seed will sow I5o feet of drill; one pound will sow an acre.

Twentieth Century Rock. New. This Turnip is now recognized as the standard winter Turnip. Oz. rocts., $1 / 4 \mathrm{lb}$. 30 cts., lb. 75 cts.

Early White Milan. Very early; pure white, and of fine quality. Oz. Io cts., $1 / 4 \mathrm{lb}$ $30 \mathrm{cts}, 1 \mathrm{~b} .75 \mathrm{cts}$.

Purple-Top Strap-Leaf. Grown largely for fall and winter crops. Oz. Ioc., 1/41b. 20c., Ib. 50c. Early Red-Topped Globe. Remarkable for its heavy yield peracre. Oz. Ioc., 1/1b. 20c, 1b. 50c

Early White Egg. Pure white, egg-shaped; grows rapidly and is fine-grained, sweet, delicate-flavored and solid Oz. In cts., 1/1 Ib $20 \mathrm{cts}$., 1b. $50 \mathrm{cts}$.

Golden Ball. Most delicate vellow-fleshed Turnip we know of. Oz. Ioc., 1/16. 20c., Ib. 5oc.

Cow Horn. 2 White, fine-grained, sweet flesh. Oz. Io cts., 1/41b. 20 cts., 1b. 50 cts.

Yellow Aberdeen. $\mathcal{V}$ Grown for stock-feeding; roots large and solid. Oz. IOc., 1/41b. 20c., 1b. $50 \mathrm{C}$ Large White Rock.V Quality extra fine; good keeper. Oz. Io cts., 1//1b. 20 cts., 1b.6o cts.

Budlong White Rock. $\checkmark$ Obtained by years of selection from the above, growing much smoother. Oz. Io cts., I//1b. 25 cts., 1b. $60 \mathrm{cts}$.

Improved American Rutabaga Large, firm, yellow roots, which keep well, are hardy and well flavored. Oz. Io cts., 1/41b. 20 cts., 1b. 50 cts.

Sweet Germant Large white; fine quality. Oz. Io cts., T/1b. $20 \mathrm{cts}$., Ib. $50 \mathrm{cts}$, 


\section{Sweet and Medicinal Herbs}

Anise (Anis). Used for garnishing and flavoring. The seeds have an agreeable and aromatic flavor, and are used in medicine.

Balm (Melisse). Leaves possess a fragrance similar to lemons. Made into Balm tea for fever, and into a beverage called "Balm wine."

Bası, Sweet (Basilienkraut). For stews, soups and sauces.

Burnet (Poterium). For salads and soups.

Caraway (Kümmel). The seeds are used in cakes, confectionery, etc.

Coriander (Koriander). Grown for its seeds, which are used in confectionery.

Dill (Dill). Used for pickling. Has an aromatic odor and a warm, pungent taste.
Hoarhound. Valuable for medicines.

Lavender (Wohlriechendespicke). Used for perfume.

Marjoram, Sweet. Used for seasoning.

Rosemary. An aromatic, ornamental herb.

Rue. Used for medicinal purposes.

Saffron. The flowers are used in dyeing.

Sage (Salbei). Medicinal, but used principally for flavoring.

Savory, Summer (Bohnenkraut). The dried stems, leaves and flowers are used extensively for flavoring.

Thyme. The young leaves and tops are used for sauces, soups and dressings. Also a good remedy for nervous headache when made into tea.

\section{Seeds for the Farm}

\section{FIELD BEETS}

White French Sugar. This variety is much grown in Europe for sugar-making; very sweet, and keeps well; much relished by stock. Oz. 5 cts., 1/4lb. I5 cts., 1b. 40 cts.

Mange1-Wurze1, Norbiton Giant. A long red variety, preferred by many to common Long Red, as it is considered of better keeping quality; good for deep soils. Oz. 5 cts., 1/4lb. I5 cts., 1b. 40 cts.

Mangel-Wurzel, New Golden Yellow Mammoth. The flesh of this variety is a bright golden yellow; of fine quality, and exceetingly rich in saccharine matter. Oz. 5 cts., $1 / 41 \mathrm{~b}$. 15 cts., 1b. $40 \mathrm{cts}$.

Mangel-Wurzel, Golden Tankard. A most important addition to our roots for feeding stock. Flesh a deep, rich yellow, very sweet and nutritious. In shape a little shorter than the Giant, but thicker. A very heavy cropper. By many this is ronsidered the best variety in cultivation. Oz. 5 cts., $1 / 4 \mathrm{lb}$. I $5 \mathrm{cts}$., $1 \mathrm{~b} .40 \mathrm{cts}$.

OUR FARM SEEDS AND IMPLEMENTS are kept thoroughly up-to-date and are among the best on the market.

\section{FIELD CORN}

Leaming. This is a dented flint variety. The ears are large, with deep, large grain, of dark orange color, and small red cob; stalks of medium size. Bus. $\$ 2$.

Early Yellow Canada. A very early 8-rowed variety; bears close planting, and yields numerous ears, which fill out to the extreme tip; a safe sort for high latitudes or late planting. Bus. $\$ 2$.

Early Sanford. Extensively used in various parts of New England, both for grain and as fodder and ensilage. It is of very luxuriant growth; very prolific; large stalk, with plenty of leaves, and handsome ears 12 inches long. Bus. $\$ 2$.

Longfellow. An excellent yellow variety for a main crop; ears long, sometimes I 2 to I 5 inches; large kernel and small cob; a sort safe to plant in this latitude; yields immense crops. Bus. $\$ 2$.

Rhode Island Whlte Cap. Well-known variety. Early, prolific; from this is made the celebrated Rhode Island white meal. Bus. $\$ 2$.

Ensllage and Fodder Corn. The IV. E. B. Co.'s "special" is selected stock of Blunt's Prolific, which not only grows a tall stalk, but said stalk has more leaves than other varietie-, because they grow nearer together on the stalk, making this a most desirable fodder Corn. Bus. market price.

\section{The Best Seed Potatoes, Northern:Grown}

(Fartof̈eln)

Our Potatoes are all choice, northern-grown stock, grown especially for seed. We send out no Potatoes in spring before danger from frost is past. Our prices will be as low as quality of stock will permit.

Irish Cobbler. One of the greatest producers among the first early varieties. Quality the best. Color a pure creamy white. Shape round to oblong. Vines very stocky; withstands drought remarkably well for an early variety.

Gold Goln. Fine-shaped tubers, rather oblong, white, russety skin. One of its best points is that about every potato is of good market size. Given a good chance it will return 300 or more bushels to the acre.

Norcross. See back of cover.

Snow. See back of cover

Early Fortune. A potato grower writes: "The Early Fortune is a grand success. plant $t$ d same day as Early Rose was, but ripened two weeks earlier."

W. E. B. Co.'s "Pride." A standard early sort, with such a combination of good qualitits as to make it a general favorite in this locality.

Green Mountaln. A late Potato which does well on all kinds of soil; very productive; oval in shape; a good keeper, and of fine quality.

New Queen. This is a very productive new seedling, and the best early market Potato ever sold in this country. In shape and color it resembles the Hebron.
Early Norther. A seedling from Early Rose, resembling it in shape and color; will outyield its parent 30 per cent. A strong, vigorous grower, of fine eating quality; well adapted to all soils and climates.

Delaware. Vines strong and vigorous; tubers very large, smooth, and of excellent quality. The color is white; an immense yielder.

"Carman No. 3." The best late variety ever grown. Has few and shallow eyes. The greatest yielder tver introduced. Yie:ds few, if any, small tubers.

Houlton Early Rose. We are prepared to furnish fine Maine and Prince Edward Island Early Rose in large lots at special prices.

Early Beauty of Hebron. Very rapid and vigorous grower, ripening a week ahead of Early Rose, which it far exceeds in great productiveness and excellence for table use, either baked or boiled. A good keeper; pure white skin; flesh rich and delicate.

Early Harvest. This is one of the most promising new kinds ever introduced. It is wonderfully early. This, together with early yield, superb quality and fine appearance, makes it a most valuable sort for first-early marketing or for home use. 


\section{Grass and Clover Seeds}

All our Grass and Clover Seeds are of the finest quality. Comparisons of samples and prices invited. For Special Lawn Mixture, see page 2.

\section{GRASSES}

For General Grass-seeding for Mowing Lands.

Sow Clover, Timothy and Red-Top mixed together. For one acre, eight pounds Clover, one-half bushel Timothy, one bushel Red-Top (chaff), or eight pounds Fancy Clear Red-Top.

Finest Mixture of Grass Seeds and Clover for Hay and Permanent Pastures

The importance to the farmer of a good selection and proper mixture of Grass seeds for the various purposes of cultivation, for mowing, for soiling, for permanent pasture, etc., cannot be over-estimated. We prepare a special mixture containing only the most suitable Grasses for permanent pastures and meadow lands, such as Orchard Grass, Meadow Foxtail, Sheep's Fescue, Rhode Island Bent, Meadow Fescue, English Rye Grass, Perennial Sweet Vernal, Red-Top and Clovers. Two to four bushels of this mixture is needed to seed an acre, according to the condition of the land.

Timothy, or Herd Grass (Plileum pratense). A well-known nutritious Grass, which on most soils will produce a better crop than any other variety. We offer a particularly choice sample of seed. Sow $1 / 2$ bus. per acre, if alone. 45 lbs. to bus.

Red-Top (Agrostis vulgaris). A valuable native permanent Grass, growing in almost any soil, moist or dry, and standing our hot climate. We received this seed in finest quality direct from the western growers. Sow 3 bus. per acre, if alone; it is generally sown mixed with Timothy, I $1 / 2$ bus. Red-Top and $1 / 4$ bus. Timothy. Io lbs. to bus.

Red-Top, Clean Seed. Chaff and weeds sifted out; extra fine.

Wood Meadow (Poa nemoralis). Well adapted for growing under trees and in shaded situations, Dwarf and fine-growing. Sow about 2 bus. per acre. I 4 lbs. to bus.

Rhode Island Bent (Agrostis canina). A fine, hardy, very compact Grass; very permanent, readily forming a heavy sward excellent for pasture. Sow 4 bus. per acre, if alone. Io lbs. to bus.

Kentucky Blue (Poa pratensis). Known as June-Grass. An early Grass of great value; makes a close, velvety turf, and is excellent for pasture; generally sown mixed with other Grasses. Sow about 3 bus. per acre, if used alone. Finest seed. I4 lbs. to bus.

Orchard (Dactylis glomerata). One of the earliest Grasses yields immense crops, and is excellent for pasture or hay; should be cut as it is coming into bloom, and it will produce a heavy second crop. One of the best Grasses. Sow 3 bus. per acre. I4 lbs. to bus.

Perennial Rye (Lolium perenne). An early, hardy and very nutritious Grass for meadows, pastures or hay crop. Generally used with other Grasses. If used alone, sow 2 bus. per acre. 24 lbs. to bus.

Meadow Fescue (Festuca pratensis). Of great value in mixtures for permanent pastures; of excellent nutritious properties, and is much relished by live stock. Sow $2 \frac{1}{2}$ bus. per acre. I5 lbs. to bus.

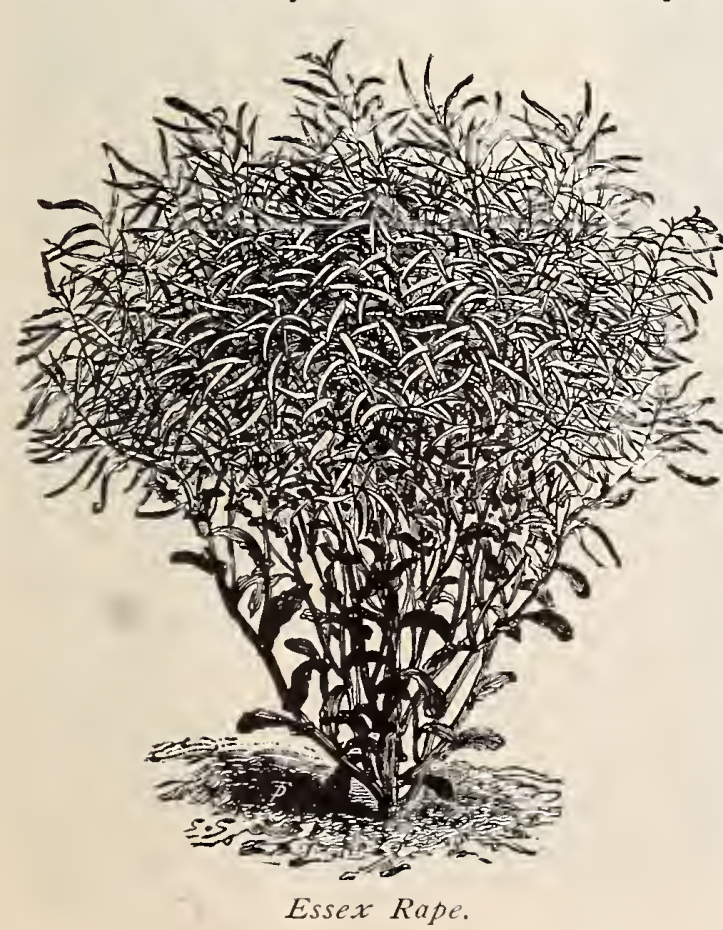

Crested Dog's T a il (Cynosurus cristatus). A perennial Grass much valued for its dwarf habit and hardiness. One of the finest Grasses for lawns. Sow 2 to 3 bus. per acre. 28 bs. per bus.

Tall Oat Grass (Aven a elatior). Succeeds well in pastures with other rasses; $m$ a kes plendid hay. Sow 4 bus. per acre. I3 bs. to bus.

Sweet Vernal Anthoxanthum doratum). Useful to mix with other Grasses for lawns in which it is inval able on account of its early growth and fragrant odor which it imparts to the other Grasses when drying • very hardy 'and permanent. I I lbs. to bus.

Meadow Foxtail (Alopecurus pratensis). Very valuable mixture for permanent pastures exposed to heat and drought; early and rapid in growth; not a valuable hay Grass. 8 lbs. to bus.

Sheep's Fescue (Festuca ozina). Of dense growth; excellent for dry situations and sheep pastures. Sow 21/2 bus. per acre. 12 lbs. to bus.

\section{CLOVERS}

All carefully cleaned and selected samples. Prices variable.

New York Clover (Trifolium pratense). Medium; finest quality. Mammoth, or Vermont Clover. Strong-growing; heavy cropper. Alsike, or Swedish (Trifolium hybridum). Luxuriant and sweet. White Clover (Trifolium repens). Excellent for lawns, as it remains green.

Lucerne, or Alfalfa (Medicago sativa). Bears heavy crops of forage; will stand cutting three or four times a season.

Crimson Clover (Trifolium incarnatum). An annual; will flourish well on poor soil, grows about 2 feet high; sown during July and August, often cuts Io tons of green fodder if cut from May I to Io.

\section{MILLET, or HUNGARIAN GRASS} Prices variable; subject to market fluctuations

Hungarian Grass (Panicum Germanicum). One of our best forage plants, and yields immensely, even when the weather is so dry that other crops dry up. One of the best annual Grasses for green fodder or hay. Sow from june I5 to July 3I. One bushel seeds all acre. 48 lbs. to bus.

Millet, Common (Panicum mitiaceum). An excellent forage plant; very early; 2 to 3 feet high; heads open, branching panicles. Sow I to I $1 / 4$ bus. per acre. 5o lbs. to bus.

Millet, German (Golden Millet). Of stronger and taller growth than other Millets, and does not inature so early. Sow I to I I $/ 2$ bus. per acre. 50 lbs to bus.

Japanese Barnyard Millet (Panicum crus-galli) This Millet is valuable as a green or dry fodder, or for siloing. It is erect in growth, very leafy, and the stalks are tender and succulent even when matured. The reported yield of green fodder is from I 5 to 20 tons per acre. For the most satisfactory results as a fodder crop this Millet must not be sown too thickly, as it stools very freely. On good soil, when sown early, Io to 12 quarts to the acre are sufficient. On poor soil, or if sown later sow 20 quarts.

Wild RIce (Zizania aquatica). A native of our northern and western states. Valuable as a forage plant for swamps and inun dated lands. Before sowing put the rice in coarse cotton bags, and sink them in water for 24 hours. Sow in water which is from 6 inclies to 5 feet deep, with soft mud bottom, or on low, marshy places which are covered with water the year round. In running water sow as much out of the current as possible.

Dwarf Essex Rape. Especially valuable for sheep pasturage; it is also recommended for hogs and cattle. Sow in April or August, in drills 2 or 3 pounds per acre, or 6 pounds broadcast. Dwarf Essex Rape is worthy of a trial, especially for autumn pasture in New England.

Kaffir Branching Corn, or Sorghum. Non-saccharine, but distinctly different from all others of that class. The plant is low, stocky, perfectly erect. It does not stool from the root, but branches from the top joints. The whole stalk, as well as the blades, cures into excellent todder.

Soja hispida (Soja Bean). Resembles a bean; the haulm is stiff, the pods are produced in clusters of from two to five, and each contain four smooth, oval, nankeen-colored seeds. This plant is said to thrive well in hot and dry weather. Very valuable for the south, for either man or beast.

\section{MISCELLANEOUS SEEDS Market Price}

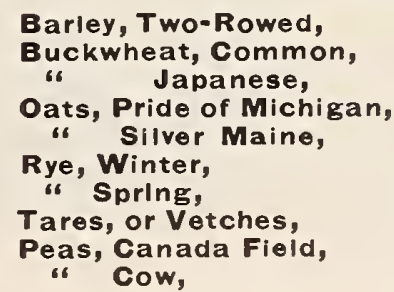

Barley, Two-Rowed Buckwheat, Common, Oats, Pride of Michigan, Silver Maine, " "Cow,

\author{
Wheat, Winter, \\ i6 Spring, \\ Rape, Dwarf Essex, \\ Sunflower, \\ Russian Hemp, \\ Sicily Canary, \\ German Rape, \\ Unhulled Rice, \\ Flax, \\ Parrot Seed, Mixed.
}




\section{SELECT FLOWER SEEDS}

In the following pages we offer a careful and choice selection of fresh and pure Flower seeds, including the best old and new varieties. No need of the flower garden has been neglected, for seeds of plants adaptable for every ornamental purpose, covering the whole range of form and color, height and habit, and the whole season with their bloom, may be found here.

\section{DISCOUNT ON FLOWER SEEDS BY MAIL}

Our liberal discounts or premiums on Flower Seeds in packets (purchaser's selection) reduce the cost to wholesale prices. These discounts are given only on seeds sold in packets, for which in all cases the cash must accompany the order.

We prepay postage on all Flower Seeds in packets and ounces.
This discount does not apply to assortments or collections, nor to seeds For $\$ I$, Select Seeds amounting to For $\$ 2, "$ " For \$3,

\section{by the oz. or 16 .}

\section{Orders by Mail}

Promptly Forwarded.

\section{Choice Annuals for Bloom the First Season}

\section{A STERS}

\section{Choicest New and Old Varieties}

The Aster is a royal annual, glori fying the garden with a rich display of bloom until the chrysanthemum, for which it is a fitting forerunner, begins to open its buds. The different forms are grown in gardens everywhere. Our collection includes the most distinct and beautiful forms and varieties of -ich colors. A good selection will give elegant flowers for cutting from July until frost.

COMET. Flowers large and perfect in shape; petals long, wavy and twisted, suggestive of a Japanese chrysanthemum. The flowers, which a re very handsome, average from 3 to 4 inches across, and are borne thickly on pyramidal plants from I2 to I5 inches high. Pure White, Carmine, Rose, Light Blue and Mixed. Each, Io cts. per pkt.

BEMPLE'S BRANCHING. A choice strain, which by careful selection has been brought to a high degree of perfection. Plant of branching habit, producing from to to 20 large perfect flowers. White, PInk and Lavender. Io cts. per pkt.

LARGE - FLOWERING VICTORIA Immense, showy flowers, perfectly double to the center, with regularly overlapping petals; distinguished in appearance and excellent for cutting. The plants form pyramids I 8 inches high, and carry 15 to 20 flowers. White, Azure Blue, Peach Blossom, Rosy Carmlne, Crimson, Dark Blue and Mixed. Each, Io cts. per pkt.

PEONY-FLOWERED PERFECTION. Peerless in form, size and the rich and delicious colors of its flowers. Snow-White, Bril= llant Rose, Crimson, Light Blue and Mixed. Each, io cts per pkt.

MaCON. Flowers elegant in shape, and especially useful for cutting; in form and habit the plants somewhat resemble the Vic toria race, but bloom more freely. Pure White, Rose, Crimson and Mixed. Each, Io cts. per pkt.

\section{ABRONIA}

Pretty trailing plants, with prostrate branches, and clusters of sweet-scented flowers, somewhat like verbenas. For baskets, rock work and borders; of easy culture, blooming profusely.

A. arenaria. Bright waxen yellow flowers. 5 cts. per pkt.

A. umbellata grandiflora. Very large, fine clusters of pure rose. 5 cts. per pkt.

\section{ADONIS}

Showy, free-blooming plants, about a foot tall, with feathery foliage and large, brilliant flowers, appearing in early spring and lasting a long while.

A. autumnalls (Pheasant's Eye). In tense dark red, with black center. $5 \mathrm{cts}$. per pkt.

A. vernalls. See Perennials. 5 cts per pkt.

\section{AGROSTEMMA}

(Rose Campion)

Exceedingly pretty and graceful Howers. Red, white, and red and whit Howers. 5 cts. per pkt.

\section{AGERATUM}

These are greatly valued for bed ding on account of their neat, vigorous growth and free-blooming habit. They bloom the whole sumner through, where sown early.

A. Lasseauxl. Fine clusters of bright rose, borne long and abundantly valued for cutting. $5 \mathrm{cts}$. per pkt.

A Mexlcanum, Littlo Dorrit, Dwarf Bluo. Flowers bright blue; the plant is very dwarf, free-blooming and handsome. 5 cts. per pkt.

A. - Dwarf White. Large clusters of flowers; habit like above. $5 \mathrm{cts}$ per pkt.
Comet Asters.

\section{ALYSSUM, SWEET}

i great favorite for bouquets and house culture, as well as for outdoor baskets and border edgings.

A. Bentham (maritimum). Trailing; flowers white, very sweet. 5 cts. per pkt.

A. compactum erectum (Little Gem). Very dwarf and spreading, covering a wide circle thickly with its white flowers, which appear when the plants are small. $5 \mathrm{cts}$. per pkt.

A. saxatlle compactum. See Perennials.

\section{BRACHYCOME IBERIDIFOLIA}

(Swan River Daisy)

Flowers light and graceful, and borne profusely ; colors blue or white, with dark center. Plants spreading in liabit, about a foot tall. Mixed, 5 cts. per pkt.

\section{BARTONIA AUREA}

Handsome, with downy foliage; fragrant, large golden yellow flowers, which open in the evening. Thrive in any soil; height about 3 feet. 5 cts. per pkt. 


\section{SUPERB BALSAMS}

(Lady's Slippers)

Popular and easy to grow; give brilliant masses of beautiful flowers for little care. Plants about 2 feet in height ; transplanting dwarfs them and makes the flowers more double. Some are as double and perfect as camellias; they range through all dark, rich, brilliant and delicate colors.

Double Rose-Flowered. Flowers very large, double, and of perfect form. Fine mixed. 5 cts. per pkt.

Improved Camellia-Flowered. Regular and perfect; large and full to the center. Separate colors, and choice mixed. Each, ro cts. per pkt.

Florists' Best Double White. ro cts. per pkt.

Mixed Double. All kinds and colors. 5 cts. per pkt.

\section{CALENDULA}

(Pot Marigold)

Produces a bright and constant mass of color; grows well anywhere, and flowers until frost.

C. officinalls grandiflora fl. pl. Semidwarf plant; handsome double pure golden yellow flowers. The best Marigold in cultivation; flowers very large and brilliant. $5 \mathrm{cts}$. per pkt.

Prince of Orange. Rich flowers of deep orange, striped with a lighter color large and very double. $5 \mathrm{cts}$. per pkt.

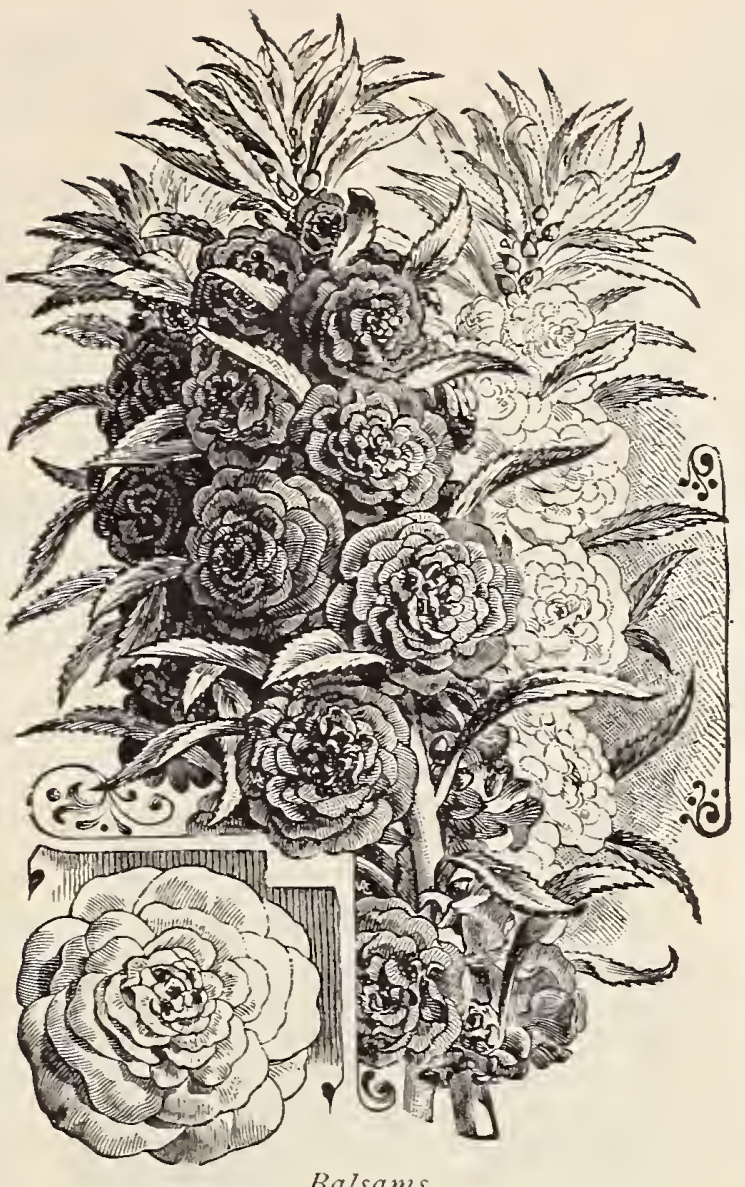

Balsams.

THE CROZY CANNAS

New Dwarl Large-Flowering French

For rich effects in bedding, the Dwarf French Cannas have now few rivals in popular estimation. As pot-plants or for winter-flowering they are also favorites. The seed should be soaked in hot water eight or ten hours before planting, and started early in hotbeds or in the house.

FIne Mixture of choice seeds, from dwarf, early-flowering plants. Ioc. per pkt.

\section{CLARKIA ELEGANS}

Early and profuse-flowering. Plants average $1 \frac{1}{2}$ feet in height; oddly formed double flowers are bright rose, purple or white.

Single and Double. Each, 5 cts. per pkt.

\section{CELOSIA, or COCKSCOMB}

For Beds and Borders, Pot Culture and Winter Bouquets

Odd and handsome. The comb-shaped heads often attain enormous size and are always gaily colored. The plants produce finer and brighter-colored flowers if given rich soil. The dwarf varieties are much used for pot culture, and are picturesquely odd and striking in appearance; deservedly popular everywhere.

Dwarf Yellow. Splendid, brightly colored heads of large size and fine form; plants strong, and but about 9 inches in height; very handsome. $5 \mathrm{c}$. per pkt. Empress. One of the handsomest; the rich crimson heads are enormous, yet quite shapely; plant no taller than the above. $5 \mathrm{cts}$. per pkt.

\section{CALLIOPSIS, or COREOPSIS (Bright Eyes)}

Gay and beautiful ; of graceful habit, easy culture, and flowering profusely throughout the season. As popular for cutting as for garden culture.

C. tinctoria. Flowers double, of a rich golden yellow color, with wine-maroon spots. 5 cts. per pkt.

c. Drummondil (Golden Wave). Pure bright yellow flowers, with an eye of rich, velvety brown. Compact and bushy, and blooms freely. 5 cts. per pkt.

\section{CACALIA COCCINEA (Tassel Flower)}

Loves a rich, sunny spot, where they bloom until late autumn. The tassel-shaped flowers are bright scarlet and borne in graceful clusters. 5 cts. per pkt.

\section{COLLINSIA}

Brightly colored flowers, blooming in whorls, several of which cluster about each stem. Plants continually in flower; $\mathrm{I} / 2 \mathrm{z}$ feet. Mixed, $5 \mathrm{cts}$. per pkt.

\section{COSMOS}

Fine for cutting ; long, slender stems, airy, graceful flowers and feathery foliage. Plants tall and strong-growing, from 4 to 6 feet high, and a perfect fountain of bloom from September until frost. Should be started early.

White Pearl. Large, snow-white flowers. 5 cts. per pkt.

Large-Flowering Pink and LargeFlowering Crimson. Each, 5 cts. per pkt.

Grand Mixture. Monster flowers with frilled petals, with large, round, open petals, with irregular, laciniated petals: white flowers, flecked and clouded with pink; shaded light and dark; beautiful shades of red and crimson; star-like flowers, with fringed edges, pink, white, red, in endless combination. 5 cts. per pkt.

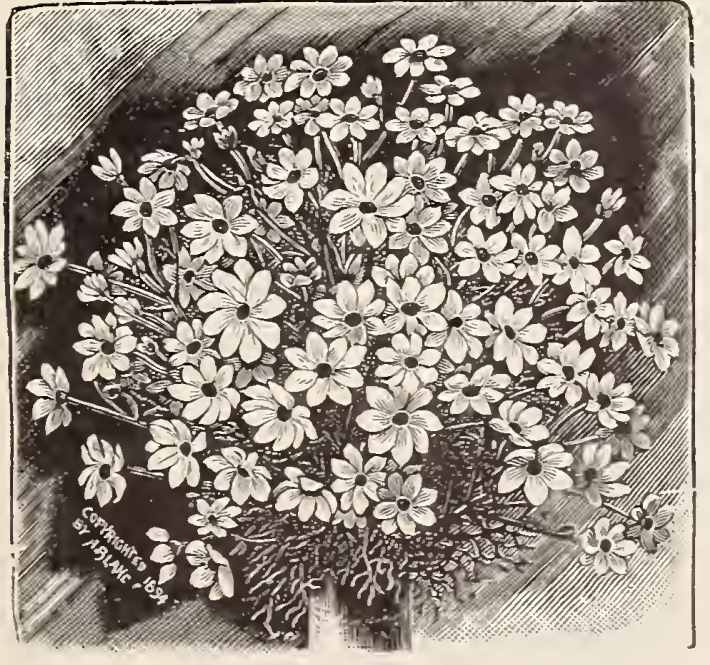

Cosmos.
Glasoow Prize (President Thiers, Tom Thumb). Quite dwarf and distinct ; plants a foot high; combs fine, deep crimson. 5 cts. per pkt.

Japonica. Tall, pyramidal; flower-heads of very rich, bright scarlet. 5 cts. per pkt.

\section{CENTAUREA CYANUS (Cornflower)}

Favorite old-fashioned flowers. The quaintly pretty flowers have good stems and are brightly colored. Flowers white or blue; plants about 18 inches tall, free-blooming. $5 \mathrm{cts}$. per pkt.

\section{CARNATIONS}

\section{Annual Forms, Blooming Soon after the Seed is Sown} MARGARET CARNATION

This new form of the hardy Carnation blooms four months from ed. Is much admired and valued in all gardens where it has been tested. Plants vigorous, semi-dwarf and neat, and if sown under glass in March or April, begin blooming in early summer and yield a brilliant display of flowers until frost. Plants which have bloomed all summer in the garden are frequently potted for winter decoration, and bloom in the window for a long time. Flower large, quite double and perfectly formed never bursting the calyx, and shrw all colors and variegations through beautiful shades of red, pink and white. Fine for cutting; stems are good, and the
flowers are produced in great profusion. Pure White, Rose, Scarlet, Vlolet and Mixed. Each, Io cts. per pkt.

\section{CHRYSANTHEMUMS}

\section{c. Carinatum fl. pl. Summer-bloom}

The majority of the flowers are
double and bronzy yellow, tinge
red or rose, but some will be pure
or crimson, and of graceful semi-

form. 5 cts. per pkt. 


\section{DIANTHUS}

\section{Brilliajt and Popular Garden Pinks}

Gay and spicily fragrant flower, well loved and grown everywhere, in almost any soil, and covering its dense thicket of leaves

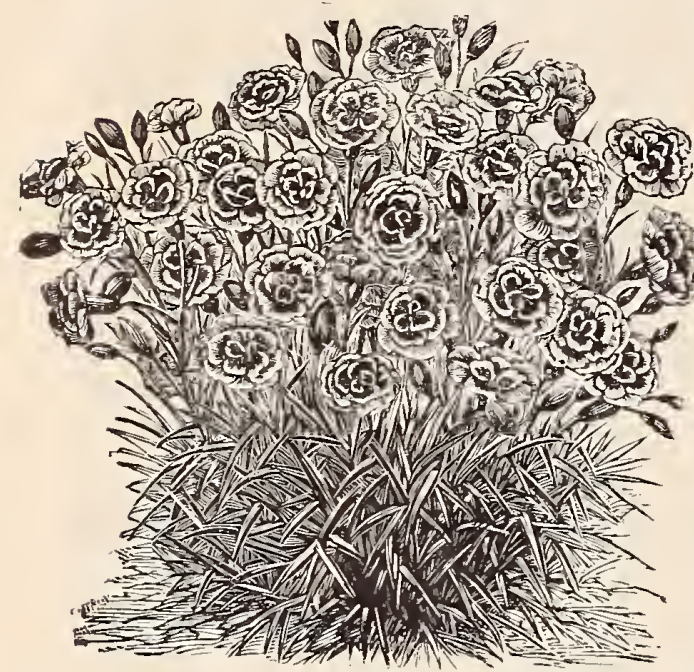

Dianthus. and stems with brilliant masses of flowers. All the varieties named below bloom the first year from seed.

D. Chinensis fl. pl. (Double Chinese, or Indian Pink). Flowers large and very double, in all rich colors. Fine mixed, $5 \mathrm{cts}$.

D. Heddewigll grandiflora fl. pl. (Crown of Perfection). Flowers of immense size and very double; produced in greatest profusion. A great diversity of colors, from purest satiny white to intense red, soft pink and flesh tints, and a large proportion of flowers marked in various hues. 5 cts.

D. - Eastern Queen. A very beautiful rose variety. Ioc. per pkt. D. - Crimson Belle. Splendid brilliant dark red. $5 \mathrm{cts}$. per pkt. D. - The Bride. White, with purple center; very pretty. $5 \mathrm{cts}$. D. - dladematus fl. pl. (Double Japanese, or Diadem Pink). Flowers large and fine in form and very double, yet ranging through all colors. Finest mixed, $5 \mathrm{cts}$. per pkt.

D. Imperialis fl. pl. (Double Imperial Pink). An extra-fine mixture, producing all colors of these handsome flowers. $5 \mathrm{cts}$. per pkt. Đ. barbatus (Sweet William). See Perennials.

\section{DAHLIA}

Dahlias grown from seed bloom the first year. A large percentage of the double varieties come true, while the single are superb giving flowers of most beautiful form and coloring, combined with graceful habit. The seed must be started early.

Mixed SIngle. Seeds saved from the best named varieties. Iocts. Mixed Double. Extra-fine mixed; will produce a large proportion of double flowers, including bright and rich colorings. Io cts.

\section{ESCHSCHOLTZIA CALIFORNICA \\ (California Poppy)}

Brilliantly colored and poppy-like, shining with a silken luster in the sunshine. A bed of them is fairly dazzling, with its rich hues of orange, pure yellow, scarlet, creamy white, crimson and carmine. Single and double. Each, 5 cts. per pkt.

\section{GAILLARDIA (Blanket Flower)}

Showy bedding plants, averaging about 2 feet in height, and covered with flowers from midsummer until frost.

G. picta Lorenziana. Double flowers, in many bright colors. 5 cts. per pkt.

c. grandiflora. See Perennials.

\section{GODETIA}

Bright and attractive little plants, compact and branching in habit, and always garr with a crop of pretty white, rose or crimson flowers. Mixed, 5 cts. per pkt.

\section{HIBISCUS AFRICANUS}

Showy and effective. The large, cream-colored flowers have a rich, dark brown center; the plants grow about 2 feet tall. $5 \mathrm{c}$. per pkt.

\section{IBERIS, or CANDYTUFT}

An old and universal favorite, largely cultivated, and continually in bloom ; as valuable for cut-flowers as for edging and masses, and always desirable.

1. amara. Clusters of pure white. $5 \mathrm{cts}$. per pkt.

Empress. Large, handsome trusses of pure white flowers; plant strong, and of candelabrum-like habit. $5 \mathrm{cts}$. per pkt.

Tom Thumb. Very dwarf, forming a low, dense mass of green against which the large clusters of white flowers show finely. 5 c. per pkt.

\section{LUNARIA BIENNIS (Honesty)}

Hardy biennial, and must be sown in autumn or early spring for flowers the first year. Flowers white and double. $5 \mathrm{cts}$. per pkt.

\section{LINUM GRANDIFLORUM RUBRUM (Scarlet Flax)}

Of great beauty; free-flowering and easy to grow. Blossoms bright scarlet, stems and foliage fine. $5 \mathrm{cts}$. per pkt.

\section{LUPINUS (Sun Dial)}

Grows about 2 feet tall; very effective in mixed borders. The seed should be sown where the plants are to stand. Mixed, 5 c. per pkt.

\section{LOBELIA ERINUS}

The Erinus forms of Lobelia are quite showy and free-blooming. The dwarf forms are used for edgings, vases, etc., other sorts for beds. All are of easy culture.

L. ErInus (Crystal Palace Speciosa). Ultramarine-blue. Trailing. 5 cts. per pkt.

L. - speclosa superba. Dark blue, with white eye. Trailing. 5 cts. per pkt.

L. - gracilis (light blue) and albus (pure white). Trailing. Each, $5 \mathrm{cts}$ per pkt

L. compacta varieties: Albus (pure white), Crystal Palace compacta (dark blue), and Prima Donna (rich crimson). Each, Io cts. per pkt.

\section{LARKSPUR}

Rocket Larkspurs, which bloom the first season if sown early, are very showy. Flower-spikes of bright colors. For others, see Perennials.

Dwarf Double German Rocket. All colors mixed. 5c. per pkt. Tall Double German Rocket. All colors mixed. 5 cts. per pkt.

\section{MATRICARIA CAPENSIS FL. PL。} (Double White Feverfew)

For cutting and pot culture, as well as for beds and borders. Thrives well in all soils; blooms until frost. Flowers pure white, double. 18 to 20 inches tall 5 cts. per pkt.

\section{MARIGOLD}

\section{(Double French and African)}

Showy plants for midsummer and autumn bloom. I to 2 feet tall, free-Howering and easy to grow.

Eldorado. Finest of the double African Marigolds. Flowers from Io to 14 inches across, very double, of bright golden orange and prim rose shades. $5 \mathrm{cts}$. per pkt.

Tali Double French. Mixed, producing flowers of various bright

Dwarf Double French. Plants low and compact. Mixed, 5 cts. per pkt.

\section{MALOPE GRANDIFLORA (Mallows)}

Robust branching plants, usually about 2 feet high, with large, mallow-like red or white flowers; very pretty. Mixed, 5 c. per pkt.

\section{MIGNONETTE}

The matchless perfume of this modest flower renders it one of the most popular annuals grown. In form and color the flower-spikes have been greatly improved, but it is for their delicate, subtle fragrance that they will always be chiefly valued for garden and window culture, and for the costliest as well as the simplest bouquets.

Deflance. New; specially adapted for pot culture. Io cts per pkt. Machet. The best variety for pots; is dwarf and free-blooming; flower-spikes beautiful, bright reddish maroon; very sweet. 5 cts. per pkt.

Large-Flowering. The old and well-known Mignonette, still as sweet as any. $5 \mathrm{cts}$. per pkt., $20 \mathrm{cts}$. per oz.

Gabrlelle. Very pretty sort, bearing large spikes of red flowers. $10 \mathrm{cts}$. per pkt., $50 \mathrm{cts}$. per oz.

\section{MIRABILIS JALAPA (Four O'Clock)}

Old favorites, with sweet-scented flowers of many different colors. They open in the afternoon and wither in the morning. Mixed, 5 cts. per pkt. 


\section{MIMULUS (Monkey Flower)}

Flowers showy and oddly marked; ground color white or yellow, flaked and spotted with maroon, scarlet or crimson. Plants dwarf and compact, and bloom continuously.

M. moschatus. The well-known Musk Plant, with strongly-scented yellow flowers. Io cts. per pkt.

M. tigrinis grandiflorus. Large-flowering new tigered and spotted varieties in many rich colors. Io cts. per pkt.

\section{MESEMBRYANTHEMUM CRYSTALLINUM} (Ice Plant)

Glistening waxen leaves and stems, covered with a shining granular coat. Flowers quite pretty, and of various colors; plant trailing, about 6 inches high; well adapted for baskets, vases, borders, etc. Mixed, 5 cts. per pkt.

\section{DWARF NASTURTIUMS}

Tom Thumb Varieties, for Bedding

None of the old-fashioned plants deserve their renewal of popularity better than the Nasturtium, so brilliant and varied in coloring, free in bloom, and picturesque in appearance. Its brave and hardy habit of growth, even in hottest suns and poor soils, once gave it the name of "the soldier's flower," which was well borne out by the rollicking air of the climbing varieties; but now the artists claim it, and its pale green, shield-shaped leaves and vivid flowers appear on all sorts of choice bric-a-brac, be sides being prime favorites for cut-flower work and personal adornment. The Dwarf Nasturtiums form thick masses of leaves and flowers not more than a foot in height.

Beauty. Very bright; flowers yellow and scarlet, of the most showy description. 5 cts. per pkt., $25 \mathrm{cts}$. per oz.

Empress of India. A splendid dark-leaved sort, with brilliant crimson flowers. 5 cts. per pkt., 25 cts. per oz.

Colden King. Large flowers of deep golden yellow. 5 cts. per pkt., 25 cts. per $0 z$.

King Theodore. Dark, rich maroon, the petals looking as though cut from velvet. 5 cts. per pkt., $25 \mathrm{cts}$. per oz.

Aurora. Very beautiful flowers, varying in color from primrose to pale pink, and lower petals tinged with carmine. 5 cts. per pkt., 25 cts. per oz.

cloth of Cold. Golden yellow foliage; light scarlet flowers; very effective. 5 cts. per pkt., 25 cts. per oz.

Prince Henry. Leaves cream-colored, mar bled and spotted; bright crimson-scarlet flowers. 5 cts. per pkt., 25 cts. per oz.

Scarlet. Bright scarlet. $5 \mathrm{cts}$. per pkt. $25 \mathrm{cts}$. per $\mathrm{Oz}$.

Crystal Palace Cem. Sulphur, spotted maroon. 5 cts. per pkt., 25 cts. per $\mathrm{Oz}$

Ruby King. Bright, ruby red. 5 cts. per pkt., $25 \mathrm{cts}$. per oz.

Superb Mixture of above-named varieties. $5 \mathrm{c}$. per pkt., $25 \mathrm{c}$. per oz.

FINE MIXTURE of all sorts. Will produce fine flowers of many colors. 5 cts. per pkt., io cts. per oz.

For Climbing Nasturtiums, see Ornamental Climbers.

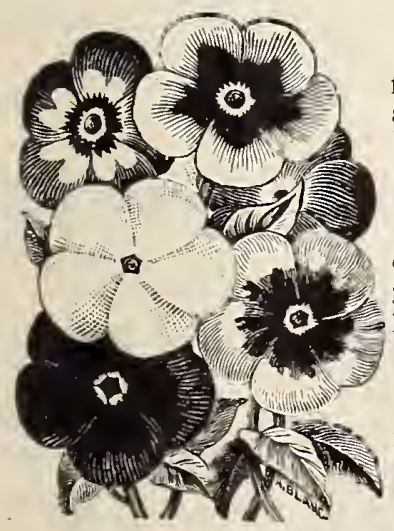

Phlox Drummondii.

\section{NOLANA}

Beautiful trailing border plants, with flowers in all shades of blue and yellow and white; also admirable for hanging baskets, etc. Mixed, 5 cts. per pkt.

\section{NIGELLA（Love=in=a=Mist)}

A delicately pretty plant; light blue or white flowers, set in a mist of feathery pods. Mixed, 5 cts. per pkt.

\section{NEMOPHILA}

Of compact habit; oddly and beautifully colored flowers of blue, purple and white, in unusual markings and blendings. Mixed, 5 cts. per pkt.

\section{OENOTHERA}

Evening Primrose)

Flowers large, fragrant and showy, white and yellow being the predominating colors, affording a fine display. Mixed, $5 \mathrm{c}$. per pkt.

\section{POPPIES}

The annual poppies are quite as brilliant and effective for al purposes as the old-fashioned perennial sorts. They grow freely in any good soil.

\section{SINGLE POPPIES}

Tulip Poppy. Grows I2 to I4 inches tall, branches freely, and bears brilliant crowns of from 50 to 60 large, vivid scarlet flowers. Begin to bloom in early June and continue until late. 5 cts. per pkt.

Shirley. Semi-double, with daintily marked and colored flowers of light gauzy appearance. Mixed, 5 c. per pkt Single Mixed. All the best sorts and colors. 5 cts. per pkt.

\section{DOUBLE POPPIES}

Mikado. Each blossom is a large, soft ball of finely divided petals, pure white at the base, flaming into brilliant crimson-scarlet toward the tips.

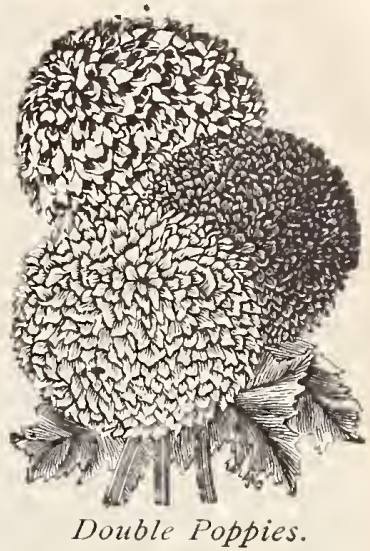

Double Poppies.

Peony-Flowered Double. Large, very double and shapely, brilliantly colored, free-blooming, and more lasting than is usual

\section{with Poppies. Mixed, $5 \mathrm{cts}$. per pkt}

White Swan. Very handsome, snowy flowers; graceful, of fine size, fringed and double. 5 cts. per pkt.

For other varieties of Poppies, see Perennials.

\section{PETUNIAS}

No annual of the garden is more lavish with its flowers, or more readily adaptable to any and every purpose, than the Petunia. So popular has it become that enthusiast have given years of patient care to its improvement, and we now have superb show varieties, fringed, ruffled and double, mottled, striped and self-colored.

\section{LAR GE = FLOWERING DOUBLE} FRINGED PETUNIAS

Will produce strong branching plants, prodigal of handsome flowers, very doubl and waxen, in all the best colors; the lighter tinted ones are especially beautiful. 50 cts. per pkt.

LARGE - FLOWERING SINGLE FRINGED PETUNIAS

Large-Flowering Single Choicest Mixed

A choice mixtuie from superb strans

combining extreme elegance of form with

great diversity of bright and delicate colors. 25 cts. per pkt.

InImitable Striped and Blotched. Finely shaped flowers, with stelliform blotches. All sorts. Io cts. per pkt.

Good Mixed. We will give an equal percentage of all choice types. 5 cts. per pkt.

\section{PHLOX DRUMMONDII}

The Drummond Phloxes have every quality desirable in a fine bedding plant. With brilliancy and variety in color they combine grace and refinement of form, a free and constant blooming habit, neat, compact growth and ease of culture.

Phlox Drummondii nana compacta. These charming and unique Divarf Phloxes are of neat, compact habit, growing only about 8 inches high. Choice mixed colors. $5 \mathrm{cts}$. per pkt.

P. - fimbriata. Large clusters of flowers with fringed petals; light and effective. Mixed colors. $5 \mathrm{cts}$. per pkt

P. - cuspidata. The new Star Phloxes. Pretty star-shaped flowers, forming a lace-like cluster. 5 cts. per pkt.

\section{PHLOX DRUMMONDII, LARGE=FLOWERING} Flowers as Large as in the Perennial Class

Phlox Drummondll grandlflora alba. Pure white. $5 \mathrm{cts}$, per plat.

P. - - striata. Richly striped with red and rose. 5 cts. per pkt.

P. - - Isabellina. Flowers yellow; distinct a:nd new. $5 \mathrm{c}$ per $\mathrm{p}$

P. - - kermesinasplendens. Vivid crimson, white eye 5c. perpkt.

P. - - Mixed Varieties. All varieties mixed. $5 \mathrm{cts}$. per pkt 


\section{Pansies}

We wish to call especial attention to our large and fine assortment of Pansy seed, which includes all famous and distinct largeflowering strains, and in separate colors all the most desirable shades and blendings. The collection is quite complete, and contains only he finest and purest strains.

A garden without Pansies is an anomaly now-a-days, for their bewitching flower-faces are grown and loved everywhere. The plants will live on from year to year, like other species of Violets, but the flowers become smaller as the parent stem grows older, and so for a continual supply of flowers, the seeds are sown twice a year -in spring and autumn.

Fine Mixture. A good strain of fine colors. $5 \mathrm{cts}$. per pkt.

Finest German Mixed. From a splendid strain of large-flowering and finely blotched varieties. Io cts. per pkt.

Large-Flowering Prize. Finest mixed. Special mixture prepared by ourselves, which embraces the most striking and beautiful colors. Io cts. per pkt.

English Show. From a celebrated English grower; choice strain. I5 cts. per pkt.

Bugnot's Superb Blotched. Very beautiful; extra large-flowering variety. I 5 cts. per pkt.

Odier. A distinctly blotched variety of great beauty. I5c. per pkt. Trlmardeau, or Giant Pansies. Beautiful class of vigorous grotth, and flowers of enormous size; finest strain. Io cts. per pkt.

Cassier's. A splendid strain; beautifully marked, large flowers. I5 cts. per pkt.

Giant White. With purple eve; very beautiful. Ioc. per pkt.

Clant Yellow. Black center. Io cts. per pkt.

See that your garden has a fine bed of Pansies.

\section{PORTULACA}

Sturdy little trailing plants, that bloom brightest during our warmest, driest weather. Beds of them form brilliant rainbows of color on sunshiny mornings ; the sun cannot be too warm for them.

SIngle Mixed. In many rich colors. 5 cts. per pkt.

Doubie Mixed. A large percentage of the flowers will be as double as little roses. Io cts. per pkt.

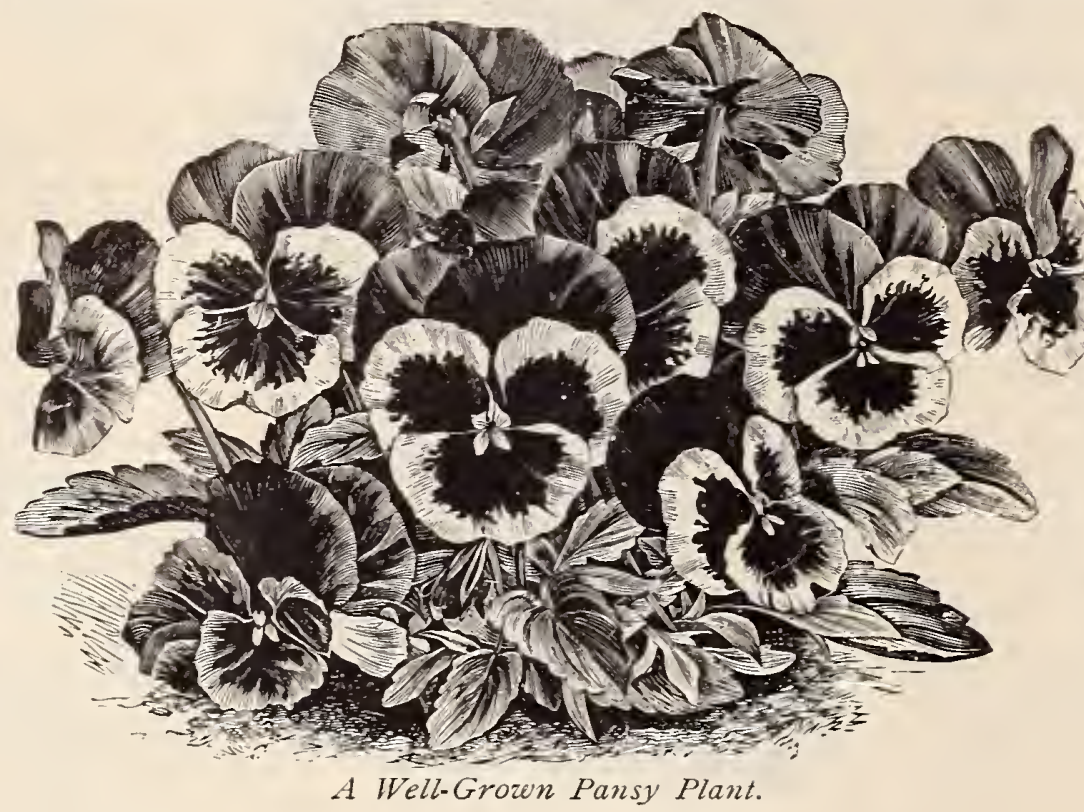
per pkt. I5 cts. per pkt. Curious and pretty; an old
popular. Mixed, 5 cts. per pkt.

\section{VIRGINIAN STOCKS (Malcolmia)}

Pretty, profuse-flowering little plants, about 3 inches tall, with clusters of red and white flowers. 5 cts. per pkt.

\section{SALPIGLOSSIS GRANDIFLORA}

This elegant half-hardy annual flowers in late summer and autumn. The blossoms are velvety, with deep veins and markings, lily-shaped, and quaintly lovely. IIixed, 5 cts. per pkt.

\section{SALVIA (Flowering Sage)}

Magnificent bedding plants, all ablaze with long spikes of blue or scarlet flowers from June until October. I to 2 feet tall.

s. splendens. Flowers bright scarlet; a general favorite. Io cts.

S. patens. Leaves silvery; flowers large, and beautiful sky-blue.

\section{SAPONARIA CALABRICA (Bouncing Bet)}

A hardy annual, growing into thick clumps, and producing masses of fragrant red, cruciform flowers. 5 cts. per pkt.

\section{SCABIOSA GRANDIFLORA (Mourning Bride)}

Curious and pretty; an old-fashioned flower, still deservedly

\section{VERBENAS}

Seedling Verbenas are more robust in growth and produce larger and finer flowers than those grown from cuttings, and the light-colored varieties frequently have fragrant flowers when grown from seed. This is one of our brightest and best bedding plants, and its fine trusses of flowers represent every shade of every color except yellow. Plants from seed sown early in spring keep their beds gay with flowers from midsummer until frost they are trailing in habit, and wide-spreading, loving a rich, sandy soil, plenty of room and full sunshine. No finer seed than ours can be procured anywhere.

Verbenas, MAMMOTH VARIETIES. This superb strain is a great improvement on the older varieties, both in size and color of flowers and habit of plants.

\section{STOCKS}

For an Early and Profuse Display of Brilliant Flowers

Fragrant and free-blooming, and easy to grow, either in beds or pots. Almost all the varieties have long, handsome spikes of flowers, which are admirable for cutting, and remain fresh a long while. The Ten-Weeks Stocks are especially popular, because they bloom so soon after the seed is sown.

Dwarf Queen. Dark blood-red; same habit as Snowflake. Io cts. per pkt.

Snowflake. Very early flowering, and indispensable for forcing. Vigorous dwarfs of the Wallflower-leaved section; produce long spikes of large, double, snow-white flowers. Io cts. per pkt.

\section{LAR GE=FLOWERING TEN=WEEKS STOCKS}

The plants flower Io to I2 weeks after the seed is sown. We offer a marificent strain of this in separate colors: Pure White, Flesh colored, Chamols-Buff, Carmine, Dark Crimson, Dark BloodRed, Light Blue, Chestnut-Brown, Pink, Scarlet, Dark Blue. Io cts, each; Mlxed, Io cts. per pkt.

CUT-AND-COME-AGAIN Stocks. An unusually free-blooming species. The plants grow about 2 feet high, and send out numerous side branches, each of which bears a cluster of pure white, fragrant flowers, beautifully shaped and very double. From spring until late in fall the plants are covered with flowers, and they thrive equally well in pots or beds. Io cts. per pkt. The florets average an inch in diameter, and have clearly defined margins and large white centers. The trusses are large in proportion, and borne in great profusion upon robust, vigorous plants. Seed from finest flowers. White, Scarlet, Pink and Mixed, each Io cts. per pkt.

v. nana compacta (New Dwarf Varieties). Of very dwarf and spreading habit, requiring no pegging down. Mixed seed, Io cts. per pkt.

V. Choice Mixed. Seed saved from finest flowers. 5 cts. per pkt.

\section{VISCARIA}

Abundant bloomers. Plants about a foot in height ; flowers all tints and shades of red, from scarlet to pale rose and pure white. 5 cts. per pkt.

\section{ZINNIA ELEGANS (Youth and Old Age}

All of them, but especially the dwarf sorts, give gay effects in bedding. The taller sorts are very useful for inixed borders or massing in large clumps.

Zinnia grandiflora plenlssima (The new Giant Zinnia). Very large and double flowers of handsome form, in all the rich Zinnia colors; plants strong, erect and branching. 5 cts. per pkt.

z. parvlflora (The Lilliput-Flowered Zinnias). Tiny flowers of double, perfect form; unique and charming for bouquets. All colors. 5 cts. per pkt.

z. elegans, Double Mixed. Many kinds and colors. 5c. per pkt. z. - Curled and Crested. Finely varied flowers. $5 \mathrm{cts}$. per pkt. 


\section{Seeds of Hardy Perennials}

MANY PERENNIALS BLOOM THE FIRST SEASON IF SOWN EARLY

The permanent character of the Hardy Perennials, which live and bloom from year to year for an indefinite period, with but little care, renders them very popular among all classes of gardeners. Some of our very finest flowers are to be found among these plants for the hardy garden, many of which, though old-fashioned, are dear through associations.

\section{ACONITUM NAPELLUS GRANDIFLORUM}

(Monkshood)

Curious, helmet-shaped flowers, quite pretty and striking, produced on tall racemes above the finely cut foliage. Very prodigal of its unusually large, bright blue flowers, which last from midsummer until late in autumn. Io cts. per pkt.

\section{ADONIS VERNALIS}

A bright, early spring plant, with large, showy flowers of sunshiny yellow. 5 cts. per pkt.

\section{ALYSSUM SAXATILE COMPACTUM}

Low-growing, with light green, silky foliage and golden yellow flowers. Very useful for shaded places. 5 cts. per pkt.

\section{ANEMONE}

Old favorites, and among our earliest spring flowers. Various shades of scarlet, purple, blue and white, sometimes striped.

Fine Mixed. $5 \mathrm{cts}$. per pkt.

\section{ANTIRRHINUM (Snapdragon)}

Bloom the first year if sown early, and make very bright and showy bedding plants. Varieties with dark flowers are rich and relvety in depth of color. The dwarf sorts grow only 6 or 8 inches tall; other species about a foot high.

Tall Mixed. Seed from fine flowers of best colors. $5 \mathrm{cts}$. per pkt. Tom Thumb, Mixed. All colors; fine for bedding. $5 \mathrm{cts}$. per pkt.

\section{AQUILEGIA (Columbine)}

Very handsome and free-blooming. Bear curiously sliaped flowers in many bright and delicate colors. Grow about 2 feet tall, and display their flowers well against a mass of light and pretty foliage. Aquilegia chrysantha. Gold-spurred. New, and much admired flowers large, and bright golden yellow. Io cts. per pkt.

A. grandiflora alba. Large, snow-white flowers, with long spurs. ro cts. per pkt.

A. vulgaris fl. pl. Double varieties mixed. These will give an abundance of odd and very pretty flowers. 5 cts. per pkt.

\section{AURICULAS, or HARDY PRIMULAS}

Cowslips, or Hardy Primroses, are favorite early spring flowers, with clusters of bright blossoms in different shades of red and yellow. The clumps increase rapidly.

Primula auricula. Nixed seed of best varieties. Io cts. per pkt. P. vulgaris. The true, fragrant yellow Primrose. Io cts. per pkt.

\section{CAMPANULA (Bellflower)}

Very popular for mixed beds and borders. They bear a profusion of large, bell-shaped flowers in blue, rose, pink and white.

Campanula pyramidalis. Flowers in many shades of blue. Hixed, 5 cts. per pkt.

C. Meadia calycanthema (Cup-and-Saucer). Handsome flowers in many tints of blue, rose and white. Mlixed, $5 \mathrm{cts}$. per pkt.

c. - (Canterbury Bell). Produces large, nodding, bell-shaped flowers of charming form and many beautiful shades ; single and double. Each, 5 cts. per pkt.

\section{DELPHINIUM}

Indispensable to the hardy garden, because of their long and graceful spikes of bright blue flowers.

Delphinium formosum. Rich blue flowers, with white centers. Splendid mixture, 5 cts. per pkt.

\section{DIANTHUS, or PINKS}

Dianthus Barbatus (Sweet IVilliam). Attractive, profuse-blooming garden plants. The flowers have a quaint perfume.

D. - Single Mixed. All the best colors, 5 cts. per pkt.

D. - Double Mixed. Seed from fine double flowers of many colors. Io cts. per pkt.

D. Gardnerianus (Double Hardy Garden, or Grass Pink). This species is in perfection about the first of June. The plant is hardier than the carnation. $5 \mathrm{cts}$. per pkt.

D. plumarius (Double Pheasant's Eye Pink). Double fringed flowers, fragrant, of white, crimson or purple. Io cts. per pkt.

\section{BELLIS PERENNIS}

(Double English Daisy

This dainty little flower is a farorite everywhere. It is of easy culture, and grows well in all soils, if given a rather moist, shaded situation. Flowering plants grow readily from seed sown in the border in early spring, or in boxes in the house. They seldom exceed 6 inches in height, and bloom from spring until midsummer; in some localities sparingly in autumn. An exquisite plant for shady borders and edgings to beds, or for window-boxes in a cool room where in win ter fiowers are sent up thickly, forming rainbows of pink and white.

Bellis perennis $\mathrm{fl}$ pl. Flowers double. Mixed colors, ro cts. per pkt.

B. - Longfellow. The bright rose-colored

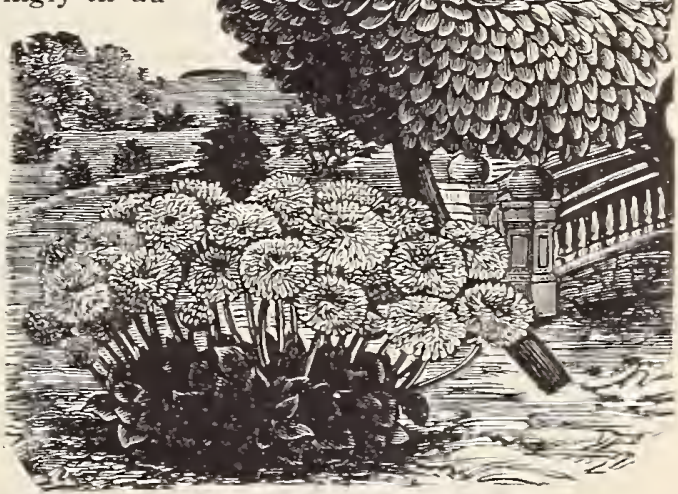

Snowball Dais
B. - Snowball. A pure white variety of the Daisy, with flowers very large and perfect, and long stems. Io cts. per pkt.

\section{DIGITALIS, or FOXGLOVE}

A stately, handsome plant, from 3 to 4 feet high. Its fine waxen flowers droop gracefully from long spikes, upon which they are set thickly. Among shrubbery, or as a background for lower plants, it gives great satisfaction. Nixed, $5 \mathrm{cts}$. per pkt.

\section{GAILLARDIA GRANDIFLORA}

Splendid new perennial variety, with very large, handsome flowers, having dark crimson centers marked with rings of many brilliant colors. Io cts, per pkt.

\section{GYNERIUM ARGENTEUM (Pampas Grass)}

The silvery plumes are very light and graceful in effect, and are much used for all sorts of indoor decoration. For clumps upon lawns the plant is elegant and striking, and usually grows from 6 to 8 feet high. Requires winter protection. 5 cts. per pkt.

\section{GYPSOPHILA PANICULATA (Baby's Breath)}

A dainty, mist-like plant, with sprays of small, white, star-shaped flowers and delicate foliage, $5 \mathrm{cts}$. per pkt.

\section{HOLLYHOCKS}

Chater's Superb Strain; Fine Colors in Separate PKts.

Stately and handsome old-fashioned plant. Ot late years it has been greatly improved, and its tall spikes of double silken flowers are magnificent when grown either in clumps or lines. Chater's Hollyhocks are famous everywhere as the finest strain grown. Separate Colors. Pure White, Scarlet, Golden Yellow, Peach, Pink, Io cts. per pkt. The 5 varieties for $40 \mathrm{cts}$.

LAVANDULA VERA (Lavender)

Grown for its fragrant leaves and flowers, which retain their fragrance when cut and dried. 5 cts. per pkt.

LOBELIA CARDINALIS (Cardinal Flower)

Long spikes of intense scarlet flowers; one of the most brilliant plants in cultivation. Suitable for all situations. Io cts. per pkt.

PERENNIAL PHLOX (P. decussata)

Fine clumps of these plants form magnificent lawn and garden rnaments, and nearly all bright colors are represented in the large and handsome flower-beds. Dwarf and tall, each Io cts. per pkt. For Drummond Phloxes, see Aanuals. 


\section{MYOSOTIS (Forget $=\mathrm{Me}=\mathrm{Not}$}

Thrive best in moist, shaded places, forming neat, compact little plarts, bright with graceful sprays of starry blue flowers, which

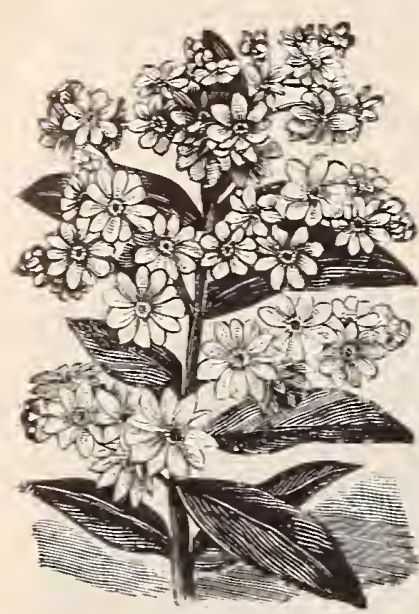

Myosotis. form one of the chief attractions of the garden in early spring. For pot culture, too, ther are very pretty, if given cool treatment, and frequently bloom the first season.

Myosotis palustris (the true Forget-Me-Not). Flowers bright blue, with a large golden yellow eye. Io cts. per pkt.

M. alpestris Victoria. A new dwarf variety, which forms shapely, rounded plants, and is well adapted to pot culture, although it loves the hardy green quite as well. Its sky-blue flowers are borne in thick clusters, the center ones being double. Ioc. per pkt.

M. rosea. A new rose-colored varietyof the Victoria. Io cts. per pkt.

\section{PENTSTEMON} (Beard Tongue)

The flowers are borne in graceful spikes. The plants are herbaceous, and bloom from early summer until frost. The flowers are white, b!ue, scarlet, crimson, yellow, etc. Nixed, Io cts. per pkt.

\section{SWEET WILLIAM}

See Dianthus barbatus.

\section{PAPAVER ORIENTALE}

Large, brilliant flowers, rich and bright in their color. The loose, silken petals have each one a blotch of black at the base. The plants are about 2 feet high, and entirely hardy. Io cts. per pkt.

\section{SILENE (Catchfly)}

Appear in early spring, and last until the late autumn; vary in height, color of flowers, etc., but all free-blooming; well adapted to exposed borders, etc. Mixed, 5 cts. per pkt.

\section{VIOLA ODORATA}

\section{Sweet=Scented Violet}

IVell-known, delightfully fragrant little flowers, which bloon most freely in early spring and fall. The seed should be sown early. Ilixed, Io cts. per plt.

\section{WALLFLOWERS}

Chionanthus)

Their exquisite perfume and their rich, quaint, bright colors, usually brownish red, yellow and violet, should give them a place in every garden. Then grown in the open ground the plants should be potted in autumn. Will bloom in winter if kept cool.

Double Mixed. This variety gives fine flowers in all the Wallflower colors. Io cts. per pkt.

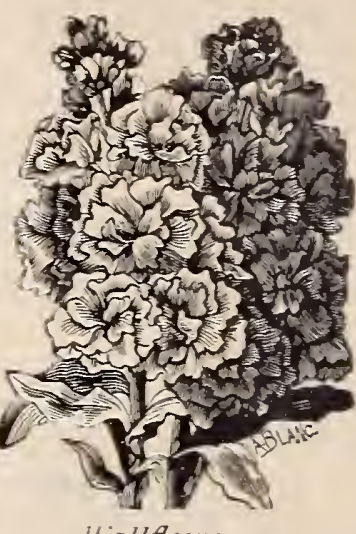

Single Mixed. This seed is chosen from select plants of best colors. 5 cts. per pkt.

\section{Seeds of Ornamental Foliage Plants}

\section{FOR SUMMER BEDDING, BORDERS AND POT CULTURE}

We include in this department all the best ornamental foliage plants largely used in outdoor bedding. More tender sorts, useful chiefly for house and conservatory decoration, will be found under Seeds of Greenhouse Plants.

\section{ACANTHUS LATIFOLIUS}

A tall, herbaceous plant of beautiful and stately habit, grown, like the ricinus, for its rich tropical leafage. Handsome and effective, whether grown as a center for foliage beds or as a specimen plant for lawns and borders. Io cts. per pkt.

\section{AMARANTHUS}

Tall-growing plants, with showy leaves, variegated with many shades of red, yellow and green, and long racemes of curious flowers. Amaranthus caudatus (Love-Lies-Bleeding). Three feet tall; blood-red. 5 cts. per pkt.

A. cruentus. The well-known Prince's Feather. 5 cts. per pkt.

A. Henderi. Of beautiful habit; brown, dark red and bronze. 5 cts. per pkt.

A. nobilis pyramidalis. 5 cts. per pkt.

A. tricolor (Joseph's Coat). Leaves a beautiful mosaic of color. 5 cts. per pkt.

\section{BEET}

Ornamental-Foliaged, Best. In various culors. $5 \mathrm{cts}$. per pkt.

\section{CENTAUREA (Dusty Miller)}

Silver-leaved and indispensable for ribbon beds and borders, their soft, natural tints of grayish green being very effectual in toning down and harmonizing contrasts in more brilliant leaves. Centaurea candidissima. Leaves broader and whiter than in any other silver-leaved sort. Io cts. per pkt.

c. gymnocarpa. Of very graceful growth; a fine variety. Io cts. per pkt.

\section{COLEUS}

The leaves are of many shapes and bright colors, and nearly all varieties have a rich, velvety appearance. Seed sown in March or April will produce fine plants for bedding. I5 cts. per pkt.

\section{CINERARIA MARITIMA CANDIDISSIMA}

Another fine silver-leaved plant, used in ribbon-bedding, vases, etc. Leaves are silvery white; flowers yellow. $5 \mathrm{cts}$. per pkt.

\section{EUPHORBIA (Painted Leaf)}

Euphorbia heterophylla. Glossy green leares, forming large bracts on the ends of the branches, changing in midsummer to brilliant scarlet. Io cts. per pkt.

E. variegata (Snow-on-the-Mountain). Of robust growth, with fine green leaves, striped with white. 5 cts. per pkt.

\section{PERILLA NANKINENSIS}

A beautiful plant ; leaves rich, dark purple; fringed. Contrasts with silver-leaved foliage plants. A half-hardy annual. $5 \mathrm{c}$. per pkt.

PYKETHRUM AUREUM (Golden Feather)

Golden yellow foliage, finely cut, producing rich, soft effects in bedding; hardy annual. $5 \mathrm{cts}$. per pkt.

\section{RICINUS}

Castor $=$ Oil Bean)

Plants of stately growth, with fine fruits and leaves.

Ricinus Borboniensis arboreus. Growth I5 feet; leaves enormous. 5 cts. per pkt.

R. Cambodgensis. Redblack stems; very dark leaves; very distinct. 5 cts. per pkt.

R. Glbsoni (Duchess Edinburgh). Dark purple leaves and stems. 5 cts. per pkt.

R. Zanzlbariensis. Anentirely new and distinct class. The plants attain great dimensions, presenting a splendid aspect with their gigantic leaves. Seeds also very: distinct, very large and of exquisite tints. Mixed, $5 \mathrm{cts}$. per pkt.

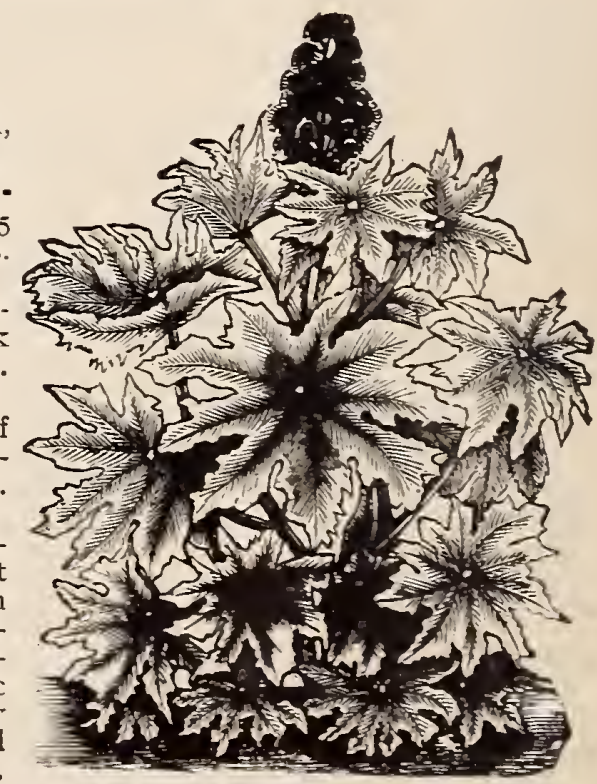

Ricinus. 


\section{Ornamental Climbers}

Vines are the tapestry of the garden, embroidered with their own blossoms. All the most popular hardy annual and perennia kinds will be found here; tender sorts, among seeds of Greenhouse Plants.

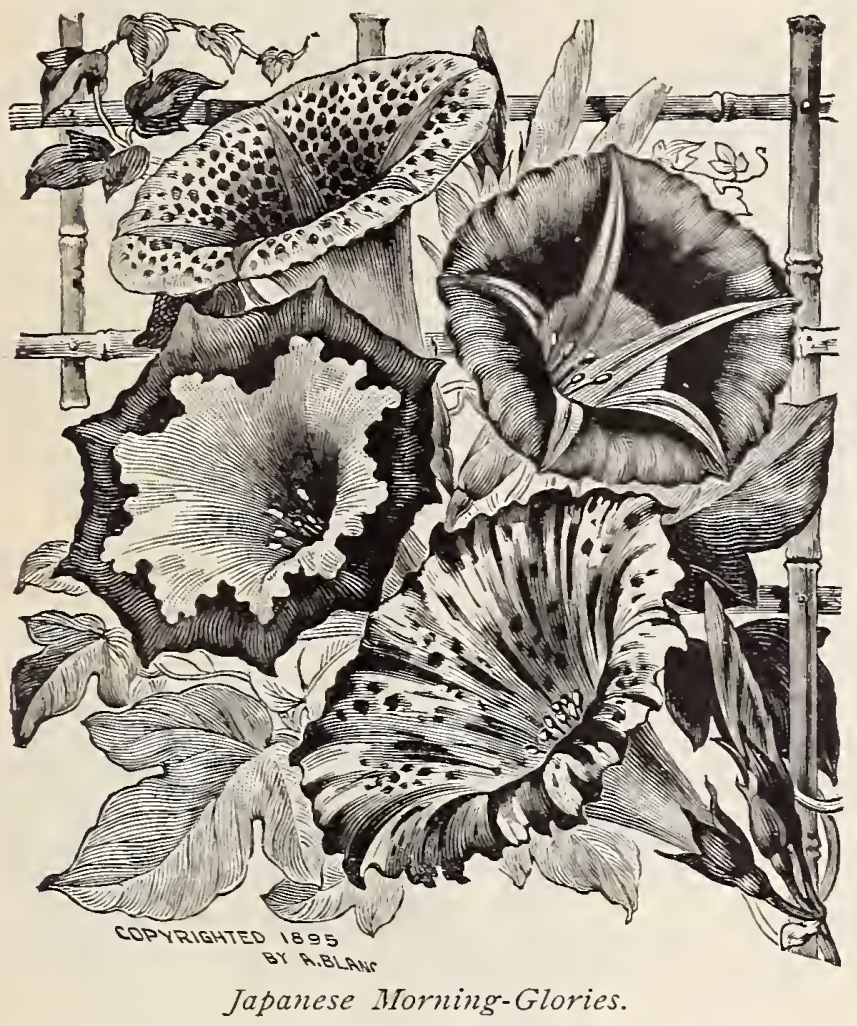

AMPELOPSIS VEITCHII (Japan, or Boston Ivy)

A beautiful vine for covering walls and buildings, to which it adheres closely: The leaves color beautifully in autumn. Ioc. per pkt.

\section{CENTROSEMA GRANDIFLORA}

Large, pea-shaped flowers, produced in clusters : in color rosy violet, with broad, feathered markings of white. Foliage abundant and graceful. A hardy perennial, climbing 6 to 8 feet in a season, and blooming abundantly. Io cts, per pkt.

\section{COBAEA SCANDENS}

A tender annual of very rapid and luxuriant climbing habit. The deep violet-blue flowers are large and bell-shaped, averaging 2 inches in length and $1 / 2$ inches across. ro cts. per pkt.

\section{DOLICHOS LABLAB (Hyacinth Bean}

Noted for its large clusters of snowy white or purple flowers. It grows rapidly, and makes a fine screen of thick foliage. A tender perennial. 5 cts. per pkt.

\section{HUMULUS JAPONICUS (Japanese Hop)}

Annual climbers of very rapid growth, with dense foliage. The leaves remain bright and fresh and rich looking until late in the fall.

Humulus Japonicus. Leares plain green, something like those of the common hop. Seed sown in early spring produces plants which will cover a wide spread in a short time, $5 \mathrm{cts}$. per pkt.

H. - variegatus. Leaves broadly edged with cream color, and marked and shaded with silvery white and deep green; often a whole branch and its leaves will be pure white. At a little distance the plant looks as if it were covered thickly with white blossoms. It is very vigorous and hardy. Io cts. per pkt.

LATHYRUS LATIFOLIUS (Everlasting Pea)

Hardy perennial climber, growing 6 to 8 feet high when trained on a trellis. Flowers borne in large clusters. Red and white, mixed, Io cts. per pkt.

\section{MAURANDYA}

Graceful annual climber for window or conservatory ; admirable to hang from vases, and to cover stumps and low trellises; blooms very freely. Io cts. per pkt.

\section{Grand "Imperial Japanese"}

\section{MORNING=GLORIES}

These grand climbers have given unbounded satisfaction and surprise at their great beauty and variety. The vines are of strong and robust growth, attaining a height of from 30 to 50 feet. The foliage is most luxuriant, distinct and varied-some vines have rich, vivid green leaves, others have silvery leaves, some with yellow leaves, and many produce leaves mottled and checkered like rich mosaics of light and dark green, white and gray. The intermingling vines and brightly contrasting colored leaves are wonderfully pretty and effective, even when the flowers are not open. But their surpassing charm lies in the entrancing beauty and gigantic size of the flowers; they measure from 4 to 6 inches across, and their greater substance causes them to remain open much longer than ordinary Morning-Glories. The colors of the flowers, shadings and markings are limitless, and are really wonders of nature, of such incomparable beauty that descriptions are inadequate. Some flowers are of deep, rich, velvety tones, others daintily tinted and shaded. The solid colors range through reds from soft rose to crimson, bronze and garnet-maroon from daintiest light blue to ultramarine, indigo and blackish purple from snow-white to cream and silver gray. Some are striped, starred and spotted, others have magnificent edges and throats. They are of the easiest culture. Sow early in a warm, sunny position in good rich soil, and give plenty of water in dry weather. Mixed colors, Io cts. per pkt.

\section{CONVOLVULUS MAJOR (Morning=Glory)}

A well-known and farorite annual, rapid in growth and prodigal

Splendid Mixture. Will produce flowers of all the best colors.

5 cts. per pkt.

\section{IPOMOEA}

In the large class of tender annuals are included many handsome climbers. Evening- as well as Mlorning-Glories, and other favorite rines almost as popular and beautiful.

Ipomœa setosa (Brazilian Morning-Glory), Beautiful rose-colored flowers and huge leaves; remarkably luxuriant in growth. Io cts. per pkt.

I. Leari. Flowers violet-blue; an elegant greenhouse species. lo cts. per pkt.

I. quamoclit (Cypress Vine). Delicately cut foliage and small star-shaped flowers of scarlet or white. Mixed, $5 \mathrm{cts}$. per pkt.

I. grandiflora (Moonflower). The large pure white flowers of this plant open at night; produced in great abundance, and quite ragrant. Io cts. per pkt.

I. Heavenly Blue. Foliage very large and heart-shaped; flowers 4 to 5 inches across, borne in large clusters; light blue, with yellow throats. The bloom also hides the foliage. Ioc. per pht.

I. Bona Nox (Good-Night, or Evening-Glory). Most beautiful large violet flowers. $5 \mathrm{cts}$. per pkt.

\section{NASTURTIUMS (TROPAEOLUMS) \\ (For Dwarf Varieties, see page 25}

The gay and picturesque Nasturtiums are almost as popular among climbers as sweet peas. Their rapid and luxuriant growth quickly corers trellises, verandas, fences, or any unsightly object, with a beautiful mass of oddly pretty leaves and brilliant flowers. No plant could be freer with its blossoms, or display them in a more graceful way.

Tropæolum majus atropurpureum. Crimson. 5 cts, per pkt., $20 \mathrm{cts}$. per oz.

T. - Edward Otto. Brownish lilac. $5 \mathrm{cts}$, per pkt., $20 \mathrm{cts}$. per oz

T. - hemisphericus. Orange. 5 cts. per pkt., $20 \mathrm{cts}$. per oz.

T. - Pearl. White. 5 cts. per pkt., 20 cts. per oz.

T. - Rœgelianum. Violet-ruby. 5 cts. per pkt., 20 cts. per oz.

T. - Scheurianum. Pale yellow spotted. 5c. per pkt., 20c. per oz

T. - Schillingii, Spotted. 5 cts. per pkt., 20 cts. per oz.

T. - Von Moltke. Ruby-rose. 5 cts. per pkt., 20 cts. per oz.

T. - Yellow. 5 cts. per pkt., 20 cts. per oz.

T. FInest Mixed. Seed saved from a choice collection of flowers, in many colors; will produce charming results if planted freely in grsund that is not too rich. $5 \mathrm{cts}$. per pkt., ro cts. per oz.

T. - peregrinum (Canary Creeper). Graceful, winged flowers of pure light yellow. 5 cts. per pkt., $20 \mathrm{cts}$. per oz.

T. - Lobblanum. Very superior for trellises, arbors or vases: flowers very brilliant and rich, borne profusely. Mixed colors, 5 cts. per pkt., 25 cts. per oz. 


\section{SWEET PEAS}

Fashion does not always display so much good taste in her choice of a "pet flower" as when giving the Sweet Pea that place. Already they have become so popular that seedsmen must handle their seeds by the toll, and they are grown galore in hedges, sold in great fragrant heaps from the markets, and worn and carried whenever and wherever possible. Every garden must have its hedge of Sweet Peas, and we are ready to supply you with the best of seed.

All the following varieties, pkt. 5 cts., oz. 10 cts.

Admiration. Pink mauve.

Apple Blossom. Light pink shaded and buff.

Countess of Cadogan. Lilac and blue.

Countess of Lathom. Cream pink.

Dainty. White with pink edge.

Dorothy Eckford. White.

Emily Henderson. White.

Extra-Early Blanche Ferry. Rose and white.

Golden Rose. Light primrose, striped light pink.

Hon. Mrs. E. Kenyon. Large primrose.

Janet Scott. Bright pink and buff.

Jeannie Gordon. Rose and primrose.

King Edward Vil. Bright red.

Lady Grisel Hamilton. Lavender.

Lord Roseberry. Magenta rose.

Lottie Eckford. White shaded lilac and blue.

Lovely. Deep pink shaded to light pink.

Miss Willmott. Large, orange-pink.

Mrs. Walter Wright. Rose-purple.

Navy Blue. Indigo-blue and violet.

Othello. Deep maroon.

Prima Donna. Pink.

Prince Edward of York. Scarlet and crimson.

Royal Rose. Crimson-pink shaded light pink.

Steila Morse. Buff, tinted pink.

Misture of all the above varieties, $0 \mathrm{z} .10 \mathrm{cts}, 1 / \mathrm{lb} .25 \mathrm{cts}, 1 \mathrm{lb} .75 \mathrm{cts}$.

Eckford varieties, mixed, $0 \mathrm{z}, 10$ cts., $1 / 4 \mathrm{lb} .20$ cts., lb. 60 cts.

\section{THUNBERGIAS}

These are among the best half-hardy annual climbers. The vine is of slender and graceful but very rapid growth, with elegant foliage and extremely pretty, dark-eyed flowers of white or yellow.

Thunbergla aiata. Flowers buff, with dark center, very bright and pretty. 5 cts. per pkt.

T. - alba. White flowers, black eye ; of excellent effect. $5 \mathrm{cts}$. per pkt.

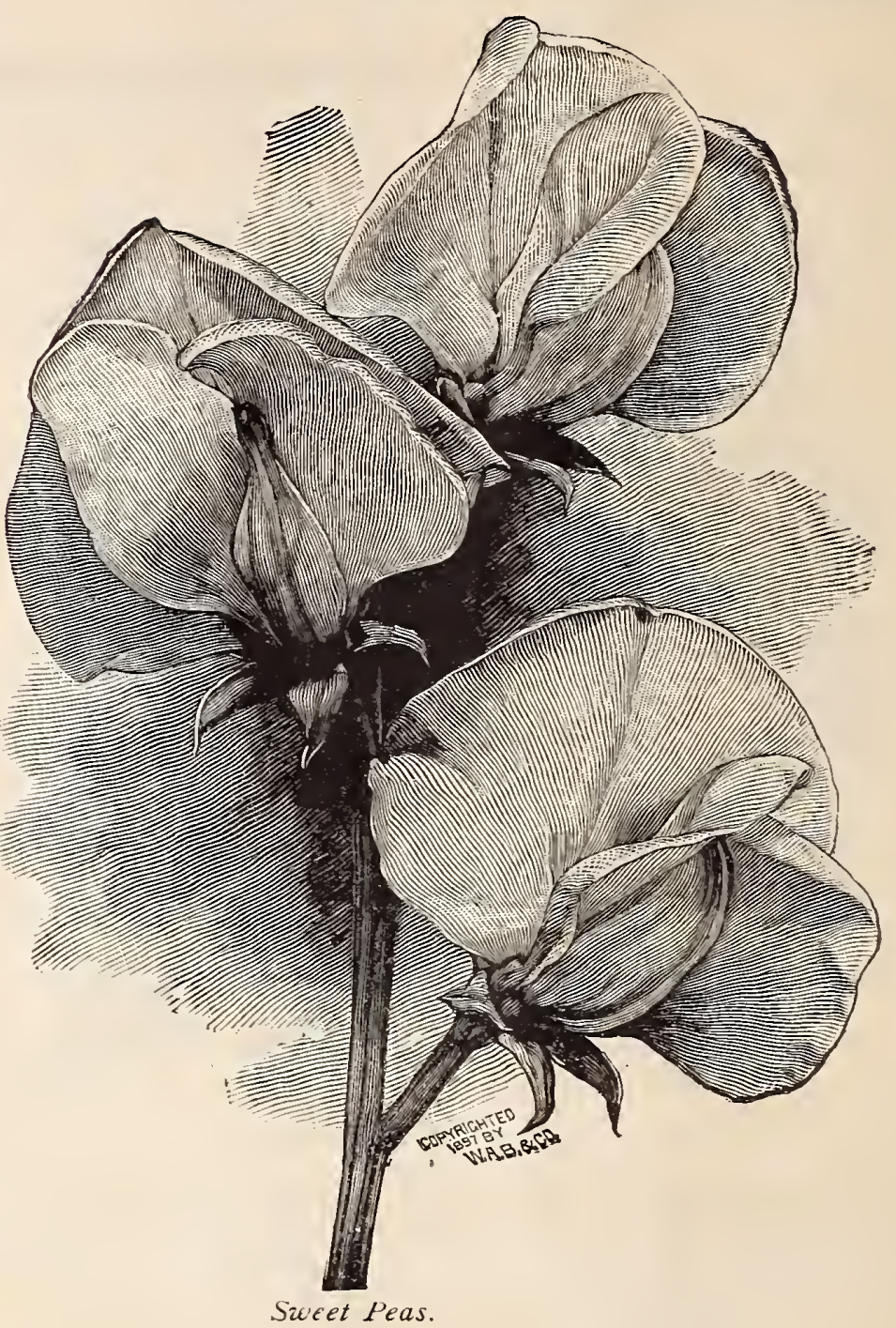

\section{Seeds of Greenhouse Plants}

The rarest and handsomest stove and greenhouse plants may be grown from seed by any amateur who will be careful, first, to procure good seed, then to sow it carefully and tend it well.

\section{BEGONIAS}

Begonias are now grown in such large quantities, both for summer bedding and winter flowers, that many people prefer sowing the seed to buying the plants. We offer species which are especially adapted for bedding, and are also handsome window plants.

Begonia Vernon. A dark-leaved variety; valuable for bedding. The plant is strong, dwarfish and branching in habit, and the coral-red flowers cover it thickly all summer long. Equally valuable for pot culture and winter decoration. $25 \mathrm{cts}$. per pkt.

B. - Tuberous-rooted Mixed, Single. Fresh seed from fine plants will give la'ge flowers of various shapes and colors. The tubers must be lifted and stored in dry sand, in a dry, warm place in autumn $25 \mathrm{cts}$. per pkt.

B. - Mixed Doubie. Seed saved from a fine collection of largeflowering varieties. $25 \mathrm{cts}$. per pkt.

\section{CALCEOLARIAS}

The curiously shaped and oddly marked flowers of these plants at once attract notice.

c. grandiflora. Large-flowering, self-colored varieties; a great diversity of colors. Mixed seed, 25 cts. per pkt.

\section{CHOICE CARNATIONS}

A large proportion of the plants will produce flowers as large, double, fragrant and brilliantly colored as those from purchased plants of named varieties. The Vienna and Grenadin species are excellent for open-air culture, and bloom several weeks earlier than the other sorts.

Early-flowering Vienna. Flowers of all colors. Choice mixed, $25 \mathrm{c}$. per pkt.

Early Grenadin. Bright scarlet flowers, 60 to 70 per cent of them double; very early-flowering. $25 \mathrm{cts}$. per pkt.

Perpetuai, or Tree. Tall plants, continually in flower. Our seed is a choice mixture, and will produce 75 per cent of double fluwers. Io cts. per pkt.

Double Seif-colors. Elegant, fragrant, fringed flowers, of pure and beautiful colors. Io cts. per pkt.

\section{CINERARIA HYBRIDA GRANDIFLORA}

The Cineraria is a very distinct and showy window plant, and it blooms at a season when its magnificent crown of brilliant velvety flowers is most appreciated. Our seed is from a splendid mixture of large-flowering varieties. $25 \mathrm{cts}$. per pkt.

\section{GLOXINIA HYBRIDA}

The waxen flowers of the Gloxinias are large, bell-shaped and richly colored, producing grand effects when different sorts are grouped together. Choice mixed, $25 \mathrm{cts}$. per pkt.

\section{PRIMULAS, or CHINESE PRIMROSES}

Chinese Primroses are noted for their rich and profuse display of flowers in winter, and the length of time to which they prolong it. Growing the plants from seeds is not difficult, and full directions for culture a re given on our seed packets.

Primula fimbriata alba magnifica. Very large, pure white flowers, with yellow eye; delicately fringed. $25 \mathrm{cts}$. per pkt.

P. Sinensis, Fern-ieaved, White. $25 \mathrm{cts}$. per pkt.

P. - Crimson. 25 cts. per pkt.

P. - - Mixed, 25 cts per pkt.

P. - Fine Mixed. Fringed flowers of various colors. 25c. per pkt.

P. Japonica. Beautiful, in shades of crịmson, maroon, lilac, pink and white. ro cts. per pkt. 


\section{Garden Requisites, Etc.}

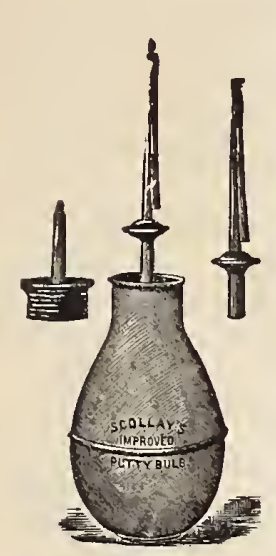

\section{Scollay's Puttying Bulb}

A simple and useful device for ap plying putty to sashes. The putt in a semi-liquid state is ejected by pressing the bulb, enabling one to do the work very rapidly.

\section{Scollay's Insect Powder Puff}

A new device for applying insect powder of any kind to plants, etc. It will be found very useful for house plants and to housekeepers
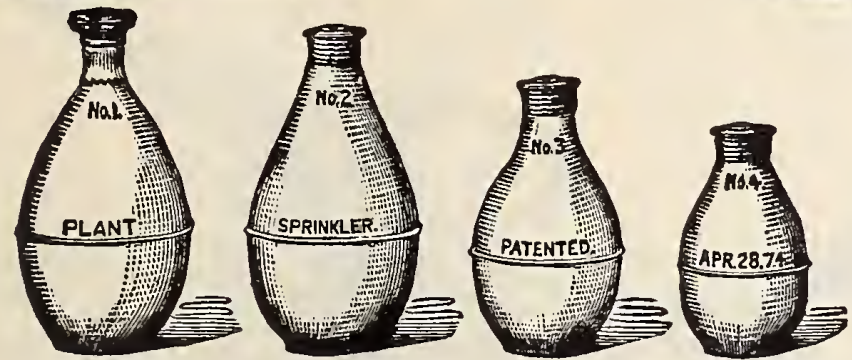

\section{Scollay's Rubber Plant Sprinkler}

Made of rubber with flat bottom and a finely perforated detachable brass top. Very useful in bouquet making and window gardening, for sprinkling and for all purposes where a fine spray is required. Four sizes.

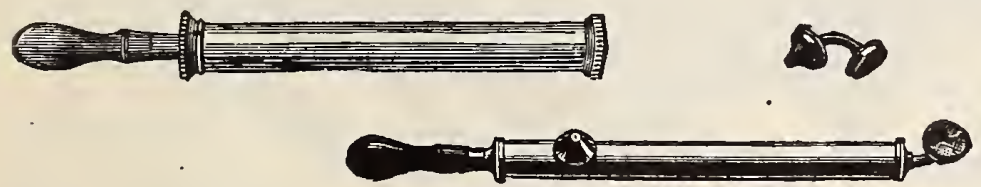

\section{Brass Greenhouse and Garden Syringes}

These Syringes are useful for all horticultural purposes, and are fitted with caps or roses for ejecting water in one stream, for dispersing it in the most gentle manner, or with great force when required. They are especially adapted for whale-oil soap, tobacco juice, etc., in cleaning plants and flowers from those destructive insects which are so injurious to them. Very strongly made of best quality of brass, finely polished, elegant in appearance, not liable to dent or become injured, and if properly cared for will last a lifetime.

\section{Standard Flower Pots} Measurement from inside to inside. Width and Depth

Special prices on large quantities.

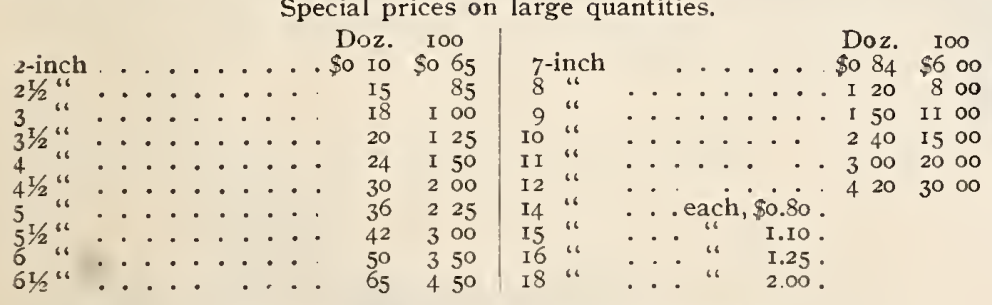

\section{Flower Pot Saucers}

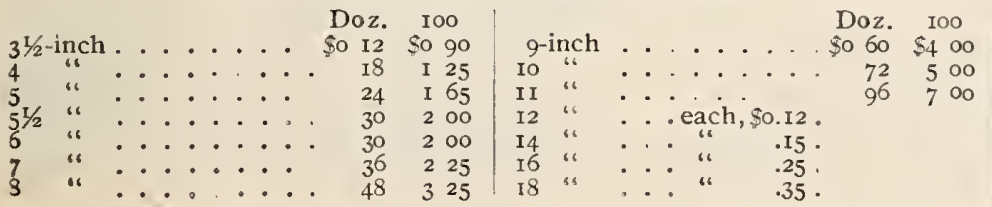

\section{Tin=Foil}

We have on hand a large supply of this. We sell at low prices in any quantity to suit the purchaser.
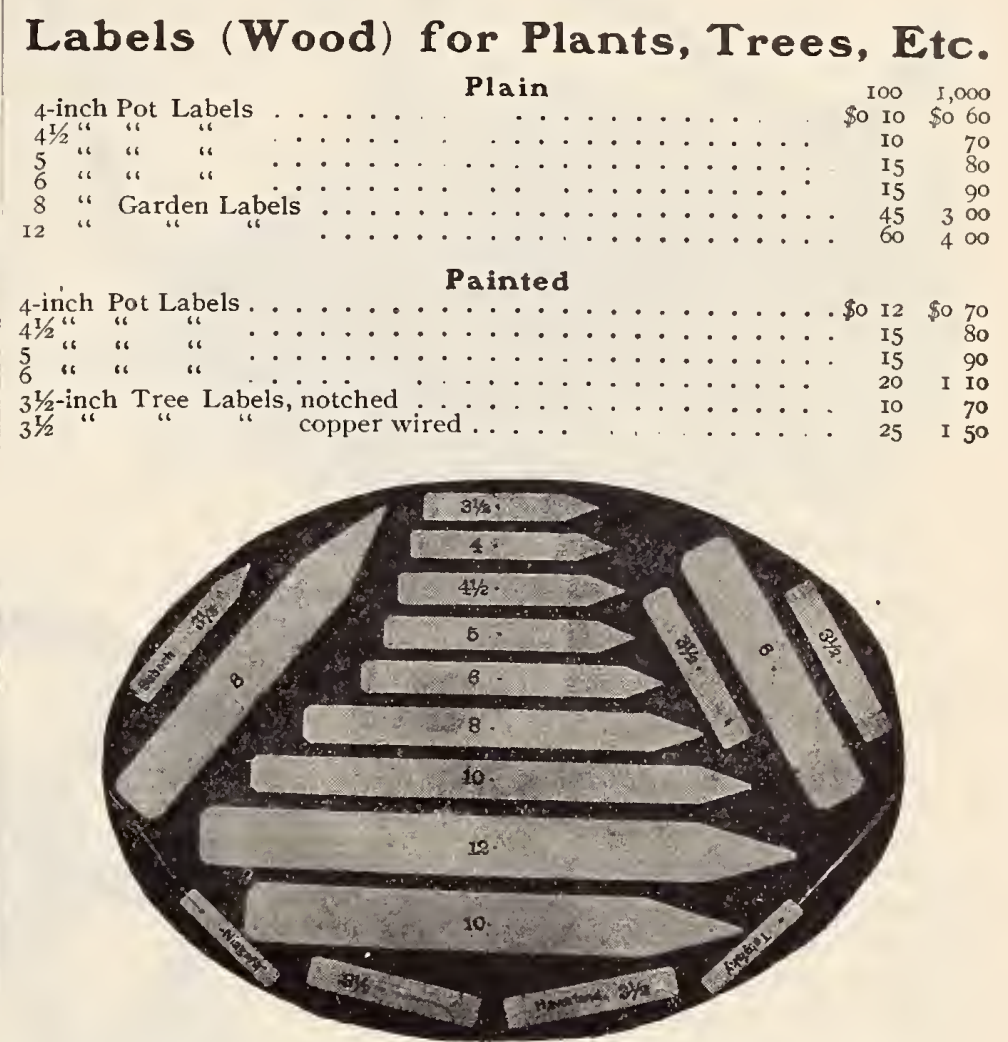

\section{Plant Stakes-Round, Tapering, Painted Green}

5 fi. 200 g $\times$ s/s in. dia.

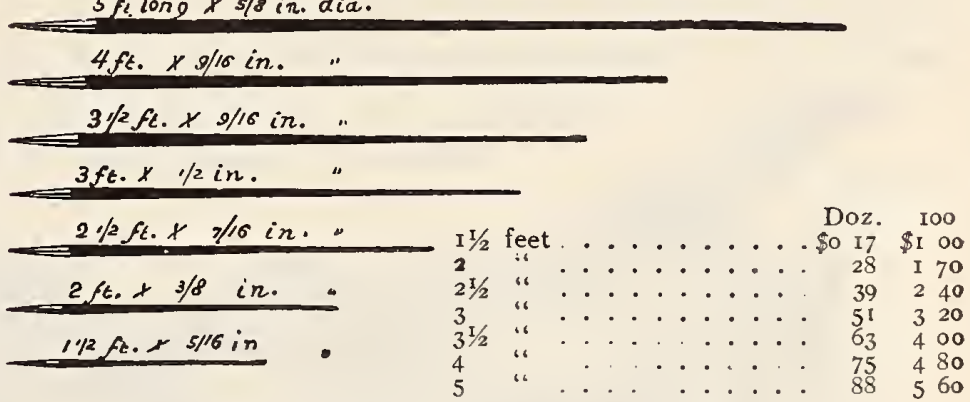

Heavy, Green Painted, Round

Suitable for Dahlias, Hollyhocks, and all plants requiring strong support.

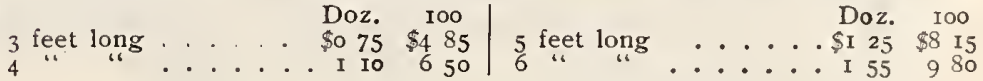

\section{Neponset Paper Flower Pots}

Are manufactured of water-proof paper, unbreakable, hand some, light and cheap. They are made so as to admit plenty of air to the roots and to give sufficient drainage. Not less than $I, 000$ at 1,000 rate.

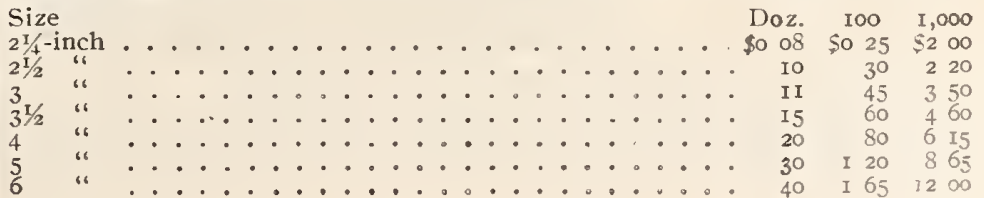




\section{The Townsend Triple Rachet Horse Lawn=Mower}

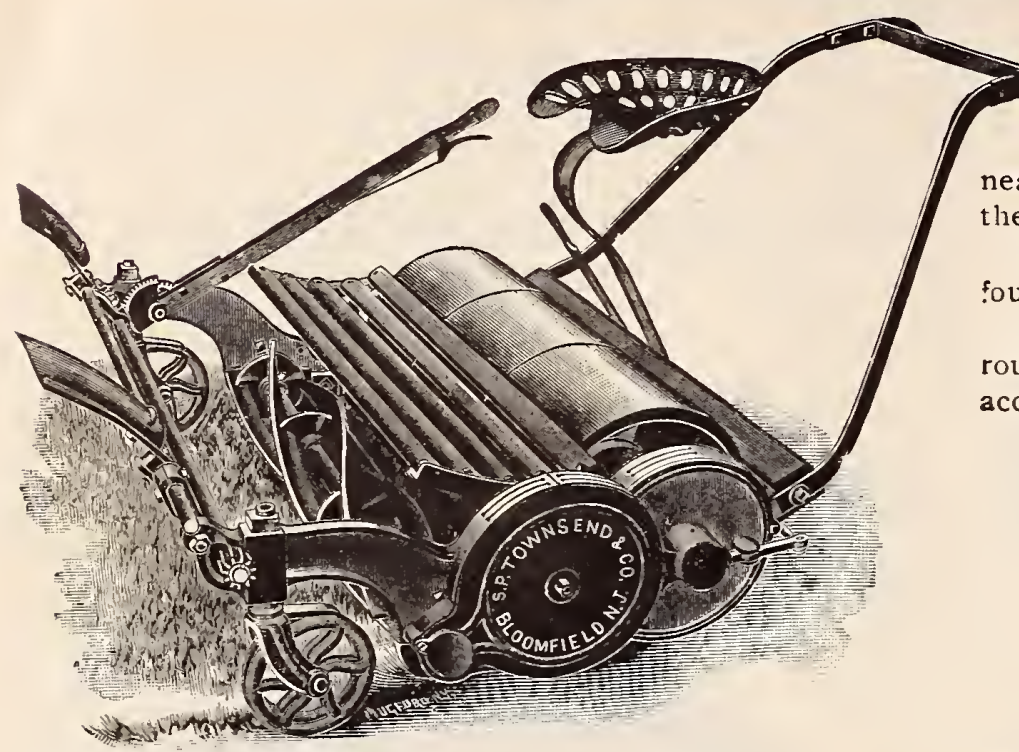

TRIPLE ROLLS, with triple pawls in each roll, making the most powerful driving mechanism ever put in a LawnMower. A lever beside the driver enables him to cut any height from the ground. A slight movement of a small lever near the driver throws the Mower in or out of gear without stopping the horse.

Self-aligning JOURNAL BOXES. A very valuable improvement, found in no other Mower. They prevent cramping of the journals.

It will cut over very rough and uneven ground, and stand very rough usage, and still cut its swath clean and smooth. It is on this account very popular with golf clubs.

Made in 30- and 38-inch width of cut

Townsend Triple Rachet Fiorse Lazen-Mow'er.

\section{Townsend "Victory" Lawn=Mower}

It has BALL BEARINGS of the very highest grade, exact to one-thousandth part of an inch, which reduce the friction astonishingly. A 24-inch Mower can now be operated as easily as the old parallel-bearing Mower only 16 inches wide.

TRIPLE GEAR, entirely enclosed, prevents dirt and cut grass from clogging.

A SOLID RECTANGULAR FRAME, that cannot be twisted or jarred out of parallel.

DOUBLE STEEL RACHETS, like lightning in action, cause the knives to cut the in-

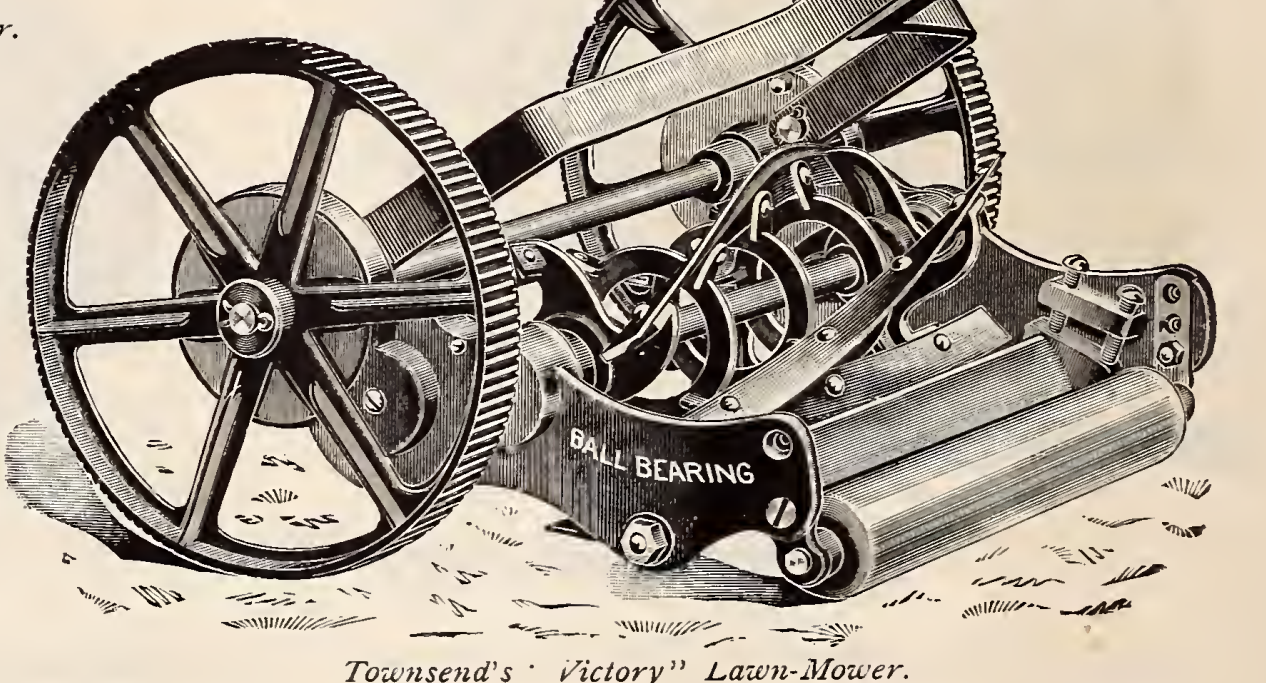

stant you move the Mower. ro-inch wheels,

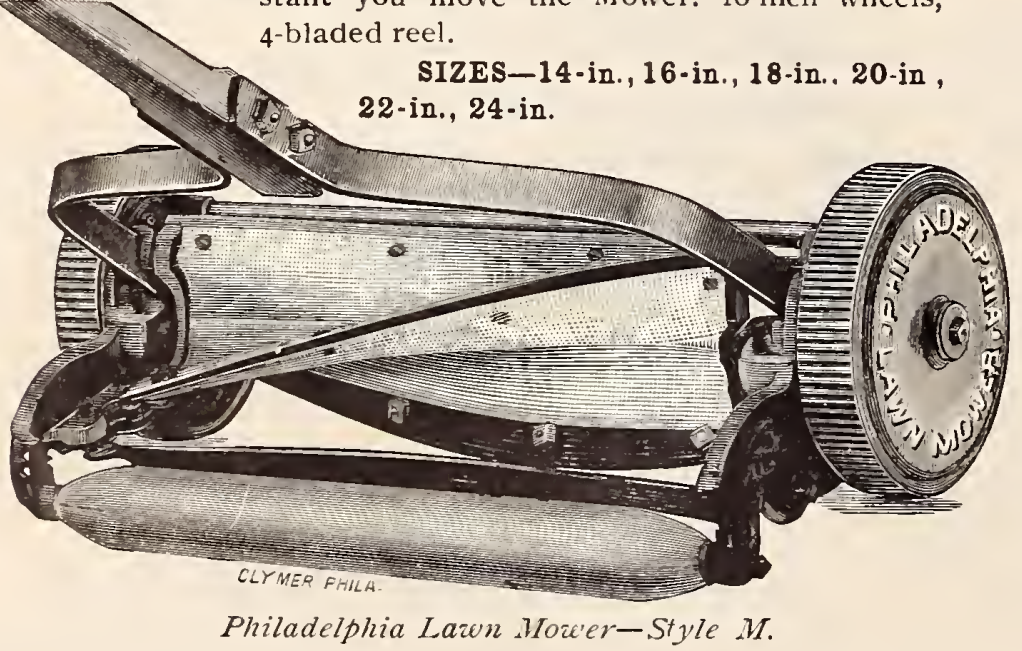

\section{Philadelphia Lawn Mower STYLE M \\ Three-Blade Solid Wiper, with the Steel Blades Bolted on}

This is one of the standard Mowers, and we know it will please you. This Mower is very popular for general purposes and adapted for rough and uneven grounds, as well as the finest smooth lawns.

\section{Palmer's Hotbed Mats}

WOOL-FILLED, FROST-PROOF, INDESTRUCTIBLE, CHEAP, WARM

Made expressly for winter covering of hotbeds, coldframes, plants and seeds of all kinds. Will not harbor mice or vermin. Easily handled. Dry out quickly after rain. Have been in practical use for years. Cost less than old-fashinned straw mats, and entirely take the ir place.

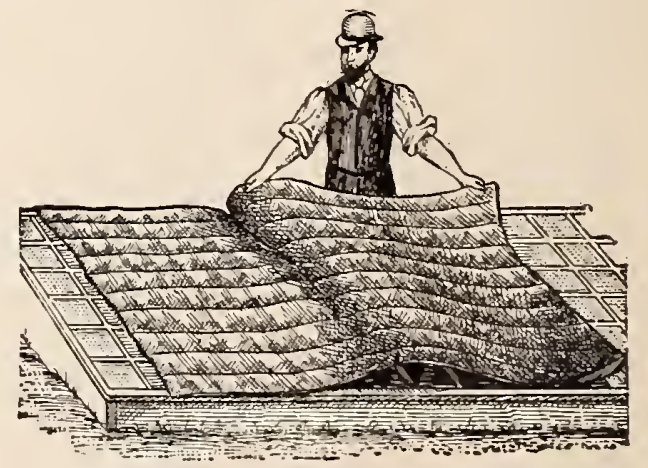




\section{The Worcester Lawn Mowers}

We are pleased to be able this season to offer these well-known Mowers to our customers. For several years we have been desirous of handling these Mowers, but were unable to do so until now.

We have recently made arrangements with the Worcester Lawn Mower Company, and the coming season will find us prepared to meet all demands. Ever since Lawn Mowers were invented we have sold them, including almost every make that was of merit; and year after year the fact has been made very plain to us that the demand for Lawn Mowers called for three grades (these grades, of course, each cutting the various widths).

FIRST:-A low-priced Mower which would be well made,

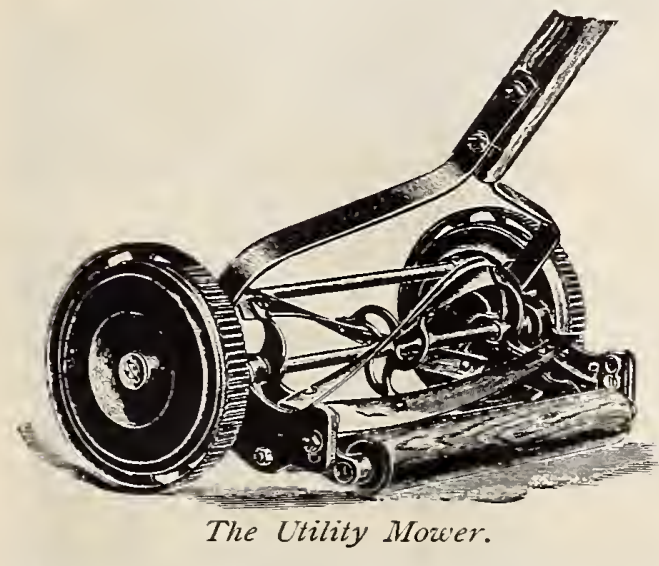
durable, do good work, simple and not liable to get out of order.

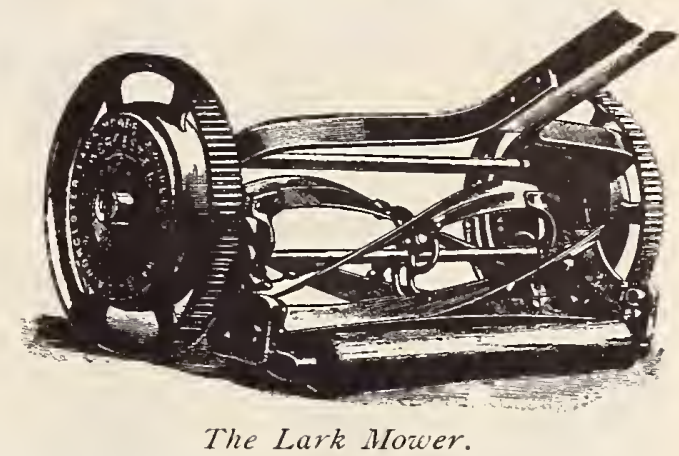

\section{THE LARK}

Mower will meet all these requirements. Plain-Bearing Drive Wheel, 8 inches, three tempered tool-steel knives on reel. Sizes, I2-, I4-, I6and 18 -inch cut.

SECOND:-A Mower of medium price; a Mower made of good material; a Mower that a person with a good-sized lawn could use day in and day out for the season without visiting the Lawn Mower repairer.

With all feeling of, confidence we offer you

\section{THE UTILITY}

for this grade. Either Plain or Ball-Bearing Drive Wheel, 9 inches; four tempered tool-steel knives on reel. Sizes, I4-, I6-, I8- and 20-inch cut.

THIRD:- The trouble has been that this grade has been too high-priced, but we now offer you a Mower . that is excelled by none and equaled by few. A Mower that is high-grade in every respect; a Mower that embraces the results of 20 years' experience. Material, workmanship and style, will place

\section{THE RHODY}

in the front rank of the leaders. Ball-Bearing Drive Wheel, Io inches; four tempered tool-steel knives on reel. Sizes, I4-, I6-, I8and 2o-inch cut.

\section{LAWN MOWER REPAIRS}

We have the repairs for the Lawn Mowers we sell. No waiting two or three weeks, or sometimes not getting them at all, like hundreds of cases that come to us every year. Remember, that for the Mowers we sell you can get your repairs, and get them at once.

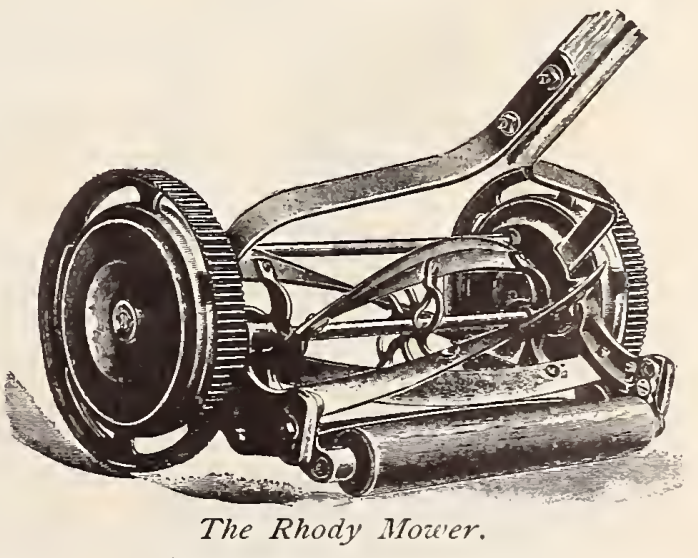

\section{Hann Automatic Grass Catcher}

Will fit any lawn mower; strong and durable, quickly detached to empty. Also the Simplex Metallic Bottom, which is practically the same in detal, except the metal bottom.

\section{The Gem Lawn Sweeper}

This machine will clean your lawn more thoroughly and quickly than three men can do it with hand rakes, and it will greatly benefit the turf. Its use throughout the summer will keep your lawn in good healthy condition.

\section{Horse Lawn Boots}

They prevent the horse sinking in damp or soft places, and do not cut or tear up the turf. We have the best makes at reasonable prices. 


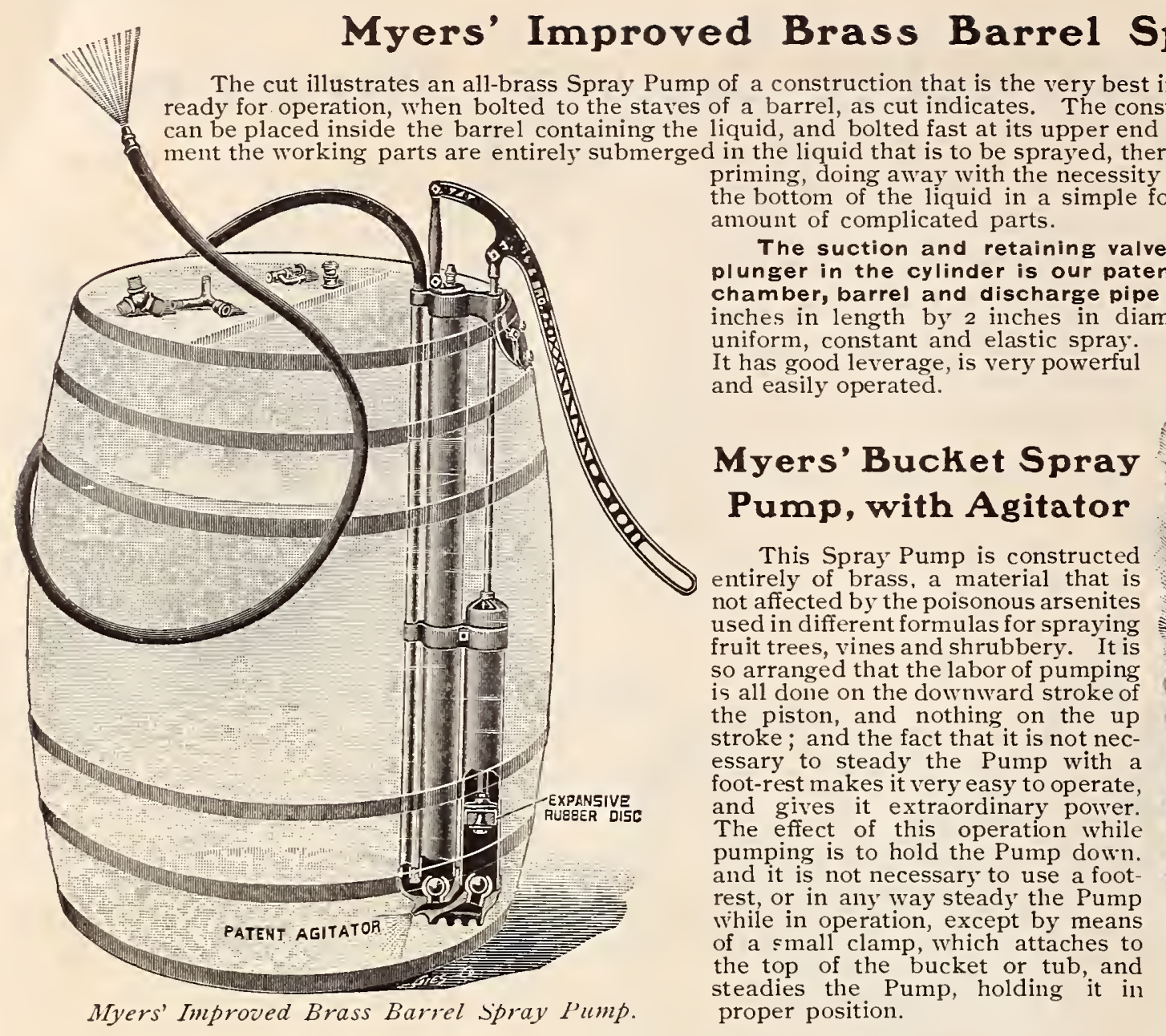

\section{Spray Pump} The construction is such that the entire Pump can be placed inside the barrel containing the liquid, and bolted fast at its upper end to the barrel staves. By this arrangement the working parts are entirely submerged in the liquid that is to be sprayed, thereby avoiding all possibilities of losing the bottom of the liquid in a simple form, and also doing away with a large amount of complicated parts. (2) expansive form; the cyllnder, air , t has good leverage, is very powerful

\section{Myers' Bucket Spray} ump, with Agitator

\section{"Auto=Spray"}

A SELF=OPERATING, or AUTOMATIC SPRAYER

The "Auto-Spray" has a capacity of four gallons, and when properly charged contains three gallons of solution and one gallon of compressed air. Eight to twelve strokes of the plunger will compress the air and two pumpings will discharge the entire contents. Three gallons of solution, or one charge, will easily cover one-half acre of potatoes or other similar crop.

\section{The "Rapid=Easy" Garden and Field Weeder}

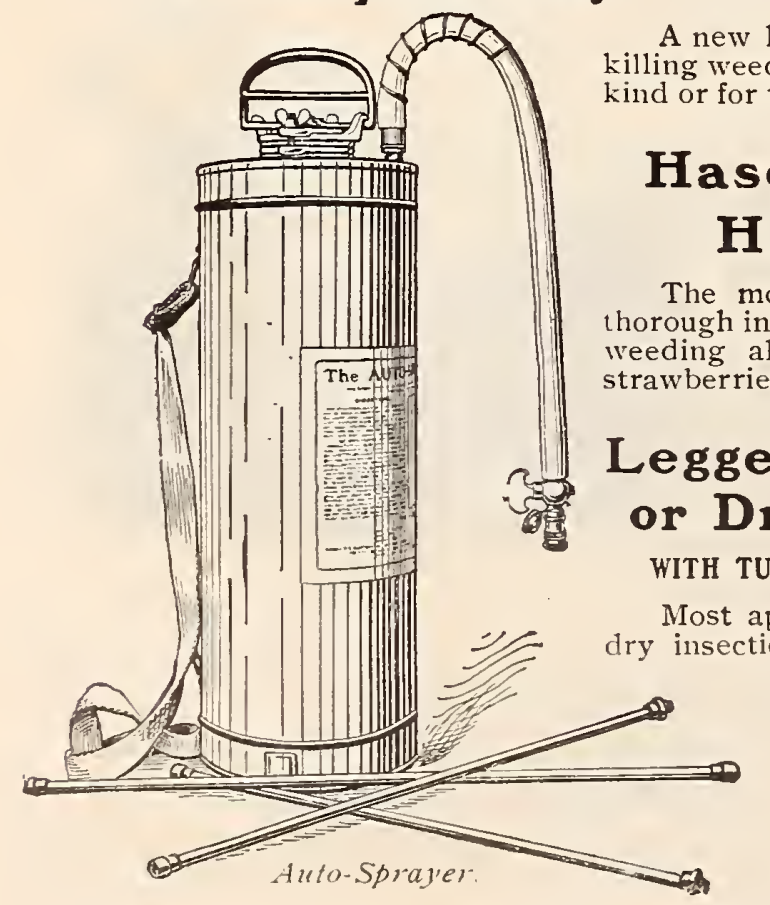

\section{Haseltine's Patent Hand Weeder}

The most durable, most rapid, nost horough in its work. Perfectly adapted to veeding all kinds of vegetables, flowers, thes and small plants of every kind

eggett's Paris Green, r Dry=Powder Gun

WITH TUBES, NOZZLES, STRAPS, ETC.

Most approved method of distributing

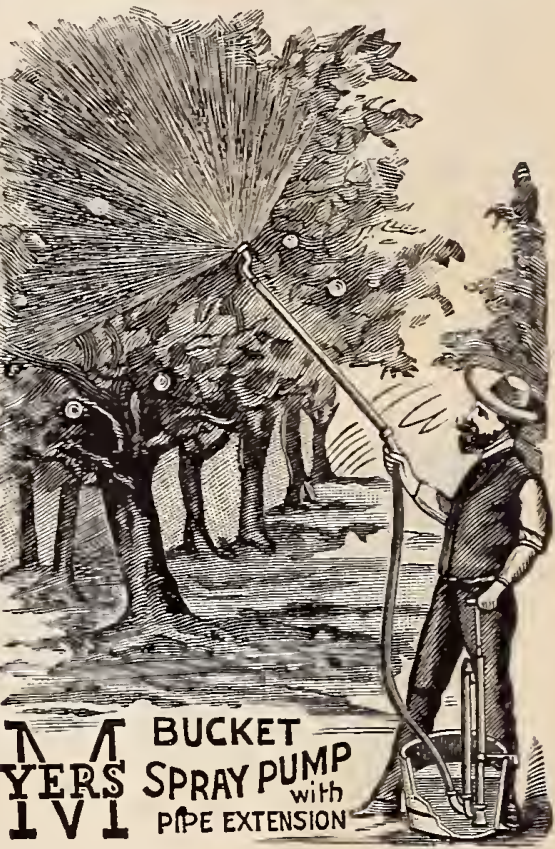




\section{Acme Powder Gun}

A simpie, practical implement for the extermination of potato bugs and all kinds of insects, flies, etc., the pests of every house and garden. It will handle all insecticides in their dry state-pure Paris green, hellebore, Persian insect powder, etc. It is very effective in the destruction of potato bugs, currant worms, and all like pests, and for the wholesale destruction of house flies,

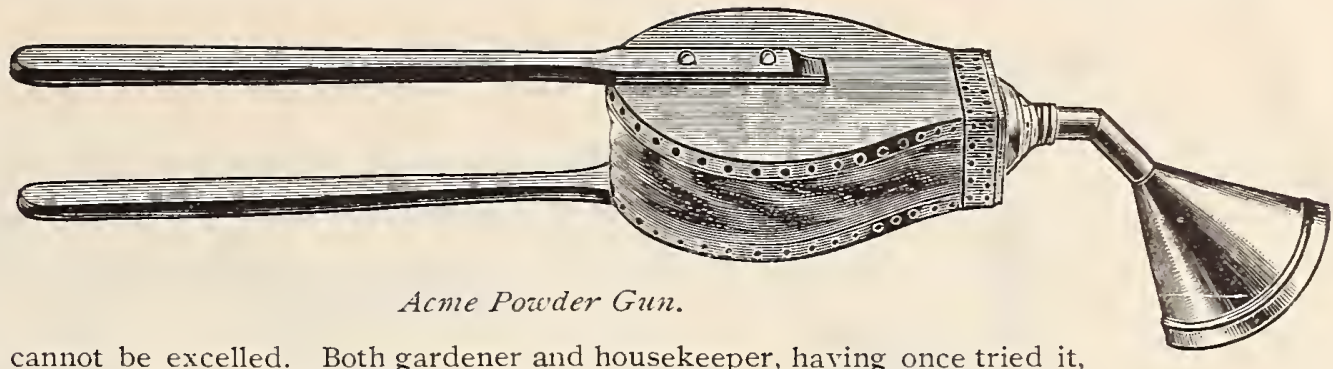

using freshly ground Persian insect powder, cannot be excelled. Both gardener and housekeeper, having once tried it,

will bless the day on which this little implement was brought to their notice.

\section{Acme Sprayer}

This Sprayer is adaptr. for erery kind of insect killing and spraying purposes. There is no insect living that this machine will not kill when the right ingredients are used. It is a great saving of labor, and also a great saving of liquids, as the spray is as fine as mist,

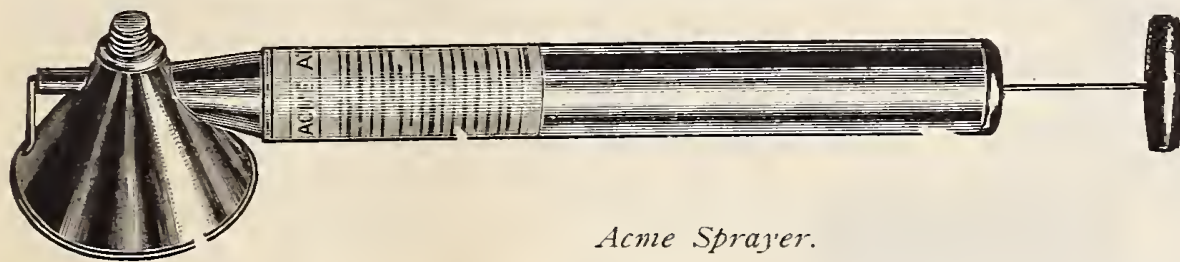
and adheres to the plant. It is highly recommended by florists and gardeners, as well as by every lady who has used it for house plants. Also, by stock-raisers, for keeping flies from cattle and horses during the summer months. Fine, also, for killing plant-lice, fleabeetles, aphides, green-fly, mealy bugs, etc., such as attack cabbage, melons, squashes, cucumbers, plum trees and small fruits of all kinds. Use kerosene emulsion. It is safe and very effective.

\section{Wheelibarrows}

There is no article that has such general and hard usage as the Wheelbarrow; consequently it is of the utmost importance to have only the best, as in the long run they prove the cheapest. Our Barrows are made of carefully selected hard woods, strongly braced and thoroughly ironed throughout. We offer these Barrows in four sizes, each of which will be found perfectly adapted to the use for which it was intended.

\section{The Wire Lawn $=$ Rake}

Reversible; all steel; heavily tinned; best that is made. Head is of No. I6 fine cold rolled steel bent in the stiffest form, in which the teeth are

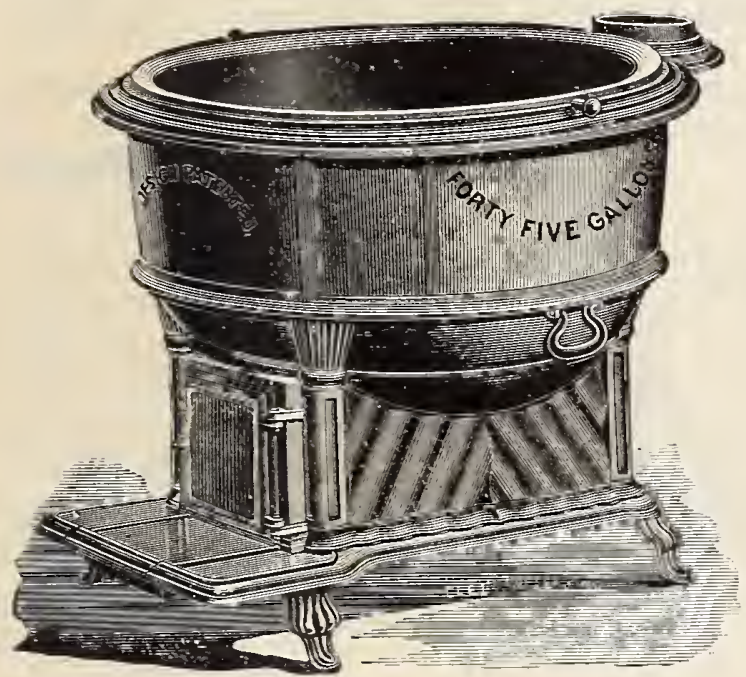

Furnace and Caldron securely held. Socket is firmly secured without rivets or weld, guaranteed to be secure. Handles of ash, finely. polished. The Rake runs smooth; its teeth will not tear the sod or clog with grass or leaves.

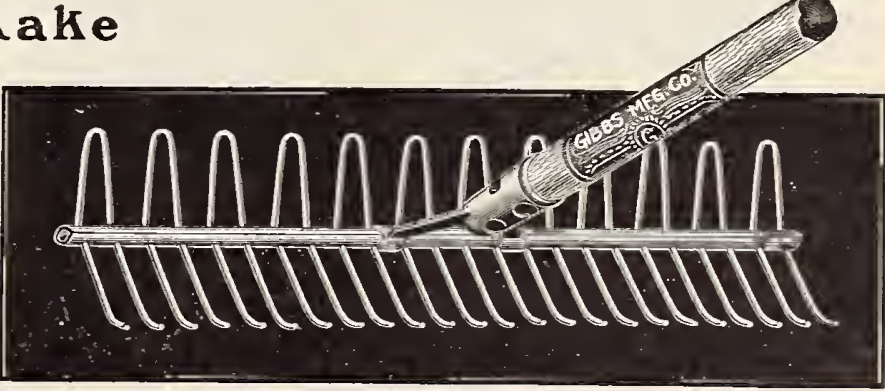

The Wire Lawn-Rake.

\section{Furnace and Caldron}

Our Furnaces and Caldrons are made in seven sizes, for hard or soft coal or wood. The flues are so constructed that the heat is directed against the whole surface of the Caldron at the same time and none wasted. The Furnaces are set on legs and provided with handles, so they can be set anywhere, outof-doors as well as inside, and fitted with smoke-pipe and are instantly ready for use. It is of suitable length for wood and for coal, is provided with coal grate and heavy substantial brick. These Furnaces and Caldrons are used by butchers, farmers, cheese makers, stock raisers, hotel keepers, bakers, brewers chemists, druggists, dyers, painters, laundries, chandlers, and for various other agricultural and manufacturing purposes.

\section{Steel Land Rollers}

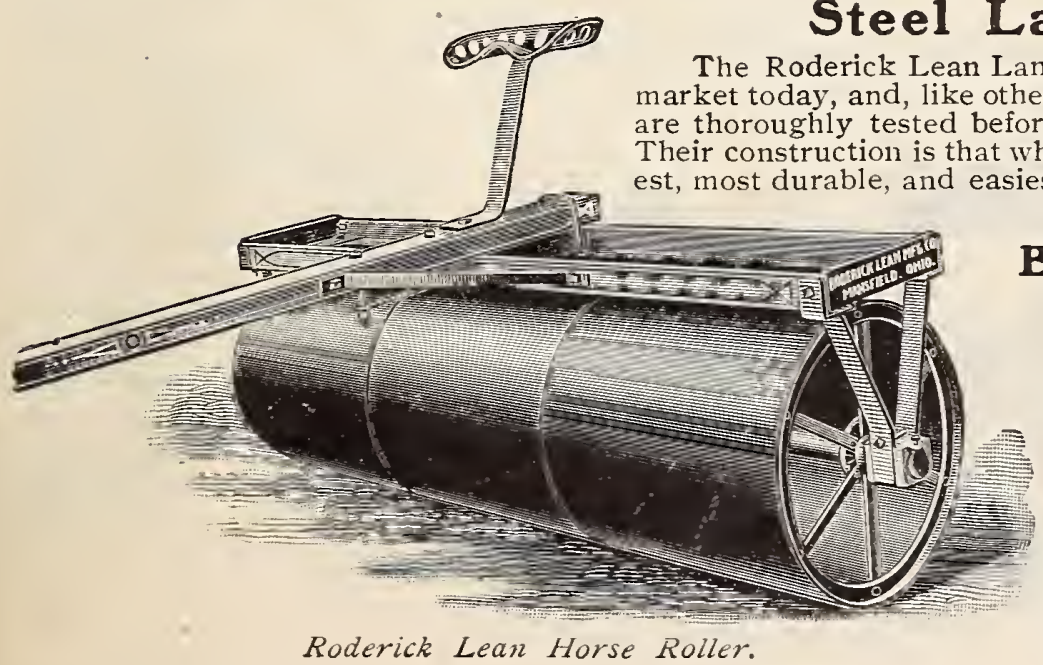

\section{Best Hand Steel} Lawn Rollers

The sections are made of smooth rolled steel without projection or roughness of any kind to gather soil or grass. The handles stand erect automatically. The rims are cushioned to prevent breakage and deaden $t$ he disagreeable noise common to ordinary Roderick Lean Horse Roller. Rollers when in use.
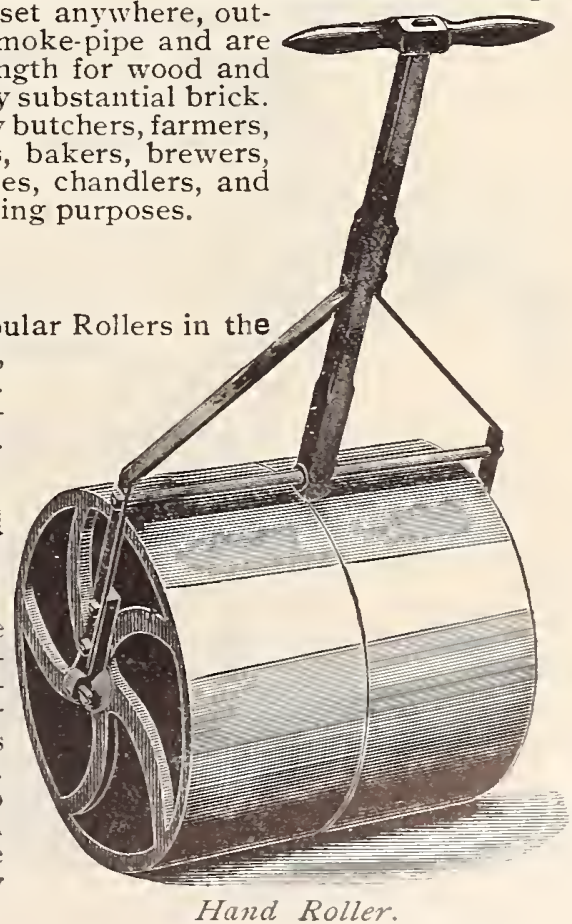


\section{Agricultural Implements, Etc.}

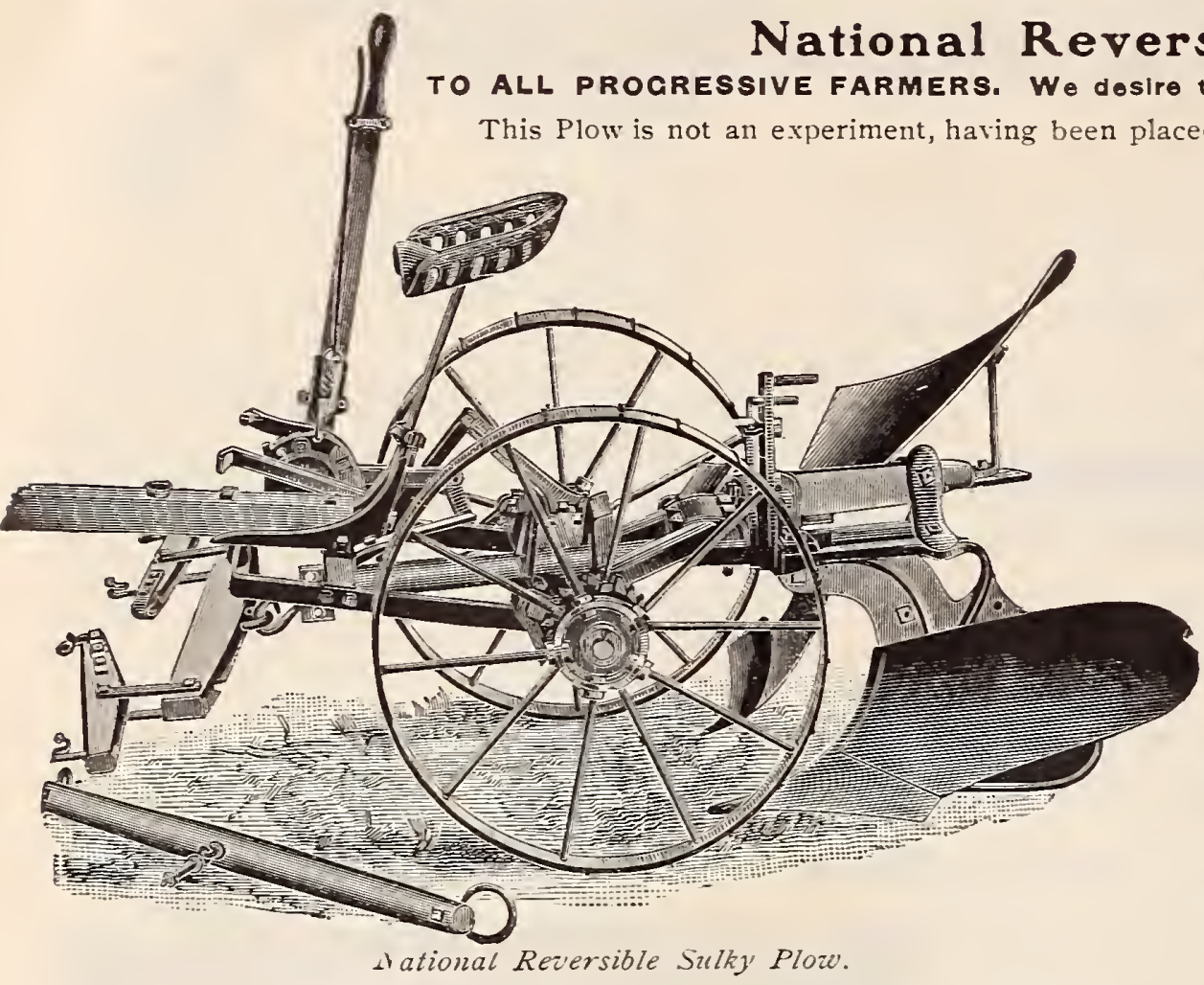

upon the market several years since, in which time there have been several thousand sold. Unlike all other makes of Riding Plows, the National has been especially designed to meet the wants of all farmers, and succeeds not only upon level farms, leaving them without tracks or dead furrows, but is equally adapted to stony, rough sidehill farms, turning the land with the slope, and not up the hill as is the case with all one-way Sulky Plows. We believe the National Sulky Plow can justly lay claim to being a success for all kinds of work and in all varieties of soil. Extra points, neck yokes, evener, whiffletrees, which answer for two or three horses abreast, are sent with each Plow. Either jointers, straight or rolling coulters are furnished, but, if not otherwise ordered, jointers will be sent with each Plow.

\section{Syracuse Reversible Sulky Plow}

STEEL MOLDBOARDS AND LANDSIDES

This is the lightest draft Sulky Plow on the market. Will plow on sidehill or level ground and leaves no dead furrows. As shown in cut, two plows are used (only one being in use at a time). Throwing the Plow in and out of the ground is done by the team while the operator has control of the width of furrow with his feet, leaving both hands free to handle the team. The wheels alway's stand perpendicular and the plows level. This tool is designed for New England farmers and has stood the test for ten years. We have sold hundreds of them. Cuts 3 to 9 inches deep, I I to 16 inches wide; weight, 556 pounds. We furnish two sets of points and two-horse hitch.

\section{Syracuse Two=Horse Landside Plows}

We carry a full line of these Plows and would call your attention to the No.62. These Plows are modeled after the Yos. 3 I and 32 , but are made with a removable chilled iron

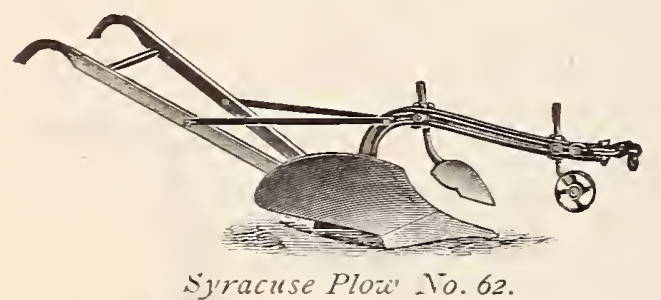
shin-piece. This shin-piece detaches easily: being locked at the lower point and held in place by one bolt. Nade with highly tem-

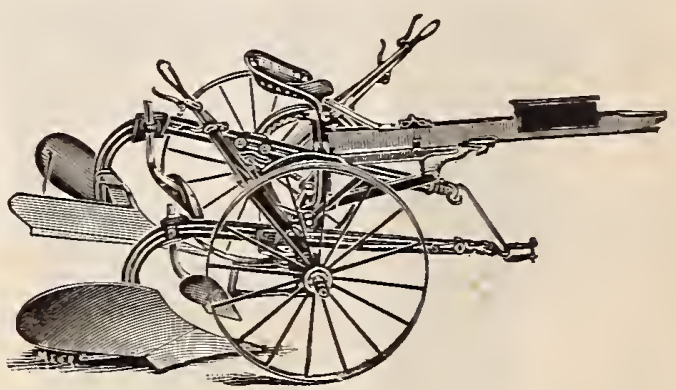

Syracuse Rezersible Sulky Plou'. pered soft center steel moldboard only. In this Plow we have a combination of strength, durability, light draft and excellent turning capacity, at a low price. These plows take the same share, handles, handle braces, cross-bar, wheel, clevis, jointer and colter as the Nos. 3 I and 32 .

\section{Oliver Patent Chilled Plow}

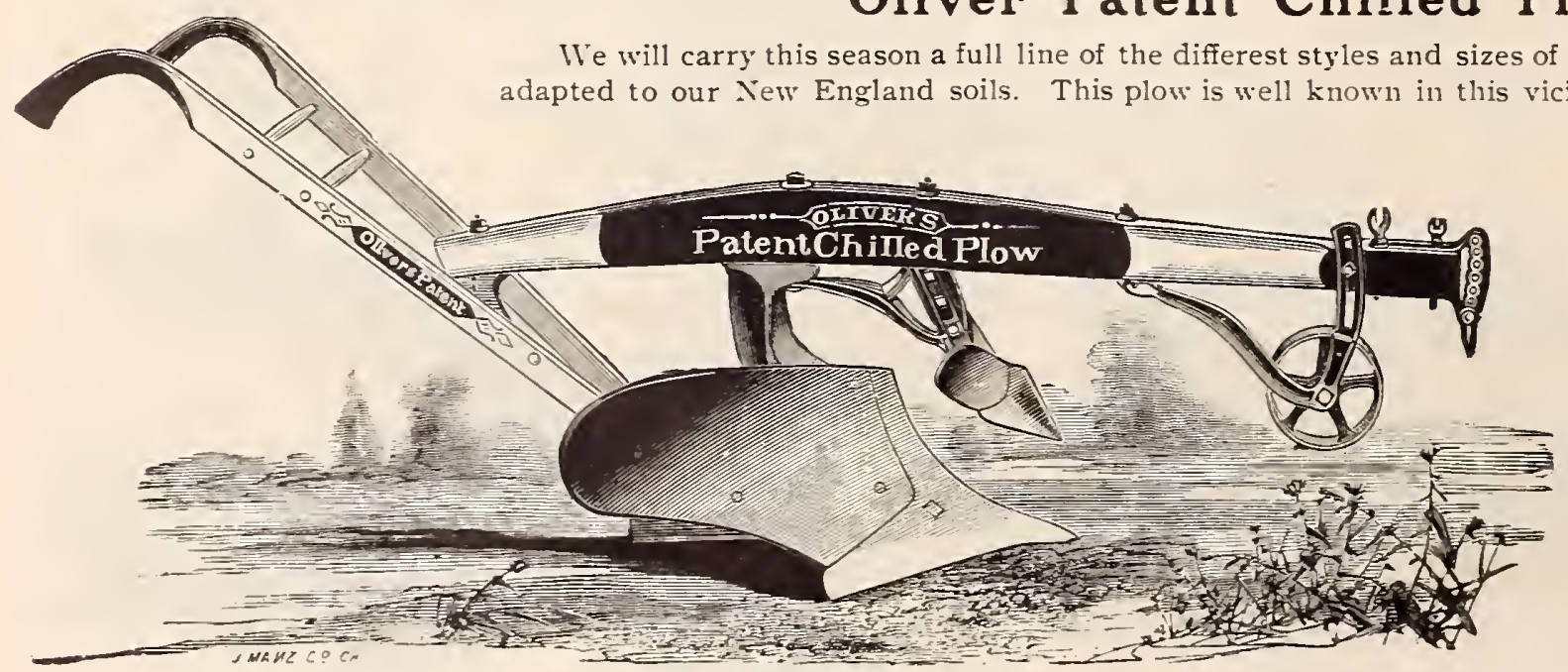
praised too highl r. Remember that every Plow made by the Oilver Chilled Plow works is offered with the absolute guarantee of being the best article of the kind that can be made for the price asked. Every Genuino Oliver Chllled Plow has stenciled on the woodwork the inscription: "Manufactured by the Oliver Chilled Plow Works, South Bond, Indiana, U. S. A. 


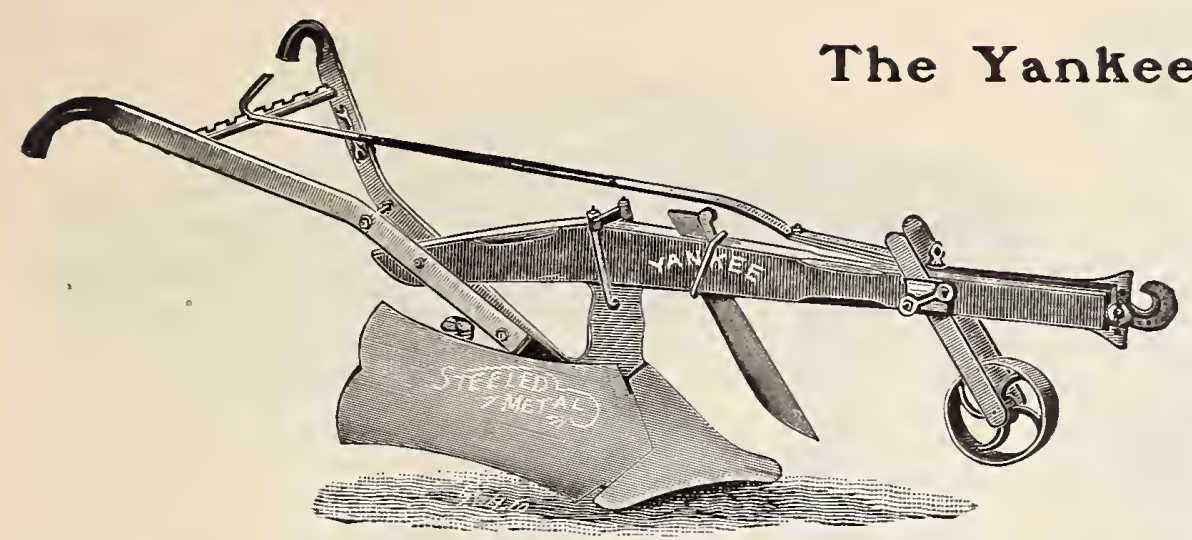

\section{Swivel Plow}

New Series, with Patent Spring Foot-Latch, Automatic Jointer, Straight Steel Coulters, of Rolling Castor-Coulters and all late improvements

The construction of this Plow is such that when used with straight coulters all grass, weeds, etc, are buried as effectually out of sight as can be done with jointers on other Plows, with a saving of at least io per cent less draft.

Nos. $2 \mathrm{H}$ and $3 \mathrm{H}$ are made as shown in cut, with high standards and patent spring foot-latch. This latch is an invaluable improvement, as, being operated entirely by the foot, the Plow is ready for work as soon as reversed, which is done without taking the hands from the handles, or stopping the team.

It is simple, strong and durable, and does not get higher, there is more room under the beam, and there is less danger of clogging when plowing weedy land. out of order. The standard on these Plows being

\section{The Arlington Swivel Plow}

The Arlington Plow has become a favorite in many sections. Moldboards are made of patent steeled metal, and all castings nicely polished. The beam and handles are made from selected stock. Their general appearance commends them to all desirous of a first-class, easy-working Plow.

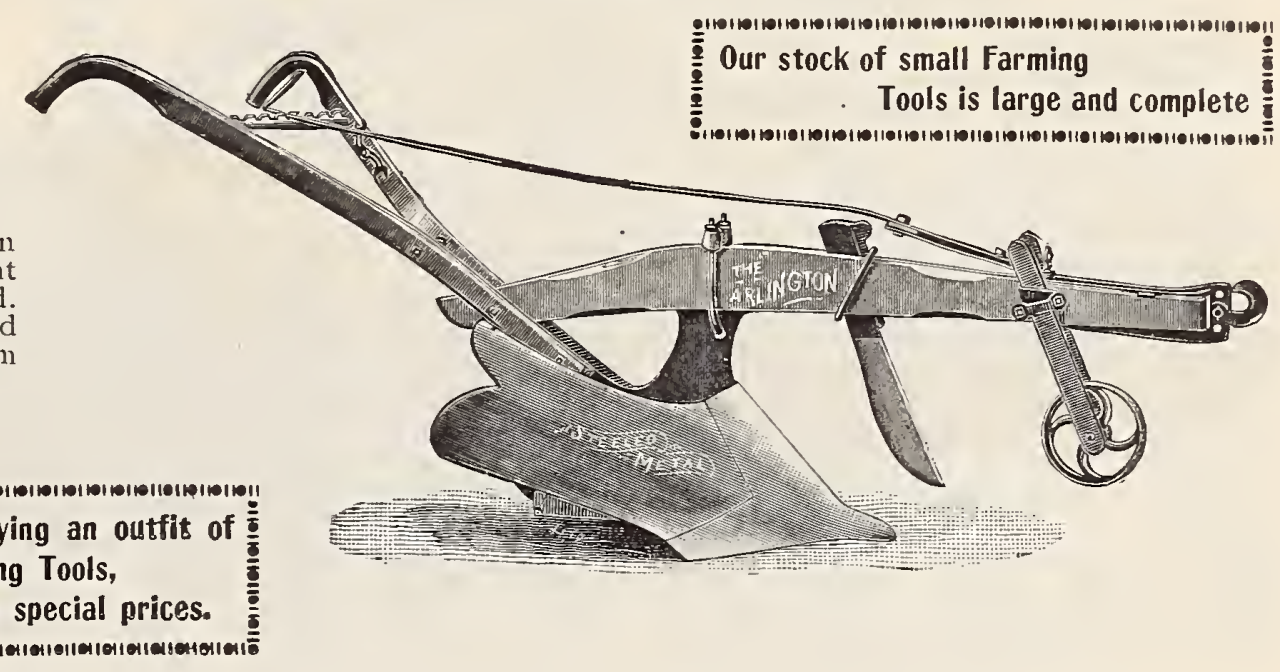

\section{The Conical Plow}

The fact that since we first introduced "The Conical" we have made and sold over 10,000 of this kind of Plows, should be a good recommendation for it. The increased demand for this Plow shows the strong hold it has among the farmers. For all kinds of soil and good work it has no equal.

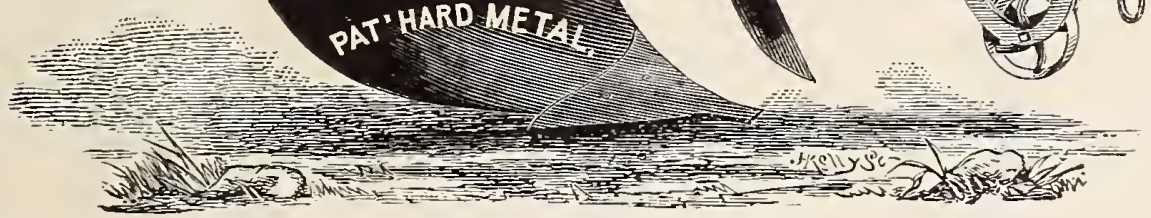

\section{Eddy "Rough and Ready" Plow}

This Plow is rightly named, and thus far has been found equal to any test put to. It has forged steel beam, made of two bars. Steel riveted together and bolted to standard. It has chilled mold-board, and superior turning qualities.
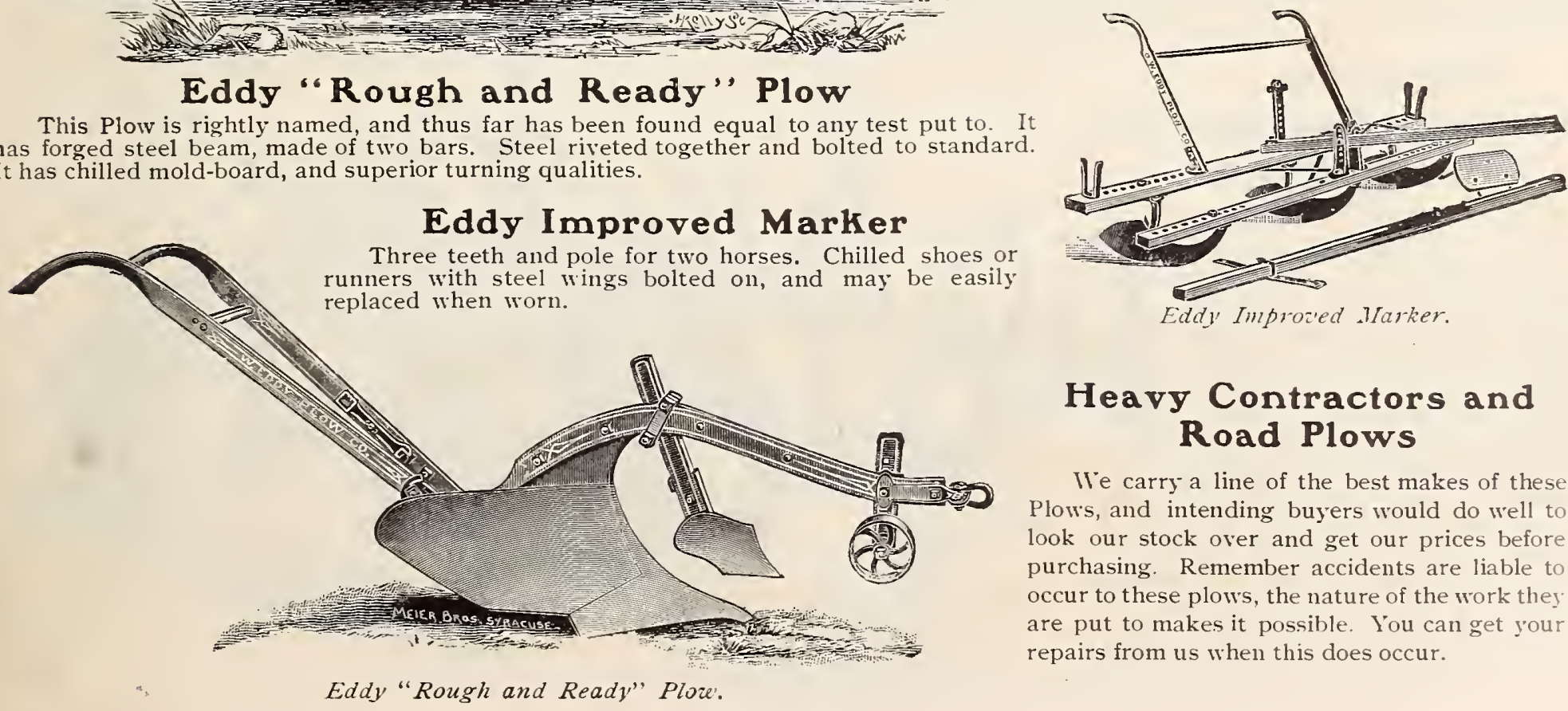

\section{Heavy Contractors and Road Plows}

We carry a line of the best makes of these Plows, and intending buyers would do well to look our stock over and get our prices before purchasing. Remember accidents are liable to occur to these plows, the nature of the work they are put to makes it possible. You can get your repairs from us when this does occur. 


\section{Bell's Center $=$ Cut Disk Harrow}

The Only 0verlapping Center-Cut Disk Harrow in the World

There is no farming tool that covers and cultivates so much ground as a good Disk Harrow, but they are all so made that a little uncut ridge of ground is left in the center. How to reach that ridge and cultivate an even surface has been the problem. It is now solved by Bell's Center Cut. It is the only Harrow that reaches the center ridge and pulverizes all the ground from outside to inside, leaving a smooth surface behind it. The importance of this sure cultivation to an even depth and leaving no ground uncultivated cannot be over-estimated. All centercut Harrows have one more disk than other Harrows. "When the ground Is uncultivated, the crops won't grow, but weeds wills"
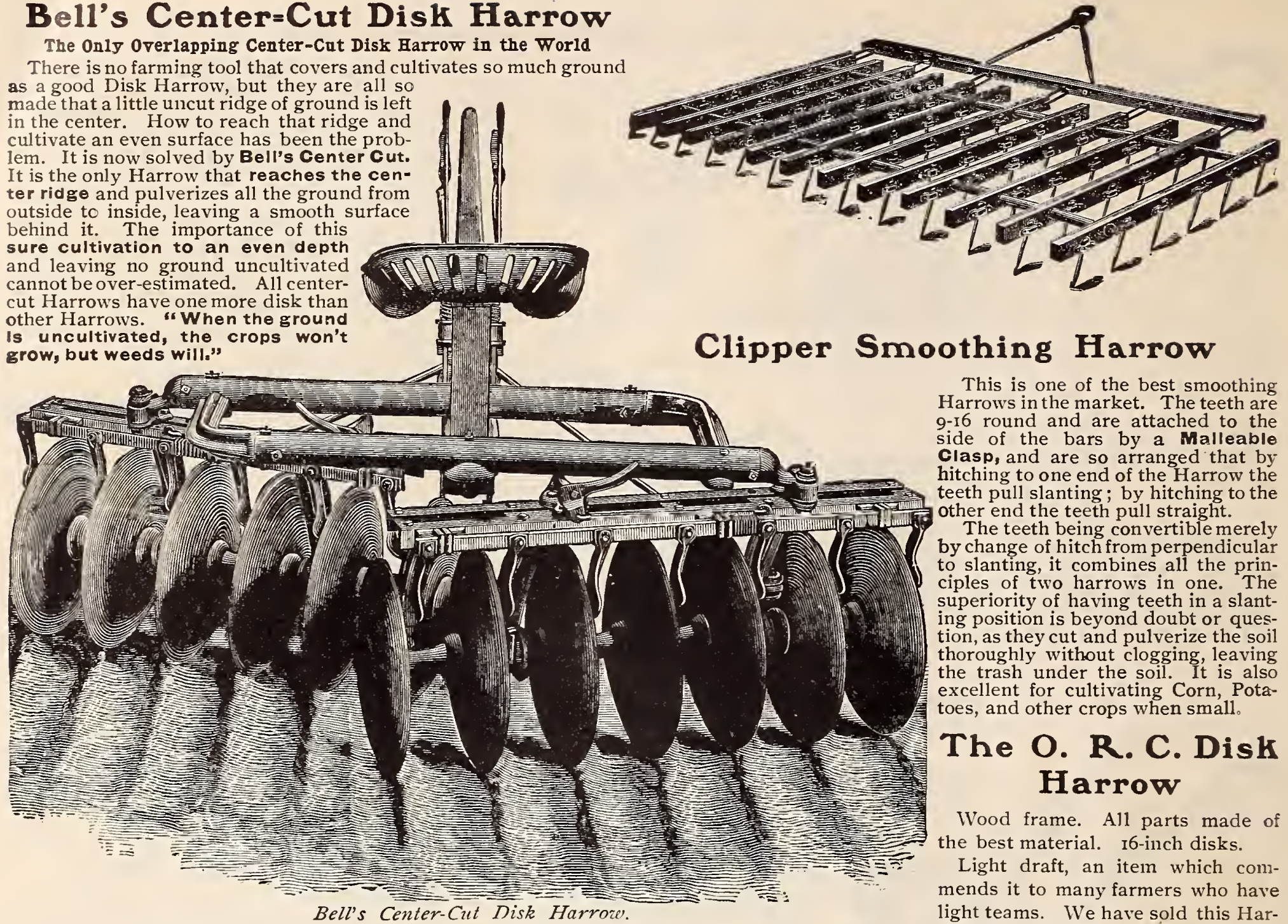

\section{Acme Pulverizing Harrow}

This is not a special tool, as some have supposed, but as its name implies, a general-purpose harrow that will do the whole business, viz.: it will crush, cut, lift, turn, smooth and level, all in one operation. Made for one or two horses.

\section{Improved Imperial Spring= Tooth Harrow}

Elevated Frame

As now manufactured is a tool that for completeness, simplicity and durability in structure and ease of manipulation has no equal. Made of all steel and malleable iron, its strength and lasting qualities cannot be excelled. Drawbar attachment such that with rear attachment, no lateral or side-toside motion, but allowing of upand-down or in-and-out-of-theground motion, same as in a flexible harrow. Distance between frame such that no trash can collect. Arrangement of teeth such that no two teeth track or line up.

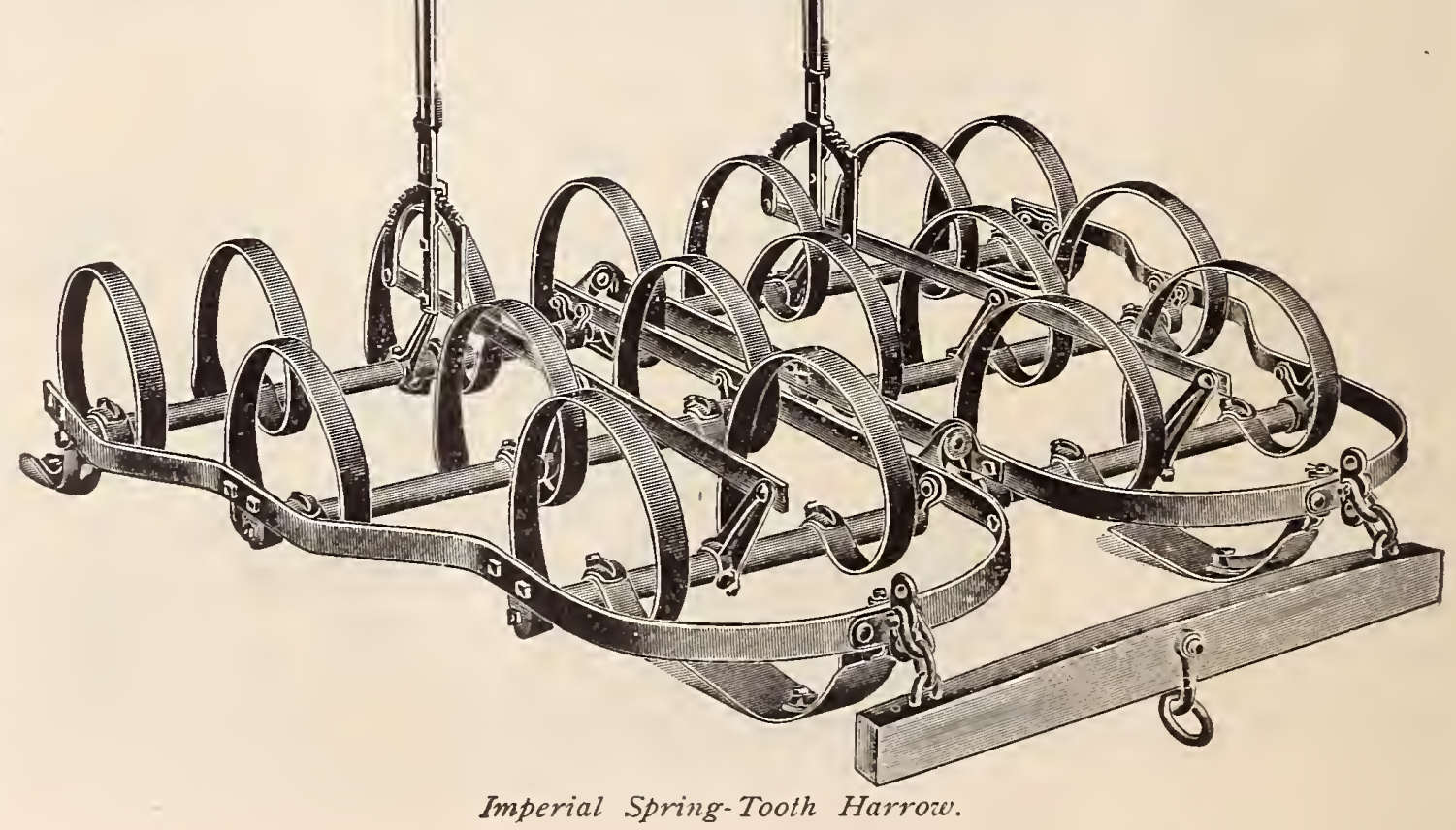

This is one of the best smoothing Harrows in the market. The teeth are 9-16 round and are attached to the side of the bars by a Malleable Clasp, and are so arranged that by hitching to one end of the Harrow the teeth pull slanting; by hitching to the other end the teeth pull straight.

The teeth being convertible merely by change of hitch from perpendicular to slanting, it combines all the principles of two harrows in one. The superiority of having teeth in a slanting position is beyond doubt or question, as they cut and pulverize the soil thoroughly without clogging, leaving the trash under the soil. It is also excellent for cultivating Corn, Potatoes, and other crops when small.

\section{The O. R. C. Disk} Harrow

Wood frame. All parts made of the best material. I6-inch disks.

Light draft, an item which conmends it to many farmers who have light teams. We have sold this Harrow for many years and can guarantee it in every respect.

Imperial Spring-Tooth Harrow. 


\section{The Evans Potato Planter}

\section{WITH OR WITHOUT FERTILIZER ATTACHMENT}

This machine is one of our specialties, and, without doubt, is the most improved machine of its class on the market, being strictly up-to-date in every particular.

The Feed. This being the most important part in seeding machines, and especially so in potato planters, we have constructed the feed so that there is no adjustment for large or small pieces of potato. It is a force-feed, is positive in its action, and its operation is controlled by the machine, instead of by the size of the seed potatoes

To Change the Distance Apart in Dropping. The machine will drop the potatoes in dril.s 10, $12,14,16,18,20,28$, or 36 inches apart. The change for the different distances apart is accomplished by putting on more or fewer picker arms.

The Driver Can See the Potatoes Dropping. This is a great advantage, as he then knows whether the machine is depositing the seed properly or not.
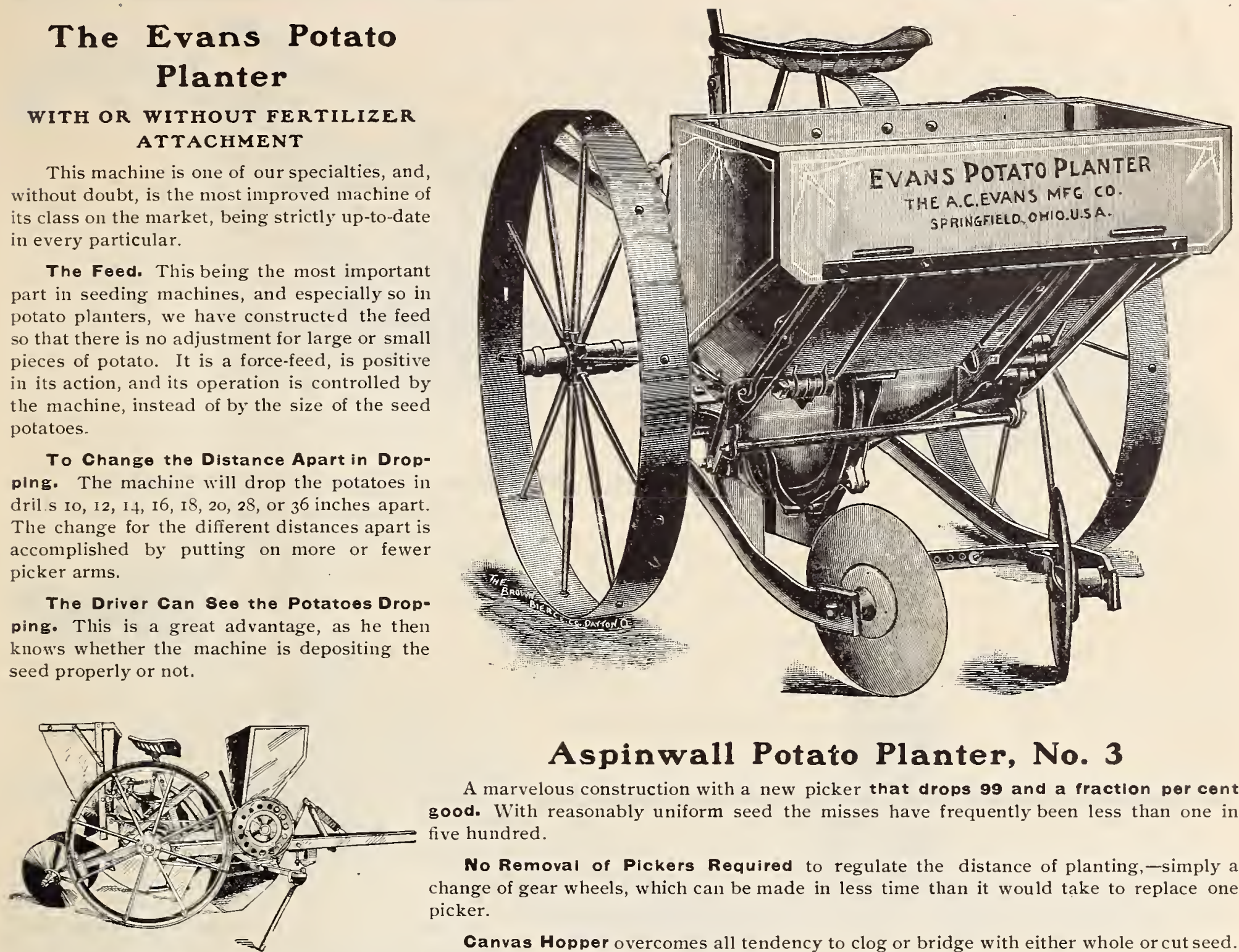

\section{Aspinwall Potato Planter, No. 3}

A marvelous construction with a new picker that drops 99 and a fraction per cent good. With reasonably uniform seed the misses have frequently been less than one in five hundred.

No Removal of Pickers Required to regulate the distance of planting,-simply a change of gear wheels, which can be made in less time than it would take to replace one picker.

Canvas Hopper overcomes all tendency to clog or bridge with either whole or cut seed.

Both the Feed and Coverer Tension are Regulated from the Seat. No removal of bolts-simply turning a thumb-screw does the work.

The Fertilizer Attachment which has given such excellent satisfaction for the past six years will be used on the No. 3 Planter. Rotary force feed. Capacity from 200 to 2,000 pounds per acre. Fertilizer deposited in bottom of furrow thoroughly mixed with the soil-preventing the seed from coming in contact with the fertilizer.

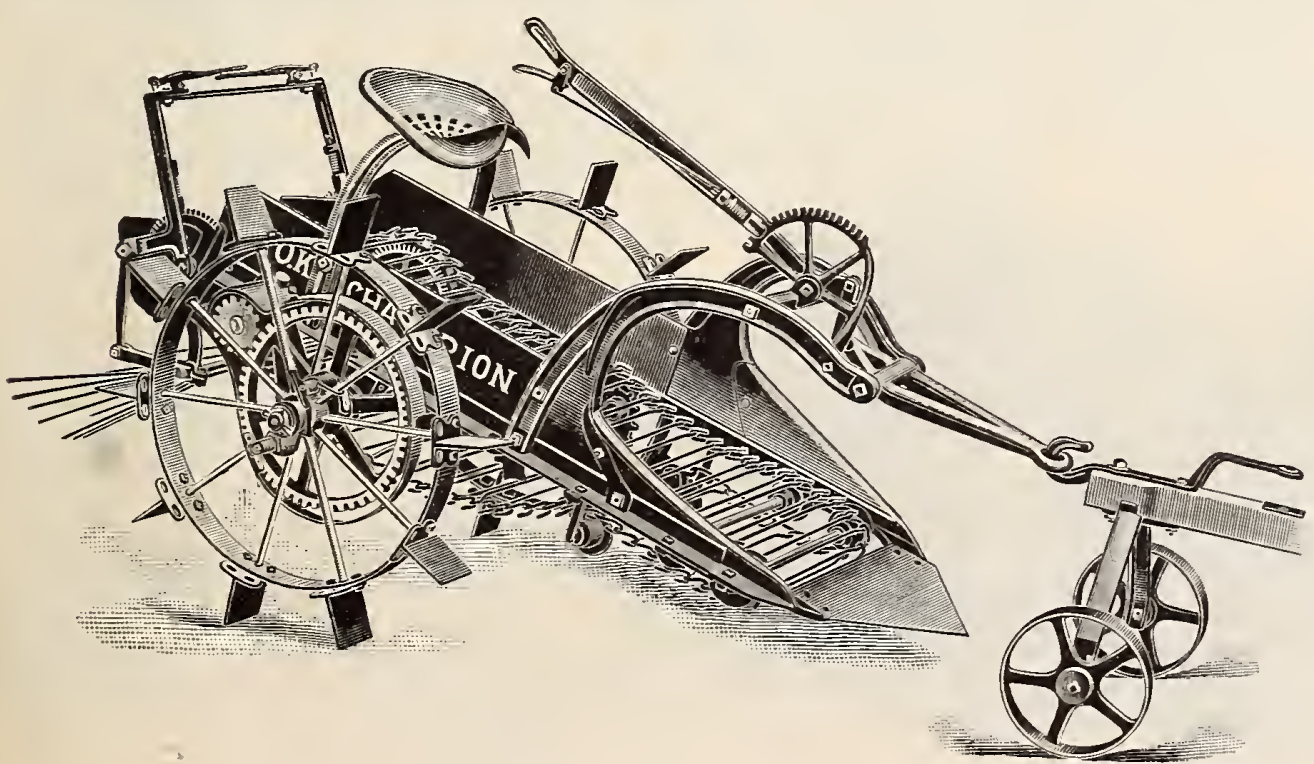

\section{The O. K. Champion Potato Digger}

The O. K. Champion Potato Digger has a great many points in its favor that cannot be found on any other machine. Its simpleness, embodying the scientific principle of separating the dirt from the potatoes with the least possible power requirements; the shovel, 20 inches wide, scooping up that width of ground and potatoes, depositing it on the elevator and separating carriers, which are raised and lowered alternately and are run over a sprocket agitator, giving it an enormous capacity for separating. After leaving the elevator the potatoes are run over a successful shaking fork rower which cleans the potatoes of any dirt remaining and deposits them in a neat row behind the machine. 


\section{Eureka Potato Digger}

Contains many common-sense, valuable features, designed expressly for the farmer with a limited acreage of potatnes who cannot afford to invest in a hundred-dollar machine and cannot afford to dig his crop by hand. It is sold at a low pi ice and will do good, practical work, leaving the potatoes on top of the earth in a very satisfactory manner. In fact, its work is preferable to many of the higltpriced diggers.
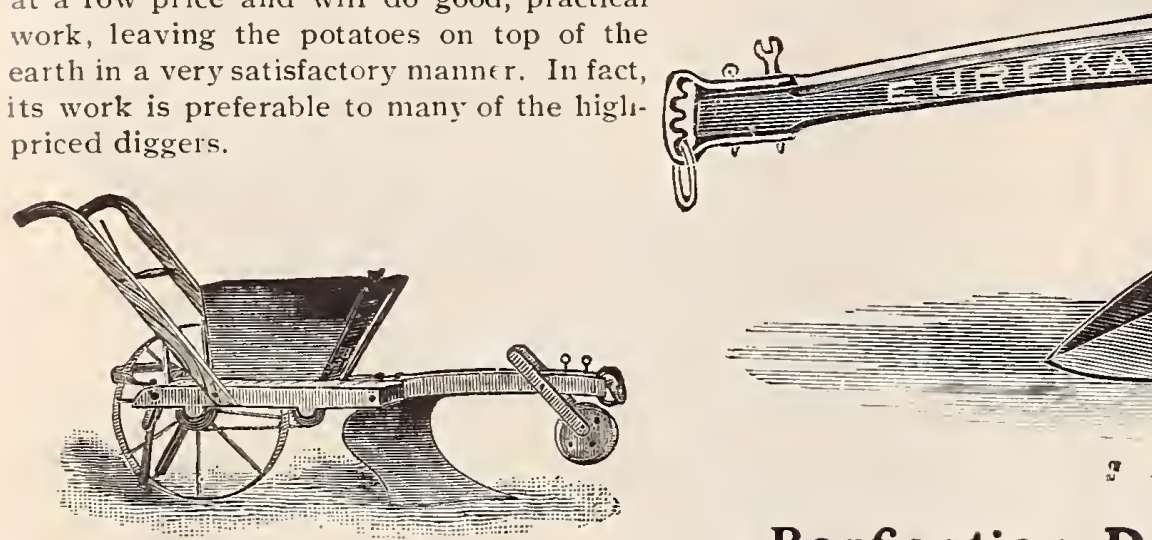

Perfection Drill and Fertilizer Sozer.

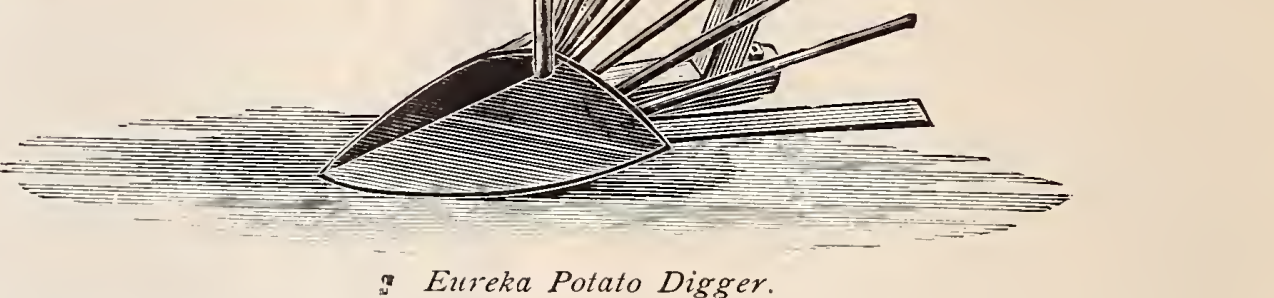

\section{Perfection Drill and Fertilizer Sower}

This machine will form a drill from 3 to ro inches deep and will drop into the drill com. mercial fertilizers at the rate of 100 to $3,000 \mathrm{lbs}$. per acre as desired. The scrapers shown between the wheels are adjustably attached to the axle and can be placed where necessary to cover the fertilizer with dirt as destred. If preferred to mix soil with fertilizer, the tooth in the re $r$ of the machine can be used. The plow can be removed and also the gatherers under the hopper, and a space 10 inches wide covered with fertilizer and left on the surface or mixed with soil by using tooth and scrapers.
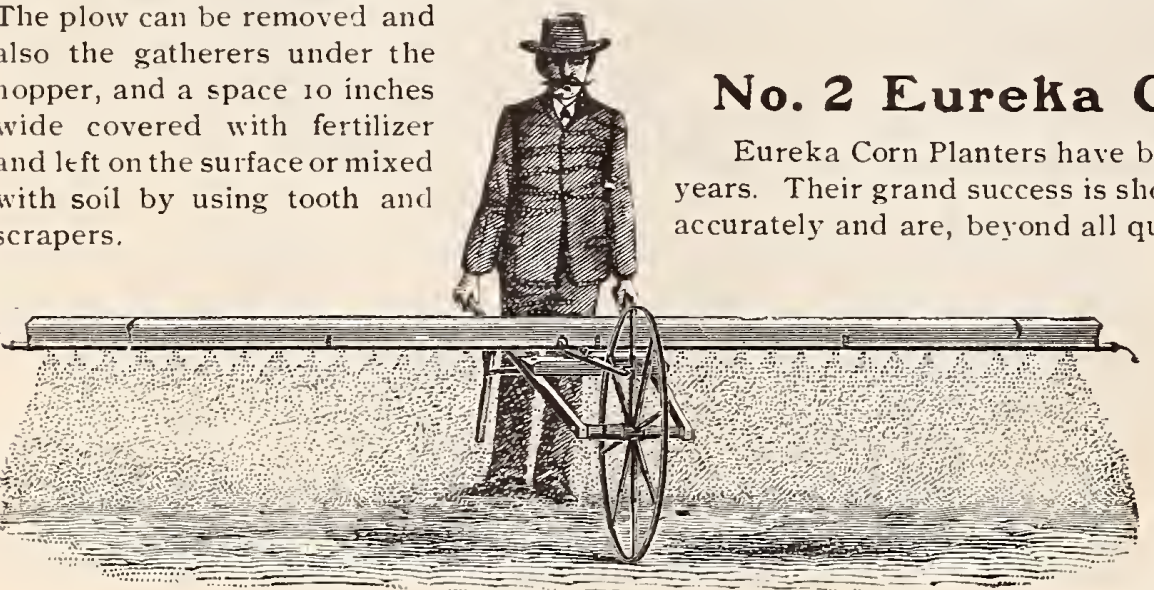

Thompson Wheelbarrow Grass Seeder.

\section{No. 2 Eureka Corn Planter}

Eureka Corn Planters have been on the market for eight

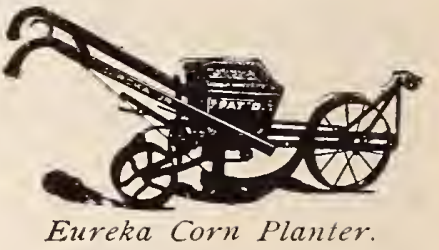
accurately and are, beyond all question, one of the best planters on the market.

\section{Thompson Wheelbarrow Grass Seeder}

This is the only correct way of broadcast-seeding. Seed can be sown on any kind or condition of suil, in any kind of weather, any amount per acre required, evenly and accurately. It can be used hy any one who can wheel a barrow. There are no cogs, gears or intricate connections in its entire construction. Mud cannot clog its parts. It is impossible for it to sow any way but accurately, as the entire working parts are governed by the wheel. Lightness and strength are combined in its construction, and the large wheel ( 33 inches in diameter) makes it very easy to run. The actual weight of complete machine is about 40 pounds.

\section{"King of the Cornfield" Corn, Bean and Pea Planter and Fertilizer Distributor}

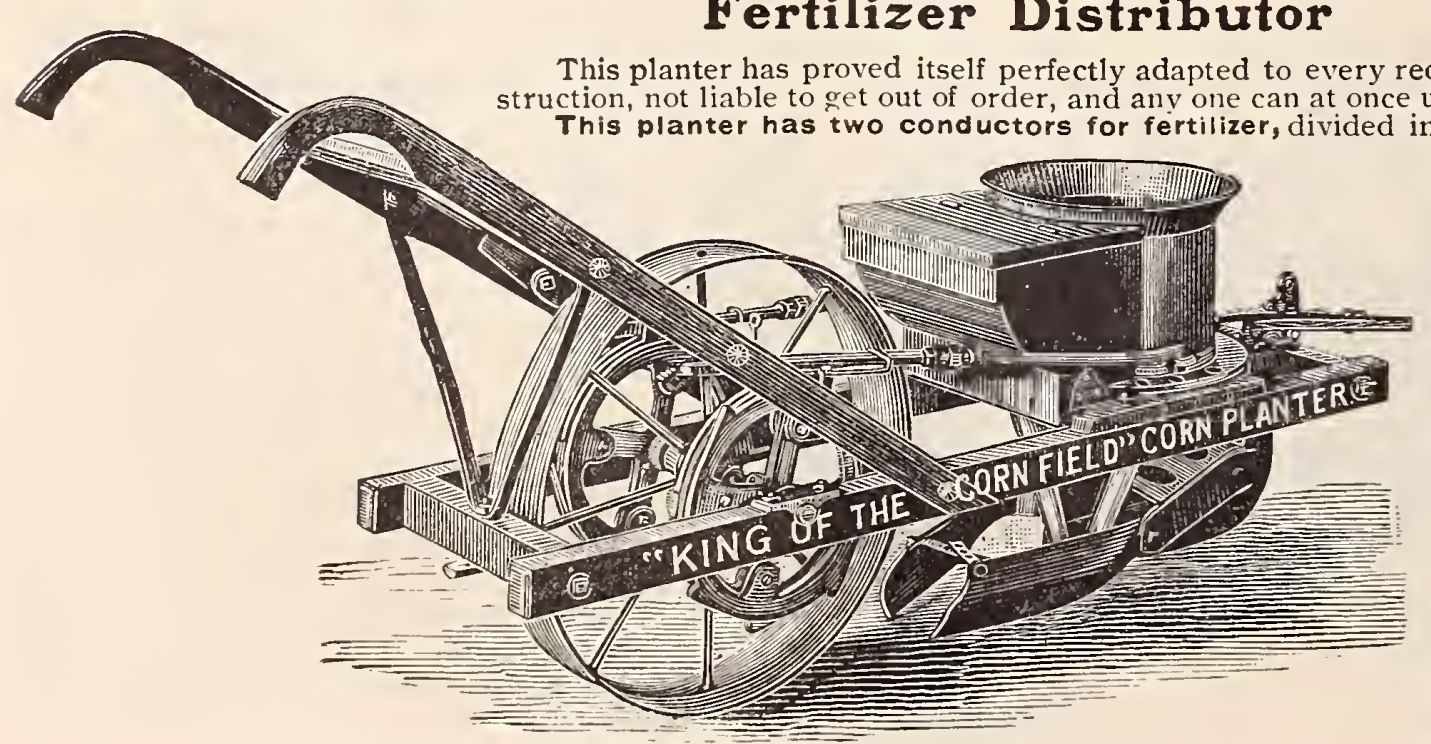
understand and manage it. such a way as to have it fall on both sides of the seed. The fertilizer hopper is an oscillator, vibrating backward and forward in order to pulverize all lumps, which allows wet or lumpy fertilizer to be used, distributing it in equal quantities as desired. It will drop ashes as well as ail commercial fertilizers, wet or dry, coarse or fine, which no other machine will do.

Plants field, ensilage, fodder and broom corn, beans, peas, pumpkins, beet or other like sized seed. This season several new and useful improvements have been added, among which we mention a new steel concave whetl, having substituted steel in place of cast iron for the coverers and clearing plow. New-style steel drive rods, improved covers in fertilizer hopper, etc., making the machine very much lighter and st ronger. 


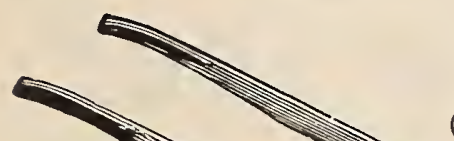

\section{Hallock Success Weeder}

Teeth are separately removable. Handles and shafts adjustable. Teeth are made of flat spring steel (round at lower end). The frame is angle steel, giving the Weeder by far the best frame on the market. It weighs no more than wood and is, of course, better in every way. Each tooth is remove the teeth over the rows if you wish, and in some cases this is very desirable.

\section{Keystone Weeder}

\section{Some Points of Superiority over Straight-Frame Weeders}

The "Keystone" is the only Weeder that is adjustable to depth and wldth. It can be used as a shallow cultivator, working close to the plants, between the rows, until the crops mature, long after other weeders are laid aside. The depth of cut is regulated by the wheel in front. It has no shafts that will hinder working close to the fence. It will not clog. The long curved, spring teeth are so placed and shaped that clogging is impossible. It can be weighted down; teeth will stand I5o lbs. pressure. Being $\mathrm{V}$-shaped, it is not only a stronger

tool than the straight-frame Weeders, but it adapts

Hallock Success Ireeder. itself much better to uneven surface.
to $71 / 2$ feet and narrowed to 30 inches.

\section{Eureka Flat Tooth Sulky Smoothing Cultivator}

SOLD WITH OR WITHOUT GRASS SEED ATTACHMENT

For leveling the ground, for pulverizing the soil, for preparing a good seed-bed, the Eureka Flat Tooth Cultivator has no equal. The depth of cut is under the control of

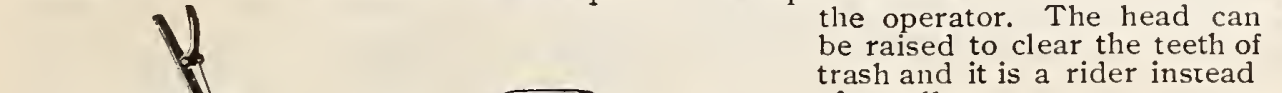

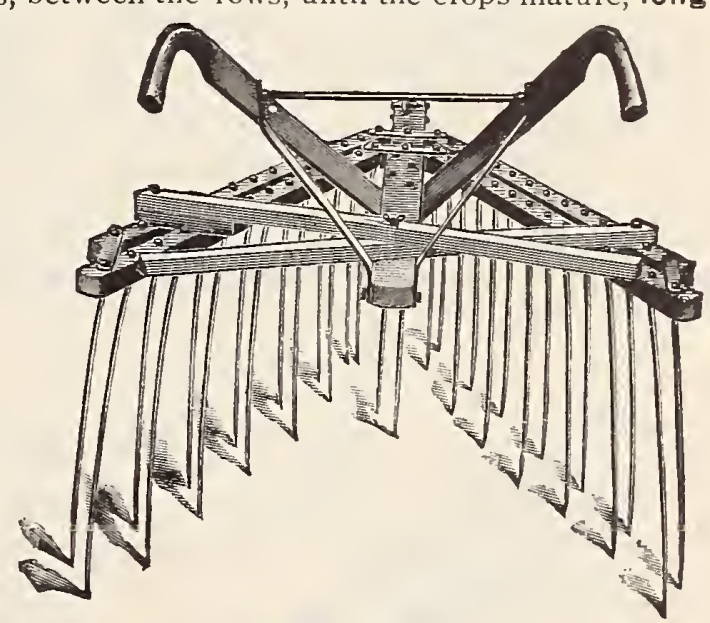

Keystone Weeder.

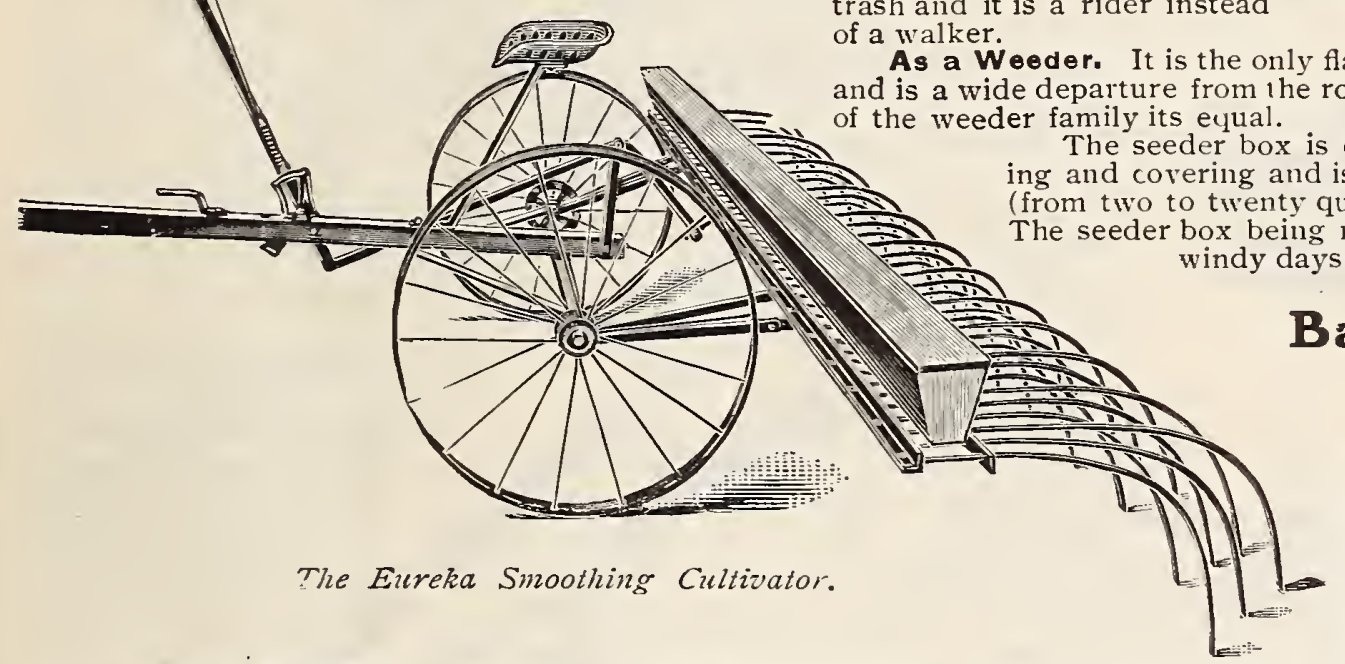

Baldwin Fodder Cutter (WITH CARRIER)

The cut below shows the No. I4 $1 / 2$ Bald. win Cutter as sold by us, with new spout carrier for delivering the feed directly into the elevator without scattering or clogging under the knives. While designed to be used more particularly with the angle carrier, it works equally well with the straight carrier, and machines so equipped are then always in shape for either form of carrier.

The Safety Feed-Roll Lever, seen at the side of the cutter, is used to elevate the upper feed-roll, throwing the same quickly off the feed, so that the amount of feed passing through the rolls can be regulated, and all choking or clogging be prevented. When necessary from accident or otherwise, the feed is stopped instantly by pressing the treadle lever down to the floor. A touch of the foot returns it to its former position, and the work is resumed. This obviates the necessity of throwing the feed-rolls out of gear by the use of hand levers, or of slowing down the power. Being operated instantly by the foot and placed well to the rear of the machine, it is quickly and easily reached, and is attended with less danger to the operator than any device for a like purpose yet constructed. It can be readily detached so as to be used on either side of the machine.

These attachments are furnished as extras, and are provided at reasonable prices.

\section{Horse Hay Forks}

IVe carry in this line all the carefully tested and improved implements of today. Prominent among them you will find the well-known Palmer, Double and Triple Grapple, and Nellis' Harpoon. Call for descriptive circulars.

In our varied stock gou will find

HAY PRESSES, HORSE POWERS, FARIMES'

BCILERS, STONE DRAGS,

ROAD SCRAPERS, TUBULAR IRON BARROWS and other articles not catalogued for want of space

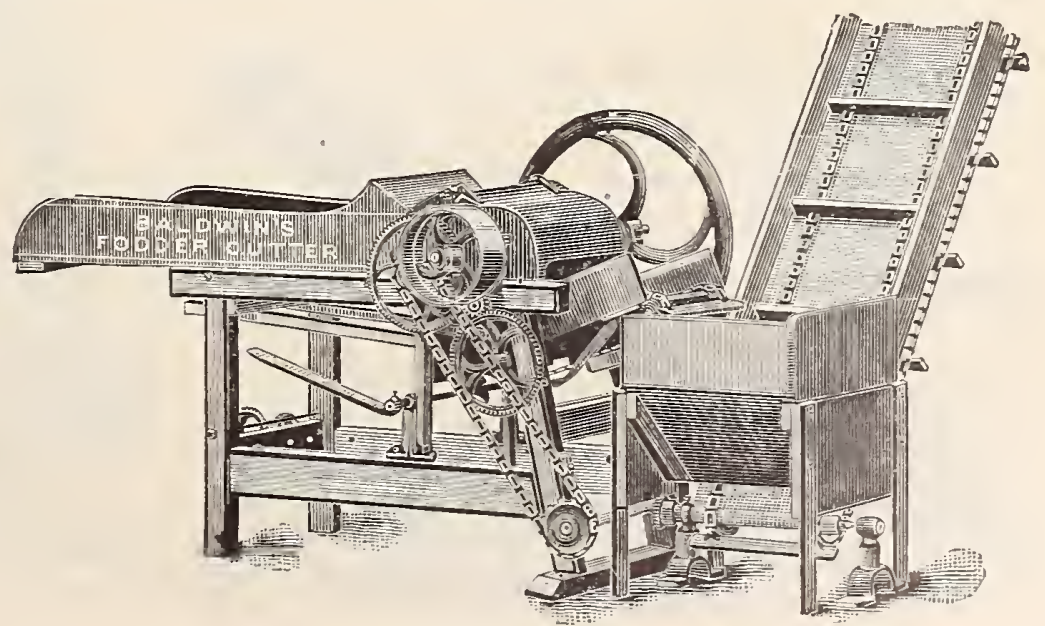




\section{"Planet Jr." Tools for 1907}

Space will not permit our showing and describing all of the "Planet Jr." Tools, but we will send a fully illustrated catalogue free for the asking to any who desire it. "Planet Jr." goods are standard machines; the best ; yet great improvements have been made for igo

\section{"Planet Jr." No. 3 Hill=Dropping Seeder}

Sows either in Hills or in continuous Row

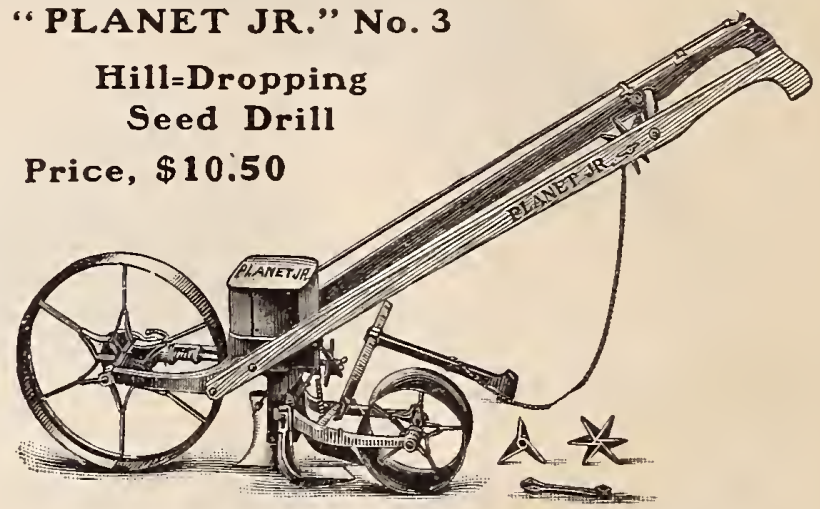

A fine Hill-Dropping Seeder, with hosts of friends, and for 1907 it is greatly improved. This Drill will sow in a continuous row, with the greatest regularity, but its distinctive feature is that it will drop neatly in hills either 4, 6, 8, I2 or 24 inches apart. The wheel is 15 inches high, with a broad face. It is changed in a moment from hill-dropping to drill work, sows equally well whether the hopper is full or contains only a paper of seed, and will not injure delicate seeds which are so often peeled or crushed by imperfect seeders. The plow is adjustable, and opens a very narrow furrow, which is a great advantage for after-cultivation Capacity, 3 quarts.

"Planet Jr." No. 4

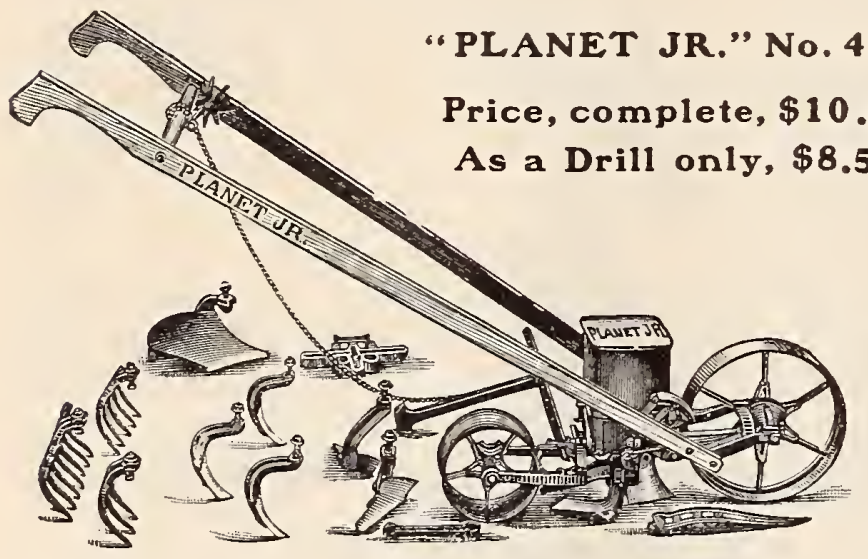

"Planet Jr." No. 25

\section{Combined Drill and Double Wheel=Hoe}

This new combined machine holds $2 \frac{1}{2}$ quarts. As a Drill it is almost identical with the No. 4, and as a Wheel-Hoe is identical with No. I2 Double Wheel-Hoe. The change from Drill to Wheel-Hoe takes but a moment.

The simplicity and perfect working of this tool, both as a seeder and as a Wheel-Hoe, make the combination thoroughly practical. The accuracy of the seeder in sowing all varieties of garden seeds, whether in hills or drills, and the adaptability of the Wheel-Hoe to various kinds of garden and field work make a perfect tool.

"PLANET JR." No. 11

Double Wheel=Hoe,

Cultivator, Rake and Plow

Price, \$9

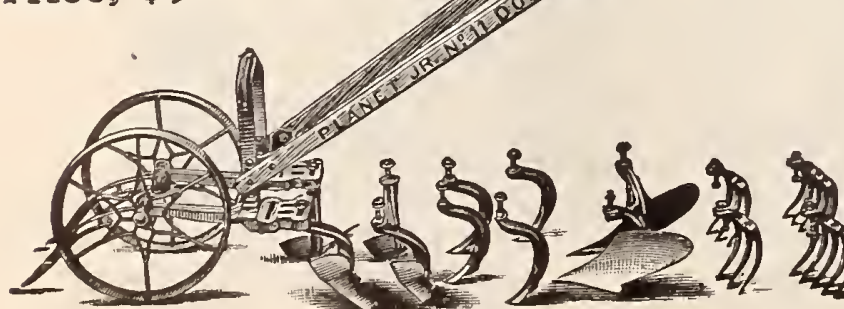

Wheel=Hoe, Cultivator, Rake and Plow

This is exactly the same style of seeder as the No. 5 "Planet Jr." Hil the smallest paper of seed perfectly, and is simple, durable and very is. Throws out of gear instantly by simply raising the handles. is accurate, plain and easily set. The drill is detached and the too frame substituted by moving but one bolt. It then becomes one of the most admirable Single Wheel-Hoes of the "Planet Jr." family.

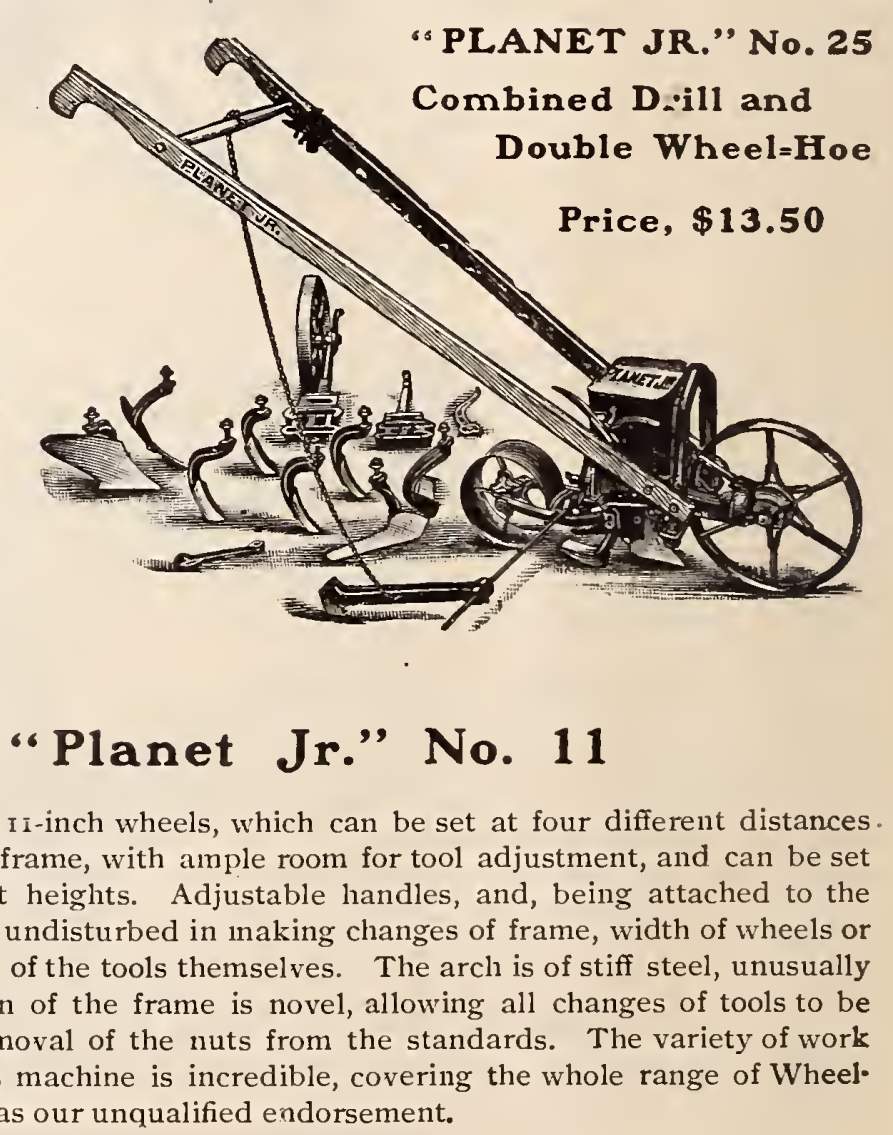

This tool has Ii-inch wheels, which can be set at four different distances apart; malleable frame, with ample room for tool adjustment, and can be set at three different heights. Adjustable handles, and, being attached to the arch, are entirely undisturbed in inaking changes of frame, width of wheels or in the adjustment of the tools themselves. The arch is of stiff steel, unusually high. The design of the frame is novel, allowing all changes of tools to be made without removal of the nuts from the standards. The variety of work possible with this machine is incredible, covering the whole range of WheelHoe work, and has our unqualified endorsement 


\section{"Planet Jr." No. 12}

This tool is identical with No. II, except that it has la less complete equip ment, as shown in the cut, but at a correspondingly less price. The set of tools with No. 12 is what gardeners need most, and the rest can be added as wanted.

\section{The "Planet Jr." No. 13 Double Wheel=Hoe}

This tool is the No. II with 6-inch hoes only. Any or all of the No. II tools may be added at any time, and are sure to fit. Price, \$4.75.

\section{The "Planet Jr." No. 16}

Single Wheel-Hoe, Cultivator, Rake and Plow

This Wheel-Hoe is identical with No. I5, except that it has fewer tools, but the price is proportionately lower. The equipment is a most useful one, and will be found just right for a great variety of work. Price, \$6.85.

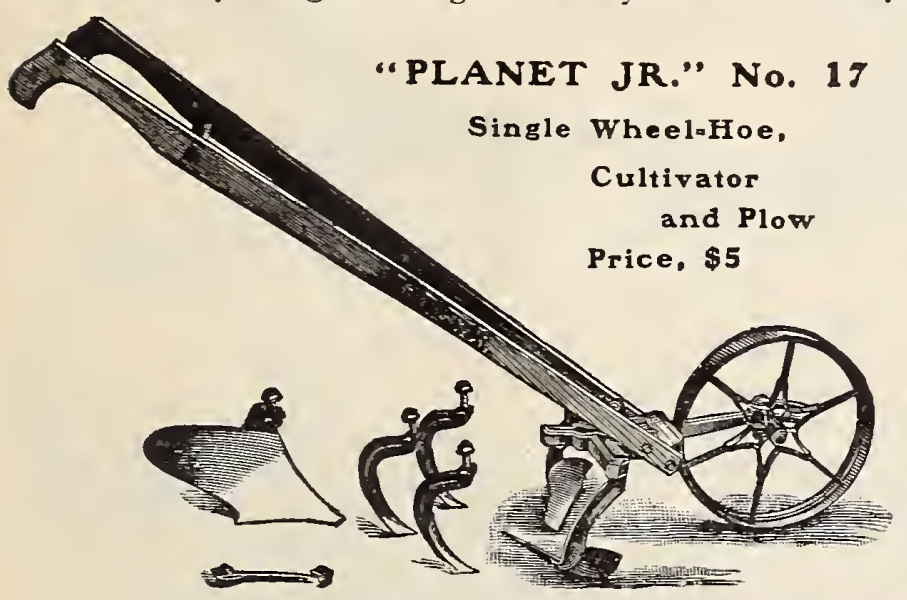

The "Planet Jr." No. 18 Single Wheel-Hoe

With the same frame and handles as No. 15 , but it has I pair of 6 -inch hoes only, but they are the most useful of all the list. Price, \$3.50.

\section{The "Firefly" Plow}

This tool is valuable for those have small gardens. The moldboard is tempered and polished steel. The depth may be changed very quickly. The low price brings it within the reach of all. Very useful to plow up the chicken yard. Price, \$2.35.

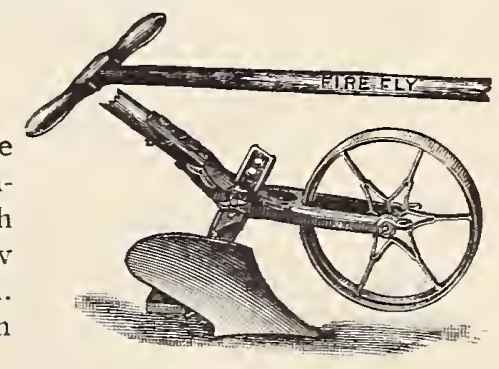

The "Planet Jr." No. 6

Combined Hill and Drill Seeder, Hoe, Cultivator and Plow. Price, \$13.50. "Planet Jr." No. 6 Hill and Drill Seeder. Price, \$11

This latest "Planet Jr." Hill and Drill Seeder and Wheel-Hoe has been under construction for two years past, and has been held back until every detail has been made as nearly perfect as it seems possible to have it. We have sold Hill Seeders for a number of years past and they have been received and used with a great deal of satisfaction. This is easily accounted for, as about one-half of our garden seeds are preferred in hills. Hill seeding can be done just as rapidly as drilling; much seed is saved and the crop is more regular, and uniformity is one of the prime conditions necessary to produce a large yield.
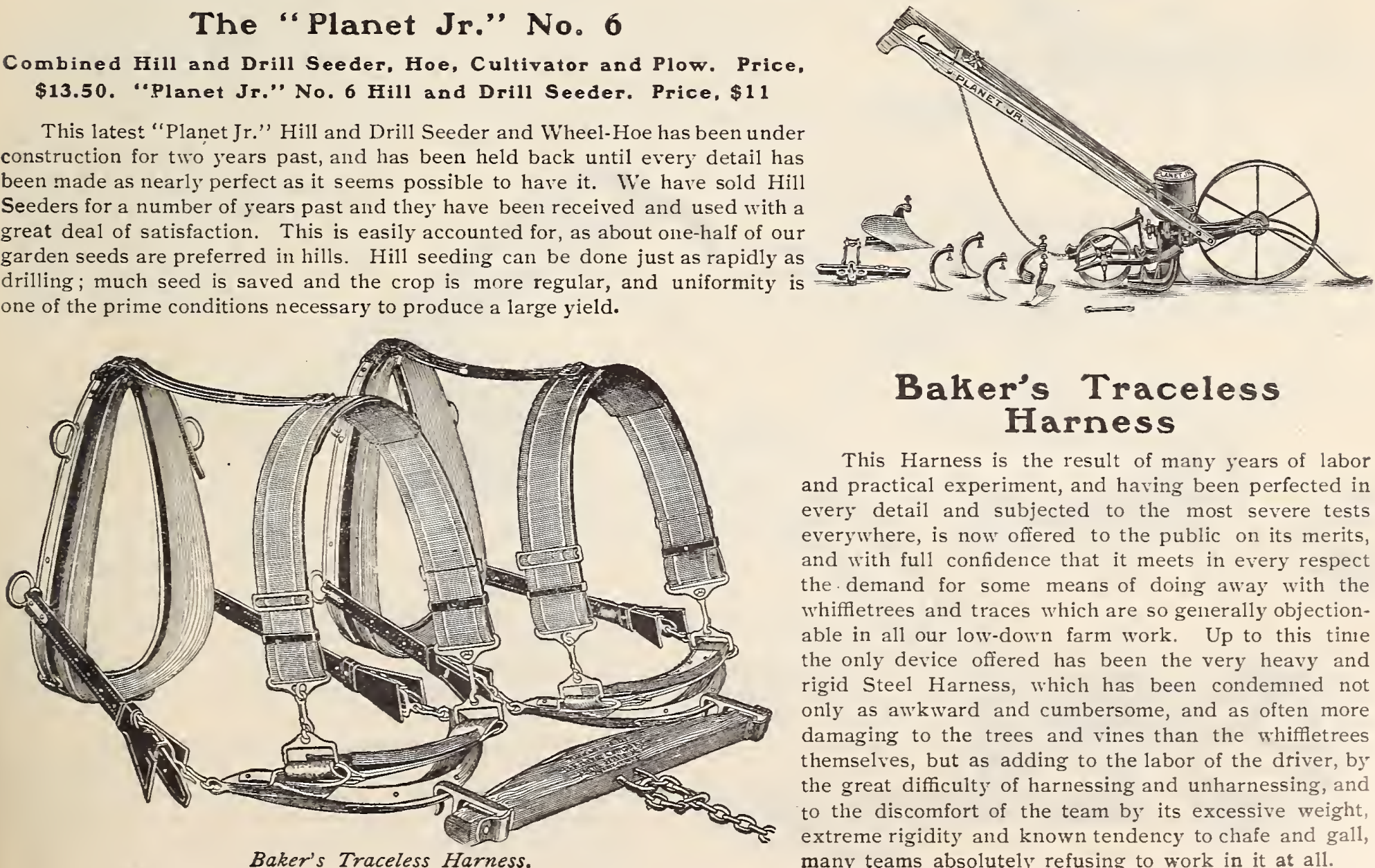

\section{Baker's Traceless Harness}

This Harness is the result of many years of labor and practical experiment, and having been perfected in every detail and subjected to the most severe tests everywhere, is now offered to the public on its merits, and with full confidence that it meets in every respect the demand for some means of doing away with the whiffletrees and traces which are so generally objectionable in all our low-down farm work. Up to this tine the only device offered has been the very heavy and rigid Steel Harness, which has been condemned not only as awkward and cumbersome, and as often more damaging to the trees and vines than the whiffletrees themselves, but as adding to the labor of the driver, by the great difficulty of harnessing and unharnessing, and to the discomfort of the team by its excessive weight, extreme rigidity and known tendency to chafe and gall, many teams absolutely refusing to work in it at all 


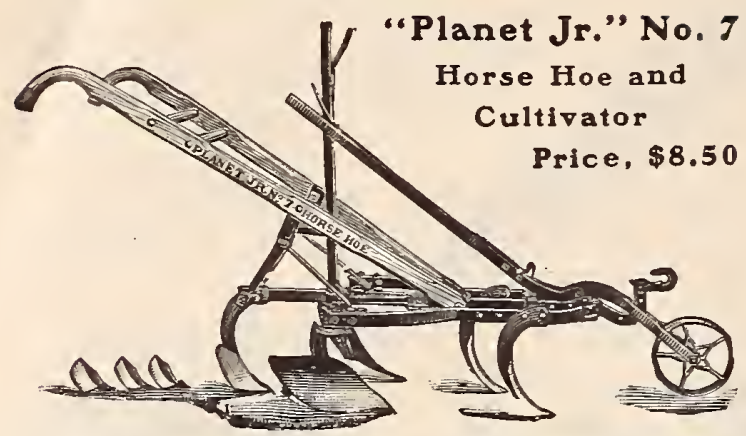

\section{"Planet Jr." No. 7 Horse Hoe}

Probably no other cultivating machine is so widely known as the "Planet Ir." Combined Horse Hoe and Cultivator, for it is in use throughout the civilized world. It is so strongly built as to withstand incredible strain, yet it is light and easy to handle.

The Expander. This is an entirely new pattern, superior to all other forms; exceedingly strong, simple, accurate and positive in all positions.

Handle and Braces. These are also new and the most effective and stiffest combination known, at on making the tool rigid, yet allowing every adjustment of handles in height and siaiewise.

The Reverslble Side Hoes, patented, are an important part of the implement. tool becomes a gentine horse hoe, working so shallow and close, without injury to the roots, that an immense amount of hand labor is avoided.

\section{"Planet Jr." No. 9 Horse Hoe and Cultivator}

No. 9 is identical with No. 7 Horse Hoe, except that it has a bolted star wheel instead of one operated by a convenient lever. The slight difference in price in favor of No. 9 will recommend it to some, though an increasing majority appreciate the great convenience of the lever wheel, and consider that it saves the trifling difference in cost almost every day it is in use. It is always convenient.

\section{"Planet Jr." No. 5 Horse Hoe and Cultivator}

There is still some demand for the No. 5 , which is similar to No. 9. Price, \$7.35.

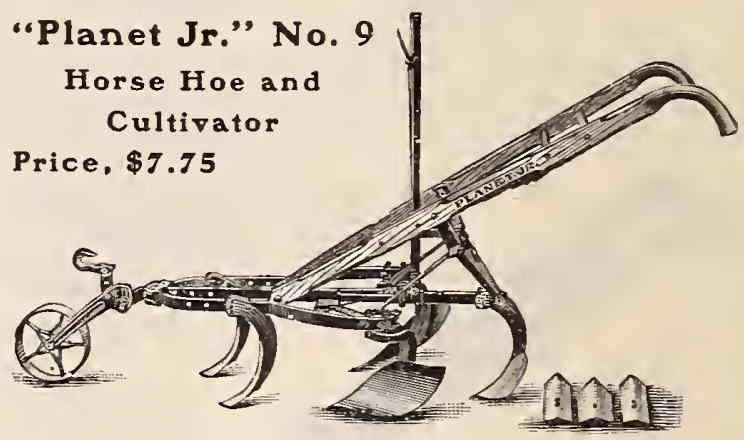

\section{"Planet Jr." Twelve=Tooth Harrow, Cultivator and Pulverizer Price, plain, $\$ 6.20$; with wheel, $\$ 7.40$; complete, $\$ 9$}

This thorough-working and convenient tool has rapidly grown in favor among strawberry-growers, market-gardeners, truckers and

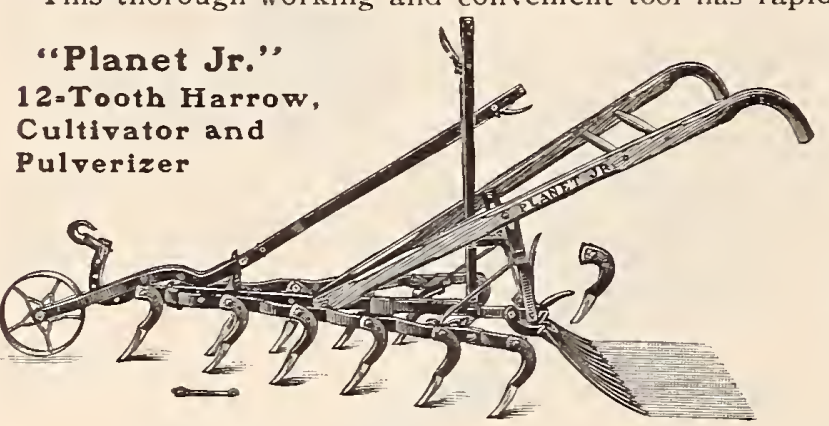
farmers. This is because the twelve chisel-shaped teeth do such thorough work, without throwing earth on small plants, and because the tool is so convenient, durable and strong. It is invaluable in na rrow rows and delicate work in market-gardens.

\section{New England Horse Hoe}

Although introduced to eastern farmers but a few seasons since, this Cultivator has sprung at once into rapid and well-deserved popularity. As shown in the cut below, it consists of a cultivator with two broad hilling wings attached, and a strong iron frame that cannot be injured by exposure to the weather, or liable to breakage in hard soils. When wanted as a cultivator, the hilling wings can instantly be detached and hung on the rod that passes through the handles, by simply remoxing three thumb nuts. Then by lowering the two teeth which have been previously pushed upwards on top of the frame, and fastening them securely in

\section{Eureka Horse Hoe and Cultivator} Combined

WITH THE NEW PATENT ADJUSTING IEVER ATTACHMENT

This is one of the most durable implements of its class on the market. Has steel frame and standards throughout, and tempered crucible steel plates, which combine strength, durability and lightness. The price is lower than that of any other first-class machine.

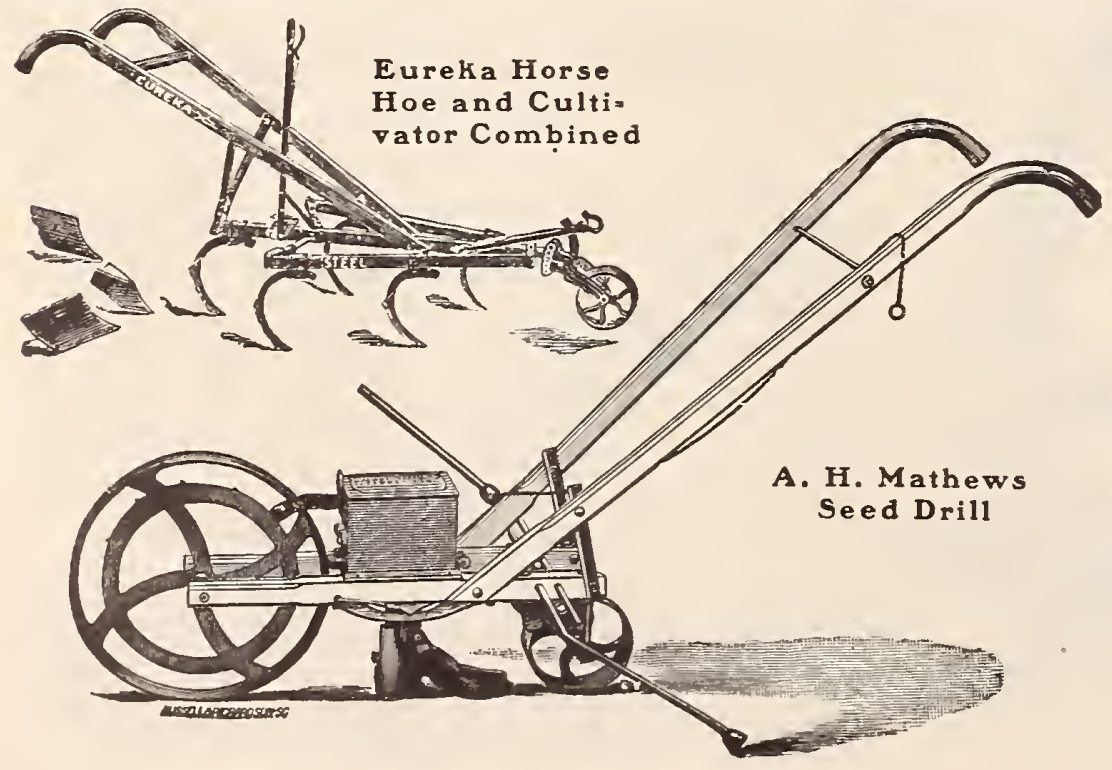
their places, it becomes a good, thorough pulverizing cultivator. By such an arrangement all risks of mislaid parts is entirely avoided. We confidently recommend this implement to all desirous of good, strong, serviceable machine, well adapted for use in all kinds of soil.

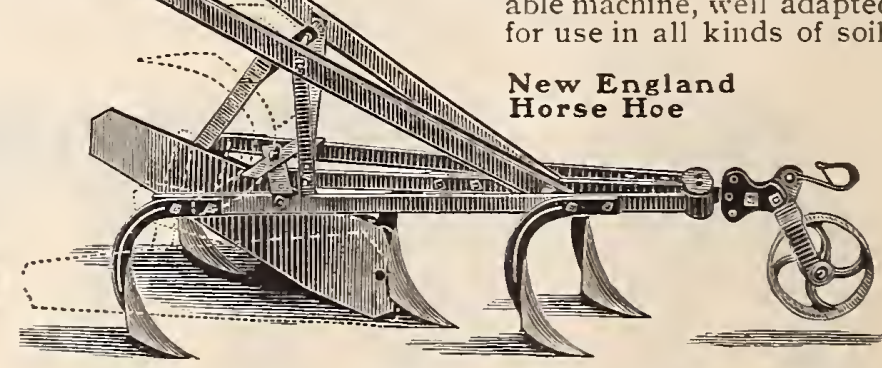

\section{Diamond Tooth Cultivator}

This is the most complete and perfect tool of the kind on the market, combining, as it does, a field cultivator and - uperb garden harrow and pulverizer. It has fourteen $5 / 8 \times 7 / 8$ steel diamond teeth, drawn to a cutting edge on one end. By a very simple device the slant of the teeth can be changed so that the tool can be made a perfect smoothing harrow. It is especially adapted for getting out dog grass.

\section{A. H. Mathews Seed Drill}

For 30 years we sold the A. H. Mathews Drill, and it became known in this vicinity as the "old reliable." Newer designs pushed it one side for six or eight years, but last year we had so many calls for it we decided to have fifty machines made up, which we will have in time for this season's trade. 


\section{The Worcester Buckeye Mower}

The season of 1906 was a memorable one, and marked an era of greater development in the Worcester Buckeye Mower than ever before in its history. This season saw the perfect development of the new Standard Gear Mower, with its new foot-lever, a new tilting device, increased speed, greater strength, and many other improvements. It is generally admitted that the 1906 Mower was the best ever produced.

The 1907 Mower is fully up to the standard of the past in every respect. We give our patrons their choice of a wooden or a steel pitman and leave it to the user to decide which is best. At the crank end of the pitman is a double self-oiling box with a reservoir for oil, woolfilled, which diffuses oil freely. A brass bushing revolves inside of the pitman box, making a double wearing surface.

The ball scythe head is made hollow, with an oil channel opening on both sides for diffusing oil.

We mention here only a few of the new features. An illustrated and descriptive catalogue free to all.

\section{Bullard's Improved Hay Tedder}

This Tedder has a fork outside each wheel; the distance between the wheels is much lessened, and the Tedder much easier handled by a light horse. Also the grass passed over by the wheel is picked up

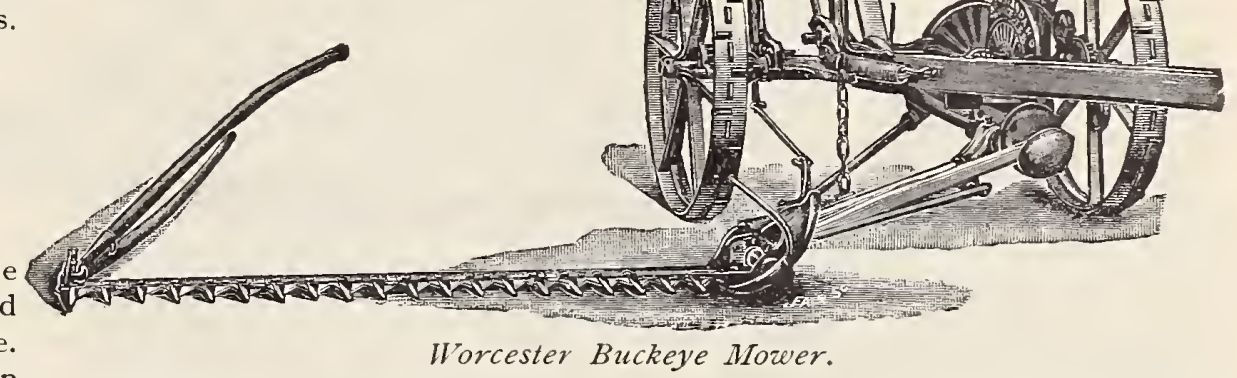

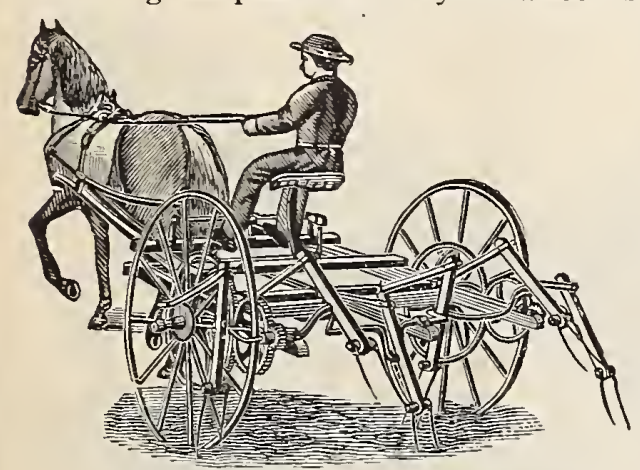

Bullard's Improved Hay Tedder.

and thoroughly shaken, leaving no wheel tracks. This is a patented arrangement, and can be found in no other Tedder.

An excellent arrangement of the hand lever for throwing the Tedder in or out of gear without leaving the seat.

High action, which stirs the grass more, causing it to dry quickly and more evenly.

It is thoroughly constructed, with strong frame and wheels, nicely painted, and has the strongest crank shaft of any in the market. All bearings and boxes nicely fitted. Cranks and all other parts are interchangeable.

Bear in mind that this is the oldest and only Tedder that has proved satisfactory after years of service, and every other Fork Arm Tedder now built is but an imitation. Also, that there are more Bullard Tedders in use than all other Tedders combined.

\section{Steel Tedders}

As there is a demand for a Steel Tedder, we offer this season the Lion All Steel Tedder and the O. R. C. Tedder, which has steel wheels and a wood frame. Both these Tedders have the Coil Relief Spring Fork. These machines are firstclass in every respect. Descriptive circular with full particulars free on application.

\section{Fowler Mower Knife and Tool Grinder}

This Grinder ranks first among all tool sharpeners. It can be adjusted to any position by means of the ball and socket joint, and it puts a perfect bevel or sharp edge on sections, scythes, feed-cutter knives or any other edged tools without extra wheels or appliances. The bar is perfectly free and the bevel of the section or

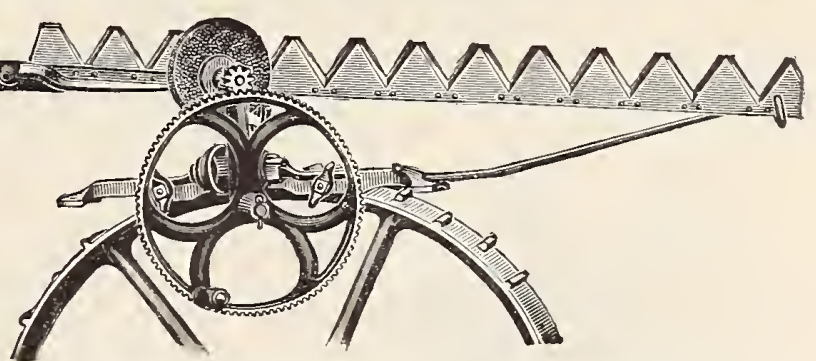

Fowler Mower Knife and Tool Grinder. cutting edge is always in plain view of the operator, and when the Grinder is once adjusted it is not changed until the work is done. It is the only machine made that will grind a broken or nicked section to a serviceable edge, and with it the most difficult and despised job on the farm becomes a pleasure. Sharp mower knives make light, elean work and save wear and tear on machine and team. Upwards of I00,000 of these Grinders are now in use.

\section{Mower, Tedder and Rake Repairs}

In buying a mower, tedder or rake, it is important to know about repairs for the same. When new this will not trouble you much, although an accident is liable to occur at any time; but as your machine begins to wear, and, of course, there are some parts which will naturally wear, then you will want a new part, and when you want it you generally want it quick-you are perhaps right in the middle of haying. This is where you are protected; you don't have to wait, we have what you want right in stock. Also, four expresses a day and telephone connection with the factory. 


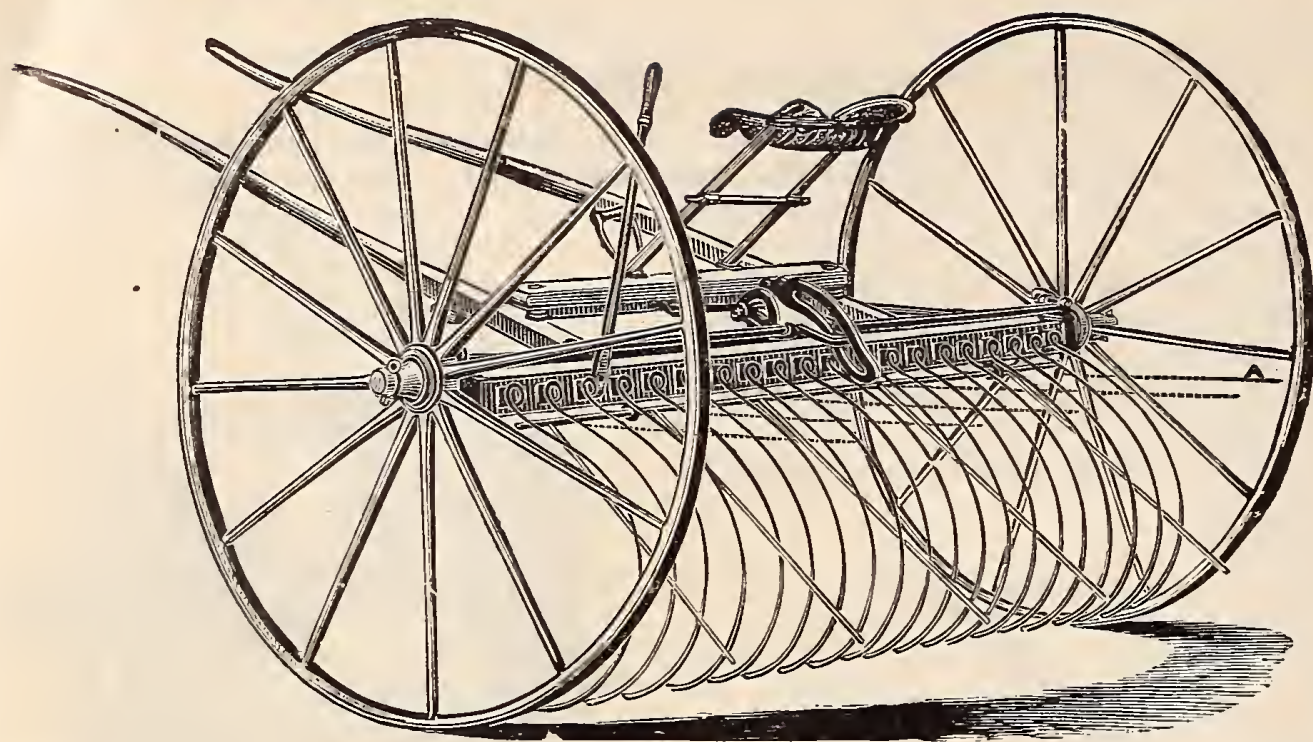

\section{The Champion Rake}

It has a patent tooth to prevent scratching. It has no springs to get out of order. It runs backward as well as forward. It has no Jar on the thills in dumping. Its thills work as freely as those on a carriage. It will not scratch up fine seeding in the harvest field. It will run over trash lying on the ground and leave it there. It can be held down to make very large wind rows, or bunch them up. It is very easy to keep up the teeth after going over a windrow. It packs the windrow, leaving it in good shape for rolling up or pitching. It can take the heaviest grass that grows, as soon as cut.

\section{The Yankee Horse Rake}

Some of the leading polnts of superlor excellence found In the Yankee Horse

Rake: Simplicity of construction and facility of management. Adaptability to any and all conditions of surface and crops. Operated by the power of the horse and the driver's feet. The rake head is hung so as to balance tha teeth. Teeth running level with the ground at their points. Has more teeth (which are hung nearer together) than any other rakes. All the teeth inserted and removed in less than two minutes' time, without disturbing any bolts. Each tooth independent and supplied with a yielding sprin $r$ that will permit the tooth to pass safely over any obstruction that the axle will pass over. Don't buy till you see the "Yankee." Always victorious in every public field trial.

\section{Steel Track Reversible Hay Carrier}

The track is made of Steel T-rails, placed side by side, with space between, large enough to allow hanging hook to pass through. The joints are made alternately, whereby the full strength of one of the rails is retained where the other rail is spliced. The clamp used at the joint has two bolts, which make the track as strong at this point as elsewhere. It is held together entire by a system of clamps. Any ordinary laborer with a monkey-wrench can put it together. The hanging hooks serve also as clamps to hold the track together.

No riveting. It is a complete system, and enables the dealer to supply the farmer with an outfit which can easily be put up. The hanging hooks should never be placed over 4 feet apart, and at point where knocker is placed they should be on every rafter over the load. Always place stop as near under hanging hook as possible. We sell both the Myers and the Ney Carriers.

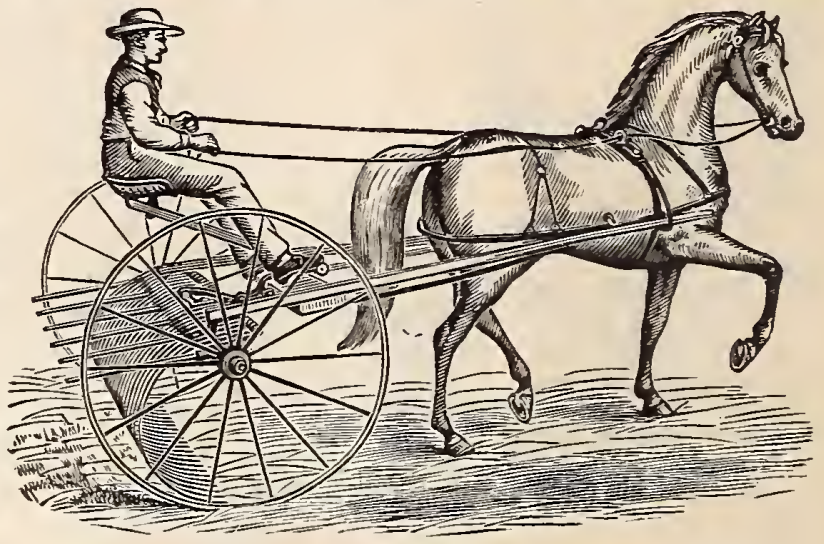

Yankee Horse Rake.

\section{HAND HAY RAKES}

Our stock in this line of goods is the most complete, embracing all the grades of the best makes, including Lawn and Drag Rakes, and our prices will be found very reasonable.

\section{SCYTHES}

Our stock in this department will be found to be one of the largest in New England. We are agents in Rhode Island for the Little Giant, made by the North Wayne Tool Co., also fine Cutlery Steel, Solid Steel, Clipper and Damascus Blade, made by the Dunn Edge Tool Co. These Scythes are guaranteed just as represented. The fact that our sales have doubled in the last few years is good evidence of the quality.

\section{SNATHS}

We shall sell the Now Patent Swing Socket Snaths manufactured by Dery \& Ball (and sold only by us in Rhode Island). Both crooked and straight bend, in cherry and ash, first introduced by us, have become the favorite with most of our trade. We shall have a large stock to offer at low prices.

\section{SHOVELS, FORKS AND HOES}

Our stock of Shovels is the largest to be found in Rhode Island. We carry a full line of $O$. Ames \& Son's manufacture. We are the sole agents for Rhode Island for Bachelor \& Son's, and Ely Hoe and Fork Co.'s Steel goods, manufactured by the American Fork and Hoe Co. Our prices will be found as low as any in the market.

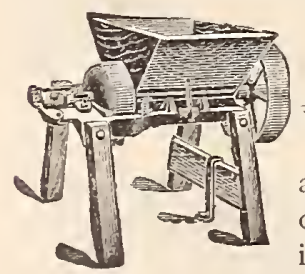

New Holland Feed Mill

The best Mill at the lowest price. Grinds ear corn, shelled corn, rye, oats, etc. Sizes to run by wind power, weep or tread power or engines of small or large size.

The New Holland Mills are cheap only in price. We believe we have the best Feed Mill on the market to-day and are so confident of it that we ask the privilege of sending it out on a iree trial. If you like it, keep it; if you don't, send it back to us, and there'll be no hard feelings. There's our proposition in a nut-shell. One day's test is worth a whole book of talk.

\section{The Farmer's Handy Wagon. What is it?}

The Farmer's Handy Wagon is a low-down, broad-tire, short-turn, extra strong farm wagon with solid wood wheels - or steel wheels if you will have them-put together to stay together indefinitely, eternally or even longer - built to do work and to handle handily everything ever raised or done on a farm. 


\section{THE "BEETLE" FOUR-ROW HORSE-POWER POTATO DUSTER}

While I905 was the first for the Beetle Duster, it being constructed on the same principle as the Champion and Little Giant Dusters that have been in sucli general use for over ten years, the manufacturers did not feel that it was an experiment, and it has indeed proved a success. Four rows of potato vines may be dusted as fast as a horse walks, covering from 20 to 40 acres of potatoes in a day with one horse, according to conditions of land and weather. By the wet process it would require from six to twelve barrels of water and two horses to cover the same acreage, besides double the time; in other words, 50 gallons of water is required for three acres, but only three pounds of Paris Green when applied dry. Can be used for dry Bordeaux, or bug death equally as well. Everything is in favor of the dry process. It saves time, labor and material, and does more thorough work. The dust is blown down through the vines, so as to reach not only the upper part of the foliage, but all parts. The Beetle Duster is always ready for use, and can be operated by an inexperienced person with good results.
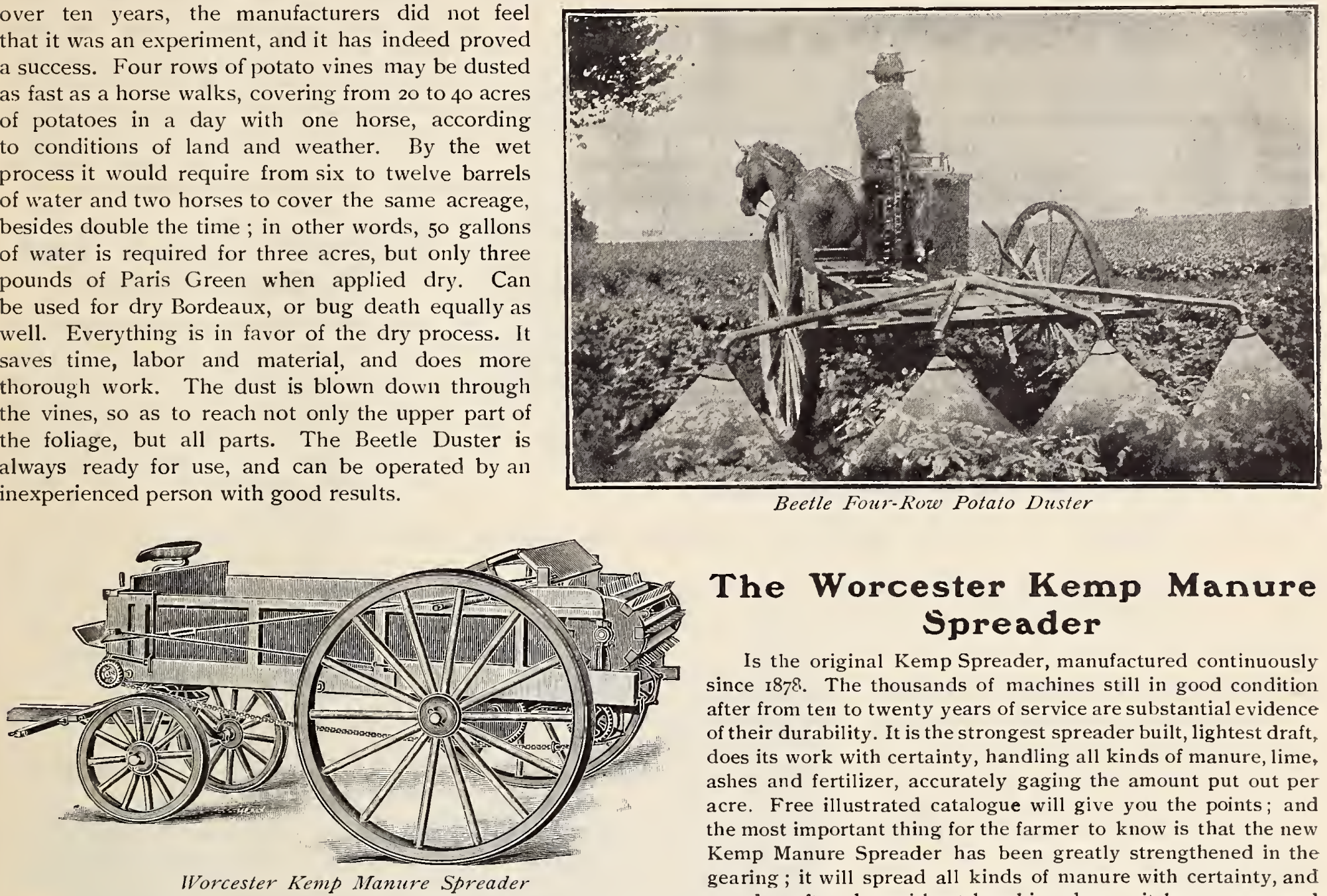

\section{The Worcester Kemp Manure Spreader}

Is the original Kemp Spreader, manufactured continuously since 1878 . The thousands of machines still in good condition after from ten to twenty years of service are substantial evidence of their durability. It is the strongest spreader built, lightest draft, does its work with certainty, handling all kinds of manure, lime, ashes and fertilizer, accurately gaging the amount put out per acre. Free illustrated catalogue will give you the points; and the most important thing for the farmer to know is that the new Kemp Manure Spreader has been greatly strengthened in the gearing; it will spread all kinds of manure with certainty, and run day after day without breaking down; it has a new and patented tail-board which makes a tight box of the body and prevents the manure from banking against the beater and throwing out a quantity of manure when the beater starts; it is the only spreader having two floor chains, and the beater shaft has ball-and-socket bearings, which causes light draft. Built in four sizes.

No. I Spreader, 35-bushel capacity. No. 2 Spreader, 40-bushel capacity. No. 3 Spreader, 5o-bushel capacity. No. 4 Spreader, 7o-bushel capacity.

\section{Thompson's Banner Root Cutter No. 7, for Poultrymen}

Cuts all roots and vegetables in the best possible condition for feeding all kinds of poultry, young lambs, etc. Can be used to good advantage by horsemen feeding carrots, and by small dairymen; turns easily, cuts fast, and is the most efficient little Root Cutter ever made. Choking an impossibility. Feed left in long, small, thin strips. We have no hesitancy whatever in recommending this cutter to poultrymen, because we know it will do the work just as they want the roots prepared for feeding.

\section{Mann's Green Bone Cutter}

You don't know what a Bone Cutter really is until you see Mann's Igo7 model; different from all others, new design, open hopper, enlarged table, new device to control feed.

The Mann's is the machine which cuts hard bones without any more exertion than is required for soft bone. The machine which you can regulate to suit the strength of the operator; the machine which does not clog or stall; the machine which not only cuts bone, but any and all bone, meat and grist!e. Try it for yourself and see. The new catalogue explains all.

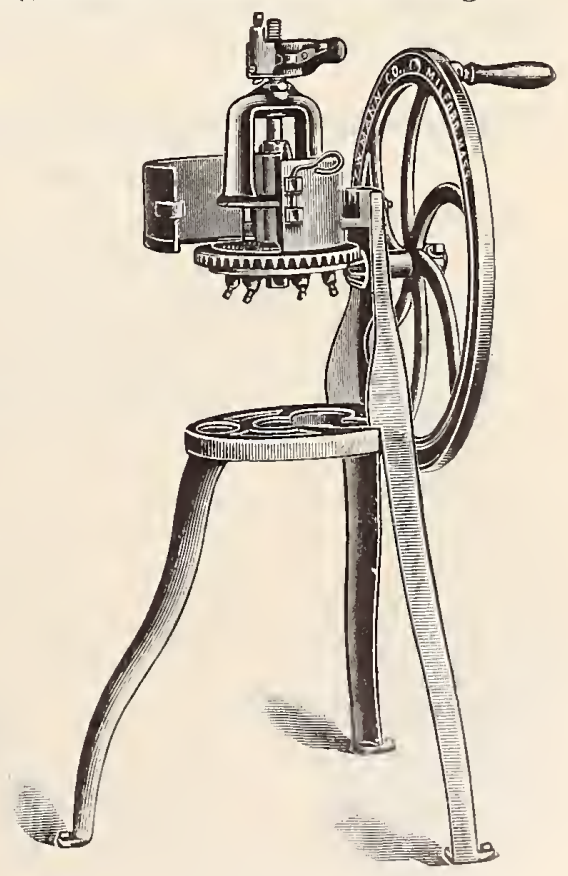

No.7. I907 Model 


\section{AGENCY FOR.THE MERICAN STRELLWOVEN WIRE FENCE \\ Made of Large, Strong Wires, Heavily Galvanized.}

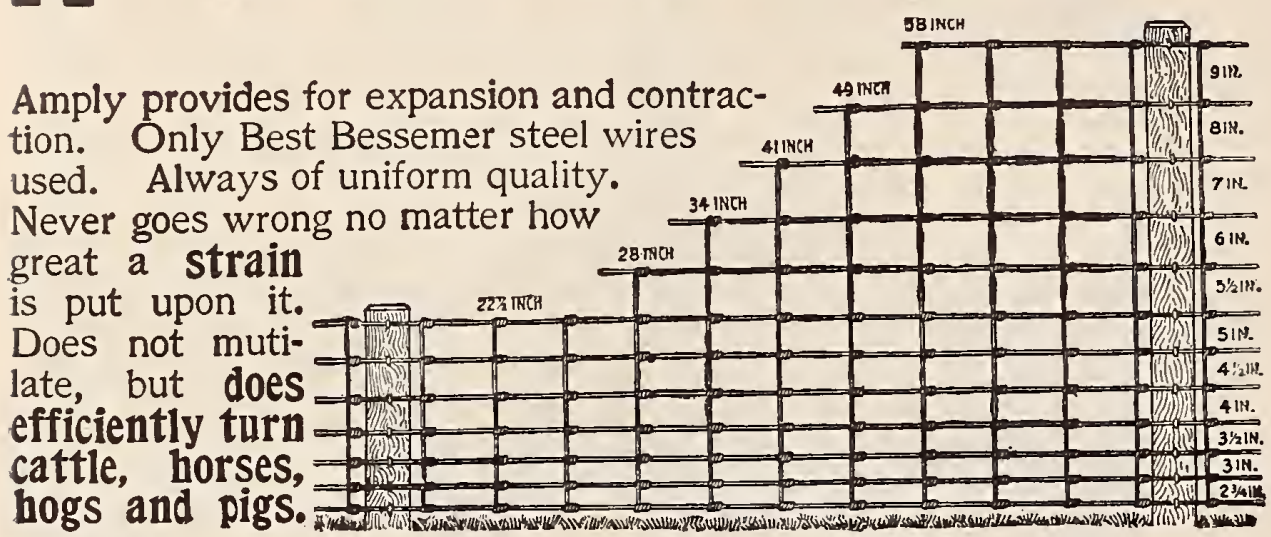

\section{EVERY ROD OF AMERICAN FENCE GUARANTEED BY THE MANUFACTURERS.}

Call and See it. Can show you how it will save you money.

\section{Ellwood Standard Fence}

This fence is made in six heights. The lower heights all have smaller meshes, while the higher patterns have a more open mesh at the top. Small animals seek to break through the lower part of the fence only, and the upper part of the fence with the larger mesh is amply strong for turning the most unruly of the larger animals. Every rod of Ellwood fence is guaranteed.

\section{Ellwood Poultry and Rabbit Fence}

THIS IS A FENCE-NOT A NETTING. A strong and all-important distinction. Twisted coiled cables and single lateral wires, No. I4; cross wires, No. I6. All heights have twisted cable at top. Mesh up to and including 42 -inch height, 2 -inch; above 42 inch height, mesh 4-inch. No need of smaller mesh above 42 -inch height, as poultry or rabbits never go through the upper part of fences, but always attack the bottom. While this style is especially designed as a poultry and rabbit fence, it is sufficiently strong to stop all larger animals. Costs practically the same. as the flimsy nettings, while in the matter of service and durability it is worth ten times as much.

\section{Ellwood Lawn Fence}

The Ellwood Lawn Fence is the outcome to meet the many demands made for a fence at once strong, beautiful and inexpensive, for fencing lawns and yards in towns and villages, for parks, cemeteries and private or public grounds, where beauty as well as utility is required.

The Ellwood Lawn Fence is the strongest possible woven-wire combination, having been tested under most exacting conditions.

\section{Champion Milk Cooler SPECIAL CLAIMS}

It is a perfect aerator, removing all flavors

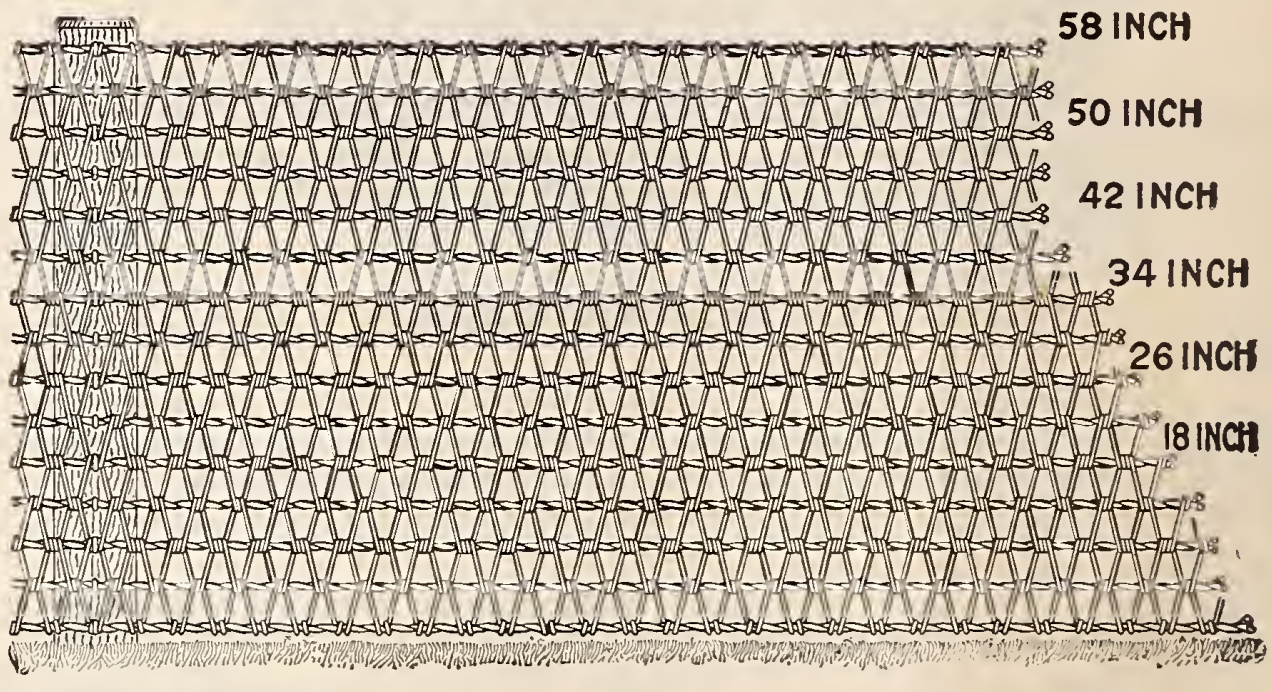
arising from excessive cabbage, turnip or silo rations. It is a complete deodorizer, removing the animal heat or cowy taste and all odors arising from the absorption by the milk of stable or other unpleasant gases. It is a thorough cooler, reducing the temperature of the milk in one minute nearly' to the temperature of the cooling medium.

\begin{tabular}{|c|c|c|c|}
\hline & $\begin{array}{c}\text { Capacity of } \\
\text { Milk Receiver }\end{array}$ & $\begin{array}{l}\text { Size of } \\
\text { Dairy }\end{array}$ & $\begin{array}{c}\text { Takes care } \\
\text { of }\end{array}$ \\
\hline & & I to Io cows & 2 milkers \\
\hline No. 2 & . 18 quarts & 10 to 25 cows & 3 milkers \\
\hline No. 3 & - 34 quarts & 25 to 50 cows & 5 milkers \\
\hline No. 4 & .52 quarts & 50 to 100 cows & 8 milkers \\
\hline
\end{tabular}

\section{Standard Milk Bottle}

STRONGEST, CLEAREST AND IN GREAT DEMAND

For pulp or tin caps. Rounded bottom. Quart, pint and one-half pint Best glass. Most attractive shape; easily cleaned. Prices on application.

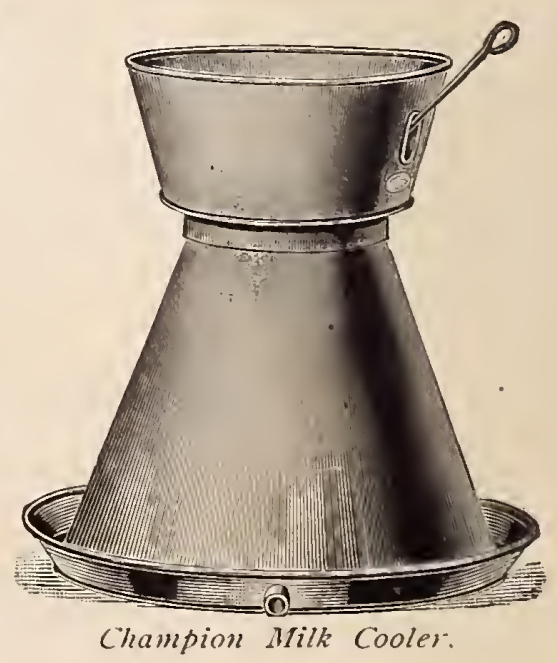




\section{Incubators, Brooders, Etc.}

\section{The Star Incubators}

This line of celebrated machines for 1906 is much improved in the small things that go to make up a complete Incubator, and to lessen the work of the operator. They still contain that same grand old system that has made them famous, but is much simplified, making the running of a Star Incubator simplicity itself.

You know the Star company were the first ones to make it possible to remove the chicks from the incubator without opening the door, you know others have adopted their idea and are now claiming it as their invention. The machines of this year are deeper in the case, allowing for much more packing. They are strictly double-walled machines, with good wool packing between the cases; the first case is built up, then covered with Lone Star Roofing, the outer wall put on, the space between carefully packed. Then, on the top of the radiator is laid a sheet of asbestos paper, then alternate layers of Lone Star roofing and wool, making a most complete packing. Large illustrated catalogue free upon application.

\section{PRICE, WITH CHICK DRAWER}

No. 52. 6o-Egg Regular . . . . . . . . . \$I2 00 No. 54. I25 " " . . . . . . . . . I8 00 No. 56. 250 " " .............. 2800 No. 58. 350 " " . . . . . . . . . 3500

\section{PRICE, FITTED WITH REMOVABLE BOTTOM}

No. 46. 50-Egg Star Special .......... \$7 00 No. 48. 100 " " " . . . . . . . . . . 10 00 No. 50. 200 " " " . . . . . . . . . 2000

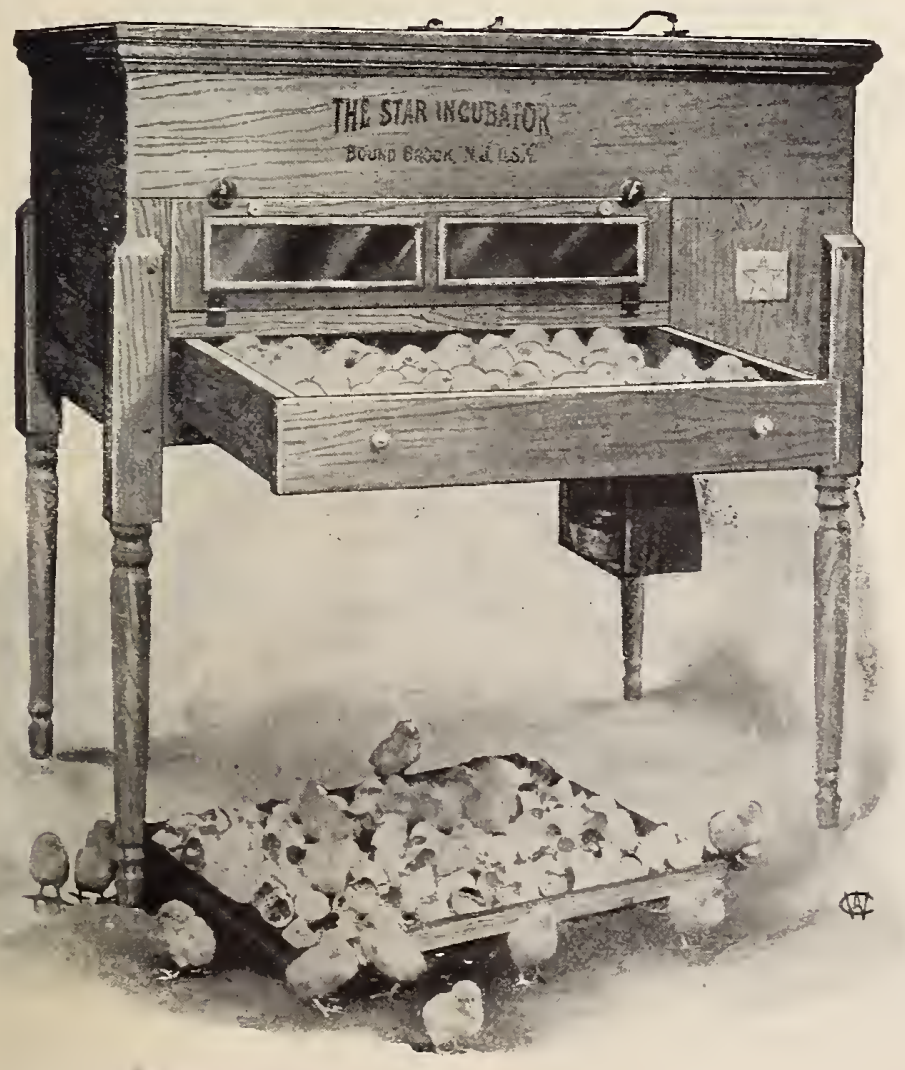

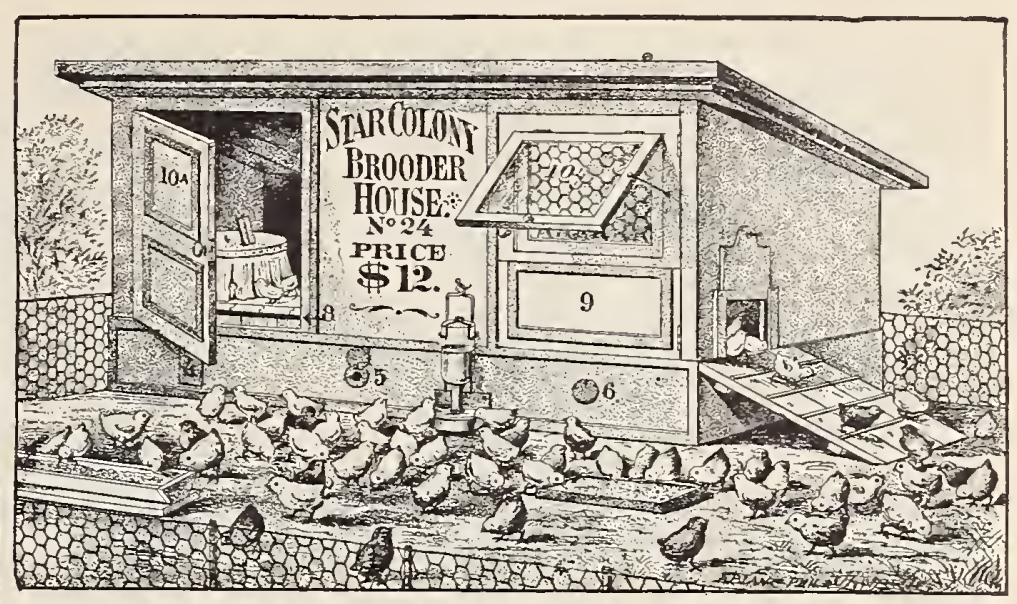

\section{Star Colony Brooders}

This Brooder (No. 24) is 3 feet wide, 6 feet long, 3 feet high in front and 2 feet high in rear. We want you to take special notice of the size and height of this Brooder when comparing it with others on the market.

It is built of the very best lumber and is fully covered with our celebrated Lone Star Roofing, making it absolutely wind and frost-proof. These Brooders are divided into two rooms, one where the hover is, and one for feeding and watering and a place to confine the chicks in bad weather.

We sell this Brooder in three sizes, as follows :

No. 24. 36 inches wide, 72 inches long, 36 inches high in front, 24 inches high in rear. Price, $\$ 12$, with regulator, $\$ 13$.

No. 26. 30 inches wide, 60 inches long, 30 inches high in front, 20 inches high in rear. Price, $\$ 10$, with regulator, $\$$ II.

No. 28. 27 inches wide, 48 inches long, 28 inches high in front, I9 inches high in rear. Price, $\$ 8$, with regulator, $\$ 9$.

We will also carry in stock the two best 5o-chick Brooders on the market-price considered. Outdoor, $\$ 6$; indoor, $\$ 5$.

\section{Star Special Duck Machine Model PJo. 75. Capacity, 200 Eggs}

The new No. 75 special duck machines are now fitted with the new Pile Micrometric Graduating Air Regulator. It consists of a double metal cylinder, one within the other, running from end to end at the back of the egg chamber and terminating with suitable openings on the outside of the machine, and so arranged that ventilation is at all times positively assured. In each cylinder are numerous and suitable openings, the size of which can be quickly changed so as to increase or decrease the ventilation as occasion requires, which is a very important matter in securing good hatches, and in the language of one of the largest successful duck-raisers in the country: "It has no equal and is simply perfection, as a duck machine.

We may say right here that it will hatch chickens equally as well as ducks, and it can be truthfully said that it will give satisfaction everywhere. Price, $\$ 30$. 


\section{Poultry Supplies, Etc.}

Pratt's Food for Morses and Cattle. What is it ? A purely vegetable preparation, containing no mineral or other poison. It is not a medicine nor a condition powder. What it will do: Regulate the bowels, blood and digestive organs, and therefore for horses it will prevent indigestion and loss of appetite. Cows will give richer milk and more of it. Young pigs grow up free from disease, and fatten quickly; their meat will be juicy and tender. Pratt's Food for Horses and Cattle is put up in 12-, 25-, 50and Ioo-pound sacks.

Pratt's Poultry Food. It is an entirely different food from the Horse and Cattle Food. It is put up in 25-cent and 6o-cerit packages, and 12-and 25-pound sacks; is guaranteed to cure and prevent all diseases of the flock, and makes hens lay regularly all seasons of the year.

Rust's Havens' Climax Condition Powders. Contain nothing harmful as a medicine, and are a general preventive for diseases of Fowls, Horses, Cattle, etc. Are very popular.

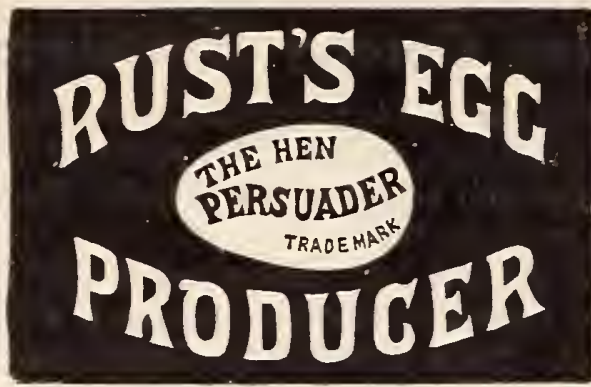

Rust's Egg Producer. Think of it! You can feed Rust's Egg Producer every day for two or three weeks at a cost of one cent for each hen. and get surprising results.

Cut Clover. This supplies a long-felt want in the line of a natural vegetable food; is being used largely this season.

Clover Mea1. Selected clover hay ground very fine for mixing with soft feed. Excellent for laying hens.

Dr. Mess' Poultry Pan-a-ce-a is the scientific compound for poultry. Poultry Pan-a-ce-a cures diseases and makes hens lay. It has special merit peculiar to itself; take no "Poultry Food" or "Poultry Powder" as a substitute. Poultry Pan-a-ce-a is not made from a formula, but from an actual and practical knowledge of every condition and disease that fowls fall heir to.

Dr. Mess' Stock Food. The scientific compound for Horses, Cattle, Hogs and Sheep. This preparation will increase flesh and yields of milk to an extent ausolutely unattainable without it. It is a guaranteed cure for hide-bound, blood disorders, indigestion and all ailments due to an impoverished condition of the system. It should not be considered either as a medicine or a substitute for hay, grain or other feed. It is nutritious and curative It corrects digestion, tones up the system, improves the circulation and supplies the laxative so necessary in keeping the bowels in a healthy condition.

Blatchford's Calf Meal. The perfect milksubstitute for raising calves. One hundred pounds of it makes Ioo gallons of rich, nutritious gruel. Thousands of farmers say Blatchford's Calf Meal builds up calves fast and well at much less expense and trouble than any other milk substitute. Calves can be raised upon it alone without milk at all after they are a few day's old, and this can be done with no other milk substitute.
Used with separator milk or skim-milk it replaces the butter-fats in same, and makes them as nutritious as new milk. Even when whole milk is used, the feeding of Blatchford's Calf Meal with the milk builds up much finer, bigger and sturdier calves in about half the usual time. Blatchford's Calf Meal is also a great preventive of "scouring," and worth its cost for this purpose alone. It contains pure dried milk. It is not oil meal with all the oil out of it, or dried blood, or the by-product of some other manufactured article. Dried blood, for instance, is scarcely adapted for herbivorous animals.

Mann's Crystal Grit. In three sizes. Far superior to oyster shells. Poultry raisers have long desired to secure a sharp clean grit of regular size and superior quality. Crystal Grit is prepared to meet this demand, and has been thoroughly tested.

Sheridan's Condition Powders. Of world-wide reputation. These powders are strictly a medicine, not a food.

Our stock of Beef Scraps, Ground Oyster Shells, Ground Bone and Mixed Feed is always fresh. Wheat, Wheat Screenings, Buckwheat, Barley and Oats, etc., for feeding, always on hand.

Poultry Netting. We have a large stock of the best makes, Clinton and Gilbert and Bennett's, different widths from I to 6 feet, at lowest market prices.

H-O Poultry Food. We claim for the H-O Company's Poultry Food: First, that it is all grain. Second, that it will furnish bone and promote growth in young fowls. Third, that it will insure the highest results in the production of eggs. Fourth, that it will shorten the moulting period; that it is entirely free from all medication and unnatural stimulants, and keeps the fowl in prime condition by the natural means of a properly balanced food.

M-O Scratch. Made from finest grains and granulated almost fine enough for smallest chickens.

M-O Morse Feed keeps horses in good condition, prevents colic, scouring and indigestion.

Animal Meal. This preparation is made from fresh beef and bones specially prepared for an egg-producing food. Fowls fed on this occasionally will be healthy and strong.

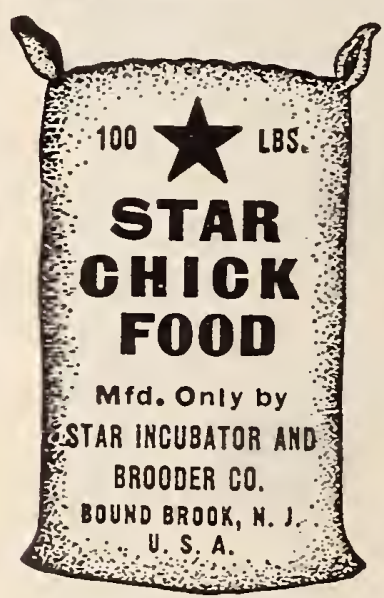

Star Chick Food is scientifically prepared to meet chick requirements. It is not thrown together indiscriminately. The seeds, grain, and other ingredients are carefully proportioned and balanced. Star Chick Food contains the same products nature supplies. All grains and seeds u sed are carefully selected.

Star Dry IIash. The proper proportions are, what we are offering to you in Star Dry Mash for laying hens. Explicit instructions accompany each bag, but right here we wish to say, you should mix it with an equal part of bran. So you see when you buy a bag of this feed you reduce your feed bill very much by mixing a lot of bran with the mash.

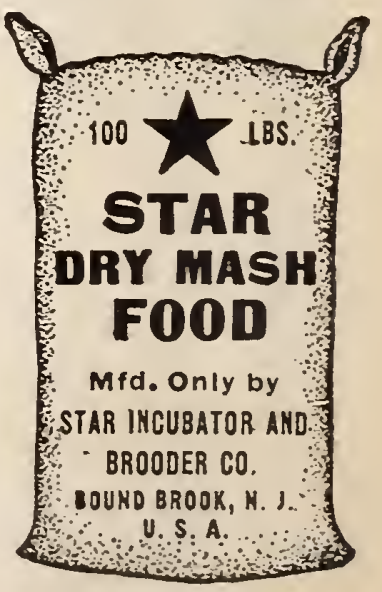

Poultrymen buying in large quantities could save money by looking us over. Get our Prices, We are the largest dealers in Poultry Supplies in Rhode Island. 


\section{DARLING'S FERTILIZERS}

Darling's Anlmal Fertllizer. Contains a very large percentage of ammonia, phosphoric acid and potash. As a general fertilizer for all crops, it is the best. We have sold it fur 30 years, and the increased demand each year speaks volumes for its value.

Potato and Roct Crop Manure. This is one of the best fertilizers for potatoes ever sold. It contains a very high percentage of potash and phosphoric acid, and produces a smooth, desirable-shaped potato. The potash in this brand is entirely from sulphate of potash; the phusphoric acid is from bone.

Farm Favorite. The highest grade low price fertilizer on the market. For all crops above ground will give good results.

Darling's Pure FIne Bone. Contains from 25 to 28 per cent of pure phosphoric acid, and 3 to 4 per cent ammonia. Is the very best material from which phosphoric acid can be obtained.

Darllng's Lawn Dressing. There is a call at the present time for a commercial fertilizer to be used on the lawn. Stable manure is objectionable, as it is bulky, containing a large amount of refuse material. It also contains the seeds of many weeds and obnoxious grisses that are difficult to root out when once they have gained a foothold. By the use of this fertilizer all these objections are removed. It will produce an excellent growth of rich green grass.

Canada Unleached Hardwood Ashos. As a fertilizer for lawns and gardens, Hardwood Ashes are unequaled; they supply natural plant-food, permanently enriching the soil. One of the best for lawns, giving the grass a rich, dark shade of green, and destroying many of the insects which are so injurious to grass, roots and leaves.

Bowker's Ammonlated Food for Flowers. Made expressly for flowers grown in the house or garden; clean, odorless and produces early, abundant blossoms, greatly adding to the richness and brilliancy of color, health and luxuriant foliage. It is clean and absolutely odorless.

Pulverized Sheop Manure. A soluble plant-food, highly recommended for all purposes where a first-class fertilizer is required. It is a pure natural manure, and has long been recognized as one

of the most beneficial. As a top-dressing for lawns it is unequaled. being free from weed seeds and exceedingly stimulating. For lawns, it should be used at the rate of 500 pounds per acre. As a fertilizing agent for plants indoors, and in the open garden, it is one of the very best.

Land Plaster, or Gypsum. This is an excellent addition to land for such crops as require lime and sulphates, particularly turnips, potatoes, grasses, etc.

Sulphate of Ammonia, Dissolved Bone-black, German Potash Salts, Sulphate of Potash, Nitrate of Soda, Plain Dissolved Bone, Muriate of Potash, Sulphate of Potash (High Grade). IVe can furnish these materials, either separate or mived, in any proportion, or to conform to any formula.

\section{Bradley's Complete Manure for Top=Dressing Grass and Grain}

This fertilizer contains a very large amount of nitrogen in quickly available form, besides the right proportions of available phosphoric acid and potash, and therefore imparts to grass and grain, when applied as a top-dressing in the early spring, a quick, vigorous start, and insures early maturity.

\section{Bradley's XL Super= phosphate}

A high-grade complete fertilizer for general usc on all farm and garden crops, either with or without barnyard manure.

From its unvarying quality and uniform condition it has gained the name, "the Otd Reliable," that more plainly than volumes of praise bespeaks the estimate in which it is held among the farmers.

\section{Bradley's Complete Manure with 10\% Potash}

This brand has been placed upon the market for the use of farmers who may prefer more potash for any special crop or soil. This nanure is well balanced, the amounts of the other plant-foods not being sacrificed for the sake of the potash. It is, therefore, better than any other brand adapted to the use of those who believe in large amounts of this ingredient.

\section{Eureka Fly=Killer READ EVERY WORD OF THIS CAREFULLY}

To keep thies off cattle and horses, spray thoroughly once a day. When the flies are very troublesome, twice a day will be

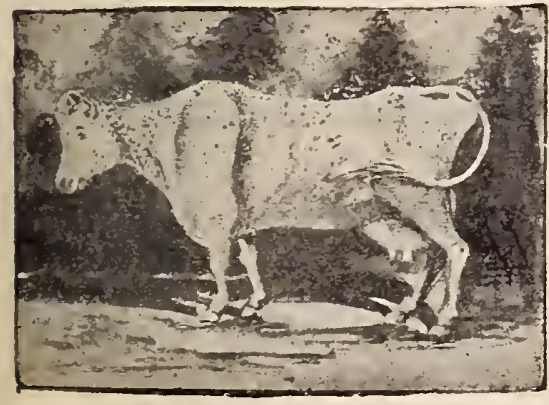

BEFORE USING

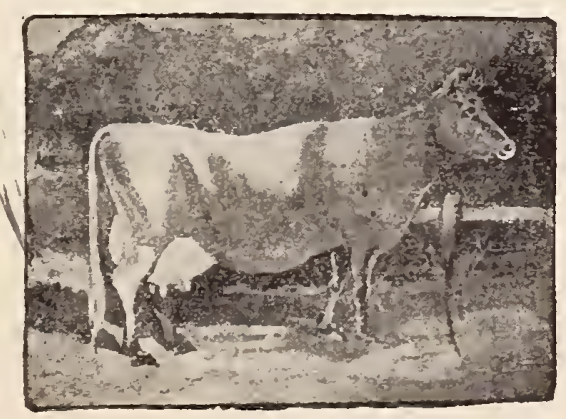

AFTER USING found more satisfactory. The Acme Sprayer is admirably adapted for this purpose. It is absolutely necessary that the leather on the spraver plunger be kept well oiled and the sprayer in condition to throu' a liberal spiay.

\section{FOR LICE ON CATTLE}

Spray thoroughly and card the animal, to work the Killer into the hair.

\section{FOR HOG LICE}

A good liberal application is all that is required. 


\title{
Insecticides
}

Intelligent farmers and gardeners now fully recognize the great helpfulness of Insecticides in fighting the enemies which are so destructive to all sorts of crops. Such remedies are all the more effective if applied early, before the insects, etc., have greatly increased.

Fir-Tree Oil. Destroys insects without injuring the plants. Dilute in the proportion of I pint to 20 gallons of water.

Hellebore, White, Powdered. An excellent protection from currant worms, grape slugs, etc. May be applied dry by clusting on with a bellows, or as a liquid, mixed at the rate of I pound to 30 gallons of water.

Paris Green, Pure. Mixed at the rate of I pound to Ioo gallons of water, it will prove effective against all chewing insects.

Little's Antipest. A sure destroyer of all insect pests. It is non-poisonous and harmless to vegetation. Mixed with water in the following proportions, it is effectual against pests : greenfly, I pint to Io gallons of water; mealy bug, I pint to $1 \frac{1}{2}$ gallons; red spider, I pint to 2 gallons; ants, wire-worms and slugs, I pint to I gallon.

\begin{tabular}{|c|}
\hline $\begin{array}{l}\text { "APMIA BRANd:- } \\
\text { Tobacco-Whale Oil } \\
\text { Soap. } \\
\text { wé kyow ITS Goodings }\end{array}$ \\
\hline
\end{tabular}

slug Shot, Hammond's. Excellent for destroying cabbage, turnip and beet flies, potato bugs, currant worms, etc.

Tobacco Whale-Oil Soap. Effective for scale, green and black flies, mealy bug and red spider in greenhouses, hen lice, dog fleas.

Tobacco Dust. If dusted on while the foliage is moist it destroys rose lice, cabbage and turnip fleas, etc. Spread upon the ground, it keeps off all earth insects, and is an excellent fertilizer.

Tobacco Stems. For fumigating plants infested with greenfly, etc.

Nikoteen Aphis Punk. A preparation of Nicotine in most convenient form for killing insect life on plants and flowers, without injuring the most sensitive bloom or foliage.

Leggett's Fungiroid. A powdered Bordeaux Mixture. Is applied when the foliage is wet with rain or dew.
Whale-Oll Soap. For washing trees and destroying all insects on the bark. Mixed at the rate of I pound to + gallons of water, it will rid cabbage, rose bushes, peach trees, etc., of the aphides that so often infest them.

Sheop Dip. For sheep, horses and cattle.

Bordeaux Mixture. For all fungoid diseases, such as mildew and the various rots of the grape. It is prepared as follows: Dissolve 6 pounds sulphite of copper (blue vitriol) in 6 gallons of hot water; in another vessel shake 4 pounds of fresh lime in 6 gallons of cold water. When both are cool, pour the two mixtures together and add Io gallons of water. This, then, when all is thorouglily mixed, is ready for use, and may be applied at any time without injury to the foliage. We can furnish this all mixed at the small cost of 2 cents per gallon.

Arsenate of Lead. The latest and best-known insecticide for all leaf-eating insects. It adheres to the foliage for weeks, thus making frequent spraying unnecessary.

Morrill's Canker-Worm Exterminator. One of the best and cheapest remedies for the protection of trees from the ravages of the grub or canker-worm. Directions with each can.

Kerosene Emulsion, Concentrated (Lion Brand). One of the best all-around insecticides. Especially valuable for the destruction of the green and the black fly, scale, wooly aphis, curculio and all sucking insects.

Bordeaux Mixture with Paris Green. A combination which, in addition to preventing blight, mildew, etc., will kill potato bugs and all leaf-eating insects.

Flowers of Sulphur. Prevents mildew on grape-vines, etc.

Grape Dust. For destroying mildew on grape-vines and trees ffected with mould, mildew, or rust-mites.

\section{Target Brand Scale Destroyer}

\author{
The Peer of Soluble Oils for the \\ SAN JOSE SCALE
}

This product is a soluble oil which mixes instantly in water and should be applied when trees are in a dormant state.

Directions:- Mix one gallon with twenty gallons of water and apply with an ordinary spray pump.

\section{Prices}

Qt. 35 cts., I/2gal. 65 cts., gal. SI, 5 gals. $\$ 3.75$, Io gals. $\$ 7.50,50$ gals. (bbl.) $\$ 25$.

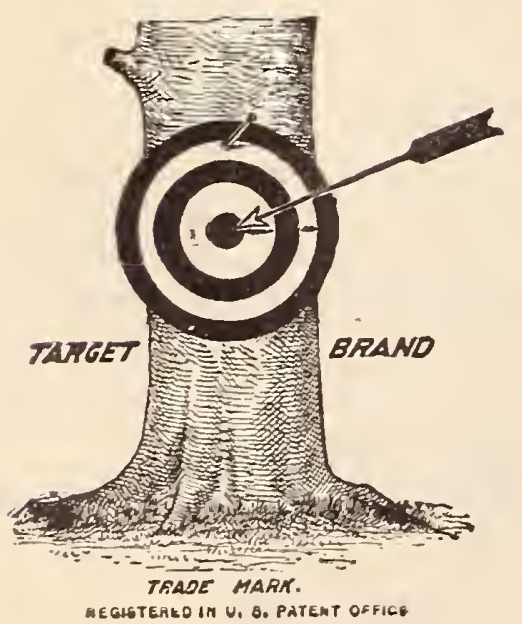

MEGLETEALO IM U. B. PATENT OEFICE

\section{Target Brand Weed Killer}

The greatest and best preparation on the market for killing weeds, grass, and other undesirable plants in roads. paths, etc. Most economical, and results are guaranteed.

Directoos:--Mix one gallon with fifty gallons of water and apply in an ordinary sprinkler.

\section{Prices}

Qt. 40 cts. 1/2gal. 65 cts., gal. si, 5 gals. $\$ 4,10$ gals. $\$ 7.50,25$ gals. (1/2bbl.) \$1 $8.75,50$ gals. (bbl.) \$35. 


\section{“EDELWEISS" REAL PORCELAIN= LINED REFRIGERATORS}

We wish to call special attention to our real Porcelain-lined Refrigerators. We do not mean by this that it is white enamel paint on galvanized iron, but real porcelain on lieavy sheet steel. The porcelain is fused onto the steel at a temperature of $2500^{\circ} \mathrm{Fal}$ renheit, and is proof ayainst corrosion by grease or acid. It is much better than crockery tiles, which are sure to craze, or opal glass which is easily broken. Another objection to tile lining is the fact that it is made up with many joints which will soon be filled with impurities.

Not only is the entire provision chamber lined with real porcelain, but the shelves are also made of the same material. Case of oak, front panels of quarter-sawed oak, heavy round corners, nickel-plated locks and hinges; nine walls.

\section{THE GREAT GLACIER REFRIGERATOR}

We are the Rhode Island agents for the GLACIER Refrigerators, and our experience in selling them the last six seasons etrables us to say, without hesi-

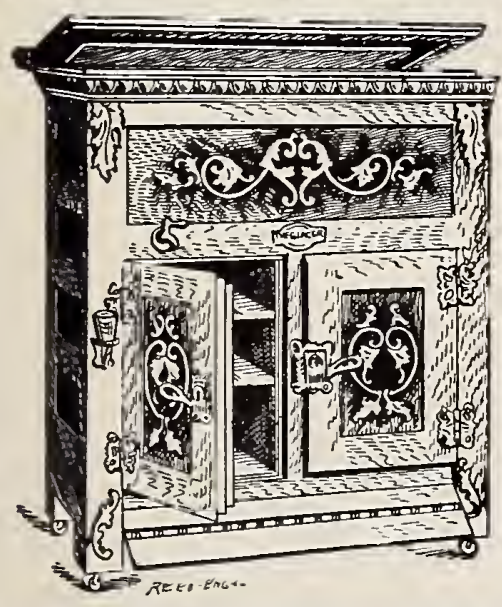
tation, that they are the best Refrigerators o I the market today, price and construction considered, as hundreds can say who have bought them.

If you want a first-class Refrigerator in every respect, we have it in the GLACIER, all sizes and styles, and invite your inspection.

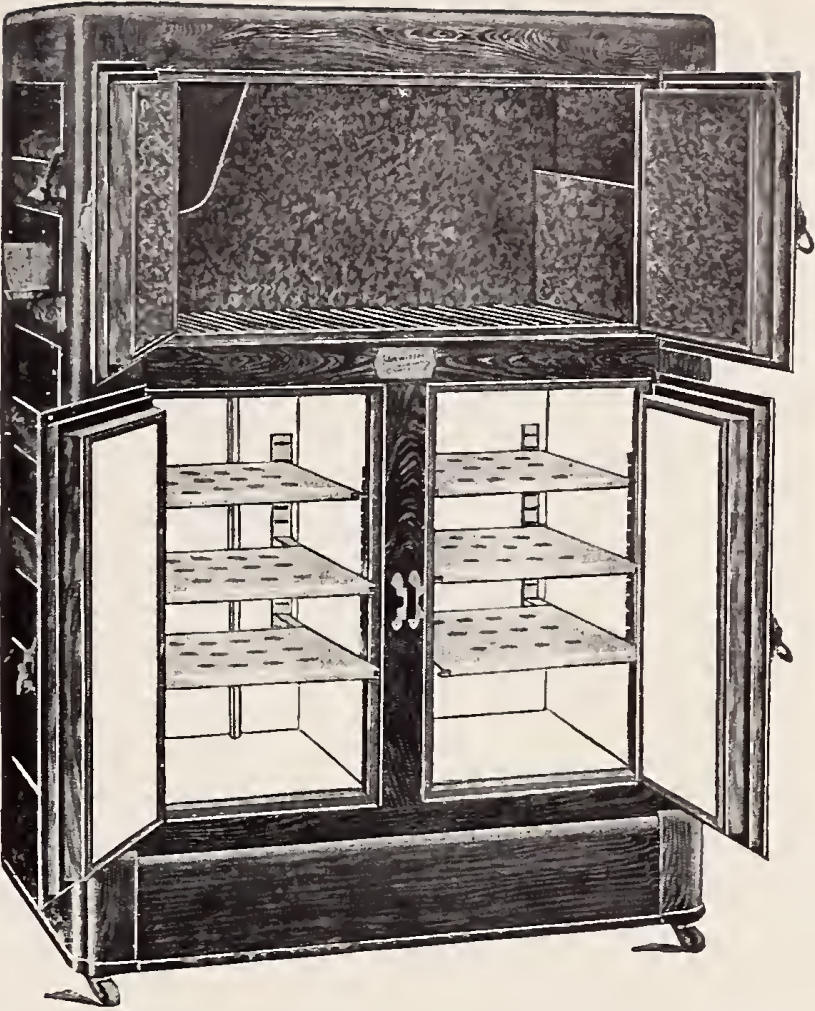

It is made on the cold dry air system, and is the result of the highest order of scientific skill and ingenuity. It prevents the ice from melting rapidly, soon saving its cost in ice bills. It is conveniently arranger and has eight walls. Made of solid ash and is beautifully finished.

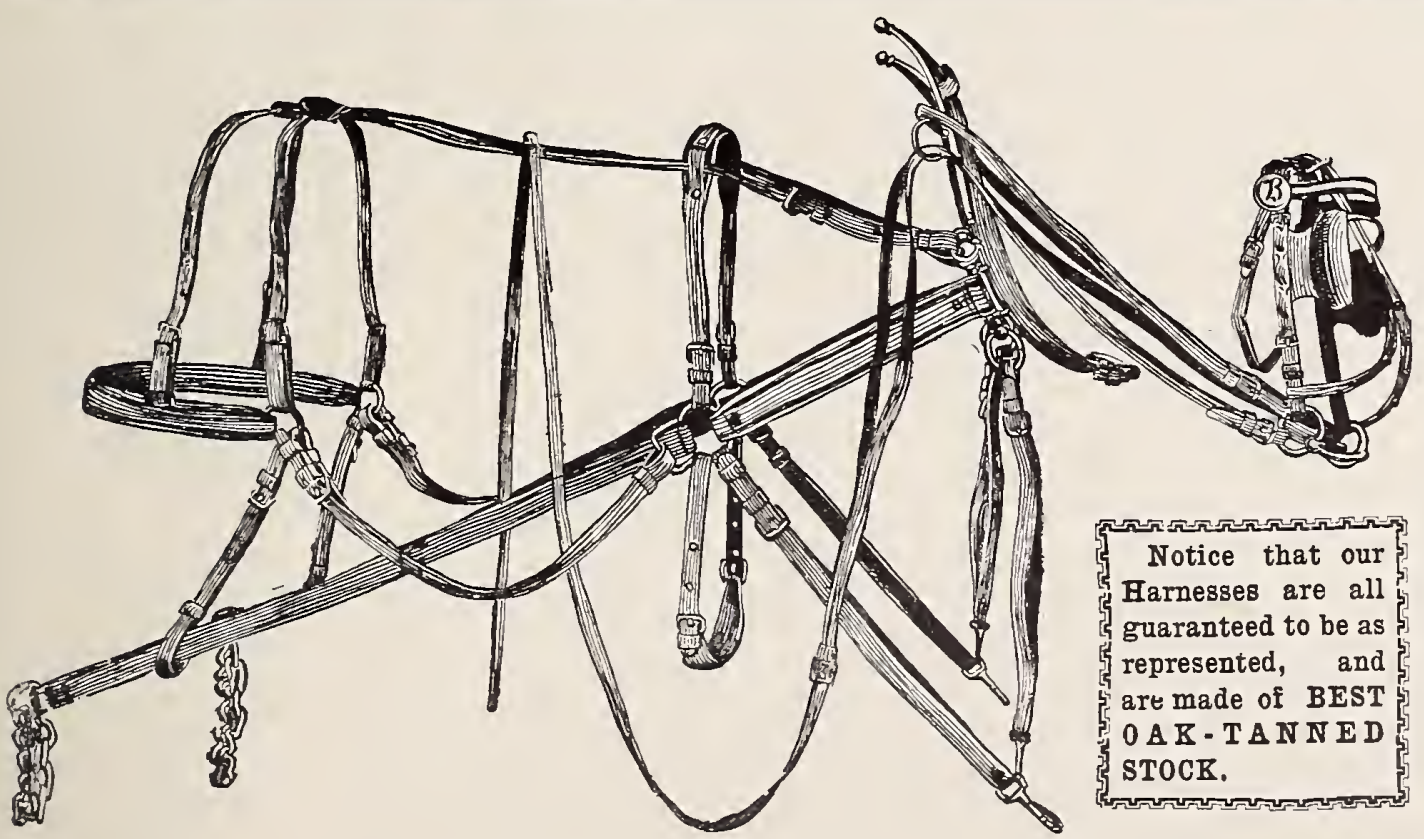

\section{HARNESSES}

If you should buy a Farm Wagon, Horse Cart, Manure Spreader, or any like article of us, what would be more natural than that you should ask us, "Do you sell Harnesses?" We would answer, that for this very reason we carry in stock, at all times, a line of Marnesses adapted for farm and general work, also express and buggy Marnesses in many styles. All of these are guaranteed to be as represented, and are made of best oaktanned stock.

In this department will also be found a full line of Collars, Halters, Mitch Ropes, Feed Bags, etc.

\section{STREET AND STABLE BLANKETS}

This season we have added to our Harness Department a full line of Riley's Celebrated Street and Stable Biankets. This manufacturer's line of goods is known to be first-class in every detail. IVe buy in such quantity as to be in a position to sell at a reasonable price.

\section{Ghe W. E. Barrett Company PROVIDENCE, R. I.}




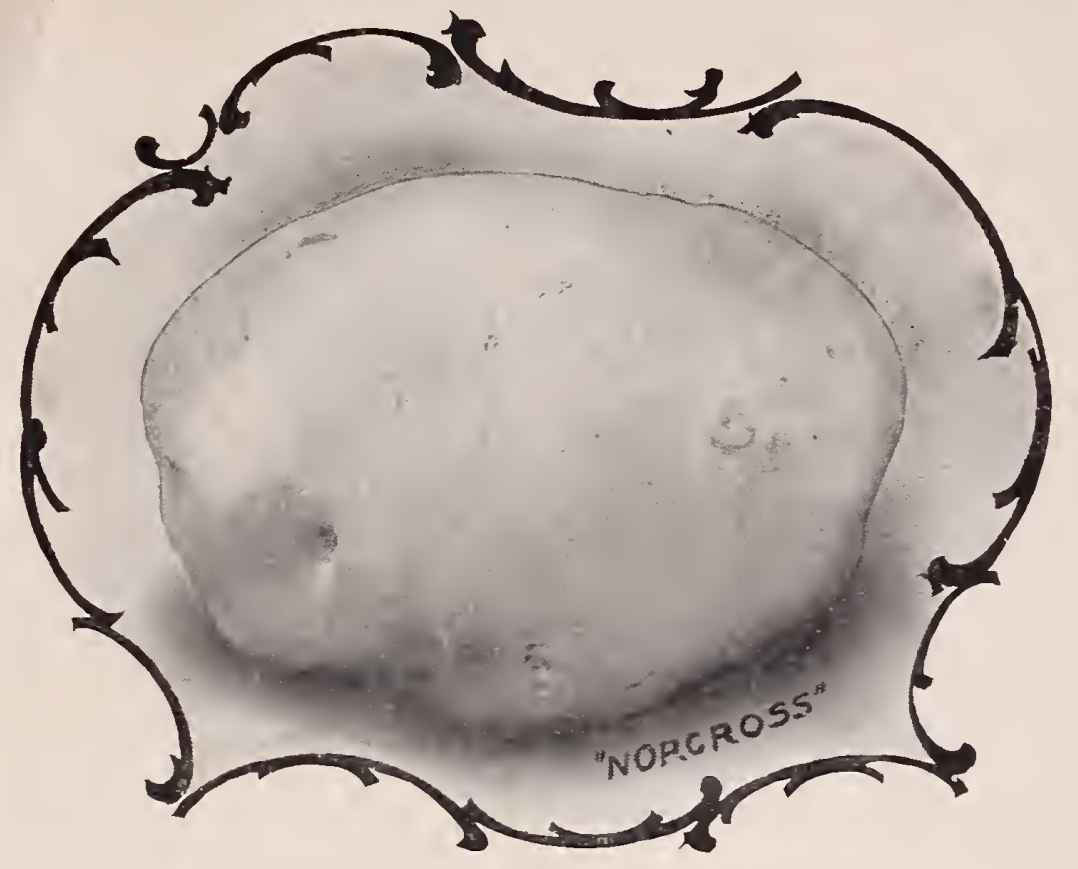

\section{NORCROSS}

Originated by Charles Norcross, Litchfield, Maine. Seed boll grown on the old "Early Rose." pollenized by "Beauty of Hebron." Tested with some 200 other kinds, it was best in quality and yield.

It has been a prize-winner everywhere, and is sure to become the standard maincrop potato. This potato gives you earliness, immense yield, and cooks, when freshly dug, equal to any old potato.

\section{Seed Potatoes and Potatoes for Seed}

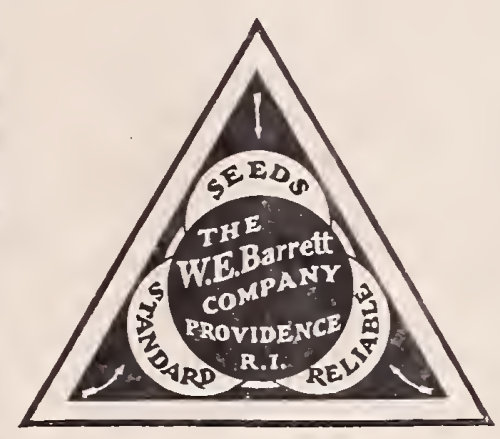

While potato-growing has assumed large proportions, there is still the certainty that a decided increase, if properly conducted, will bring increased profits. To accomplish this, more attention must be paid to the seed and thorough spraying must continue throughout the season. Rust and rot are as controllable as insect pests, but the agents used must be free from Paris green or arsenic. More than sound potatoes is in the balance. The seed stock must be not only sound, but perfect in elementary constituents. Our seed stock is grown with this end in view.

\section{SNOW}

This is a roundish, white potato of extra table quality. The eyes are shallow; the yield immense-300 to 500 bushels per acre. It is medium late and just the potato for this market.

This potato should have been named the "Poor Man's Friend," for it will do the best of any potato on poor soil, or where no care is taken of it. If given good care and fertilization the results are wonderful.

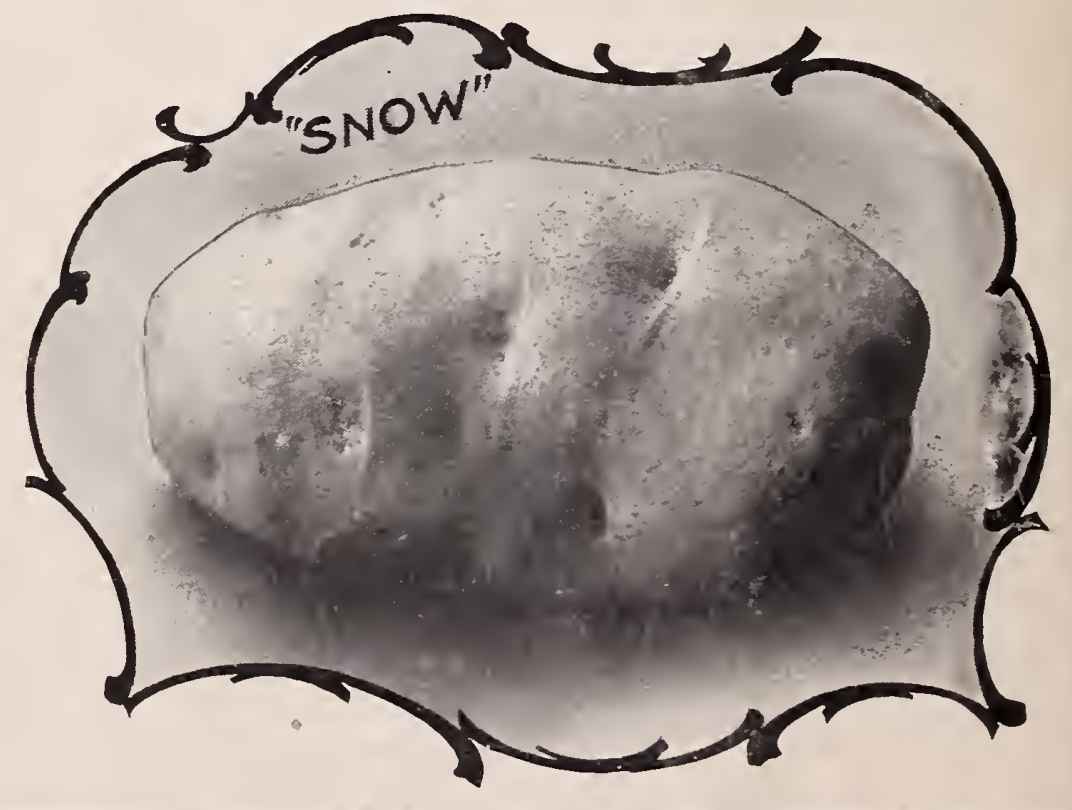

